"Effectively undermines several certainties that have characterized our thinking about the history of labor relations worldwide," MARCEL VAN DER LINDEN

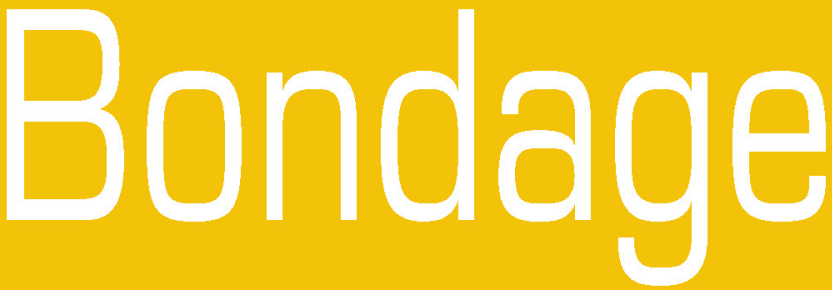

Labor and Rights in Eurasia from the Sixteenth to the Early Twentieth Centuries

\title{
Alessandro Stanziani
}


This open access library edition is supported by Knowledge Unlatched. Not for resale. 
Bondage

This open access library edition is supported by Knowledge Unlatched. Not for resale. 


\section{International Studies in Social History}

GeneralEditor: Marcelvan der Linden, International Institute of Social History, Amsterdam

Volume 1

Trade Unions, Immigration and Immigrants in Europe 1960-1993

Edited by Rinus Penninx and Judith Roosblad

\section{Volume 2}

Class and Other Identities

Edited by Lex Heerma van Voss and Marcel van der Linden

\section{Volume 3}

Rebellious Families

Edited by Jan Kok

\section{Volume 4}

Experiencing Wages

Edited by Peter Scholliers and Leonard Schwarz

Volume 5

The Imaginary Revolution

Michael Seidman

\section{Volume 6}

Revolution and Counterrevolution

Kevin Murphy

\section{Volume 7}

Miners and the State in the Ottoman Empire

Donald Quataert

\section{Volume 8}

Anarchism, Revolution and Reaction

Angel Smith

\section{Volume 9}

Sugarlandia Revisited

Edited by Ulbe Bosma, Juan

Giusti-Cordero and G. Roger Knight

\section{Volume 10}

Alternative Exchanges

Edited by Laurence Fontaine

\section{Volume 11}

A Social History of Spanish Labour

Edited by José Piqueras and Vicent Sanz-Rozalén

\section{Volume 12}

Learning on the Shop Floor

Edited by Bert De Munck,

Steven L. Kaplan and Hugo Soly

Volume 13

Unruly Masses

Wolfgang Maderthaner and Lutz Musner

\section{Volume 14}

Central European Crossroads

Pieter C. van Duin

\section{Volume 15}

Supervision and Authority in Industry

Edited by Patricia Van den Eeckhout
Volume 16

Forging Political Identity

Keith Mann

Volume 17

Gendered Money

Pernilla Jonsson and Silke Neunsinger

Volume 18

Postcolonial Migrants and Identity Politics

Edited by Ulbe Bosma, Jan Lucassen, and Gert Oostindie

Volume 19

Charismatic Leadership and

Social Movements

Edited by Jan Willem Stutje

Volume 20

Maternalism Reconsidered

Edited by Marian van der Klein, Rebecca Jo

Plant, Nichole Sanders and Lori R. Weintrob

Volume 21

Routes into the Abyss

Edited by Helmut Konrad and Wolfgang

Maderthaner

Volume 22

Alienating Labour

Eszter Bartha

Volume 23

Migration, Settlement and Belonging in Europe, 1500-1930s

Edited by Steven King and Anne Winter

Volume 24

Bondage

Alessandro Stanziani

Volume 25

Bread from the Lion's Mouth: Artisans

Struggling for a Livelihood in Ottoman Cities Edited by Suraiya Faroqhi

Volume 26

The History of Labour Intermediation:

Institutions and Finding Employment in the

Nineteenth and Early Twentieth Centuries

Edited by Sigrid Wadauer, Thomas Buchner, and Alexander Mejstrik

Volume 27

Rescuing the Vulnerable: Poverty, Welfare and Social Ties in Modern Europe

Edited by Beate Althammer, Lutz Raphael, and Tamara Stazic-Wendt 


\title{
BondAge
}

\author{
Labor and Rights in Eurasia from the \\ Sixteenth to the Early Twentieth Centuries
}

Alessandro Stanziani

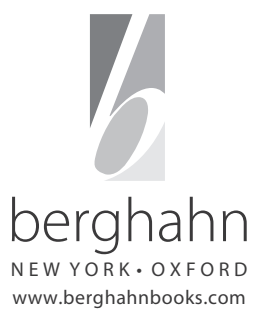

This open access library edition is supported by Knowledge Unlatched. Not for resale. 


\author{
Published in 2014 by \\ Berghahn Books \\ www.berghahnbooks.com
}

(C) 2014, 2016, 2018 Alessandro Stanziani
First paperback edition published in 2016
Open access ebook edition published in 2018

All rights reserved. Except for the quotation of short passages for the purposes of criticism and review, no part of this book may be reproduced in any form or by any means, electronic or mechanical, including photocopying, recording, or any information

storage and retrieval system now known or to be invented, without written permission of the publisher.

\title{
Library of Congress Cataloging-in-Publication Data
}

Stanziani, Alessandro.

Bondage : labor and rights in Eurasia from the sixteenth to the early twentieth centuries / Alessandro Stanziani.

pages $\mathrm{cm}$. - (International studies in social history ; volume 24)

Includes bibliographical references and index.

ISBN 978-1-78238-250-8 (hardback) - ISBN 978-1-78533-035-3 (paperback)

- ISBN 978-1-78533-660-7 (open access ebook)

1. Forced labor-Eurasia-History. 2. Slave labor-Eurasia-History.

3. Labor-Eurasia-History. I. Title.

HD4875.E83S73 2014

$331.095^{\prime} 0903-\mathrm{dc} 23$

\section{British Library Cataloguing in Publication Data}

A catalogue record for this book is available from the British Library

ISBN: 978-1-78238-250-8 hardback

ISBN: 978-1-78533-035-3 paperback

ISBN: 978-1-78533-660-7 open access ebook 


\section{Contents}

Acknowledgments $\quad$ ix

Introduction 1

The Scope and Main Argument of this Book 1

The Legal Status and Rights of Labor in Russia and Europe 2

Serfdom in a Comparative Perspective $\quad 8$

Global, Local, Imperial: Scales of Analysis 13

\section{Part I. Bondage Imagined}

1 Second Serfdom and Wage Earners in European and Russian Thought from the Enlightenment to the Mid-nineteenth Century

The Eighteenth Century: Forced Labor between Reform and Revolution

Enlightenment and Serfdom in Russia

The Proletarians Are the Real Serfs: Utopian Socialism, Christian Socialism, and Radical Thought

Conclusion

2 Poor Laws, Management, and Labor Control in Russia and Britain, or the History of the Bentham Brothers in Russia

A Global History of Labor Control: The Case of the Bentham Brothers in Russia

Estate Organization in Russia: Instruktsiia, or How to Supervise the Supervisor

Controlling Labor: Paupers and Servants in Britain

The Fate of Bentham's Panopticon: Labor Organization in

Nineteenth-century Britain and Russia

Conclusion 


\section{Part II. The Architecture of Bondage: Slaves and Serfs in Central Asia and Russia}

3 Slavery and Bondage in Central Asia and Russia from the Fourteenth to the Nineteenth Century

Introduction

Kholopy: Slaves, Serfs, or Indentured Servants? 68

War Captives at a Crossroads of Empires $\quad 75$

Slavery in Central Eurasia: Its Estimation and Overall Interpretation

4 The Institutions of Serfdom 101

Property Rules and the Legal Status of Russian Peasantry 102

Changing Legal Status: Administrative Procedure or $\begin{array}{ll}\text { Court Proceedings } & 107\end{array}$

Peasants in Town 113

Conclusion: Legal Status and Economic Dynamism in Imperial Russia

5 Labor and Dependence on Russian Estates 127

Introduction 127

Proto-industry, Trade, and Growth in the Eighteenth Century 128

From Peasant-masters to Peasant-workers? (1800-1861) 132

Toward a Reassessment of Second Serfdom in Eastern Europe $\quad 137$

\section{Part III. Old Bondage, New Practices:}

A Comparative View of the Russian, European, and Indian Ocean Worlds

6 The Persistent Servant: Labor, Rules, and Social

Hierarchies in France and Britain from the Seventeenth

to the Nineteenth Century

Labor Constraints in England 148

A French Exception? 159

Conclusion 164

7 Bondage across the Ocean:

Indentured Labor in the Indian Ocean $\quad 175$

The Main Argument $\quad 175$

Forms of Bondage in the Indian Ocean 176

Forced Migration Across the Oceans: Convicts 179

The Invention of Engagisme 181 
Engagés from Asia and Africa in the Indian Ocean in the

Eighteenth and Nineteenth Centuries

183

Engagisme after Slavery

186

From Servants to Indentured Immigrants: The Case of Mauritius

Toward a New World?

Conclusion. The Collapse and Resurgence of Bondage

Collective Bargaining and the "New" Labor Contract in Western Countries

Population, Migration, and Labor, 1870-1914 208

Russian Growth: From Serfdom to Bondage?

References

Archives

Printed Documents

Selected Bibliography

Index 
This open access library edition is supported by Knowledge Unlatched. Not for resale. 


\section{ACKNOWLEDGMENTS}

This book is the final step of long-term research and discussions with many friends and colleagues. I would like to express my gratitude to the French Agency for Research (ANR), which provided funds for my archival researches in the Indian Ocean. The Wissenschafts Kolleg in Berlin supported the editing and provided the best environment in which to complete the final version. I am particularly indebted to the rector, Luca Giuliani. In France, the EHESS (Ecole des Hautes Etudes en Sciences Sociales) and the CNRS (Centre National des Rercherches Scientifiques) provided funds and material support for my research.

Among my colleagues, I have benefited from the discussions with my very best friends Prabhu Mohapatra (Delhi University), Jane Burbank and Fred Cooper (NYU), and Marcel van der Linden (IISG, Amsterdam). I have also "exploited" Kimitaka Matsusato (Sapporo University), Kaoru Sugihara (Tokyo University), Takeo Suzuki (Waseda University), Haneda Masaki (Tokyo University), Gwyn Campbell (McGill University), Elise Kimerling Wirtschafter (Pomona University), Kenneth Pomeranz (Chicago University), Jürgen Kocka and Andreas Eckart (Re-work, Humboldt University), William Gervase Clarence-Smith (SOAS, London), Leon Fink (University of Illinois at Chicago), Gareth Austin (Graduate Institute, Geneva), Ravi Ahuja (University of Goettingen), Marina Mogilner and Ilya Guerasimov (Ab Imperio, Kazan), and Peter Holquist (University of Pennsylvania).

Finally, I want to express all my gratitude to my partner, Valentina Carbone, and my daughter Ella, for their patience during my far-too-long and far-too-deep involvement in this project. 
This open access library edition is supported by Knowledge Unlatched. Not for resale. 


\section{INTRODUCTION}

\section{The Scope and Main Argument of This Book}

This book is about the evolution of labor and labor institutions in Russia as compared with Europe, Central Asia, and the Indian Ocean region, between the sixteenth and early twentieth centuries. It questions common ideas about the origin of labor institutions and market economies-their evolution and transformation in the early-modern and modern world. Since the eighteenth century, comparative analyses of labor institutions and labor conditions in Russia have been developed as if the boundary between free and unfree labor were universally defined, and thus free labor in the West is frequently contrasted with serf labor in Russia and Eastern Europe. This book intends to call that view into question and show that Russian peasants were much less bound and unfree than usually held. Furthermore, this book also shows that in most Western countries labor was similar to service, and wage conditions resembled those of domestic servants, with numerous constraints imposed on work mobility. In colonies, this situation then gave rise to extreme forms of dependency, not only under slavery, but after it, as well (e.g., indentured labor in the Indian Ocean region and obligatory labor in Africa).

Unfree labor and forms of coercion were perfectly compatible with market development-economic growth between the seventeenth and the mid-nineteenth century in Russia, Europe, and the Indian Ocean region was achieved through the wide use of bondage and legal constraints on labor. This was not so because the population was somehow lacking, but because consistent economic growth took place throughout Eurasia at that time. The growth was labor intensive: family units, landlords, estate owners, proto-industrial and manufacturing employers, and state and public administrations all required labor. The world of bonded 
labor did not collapse with the French Revolution or the British Industrial Revolution, but only with the second Industrial Revolution and the rise of the welfare state, between 1870 and 1914. During this time, free contracts gave working people real rights, which emerged in response to the strength of unions, political turmoil, and welfare. Yet this process involved only a minority of workers in the West (mainly workers in large units), while small units, agriculture, and, above all, the European colonies were only marginally affected until the mid-twentieth century at the earliest. Twentieth-century Russia also departed from the Western path, and the "great transformation" there was ultimately achieved through new forms of bondage.

\section{The Legal Status and Rights of Labor in Russia and Europe}

From the eighteenth century to our own time, comparisons between the economies of Russia and the major Western European countries have formed part of a wider debate about the term backwardness. The goal of such debates has been to create a comparative scale that accounts for both economic growth and so-called blockages. Such comparisons have often highlighted the nature of labor, which has been categorized as "free" in the West and "forced" in Russia and Eastern Europe. Free labor is said to form the basis of capitalist economic growth, whereas forced labor is said to explain the economic backwardness of Russia. ${ }^{1}$

The recrudescence of corvée in Eastern Europe and Russia from the seventeenth through the nineteenth centuries (the so-called second serfdom) is usually explained by the increased interest devoted by local landlords to the rising international market for wheat, mostly pumped up by Western European demand and population growth. Liberal, radical, and Marxist historiography and such different authors as Kula, Wallerstein, and North agree on this: in early modern times, Eastern Europe responded to the commercial, agrarian, and, then, the industrial expansion of the West by binding the peasantries to the land and its lords. ${ }^{2}$ According to this view, the enserfment of the peasantry in the East contrasts with the rise of free wage labor in the West. These dynamics are supposed to have accompanied an increasing international division of labor in which the periphery (Asia and Africa) and quasi-periphery (Southern and Eastern Europe) became subordinate to the core (Northern and Western Europe).

The fact that very different authors agree on these arguments confirms the persistent strength of two assumptions common to liberal and Marxist historiographies: first, an ethnocentric assumption, which states that Europe and Britain are the core of modern and contemporary history, 
and, second, that there is a clear-cut and ahistorical opposition between free and unfree labor. Only on the basis of these assumptions can the overall economic dynamics of the early modern world be depicted in terms of a periphery, dependence, and the opposition between freedom and unfreedom, markets, and institutions. It is interesting that even new approaches in world history such as Pomeranz's "great divergence," while contesting China backwardness and European ethnocentrism, still consider Russia the paradigm of unfree labor and lack of markets and, as such, as the county that stands in contradistinction to both the Lower Yangtze and Britain. ${ }^{3}$

Clear-cut distinctions may be analytically useful, but they are not confirmed by an empirical analysis of the categories and practices of early-modern and modern Eurasia. This book firmly contests these issues and provides an alternative global explanation of labor, institutions, and economies of the seventeenth through the twentieth centuries. Part 1 ("Bondage Imagined") discusses the role of ideas and perceptions in shaping dependency, peripheries, and bondage, challenging both Said's Orientalism and Wallerstein's world-system approach. Chapter 1 shows that the Enlightenment invented an ideal Russian serfdom and a backward Eastern Europe opposed to the modernizing West but that this attitude was much more complex than Orientalism suggests, ${ }^{4}$ insofar as it owes much to a more general debate on forms of labor in the West. Indeed, in eighteenth-century thought, the definition of backwardness and its main element-labor-lay at the nexus of three interrelated debates: over serfdom in Eastern Europe, slavery in the colonies, and guild reform in France. I show that these debates were interrelated and that images of "the Other" were tightly linked to normative ambitions in France and Britain. During much of the eighteenth century, the attitudes of the French philosophes, economists, and travelers about forced labor (serfdom and slavery) were influenced by considerations both economic (forced labor is advantageous in certain situations) and political (reforms have to be gradual, and both owners and slaves must be educated before the system is abolished). Only in the 1780s did these positions become radicalized, in connection with the first slave revolts in Antilles. The 1780 edition of Raynal and Diderot's Histoire des deux Indes clearly incited the slaves to revolt, and a revolutionary outlook took the place of reformism. During the same years the British abolitionist movement won massive support. ${ }^{5}$

These varied attitudes toward slavery highlight a much more fundamental dilemma in French and British political philosophy about the status of labor and the role of law in relation to the economy. ${ }^{6}$ The economic rationality that issued from the French Revolution and that was further developed over the first half of the nineteenth century had trouble 
reconciling these elements. In Britain, the Glorious Revolution of 1688 and the first process of industrialization relied upon servants (not wage earners or proletarians) and the poor laws as a system of recruitment. This is why in Great Britain, even more than in Russia, moral and political arguments-rather than strictly economic ones-made the victory of abolitionism possible. It is therefore difficult to speak of a "distortion" of Enlightenment and (later) liberal philosophy by Russian economists and administrators, whose thinking was supposedly still influenced by the management of forced labor. On the contrary, Russian elites shared much of the European ambivalence about freedom and labor.

Chapter 2 integrates these views and studies the historical link between forms of surveillance and organization in labor relations in European representations. The experiences of Jeremy and Samuel Bentham in Russia, where they invented what is universally known as the Panopticon, orient my investigation. Using sources from British and Russian archives, I provide a new interpretation of the Panopticon through its Russian origins. Before and after Foucault, ${ }^{7}$ the Panopticon has been seen as a response to social deviance and has been viewed in relation to prisons and the emergence of a global surveillance system in modern societies. ${ }^{8} \mathrm{I}$ challenge this approach by arguing that the Panopticon project was actually a system for controlling wage labor that drew its inspiration from a particular image of Russian serfdom and from the Bentham brothers' experiences in that country. ${ }^{9}$ Between 1780 and 1787, Samuel and Jeremy Bentham were asked to manage a large Russian estate owned by Prince Grigorii Potemkin, one of the closest advisors of Catherine II. The problem of controlling skilled English workers in Russia (and not the Russian serfs) is what actually led the Bentham brothers to reflect on the relationship between free and forced labor - and then between labor and society. The fact that the Benthams were uncomfortable with wage labor reflects a wider attitude of the British toward the poor and the servant in the broad social order of that time. In other words, liberal approaches to labor did not invent a backward Russia (the Orientalists' approach) or new categories of "marginal people" (Foucault's argument), rather it drew inspiration from Russia to solve the long-standing problem of managing wage labor and the poor in Britain.

At the same time, one cannot take for granted the elites' representations of labor, slavery, and serfdom for implemented policies and socioeconomic dynamics. Links, convergences, and disconnections between ideas, policies, and structural dynamics need to be empirically tested. The second part of this book, "The Architecture of Bondage," contains three chapters, covering slavery and bondage in Russia and Inner Asia, the institutions of serfdom, and labor practices, respectively. Chapter 3 provides 
one of the first attempts to identify and quantify slavery and bondage in early-modern Inner Asia, between the fourteenth and the nineteenth century. It also looks for the origins of Russian serfdom and Eurasian labor institutions in the medieval and early-modern slave trade. The import of Russian, Tatar, and Central Asian slaves into the Mediterranean region is usually depicted as an early expression of colonial slavery on the one hand, ${ }^{10}$ and of Russian serfdom on the other. ${ }^{11}$ The few available studies on this topic have focused mostly on imports by Ottoman ${ }^{12}$ and European powers but have neglected Russian sources and the existence of forms of bondage and eventually slavery in Russia itself (before serfdom). I develop a fully integrated approach and mobilize Russian sources that have been poorly explored until now (including translations from Persian, Chinese, Turkish, and particularly Genoese archives). I bring together the origin of war captives and their destinations and add to this the study of local forms of bondage and slavery in Russia. I furthermore link the slave trade in Inner Asia to three major networks and routes: the eastern route, from China to the Black Sea and the Mediterranean (the Silk Road); the north-south route, from Muscovy to Persia, Afghanistan, and India; and the north-southwest route, from Muscovy to the Ottoman Empire. I also attempt to quantify this slave trade, neglected by so many historians.

Traditionally, the dismissing of kholopstvo, or limited-term slaves, has been linked to the evolution of warfare (with the increasing importance of gunpowder), to the (related) growing importance of artillery, and, therefore, to the constitution of national systems of recruitment. In Russia as elsewhere, this went along with the necessity of reforming the fiscal system. New legal constraints on labor mobility were then imposed, which have been termed as serfdom. Chapter 4 studies the rise and implementation of these new constraints. In this case, as with slavery, I begin with an analysis of words and translations. I show that until the 1840s, Russian official rules, jurisprudence, legal records, and even estate archives never spoke of "serfs" but of "peasants" and "rural population." The supposed Russian expression for serfdom emerged only in the years before the so-called abolition of serfdom. It seems dubious to assume a collective and spontaneous censorship over centuries, so we must take these sources seriously. But if peasants were not serfs, what were they?

I would argue that they were bonded people with important limitations on mobility who were obligated to provide labor. ${ }^{13}$ Yet these measures were dictated not only by the taxation and military requirements of the rising Russian state, ${ }^{14}$ which were linked to Russian territorial expansion, ${ }^{15}$ but they also led to a significant redefinition of the relationships between social groups and the state, especially the value of land ownership as a social and political marker. Limitation of peasant mobility was 
only a consequence and a tool in this fight, not the main aim of Russian politics. ${ }^{16}$ This explains how, in contradiction to common hypotheses and despite supposed serfdom, ${ }^{17}$ archives (that until now have been poorly explored) show that peasants never stopped moving from one estate to another or from one region to another-and that the government took measures to ensure this right. In short, serfdom was an attempt to discipline the competition between estate owners, and it was a form of institutional extortion of peasants by landlords whose rights officially consisted of controlling marriages, second jobs, and emigrations. There never was a central institutionalization of serfdom in Russia, but there were local forms of bondage. ${ }^{18}$

Further confirmation of this explanation is offered by the huge number of judicial litigations between landlords, landlords and peasants, and landlords and merchants concerning peasants moving without permission or working for another landlord or merchant without paying a fee and compensation to the entitled estate owner. ${ }^{19}$ I make wide use of unexplored Russian judicial archives, which gave me access to litigation between estate owners about their titles, between peasants and estate owners about rights and obligations, and, ultimately, between the state and estate owners. I show that in the decades before the official abolition of serfdom, half of the peasantry changed its status and left the category of "private peasants," while within this last category, only half were still obliged to provide labor services. ${ }^{20}$ From this perspective, the reforms of 1861 have to be put in the broader context of several reforms implemented over a century and a half. These reforms did not mark a break, because first, serfdom did not previously exist as such, and, second, legal constraints on peasant mobility and peasant labor did not disappear after 1861 .

In order to validate these statements, we need to closely consider the interplay between legal rules and their implementation, on the one hand, and economic practices, on the other. Chapter 5 discusses the organization of labor on Russian estates in detail. It addresses the questions: Were Russian peasants obliged to provide corvées, and were corvées a major obstacle to, if not the antithesis of, market relations?

I explore estate archives and answer no to both questions. Landlords could ask peasants for quitrent or labor services (corvées). Western, as well as Russian and Soviet, historiography traditionally argues that quitrent encouraged trade and economic growth, whereas labor service restricted both. ${ }^{21}$ This argument has been widely echoed by historians of serfdom in Western ${ }^{22}$ and Eastern Europe. ${ }^{23}$ Any satisfactory answer to this question requires an assessment of labor productivity and overall demesne efficiency. The question underlying this debate is important: 
were historical forms of forced labor compatible with the market, innovation, and capitalism?

I do not intend to provide a general a priori definition of capitalism, but I rely upon its flexible architecture and practices over time. Unlike liberal approaches, I do not link capitalism to the free market and private property; as I have shown in other works ${ }^{24}$ in its historical variations capitalism can never be associated with the free market and competition, but only with different forms of regulation. Markets are the very ground of capitalism, but they are never self-regulated. Starting from this, my thinking is close to Braudel and Sombart in linking capitalism to markets, regulated exchange, and the desire for (or attempt at) imperfect competition and forms of monopoly. The practices of property and the complicated definition of what "property" and "private" are in different historical situations suggest avoiding this category to define capitalism. "Corporate governance" and "Chinese regime" are but two names of among many other examples of how complicated the definition of private property can be.

In the present book, I focus on the other side of capitalism-labor. In this case, as well, I intend to take my distance from liberal, as well as Marxist and Weberian, definitions of capitalism. Workers were not other forms of "independent producers" making a free choice; on the contrary, we will see that this association between a worker and an independent artisan was used in nineteenth-century French law to settle a peculiar form of labor market. It was an institutional construction, and there was no free choice by the actors themselves.

I also intend to show that capitalism cannot be associated with wage labor and "proletarians": first, because proletarians and wage earners became dominant actors only with the second Industrial Revolution, while during the previous centuries - the ones we study here-peasant workers and servants were the leading actors. The second reason I exclude any identification of capitalism with free labor is that "time on the cross" in American slavery and many other regimes up through today's global economies are considered expressions of capitalism, despite the more or less massive presence of unfree labor. I prove this link by studying intermediate forms between chattel slavery and wage earners, that is: serfs, servants, indentured immigrants, and rural laborers. I show that these actors were not marginal, but rather they were central in the global economic and social dynamics between the seventeenth and mid-nineteenth centuries.

The chapter further demonstrates that not only were the "agency" problems on Russian estates solved on the basis of abstract economic considerations, but that these considerations responded to the peculiar way 
institutions and actors interacted. Peasants' leaders, landlords, and bailiffs were much more in coordination with than in opposition to each other. The attention given to supervision and its organization testifies to the role of intermediary institutions (bailiffs and village elders) and their ability to complement each other. Starting from this, I conclude that there is no evidence for Kula's and Wallerstein's models. According to them, under the second serfdom, Russian demesnes reduced their integration in local markets; peasants became self-sufficient; and landlords extracted a surplus of cereals from the peasants and then sold it mostly abroad and used the income not to invest, but to buy luxury products. In this view, Russian and Eastern European serfdom constituted a contribution from the supposedly backward Russia to the industrializing "advanced" Europe. Instead, I show that an increasing integration of Russian local markets into a national market occurred during the second half of the eighteenth century, when not only landlords, but their peasants, firmly entered the rural agrarian markets. Peasant activity on rural markets even surpassed that of merchants and small urban traders. Therefore, contrary to the traditional arguments, the trade in estate production increased with barshchina (corvées), which was compatible not only with exportation and long distances, but with the rise of local and national markets, as well.

\section{Serfdom in a Comparative Perspective}

The conclusions this book reaches for Russia are quite similar to those recently advanced for Eastern Europe agriculture under serfdom. As in Russia, seigniorial regulation in many Central and Eastern European areas aimed at integrating subject proto-industries into the system of demesne economy. ${ }^{25}$ The peasant economy under serfdom corresponded neither to the Chayanovian nor Kula model. Russia and Eastern Europe were not the periphery and quasi-periphery of Western Europe. The case of Russia testifies to a different path on which peasants and noble estate owners took control of agrarian and proto-industrial markets. If this is true, then, is it still correct to associate serfdom with slavery and oppose it to wage labor?

The third part of this book ("Old Bondage, New Practices: A Comparative View") consists of two chapters that put the institutions and practices of Russian serfdom into an entangled and comparative perspective. I attempt here to escape the usual comparisons between wage labor, serfdom, and slavery made on the basis of ideal types rather than historical realities. Conventional approaches provide an ideal definition of each term. Thus slavery and serfdom are defined by the lack of legal rights allotted to slaves and serfs, their hereditary statute, the master's right of ownership, and the coercive extraction of surplus. The major identified 
difference is that unlike slaves, serfs were attached to the land. ${ }^{26}$ This distinction oriented Kolchin's well-known comparison between American slavery and Russian serfdom. ${ }^{27}$

I adopt a different methodological assumption: rather than comparing ideal types, I examine historical forms of wage labor, serfdom, and slavery. Confino already criticized Kolchin's book for its reliance on a peculiar model, namely, Wallerstein's world economy, in which Russia and the United States are the peripheries of Europe. To this end, according to Confino, Kolchin deliberately ignored important differences between American slavery and Russian serfdom: to start with, the fact that Russian serfs did not come from distant countries and did not belong to a different ethnic group. Thus the master-slave relationship did not find an equivalent in Russia, where the peasant commune and its elders mediated the relationship between the estate owner and the peasants. The Russian master was therefore much more obliged to negotiate peasants' services than was the American slave owner. ${ }^{28}$

I further develop this argument. The difference between American slavery and Russian serfdom was even greater than Confino and others (Steven Hoch, for example) have stressed. This issue stands upon two main arguments: on the one hand, the circulation of knowledge and practices between Russia, Inner Asia, and Europe (as discussed in chapters 1,2 , and 3 ) provides a solid ground for entangled historical dynamics and strongly supports the thesis of a commonality of values, notions, and practices in all these areas. On the other hand, as I demonstrate in chapters 4 and 5, unlike American slaves, ${ }^{29}$ Russian peasants constantly brought judicial litigations and developed their own economic activity (they merely had to pay fees to their masters). Most important, the steppe was colonized (with a million people moving) in the seventeenth and eighteenth centuries, and Siberia was colonized in the eighteenth and early nineteenth centuries, before the official abolition of serfdom. It is as if American slaves had colonized the western frontier before 1865. In short, it makes no sense to consider American slavery and Russian serfdom to be similar institutions. The Cold War is over, and one need not find in the Russian past an equivalent of American slavery.

Instead, I suggest that revisiting Russian serfdom constitutes a powerful heuristic to discuss wage labor in Europe and forms of bondage in the Afro-Eurasian space. In particular, chapter 6 shows that from the sixteenth to the nineteenth centuries, rules on runaways were adopted not only in Russia and for slaves and indentured workers in the colonies, but also in Great Britain, where fugitive workers, journeymen, and servants in general were submitted to severe criminal punishment under the Master and Servant Acts. Apprenticeship, advances in wages and raw materials, 
and also simple master-servant relations were adduced to justify such provisions. From the sixteenth to the end of the nineteenth century in Britain and Europe, free labor, even where a contract existed, was considered the property of the employer and a resource for the whole community to which the individual belonged. ${ }^{30}$ In Britain, punitive measures accompanied the emphasis placed on contractual free will as a foundation of the labor market. Punitive sanctions in text rules and their implementation increased in the eighteenth and nineteenth centuries. Thus the long-term movement of labor and its rules in Great Britain hardly confirm the traditional argument that early labor freedom in the country supported the Industrial Revolution. On the contrary, the Industrial Revolution was accompanied by subjecting workers to increasingly tough regulations and punitive sanctions. Increasing legal constraints on labor-not increasing free wage labor-went hand in hand with the Industrial Revolution. ${ }^{31}$

France presents quite a similar story: the notion of a work contract, and hence that of a "wage earner" as we know it today, did not exist until the end of the nineteenth century. Before that, although the French Revolution suppressed lifetime engagement, it did not abolish the notion of labor as service. ${ }^{32}$

Of course, institutional dynamics do not tell the whole story. Practices changed over time, and labor contracts, mobility, and organizations evolved throughout the studied period; however, the interplay between rules and practices on the one hand, and between Britain, France, and Russia on the other, causes such conventional breaks as "before and after the Industrial Revolution" and "before and after the French Revolution" to be outmoded. Continuities, not only changes, are important and deserve explanation.

Let us be clear: I do not mean that French or British workers were serfs or that they were the same as Russian peasants. I simply argue that the gap between Russian serfdom and European wage labor is narrower than is usually held and that these were not opposite worlds testifying to the conflict between freedom and unfreedom, but rather two poles of a common world in which masters (not employers!) had far greater rights than servants, working people, and peasants. As such, Russian bondage was one (extreme) expression of a wider notion of labor as service.

These connections look even stronger when one includes European colonies in the overall picture. Indeed, the notions and practices of wage labor in Europe intersected not only with those of serfdom in Russia, but also, and above all, with the evolution of these same notions and practices of labor in the colonies. The gap between Russia and Western Europe closes further when one considers European practices in the colonies. Chapter 7 examines the interrelation between slavery, its abolition, 
and post-emancipation forms of labor in a particular context, that of the Indian Ocean. First of all, like the steppe and the Eurasian world studied in chapter 3, the Indian Ocean region constituted a type of overall economy well before the Atlantic Ocean region did. The slave trade in the Indian Ocean was also multidirectional; over time, its direction and principal destinations changed, and it involved not only men, but women, as well. The forms of slavery were therefore multiple and varied-there were palace slaves, soldier slaves, female and child slaves, and slave laborers in agriculture and manufacturing, with diverse statuses. ${ }^{33}$ From this point of view, as with slavery in Inner Asia and serfdom in Russia, the meaning of slavery in the Indian Ocean region only becomes intelligible when viewed outside the categories of ancient or North American slavery. It often entailed mutual forms of dependence in which one individual (or a group or caste) of inferior status was under obligation to another with superior status, who in turn was under obligation to a superior. The forms of status obligation, bondage, and temporary slavery (for debt, etc.) coexisted with forms of hereditary slavery similar to that in North America. ${ }^{34}$ The interaction among the forms of bondage and the notions of indentured labor and its French equivalent (called engagisme exported by the Europeans make this an interesting case..$^{35} \mathrm{My}$ argument states that it would have been impossible to develop the indenture contract in the British Empire if the British wage earner had not been a servant, subject to the multiple Master and Servant Acts. Similarly, the engagés (equivalent to indentured servants) and bonded laborers in the French colonies would have been inconceivable had there been no hiring for services and domestic service in France. Over the long term, there was interaction within this complex world: the conditions and legal status of servants and indentured people in the colonies and those of wage earners in France and Great Britain influenced each other.

This argument wishes to overcome the two leading interpretations of the history of wage and indentured labor. According to a first approach, the indentured contract resembled forced labor and slavery, and contracts were expressed as legal fiction. ${ }^{36}$ Such an approach deprives the abolition of slavery of any historical significance ${ }^{37}$ while neglecting all the efforts indentured immigrants made to fight for their own rights.

Several legal scholars have opposed this view by demonstrating that the indenture contract was not considered an expression of forced labor until the second half of the nineteenth century, whereas until that date, it was viewed as an expression of free will in contract. ${ }^{38}$ This argument joins recent trends in the history of emigration that also stress the shifting boundary between free and unfree emigration. ${ }^{39}$ I develop this last view and add a further dimension to it, namely, the link between the 
evolution of forms of labor in Europe and in its colonies. I add that all these actors (masters, servants, daily laborers, indentured immigrants) belonged to one and the same world, which comprised legal inequalities between employers (masters) and workers (servants). Within this common world, inequalities between the legal and economic entitlements of working people and those of their masters were far greater in the colonies than in Europe and also differed between colonies of the same empire, as well as between European countries and between different areas of a given country.

On this basis, I examine the relations between Europe and its colonies in a more complex way than the simple dependence of the latter on the former would suggest. I claim the necessity of avoiding any simplistic identification of colonial discourse with colonial practices. Colonial elites expressed quite complex and often divergent aims, which were all the more difficult to translate into practice, as colonized people were far from being merely passive recipients. These arguments are based on the rich sources of the archives in London (Kew), Aix-en-Province (French colonial archives), and in Mauritius and Reunion Island.

To sum up, between the sixteenth and the nineteenth centuries, forms of bondage and legal constraints were widespread throughout Europe, Russia, Inner Asia, Africa, and the Indian Ocean region. Working people had fewer rights than their employer-masters or estate owners (and sometimes had none). This common world responded to the stabilization of elites and territorial powers, but it also responded to the rise of markets and the market economy. There were important reciprocal influences and a circulation of knowledge, institutions, and practices between Russia and Inner Asia, Russia and Europe, Europe and Islam, Europe and its colonies, and Europe and local powers in Asia and Africa. The so-called commercial, agrarian, and then Industrial Revolutions did not break this world, but enhanced it. This could be so because the process was far from revolutionary: it was part of a long-term evolution, ${ }^{40}$ and it was not limited to the West. The presumed Western domination (so important in the world-system and dependency theories) does not find confirmation first in central Eurasia and the western Mediterranean in the sixteenth through eighteenth centuries, then in eighteenth- and nineteenth-century Eastern Europe and Russia, and finally in the eighteenth- through twentieth-century Indian Ocean region. We will see that these areas were not just the West's dominated peripheries of the West, but active players on the local and international chessboard.

The book's final chapter draws wider implications: it announces the decline of the global world of labor and bondage as studied in the preceding chapters. This world reflected and supported the labor-intensive 
growth in Eurasia between the seventeenth and the nineteenth centuries. The repeal of the Master and Servant Acts (1875), the invention of the "new" labor contract of employment in Britain, France, and most of the Western countries between the 1890s and 1914, the abolition of serfdom in Russia (1861), of slavery in the United States (1865), and ultimately of slavery in French Africa (1904-5) and indenture contract in India (1916), together marked the attempt to put an end to a labor world made up of unequal status and rights between enserfed servants and bonded people on the one hand, and their masters on the other hand. I link this major shift in the history of labor to a set of forces: the rise of the first welfare state, the second Industrial Revolution, the legalization of trade unions and the extension of political rights in Europe, and the evolution of labor in the colonies. ${ }^{41}$

At the same time, this process took different forms in different places; even in the West, the first welfare state (between the 1890s and 1945) benefited only a minority of workers, mostly those in large industries, while small units and agriculture stood outside this evolution. Also, in the colonies, the decline of the indenture contracts took several decades and interacted with the expansion of free emigration, decreasing costs of transportation, and mechanization. New forms of forced labor developed, in particular in Africa, where the official abolition of local slavery sustained new disguised forms of coerced labor. ${ }^{42}$ Even worse, Europe renewed bondage under Nazism and Soviet Communism.

\section{Global, Local, Imperial: Scales of Analysis}

Between the seventeenth and mid-nineteenth centuries, continuities and links between free and unfree labor prevailed over clear-cut oppositions, such as those between wage earners and serfs and indentured immigrants and servants, in time as well as in space. Thus the historical dynamics of labor must be understood both in a global dimension and in local specificities. Imperial, national, regional, and local features should be taken into consideration in order to understand how the whole system worked. From this perspective, two main variables are worthy of mention: the circulation of economic and legal knowledge and economic and institutional dynamics between the seventeenth and twentieth centuries. Economic knowledge and legal models circulated along with people and goods. This circulation led not only to increased homogeneity among systems, but also to differentiation and even hierarchies of areas and countries. The advances of the Enlightenment therefore contributed to the invention of a historiographical break between "enlightened France" and the old France, as well as between Western and Eastern Europe. 
At the same time, the circulation of ideas and models is important, but it cannot be taken exclusively as a synonym for dependency, because the center and its peripheries often influenced each other; bondage and slavery did, in fact, exist, although in different forms, before and after colonization; and finally, emancipation did not come about solely under pressure exerted by the "advanced West." The role of the circulation of knowledge is bound up with economic and social trends as a whole-but on what scale?

This book focuses on Eurasia for a number of reasons. First of all, because studies of the evolution of labor in Western Europe has been excessively dominated by a Eurocentric approach that views the Industrial Revolution and the French Revolution as the major breaks. I would like to show that these turning points were merely partial as far as labor institutions were concerned and that the dynamics at work in France, England, Russia, and Europe in general can be grasped only in their interaction with other parts of the world. Researchers, especially in the last few years, have written at length about the interaction between Europe and the Americas and between Europe and Africa, whereas the relationships between Europe and Asia have received less attention. Examining Europe, Russia, Inner Asia, and some European colonies in the Indian Ocean together has the advantage of avoiding retrospective thinking about Europe; labor institutions and practices in Europe were connected to what was happening in its colonies and in Asian empires. The choices of main areas-Russia, France, Britain, Mauritius, and Reunion Islands (and within each area, some specific regions and estates) - has been made not because these regions are statistically representative, but because they are especially relevant to the questions we are asking. Thus the Russian Empire is interesting not because it is "the land of despotism," but because new data reveal considerable economic and demographic growth at the time of serfdom. Russia will no longer be viewed as an ideological ideal type-land of despotism, land of serfdom - but a real object of historical analysis. Indeed, once second serfdom has recovered its place within the comparative history of forms of labor, we will take another look at the differences from and similarities to other possible configurations of the labor world. The French case is of interest not because it was the land of Colbertism and opposed to liberal England or because nineteenth-century France was the country of free, codified law as compared with Germany, which still lagged behind. On the contrary, France is of interest because its labor norms in the nineteenth century were actually quite well suited both to a capitalist economy and to the heritage of the Old Regime. Highlighting the case of France and comparing it with England leads us to question the differences between liberalism and regulationism-or 
between free labor and guilds within the capitalist world-and from there to narrow the distance separating free labor from the varieties of bondage. Contrary to a widespread preconception, common law in England was in fact accompanied by a considerable degree of regulation and state intervention, and labor remained subject to punitive constraints until the end of the nineteenth century.

Among the Western colonies, I have paid special attention to Mauritius and Réunion Island, because the time is ripe for a new analysis of the forms of dependence in the French and British Empires based specifically on labor status. While British and French norms and perceptions translated into various forms of bondage in the Indian Ocean region, thereby helping perpetuate slavery well after its official abolition, slavery nevertheless existed prior to any European intervention. The adopted solution did not result solely from British and French influences, but rather from interaction between those influences and local traditions.

These comparisons on the national and imperial level are valid only as a rough approximation. No doubt, legal rules (civil, tax, and customs laws) refer to the national and imperial dimension of these phenomena; yet those rules were only one component of economic action, along with symbolic, cultural, and political aspects. Hence we cannot ignore the importance of local components and the great differences between the dynamics of different regions. Forms of labor varied from one city to the next and from one place to another. This observation is especially relevant in our case, as the institutions and economic activities of the world we are studying were extremely fluid, multiple, and local, from the eighteenth to the early twentieth centuries. Several institutions coexisted on the local level, and even when a process of national unification took place, institutional pluralism continued. Institutional pluralism was more widespread on the level of empires, where legal pluralism was an important instrument of economic and political action. ${ }^{43}$

Local practices and customs also played an important role, and they were recognized in nineteenth-century Russia with regard to property; these elements account simultaneously for common phenomena (restrictions on labor mobility), the diverse ways they were expressed, and their source (worker's booklet, Russian serfdom, legal punishment in the British Empire). They also explain the differences between the dynamics of Lancashire, the south of France, and western Russia, as well as those between individual areas of England or the Russian steppe. Different solutions were adopted within a few miles of each other, and similarities developed more frequently with estates in distant regions than with those nearby. The labor rules and practices that were ultimately adopted testify to local irreducibility within a space that was, nevertheless, global. 


\section{Notes}

1. Jerome Blum, Lord and Peasant in Russia from the Ninth to the Nineteenth Century (New York: Atheneum, 1964); Alexander Gerschenkron, Economic Backwardness in Historical Perspective: A Book of Essays (Cambridge, MA: Belknap Press of Harvard University Press, 1962); Olga Crisp, Studies in the Russian Economy Before 1914 (London: Macmillan, 1976); Roger Portal, "The Industrialization of Russia," in The Cambridge Economic History of Europe, ed. Hrothgar J. Habakkuk and Michael M. Postan (Cambridge: Cambridge University Press, 1978), v. 6, pt. 2.

2. Immanuel Wallerstein, The Modern World-System: Capitalist Agriculture and the Origins of the European World-Economy in the Sixteenth Century (New York, London: Atheneum, 1974,1976); Witold Kula, An Economic Theory of the Feudal System (London: New Left Books, 1976); Douglass North, Structure and Change in Economic History (New York: Norton, 1981).

3. Kenneth Pomeranz, The Great Divergence (Princeton: Princeton University Press, 2000).

4. Larry Wolff, Inventing Eastern Europe: The Map of Civilization on the Mind of the Enlightenment (Stanford: Stanford University Press, 1994). Wolff's book is the best expression of the attempt to apply Said's argument to Eastern Europe.

5. Seymour Drescher, Capitalism and Antislavery (New York: Oxford University Press, 1987); David Brion Davis, The Problem of Slavery in the Age of Revolution, 1770-1823 (New York: Oxford University Press, 1999); Robert Blackburn, The Overthrow of Colonial Slavery, 1776-1848 (London: Verso, 1988).

6. Alessandro Stanziani, "Free Labor-Forced Labor: An Uncertain Boundary? The Circulation of Economic Ideas between Russia and Europe from the Eighteenth to the Mid-nineteenth Century," Kritika: Explorations in Russian and Eurasian History 9, 1 (2008): 1-27.

7. Michel Foucault, Discipline and Punish: The Birth of the Prison (Paris, 1975, and in English translation, by A. Sheridan for Harmondsworth, 1985). The identification of Foucault's understanding of the Panopticon solely in terms of surveillance has recently been challenged by Anne Brunon-Ernst, in "When Foucault Reads Bentham," paper presented at the Annual Meeting of the Law and Society Association, Berlin, 25 July 2007, http:// www.allacademic.com/meta/p178059_index.html.

8. Let me provide just a few references from the huge bibliography on Foucault and his interpretation of the Panopticon: Alain McKinlay and Ken Starkey, eds., Foucault, Management and Organization Theory: From Panopticon to Technologies of Self (London: Sage Publications, 1998); Janet Semple, "Foucault and Bentham: A Defence of Panopticism," Utilitas 4, l (1992): 105-20; Jean-Yves Grenier and André Orléan, "Michel Foucault, L'économie politique et le libéralisme"” Annales HSC 5 (2007): 1155-82; Marc Abélès, Anthropologie de l'Etat (Paris: Payot, 1990); Louise Warriar, Andrew Robert, and Jennifer Lewis, Surveillance: An Analysis of Jeremy Bentham and Michel Foucault and Their Present-day Relevance, http://www.mdx.ac.uk/WWW/STUDY/ybenfou.htm.

9. Simon Werrett, "Potemkin and the Panopticon: Samuel Bentham and the Architecture of Absolutism in Eighteenth-century Russia," The Philosophic Age Almanac 9 (1999, special issue: The Science of Morality: Jeremy Bentham and Russia): 106-35. See also Ian R. Christie, The Benthams in Russia, 1780-1791 (Oxford: Berg, 1993); Ian R. Christie, "Samuel Bentham and the Western Colony at Krichev, 1784-1787," Slavonic and East European Review 48, 111 (1970): 232-47; Simon Sebag Montefiore, "Prince Potemkin and the Benthams: The Project to Create an English Village with Modern Factories in Belorussia," History Today 52, 8 (Aug. 2003): 38-43; Simon Sebag Montefiore, Prince of Princes: The Life of Potemkin (London: Phoenix Press, 2001); Anthony G. Cross, By the Banks of the Neva: Chapters from the Lives and Careers of the British in Eighteenth-century Russia (Cambridge: Cambridge University Press, 1997); Alessandro Stanziani, "The Traveling Panopticon: 
Labor Institutions and Labor Practices in Russia and Britain in the Eighteenth and Nineteenth Centuries," Comparative Studies in Society and History 51, 4 (2009): 715-41.

10. Jacques Heers, Esclaves et domestiques au Moyen Age dans le monde méditerranéen (Paris: Hachette, 1996), 67; Charles Verlinden, "L'origine de sclavus=esclave," Bulletin du Cange, XVII (1942): 97-128; Charles Verlinden, "L'esclavage du sud-est et de l'est européen en Europe orientale à la fin du moyen-âge," Revue historique du sud-est européen, XIX (1942): 18-29; Charles Verlinden, Lesclavage dans l'Europe médiévale (Bruges: De Temple, 1955); Steven Epstein, Speaking of Slavery (Ithaca and London: Cornell University Press, 2001).

11. Richard Hellie, Slavery in Russia, 1450-1725 (Chicago: University of Chicago Press, 1982).

12. Halil Inalcik, Sources and Studies on the Ottoman Black Sea: The Custom Register of Caffa, 1487-1990 (Cambridge, MA: Harvard University Press, 1996).

13. Robert Crummey, "Sources of Boyar Power in the Seventeenth Century," Cahiers $d u$ monde russe and soviétique 34, 1-2 (1993): 107-18.

14. William C. Fuller, Strategy and Power in Russia, 1600-1914 (New York: Free Press 1992); Carol S. Leonard, Reform and Regicide: The Reign of Peter III of Russia (Bloomington: Indiana University Press, 1993).

15. Blum, Lord and Peasant; Richard Hellie, Enserfment and Military Change in Muscovy (Chicago: University of Chicago Press, 1971).

16. Henry Eaton, "Cadasters and Censuses of Muscovy," Slavic Review 26, 1 (1967): 54-69. The most complete list of published sixteenth- and seventeenth-century cadastral records appear in S.V. Voznesenskii, Materialy dlia bibliograpfii po istorii narodov SSSR XVI-XVIIvv [Materials for a bibliography of the history of the people of the USSR, the sixteenth to the seventeenth centuries] (Leningrad: Nauka, 1933).

17. Blum, Lord and the Peasant; Gerschenkron, Economic Backwardness; Crisp, Studies in the Russian Economy; Hellie, Enserfment; Peter Kolchin, Unfree Labor: American Slavery and Russian Serfdom (Cambridge, Mass: Harvard University Press 1987); Michael Bush, ed., Serfdom and Slavery: Studies in Legal Bondage (Manchester: Manchester University Press, 1996); Daniel Field, The End of Serfdom: Nobility and Bureaucracy in Russia, 1855-1861 (Cambridge, MA: Harvard University Press, 1976).

18. Steven Hoch, Serfdom and Social Control in Russia: Petrovskoe, a Village in Tambov (Chicago: Chicago University Press, 1986); David Moon, The Russian Peasantry, 1600-1930 (London: Longman, 1996).

19. Elise Kimerling Wirtschafter, Structures of Society: Imperial Russia's "People of Various Ranks" (Dekalb: Northern Illinois University Press, 1994); Elise Kimerling Wirtschafter, Social Identity in Imperial Russia (Dekalb: Northern Illinois University Press, 1997).

20. On this, see Alessandro Stanziani, "The Legal Status of Labor in the Seventeenth to the Nineteenth Century: Russia in a Comparative European Perspective," International Review of Social History 54 (2009): 359-89.

21. Blum, Lord and the Peasant.

22. Pierre Bonnassie, From Slavery to Feudalism (Cambridge: Cambridge University Press 1991); Louis Genicot, Rural Communities in the Medieval West (Baltimore: Johns Hopkins University Press, 1991); George Duby, Les trois ordres ou l'imaginaire du féodalisme (Paris: Gallimard, 1978); Tom Scott, ed., The Peasantries of Europe: From the Fourteenth to the Eighteenth Centuries (London: Longman, 1998).

23. Robert Brenner, "Agrarian Class Structure and Economic Development in Pre-industrial Europe," Past and Present 70 (1976): 30-74; Trevor Aston, Charles Philpin, eds., The Brenner Debate: Agrarian Class Structure and Economic Development in Pre-industrial Europe (Cambridge: Cambridge University Press, 1985); William Hagen, Ordinary Prussians: Brandenburg Junkers and Villagers, 1500-1840 (Cambridge: Cambridge University Press, 2002). 
24. Alessandro Stanziani, Rules of Exchange: French Capitalism in Comparative Perspective, Eighteenth to the Twentieth Centuries (Cambridge: Cambridge University Press, 2012).

25. Markus Cerman, "The Organization of Production and Trade in Proto-industrial Textile Production in Early Modern East-Central Europe: The Role of Seigniorial Influence and Sub-contracting," in Entrepreneurs and Institutions in Europe and Asia, 1500-2000, ed. Ferry de Goey and Jan Willem Veluwenkamp (Aksant: Amsterdam, 2002), 215-36.

26. For example, Bush, ed., Serfdom and Slavery, in particular "Introduction" and Stanley Engerman, "Slavery, Serfdom and Other Forms of Coerced Labor: Similarities and Differences," 18-41.

27. Kolchin, Unfree Labor.

28. Michael Confino, "Servage russe, esclavage américain," Annales ESC, 45, 5 (1990): 1119-41.

29. During the past twenty years, several researchers have stressed the divergent historical meanings and definitions of both free and unfree labor and the flexible boundaries of slavery. Bibliographical references can be found in Rebecca Scott, Thomas Holt, Frederick Cooper, and Aims McGuinness, Societies after Slavery: A Select Annotated Bibliography of Printed Sources on Cuba, Brazil, British Colonial Africa, South Africa, and the British West Indies (Pittsburgh: University of Pittsburgh Press, 2004); Rebecca Scott, "Defining the Boundaries of Freedom in the World of Cane: Cuba, Brazil, and Louisiana after Emancipation," American Historical Review 99, 1 (1994): 70-102; Joseph Calder Miller, Slavery and Slaving in World History: A Bibliography, 1900-1996 (Armonk, NY, M.E. Sharp, 1999) ; Seymour Drescher and Stanley Engerman, eds., A Historical Guide to World Slavery (New York and Oxford: Oxford University Press, 1998).

30. Robert Steinfeld, The Invention of Free Labor: The Employment Relation in English and American Law and Culture, 1350-1870 (Chapel Hill: North Carolina University Press, 1991); Michael Postan, "The Chronology of Labor Services," Transactions of the Royal Historical Society, 20 (1937): 169-93; Tom Brass and Marcel van der Linden, eds., Free and Unfree Labor: The Debate Continues (Berne: Peter Lang, 1997).

31. Steinfeld, The Invention of Free Labor; Simon Deakin and Frank Wilkinson, The Law of the Labor Market: Industrialization, Employment, and Legal Evolution (Oxford: Oxford University Press, 2005).

32. Alain Dewerpe, "En avoir ou pas. A propos du livret ouvrier dans la France du XIXe siècle," in Le travail contraint en Asie et en Europe, XVIIe-XXe siècles, ed. Alessandro Stanziani (Paris: MSH éditions, 2010), 217-40.

33. William Gervase Clarence-Smith, ed., The Economics of the Indian Ocean Slave Trade (London: Frank Cass, 1989); Gwyn Campbell, ed., The Structure of Slavery in Indian Ocean Africa and Asia (London: Frank Cass, 2004); Martin Klein, ed., Breaking the Chains: Slavery, Bondage, and Emancipation in Modern Africa and Asia (Madison: The University of Wisconsin Press, 1993); Frederick Cooper, Plantation Slavery on the East Coast of Africa (New Haven: Yale University Press, 1977).

34. James Watson, ed., Asian and African Systems of Slavery (Berkeley and Los Angeles: University of California Press, 1980); Derick Scarr, Slaving and Slavery in the Indian Ocean (London and New York: Macmillan, 1998).

35. Utsa Chakravarti, "Of Dasas and Karmakaras: Servile Labor in Ancient India," in Chains of Servitude: Bondage and Slavery in India, ed. Utsa Patnaik and M. Dingawaney (New York: Oxford University Press, 1985), 40-54; Markus Vink, "The World's Oldest Trade: Dutch Slavery in the Indian Ocean in the Seventeenth Century," Journal of World History 14, 2 (2003): 131-77.

36. Hugh Tinker, A New System of Slavery: The Export of Indian Labor Overseas, 1830-1920 (London: Hansib, 1974); Gyan Prakash, Bonded Histories: Genealogies of Labor Servitude in Colonial India (Cambridge: Cambridge University Press, 1990); Ho Hai Quang, Histoire économique de lîle de la Réunion, 1849-1881: engagisme, croissance et crise (Paris: Lavoisier, 
2004); Sudel Fuma, De l'Inde du sud à la Réunion (Port-Louis: Graphica, 1999); Sully-Santa Govindin, Les engagés indiens (Saint-Denis la Réunion: Azalées, 1994); Michèle Marimoutou, Les engagés du sucre (Saint-Denis La Réunion: Editions du tramail, 1999); Edith Wong-Hee-Kam, La diaspora chinoise aux Mascareignes: le cas de la Réunion (Paris: L'Harmattan 1996).

37. David Northrup, Indentured Labor in the Age of Imperialism, 1834-1922 (Cambridge: Cambridge University Press, 1995); Marina Carter, Servants, Sirdars, and Settlers: Indians in Mauritius, 1834-1874 (Delhi: Oxford University Press, 1995); Edmond Maestri, Esclavage et abolition dans l'Océan Indien, 1723-1860 (Paris: L'Harmattan, 2002).

38. Steinfeld, The Invention of Free Labor. On the mobile boundary between free and unfree labor, see Stanley Engerman, ed., Terms of Labor: Slavery, Serfdom, and Free Labor (Stanford: Stanford University Press, 1999); Frederick Cooper, Thomas Holt, and Rebecca Scott, Beyond Slavery: Explorations of Race, Labor, and Citizenship on Post-emancipation Societies (Chapel Hill: North Carolina University Press, 2000).

39. Jan Lucassen, Leo Lucassen, eds., Migration, Migration History, History: Old Paradigms and New Perspectives (Berne: Peter Lang, 1997); David Eltis, Coerced and Free Migration: Global Perspective (Stanford: Stanford University Press, 2002); David Galenson, White Servitude in Colonial America: An Economic Analysis (Cambridge: Cambridge University Press, 1981); Farley Grubb, "The Incidence of Servitude in Trans-Atlantic Migration, 1771-1804," Explorations in Economic History 22, 3 (1985), 316-39; Guther Paul Barth, Bitter Strength: A History of the Chinese in the United States, 1850-1870 (Cambridge, Mass.: Harvard University Press, 1964); Claude Wanquet, La France et la première abolition de l'esclavage, 1794-1802 (Paris: Karthala 1998); Christian Schnakenbourg, Histoire de l冈industrie sucrière en Guadeloupe aux XIXe et XXe siècle (Paris: L'Harmattan, 2007).

40. Charles Feinstein, "Capital Formation in Great Britain," in The Cambridge Economic History of Europe, vol. VII: The Industrial Economies: Capital, Labor and Enterprise, ed. Peter Mathias and Michael Postan (Cambridge, Cambridge University Press, 1978), $28-94$. Nicolas R. Crafts, British Economic Growth during the Industrial Revolution (Oxford: Oxford University Press 1985); Jeffrey Williamson, "Why Was British Growth So Slow during the Industrial Revolution?" The Journal of Economic History 44, 3 (1984): 687-712.

41. Deakin, Wilkinson, The Law of the Labor Market; Claude Didry, Naissance de la convention collective (Paris: EHESS, 2002); Douglas Hay and Paul Craven, eds., Masters, Servants, and Magistrates in Britain and the Empire, 1562-1955 (Chapel Hill: The University of North Carolina Press, 2004).

42. Cooper, From Slaves to Squatters. Plantation Labor and Agriculture in Coastal Kenya and Zanzibar, 1890-1925 (New Haven: Yale University Press, 1980) ; Babacar Fall, Le travail forcé en Afrique Occidentale Française 1900-1946 (Paris: Karthala, 1993); Suzanne Miers, Richard Robertseds, The End of Slavery in Africa (Madison: University of Wisconsin Press, 1988 ); François Renault, "L'abolition de l'esclavage au Sénégal. L'attitude de l'administration française 1848-1905," Revue française d'histoire d'outve-mer 58,1 (1971), 5-80.

43. Lauren Benton, Law and Colonial Culture (Cambridge: Cambridge University Press, 2002) 
This open access library edition is supported by Knowledge Unlatched. Not for resale. 
PART I

\section{BONDAGE IMAGINED}

This open access library edition is supported by Knowledge Unlatched. Not for resale. 
This open access library edition is supported by Knowledge Unlatched. Not for resale. 


\section{Second Serfoom and Wage Earners in European and Russian Thought FROM THE ENLIGHTENMENT TO THE Mid-nineteenth Century}

\section{The Eighteenth Century: Forced Labor between Reform and Revolution}

The invention of backwardness in Western economic and philosophical thought owes much to the attention given to Russia and Poland in the beginning of the eighteenth century. ${ }^{1}$ The definitions of backwardness and of labor-which is the main element of backwardness-lies at the nexus of three interrelated debates: over serfdom in Eastern European, slavery in the colonies, and guild reform in France. The connection between these three debates is what makes the definition of labor-and the distinction between free and forced labor-take on certain characteristics and not others. In the course of the eighteenth century, the work of slaves, serfs, and apprentices came to be viewed not just by ethical standards, but increasingly by its efficiency. On that basis, hierarchies were justified, such as the "backwardness" of the colonies relative to the West, of Eastern relative to Western Europe, and of France relative to England.

The chronology is striking. Criticisms of guilds, serfdom, and slavery all hardened during the 1750s; Montesquieu published The Spirit of the Laws in 1748, which was soon followed by the first volumes of the Encyclopédie. ${ }^{2}$ In these works the serfdom of absolutist and medieval Europe was contrasted with the free labor of Enlightenment Europe. Abbé de Morelli took up these themes in 1755, condemning both ancient serfdom and modern forms of slavery, in both the colonies and Russia. The advances of the Enlightenment contributed to the invention of a 
historiographical break between "enlightened France" and old France on the one hand, and between Western and Eastern Europe on the other. These two "inventions" mirror each other, e.g., in the fact that serfdom could be found in Eastern Europe as well as in medieval Europe. Eastern Europe was therefore not a special case, just simply backward on a developmental scale that was common to all countries.

At about the same time as Morelli, the physiocrat Mirabeau, in L'ami des hommes (1756-58), addressed the issue of slavery in the colonies, which he criticized in human terms as well as in terms of its profitability. ${ }^{3}$ These authors came together in the same circles and journals as Quesnay (whose Tableau économique also dates from 1758) and other physiocrats, who associated labor restrictions such as slavery and serfdom with the constraints of Old Regime regulations and guilds. ${ }^{4}$ A shared way of thinking thus developed around the status of labor: a group of authors of differing backgrounds looked into slavery in the colonies, serfdom in Russia, and guild labor in France in order to prove a "natural right" to freedom and, for some, the unprofitability of unfree forms of labor. ${ }^{5}$ This circle of reformers established a journal, the Éphémérides du citoyen, in 1766. Over time, its publications reinforced the discussion of the status of labor and the political and intellectual ties between slavery, serfdom, and guilds. As Abbé Baudeau made clear, the still-enslaved peasants and the Africans were enslaved for the same reason. ${ }^{6}$ On the other hand, this same author praised the Russian system of colonization by free settlers, which he contrasted with Western oppression in the colonies. ${ }^{7}$

Historical narrative became an increasingly common form of justification for these analogies. Thus in 1770, Anne Robert Jacques Turgotone of the leading economists of the time and future comptroller-general (i.e., finance minister of France) — who had read the accounts of travelers to Russia closely, ${ }^{8}$ likened the idea of the "serf to the land" ( $\operatorname{ser} f$ de la glèbe, the famous expression popularized by Montesquieu twenty years earlier) to the Russian serf and to the slave, in a letter to Dupont de Nemours; he even spoke of slavery to the land. In France, serfdom to the land belonged to the past. Likewise, the slave in the colonies and the Russian serf would soon become vestiges of the past, though at that time they remained justified by the backwardness of the colonies and Russia. ${ }^{9}$

Economic rhetoric was now ready to take on a major normative role. The next year, in issue 6 of Ephémérides, another physiocrat, Dupont de Nemours, calculated the economic losses that the slave inflicted on property and on the whole economy when compared with free wage labor. The normative ambitions of political economy seemed to be borne out by the interest with which enlightened monarchs in France and Russia read these works. Voltaire completed his history of Peter the Great in 
1763 and sent a copy to Catherine II. ${ }^{10}$ In this work, as in his letters to Catherine, Voltaire adopted a cautious attitude toward Russian serfdom, indicating that it would be premature to emancipate the people without first enlightening them. ${ }^{11}$

For his part, Diderot, who was flattered by Catherine's attention, wondered: "Does the servitude of the peasants not influence [their] culture? Doesn't the lack of peasant property have a negative effect?" His response was laconic: "I don't know whether there is any country where the peasant loves the soil and his home more than in Russia. Our free provinces do not have much more grain than those that are not free." 12 Diderot believed at the time in the reforming potential of Catherine and the French monarchy; based on this belief, he distinguished between nations that had already achieved their highest level of civilization and were starting to degenerate and those that remained closer to nature and could strive for a higher level of order and morals while avoiding the evils of civilization. He placed America and Russia among the latter. ${ }^{13}$

A similar movement made itself felt in France, where, in accordance with the wishes of the physiocrats, the grain regulations and hindrances to the production and trade in wheat were dismantled in 1763. In erudite circles-among the philosophes and their physiocrat friends-the feeling was that a new, reforming era had begun. This initial foray by the enlightened monarchs called for moderation in the pace of further reforms, namely the abolition of serfdom, slavery, and, finally, the guilds in France. The changes were necessary, they said, but they required time so that those affected by the changes could adjust their conduct to the new circumstances. These hopes seemed close to fulfillment when Louis XVI's ascent to the throne in 1774 brought Turgot's appointment as comptroller-general; he immediately proclaimed free trade in grain and the abolition of guilds and their jurandes (officials).

Yet the year 1774 did not mark the start of a new period of reform; instead, the preceding wave crested and began to recede. The Pugachev uprising in Russia and the protests by masters and apprentices against the abolition of the guilds in France rapidly led to a revision of the enlightened monarchs' projects, both in France and Russia. The guilds were restored in 1776, the same year that the United States declared its independence and Adam Smith published The Wealth of Nations. With slave revolts in the colonies and the end of Catherine's reforms, a new alignment of forces seemed to be taking shape. Voltaire, whose thought had been close to the thinking of the physiocrats, began to attack Necker and Quesnay, questioning the idea that economic liberty equaled justice. ${ }^{14}$

The 1780s therefore brought a radicalization of the philosophes' positions on the French monarchy, Russia, and ultimately slavery. Rather 
than trusting reforms implemented by monarchs, who were henceforth regarded as despots, it was now considered better to place one's trust in popular movements. Now radicalized philosophers celebrated the slave revolts and the 1780 edition of Raynal's Histoire des deux Indes clearly incited the slaves to revolt. A revolutionary outlook took the place of reformism.

From the 1780s on, Diderot and Condillac associated their skepticism about enlightened despotism ${ }^{15}$ with a more general criticism of European civilization. As Condillac suggested, "Too much communication with Europe was less likely to civilize [policer] the Russians than to make them adopt the vices of civilized nations." ${ }^{16}$ From this point of view, the Russian reforms called for similar reforms in France and its colonies. The majority of the philosophes held this attitude. ${ }^{17}$ As Diderot and Raynal asserted in their 1780 edition of LHistoire des deux Indes, the return of the guilds and the riots in the colonies simply bore witness to the fact that Europe had nothing to teach Russia. Rather than enlightenment, it was barbarism that was spreading, and only Great Britain and the United States seemed to be advancing in the right direction. ${ }^{18}$ The publication of the first volume of Gibbon's Decline and Fall of the Roman Empire, in 1776, and its success in France testifies to the same interest in signs of decline, not reform.

To sum up, during much of the eighteenth century, the attitudes of the French philosophes, economists, and travelers toward forced labor (serfdom and slavery) were nuanced by considerations both economic (forced labor is advantageous in certain situations) and political (reforms have to be gradual, and both owners and slaves must be educated before the system is abolished). These positions only became radicalized in the 1780s. In conjunction with this evolution, another development became apparent: the priority given to economic over political and ethical considerations, previously held only by a few physiocrats, became widespread. From that point on, more and more economists and philosophes accorded a cognitive and normative priority to pure economic calculation; however, this association came quite late and was not representative of eighteenth-century economic and philosophical thought. In contradiction to the retrospective image created from the nineteenth century on, almost all of these authors, aside from a few physiocrats, still linked economics and ethics. ${ }^{19}$

This chronology is also important, because it reveals a strong link between three objects of debate-Russia and its reforms, the colonial question, and the guilds in France. These three topics were connected because of the authors who wrote about them and the topics' intrinsic intellectual and political significance, and also because of the close 
association between economics, philosophy, and politics in the culture of the era. It was not by chance that French authors often used the words serf and slave interchangeably. The difference we recognize- that the slave can be sold without land while the serf is attached to it-is a political and historiographical construct, mostly of the nineteenth century. In the late eighteenth century, philosophers and economists conflated the two phenomena, mainly to contrast them with free labor. This construct also responded to a particular intellectual and political context, namely the question of the status of labor in France.

In light of all this, with eighteenth-century thought ultimately quite uncertain in its view of (forced) labor, one can hardly say that the Russians misinterpreted these approaches and reshaped the liberalism and enlightenment of Europe into reforms that aimed to reconcile serfdom and the market, autocracy and reform. Indeed, the question for Russia was the same as for France: Should the legal status of the serfs be abolished entirely or only modified? And furthermore, should free-market economics alone determine the political and social status quo, or should it form part of a more complex political and moral order?

\section{Enlightenment and Serfdom in Russia}

No doubt we can also see the influence of more radical, even revolutionary, thinkers on that careful reader of Raynal-Aleksandr Radishchev. ${ }^{20}$ Even so, it is worth noting that the most radical Russian approaches to serfdom often came from analyses of the American experience rather than of the French or European. ${ }^{21}$

However, because Catherine and hence the censors were reticent, even hostile, and because of the leanings of the Russian reformers and the Enlightenment philosophers who inspired them, this kind of radical outlook remained in the minority in Russia. Catherine instead encouraged her collaborators and young economists to familiarize themselves with and disseminate the ideas of the physiocrats. Mikhail Shcherbatov was not entirely wrong in claiming to be inspired by the French philosophes when he suggested keeping Peter the Great's Table of Ranks. ${ }^{22}$ Like Voltaire and Diderot in the same era, he emphasized that the peasants were not yet ready for freedom and that, under certain circumstances, serf labor was not necessarily less productive than free labor, because it protected the serf from economic and climatic hazards. Even Vasilii Tatishchev, though distant in many ways from Shcherbatov, took up the argument (dear to Enlightenment philosophy) about the education of the peasant, which, he concluded, would eliminate the threat of revolts even while ensuring a more rational organization of labor. ${ }^{23}$ 
While the heritage of the physiocrats (the notion that agriculture and large-scale farming were the driving force of the economy) and of the moderate philosophes (support for education and a partial reform of serfdom) is apparent, Shcherbatov and Catherine were also inspired by German cameralism, which spread in Russia through the intermediary of the German economists in the Academy of Sciences and at Moscow University. ${ }^{24}$ Thus August Ludwig Schlözer, in Russia since 1757 and an adjunct at the Academy of Sciences since 1762, approached his first lectures from a comparative perspective, as we can see from the questions he used as lecture titles: "How Great Is Russia in Comparison with Germany and Holland?" and "What Is a College of Justice [iustits-kollegiia]?" $25 \mathrm{He}$ advocated a partial and gradual reform of serfdom and, like the German cameralists, strongly qualified the physiocratic critique of political arithmetic, which was rightly or (more often) wrongly associated with the policies of mercantilism and absolutism. Schlözer accepted the principles of political arithmetic that had guided economic and political reforms, first in England and then in France, in the first half of the eighteenth century. The strength and wealth of a country were identified with demographic growth, and the monarchy, aided by economists and appropriate statistical tables, could support this expansion. Because political arithmetic was harnessed relatively late in Russia, as it had been in Prussia, this intellectual current did not have the same revolutionary potential as it had had in England at the start of the century, when demographic increase was connected with free labor and reforms of laws on inheritance, the transmission of goods, and the status of the nobility. ${ }^{26}$ In Russia, by contrast, a watered-down version of political arithmetic was proposed by German-born authors who sought and obtained resources to conduct statistical studies but did not connect these studies with reforms of the legal and economic system that underlay demographic changes. ${ }^{27}$

These studies became an instrument of propaganda for reforms rather than criticisms of their course. Thus, to the great pleasure of Catherine and her successors, several German and English journals published data on the Russian population, showing that the rate of infant mortality was lower in Russia than in Sweden. ${ }^{28}$ The conclusion was that Russian economic and sanitary conditions were continually improving and the reforms already begun were working. Christian Schlözer, who succeeded his father, August, at the Academy of Sciences and then at St. Petersburg University, could not have been more explicit: the well-being of a people did not lie in its wealth, nor even in its power or the extent of its empire, but in "wise laws, princes, and magistrates who respect and observe them themselves, subjects who are united with their prince and each other, active virtue and instruction. . . . It is the confluence of these 
things that results in the good use of power and wealth and in the happiness of a state." 29

At the same time, Christian Schlözer, Karl Hermann, and Wolfgang Ludwig Krafft translated Smith, whom they read in a spirit close to German cameralism. In their rendering, Smith's invisible hand looked much like the visible hand of an enlightened monarch, while the ethic that was supposed to qualify pure utilitarianism lay less in providence than in the clear rules of a society of orders. The division of labor was accepted, but only within limits imposed by serfdom and by existing technical methods, which were themselves connected with the way society was organized in both the country and the city. ${ }^{30}$ Among economists, Storch was undoubtedly the one who most violently criticized the system of slavery, and this despite his role at the University of St. Petersburg and the Academy of Sciences. A disciple of both Smith and political arithmetic, he attacked the cumbersome guild system in Europe, as well as forced labor in the colonies, Russia, and the United States. His criticism was based more on economics than morals: "Slaves have no incentive to apply themselves with zeal to labor to which they are forced; from this it follows that such labor produces very little." Moreover, he claimed, "Managing land that is cultivated by slaves involves arduous efforts and the burdensome obligation to be in residence." The problem was that "in general, slave masters are as much poor entrepreneurs as their slaves are poor workers," and he concluded, "only in Eastern Europe has the improvement of their lot been delayed by the slowness with which progress has occurred in the growth of wealth and civilization; but as these are everywhere advancing at a rapid pace, it is probable that here too, little by little, slavery and serfdom will disappear." Nevertheless, Storch opposed the immediate abolition of serfdom, which he believed would provoke riots, as well as bring about the collapse of Russia's economy and society. Instead he envisioned gradual reforms, beginning with giving the serfs more responsibility by assigning them a share of the revenues, expanding the use of obrok (quitrent) at the expense of barshchina (corvées), and, most of all, better educating the landowners about new management techniques. This process, he held, could progressively create the material and cultural conditions for emancipating the serfs. ${ }^{31}$

The sources and wide distribution of Storch's writings confirm the breadth of the debate about labor and serfdom that took place across Europe at the turn of the nineteenth century. Like the other German cameralists, Storch was not only well versed in Smith's work and an advocate of his ideas, he also drew inspiration from the reforms being undertaken in the German lands, where, as recent research shows, the evolution of serfdom had begun before the arrival of Napoleon's armies and the 
civil code. ${ }^{32}$ Storch argued that appropriately modified legal rules could support these transformations of serfdom. In this belief he was inspired by the monumental work of the Brandenburg landowner and lawyer Karl von Benekendorff, who compiled eight volumes of his insights on estate management and the historical evolution of the system of domains, as well as on the way that nobles and peasants used the law to regulate their relations. ${ }^{33}$ Translated into various European languages, Storch's work was widely used by Jean-Baptiste Say, generations of the German historical school, and lastly the principal Russian economists of the turn of the twentieth century. ${ }^{34}$

According to these German economists in Russia, agricultural reform thus ought to consist of measures that favored investment and involved the large noble landlords but that did not touch the essentials of serfdom or the system of ranks. Arguably, it was precisely the emphasis on agricultural techniques and the organization of communal property that made it possible to relegate the question of labor and serfdom to the background. The works of French and English agronomists were widely disseminated among Russian reforming nobles. Confino illustrates this phenomenon perfectly, in both its momentum and its limitations, showing how noble landowners often undertook "reforms" by resorting to the customary methods of coercion to overcome the peasants' resistance to change. The nobles' written administrative instructions (instruktsii), which sought to regulate affairs on the local level, testify to this attitude. ${ }^{35}$

Even taking into account the role of cameralism and Russian conditions (such as the peculiar status of economists and academics and the persistence of serfdom), such an approach would have been inconceivable without similarly ambivalent attitudes within all tendencies in Enlightenment thought concerning labor, the relationship between law and economics, and the notion of educating peasants and workers.

These factors help explain contemporary observers' and later historians' drastically dissimilar assessments of Russia's economic development during this period. Depending on one's choice of estates and regions, one can highlight either stagnation or agricultural growth; ${ }^{36}$ this scale effect testifies to the diversity of individual situations but also to the complexity of the system. As Confino has shown, the difficulty of transmitting new agricultural techniques was not only connected to the close link between these techniques and the social organization of the village and of Russia in general. Rather the complexity of the laws of the time is also reflected in the fact that the extent of the serfs' duties on the estate, and even the relative degree of their involvement in domestic, agricultural, and (proto-)industrial activities, was negotiable. Although there were no purely formal limitations, the laws governing serfdom 
(especially the legal character attributed to the instruktsii that were issued by the landowners and enforced through the intermediary of village elders and heads of families) ${ }^{37}$ allowed room for negotiation that in turn was responsible for the differences between regions and between estates. ${ }^{38}$ In other words, a mix of incentives and constraints, not simple coercion, prevailed in the economy and society of eighteenth-century Russia. This period thus marks, if not the creation, then the reinforcement, of a direct connection-in ideas as well as economic and political practice-between Russia and various Western countries. Slaves in the colonies, apprentices in France, and serfs in Russia and Prussia all raised the same issue, namely the question of the relation between laborers' legal status and their economic condition. Precisely because this intellectual and economic wave affected both sides is why it would be a mistake to speak of "liberal" attitudes rooted in Western culture that in Russia were changed into merely partial reforms imposed from above. Quite the contrary: uncertainty about the status of labor and whether it made sense to preserve forced labor or the guilds, at least temporarily, was just as apparent in Russia as in France, Great Britain, and Germany; in all four countries, doubts persisted about the economic efficiency and social justice of a free market in both goods and labor.

In this context, some believed that economic conditions could be improved without touching the legal status quo, while others argued that only a radical overhaul of the law (suppressing serfdom, slavery, and the guilds) would ensure both social justice and economic growth. The former had little faith in the laws of the market, while the latter (following Adam Smith) saw Providence itself at work in them. These two positions served as a basis for all the discussions in the nineteenth century about the problems of proletarianization and of liberty versus new serfdom.

\section{The Proletarians Are the Real Serfs: Utopian Socialism, Christian Socialism, and Radical Thought}

In France as in England, in Russia as in Germany, the first half of the nineteenth century was distinguished by interest in a question that, while partly inherited from the preceding period, would intensify throughout the century (especially after 1850): should wage labor and industrialization be judged as progress and freedom from serfdom, or should it be seen as a new slavery? This debate over the rapid growth of wage labor and the condition of the worker was in fact at the heart of a discussion about the values of bourgeois and capitalist society. The critiques of wage labor as a new form of slavery spanned the continent and the political and intellectual landscape. They could be found among both Utopian and 
Christian socialists, French ultra-Catholics, and, finally, in Marx. All spoke of wage labor as a new form of slavery, with minors and children held up most often as evidence. The criticism of a capitalism that lacked morals and restraints served to justify calls for the creation of cooperative and fraternal organizations, a return to Christian morality, or a critique of both capitalism and the regimes that emerged from the French Revolution.

While positions of the economists who connected slavery and wage labor were criticized as unscientific, even Marx ultimately succumbed to this rhetoric. He thus equated modern domestics with the house slaves of ancient times, ${ }^{39}$ described industrial child labor as veritable slavery, and argued that under capitalism, slavery was barely veiled. ${ }^{40}$ As a result, slavery was distinguishable from wage labor only in the way that surplus value was extracted. ${ }^{41}$

Nor, lastly, were the liberals and utilitarians any clearer. Jean-Baptiste Say morally condemned slavery but added that the right of slave ownership imposed restraints on the master as well as the slave, particularly against encroachments by the master and against any injury to the slave's capacity for labor. He also saw slavery as beneficial to the division of labor and to productivity. ${ }^{42}$

Though paradoxical at first glance, we also find this criticism of wage labor-and hence a certain rehabilitation of serfdom or slavery-in authors who, unlike Marx, Say, or Ricardo, put ethical considerations first. Thus, in one of the letters Frédéric Le Play wrote to his sister in 1844 from Nizhnyaya Salda, he marveled at the beauty of nature and the conditions of the serfs: "The peasant serfs in this part of Russia, and particularly on this estate, enjoy a well-being of which French peasants and workers have no idea. Every family possesses for its property a house and a garden as large as the family could desire. In the same enclosure, there is, apart from the house and garden, a courtyard and a building for the animals and provisions." 43

The Russian case is precisely what strengthened Le Play's convictions about industrialization in France and the West: individualism and the accumulation of wealth degraded men, negating their humanity, and formal freedoms did not prevent material servitude. This point is crucial for all Utopian socialist and Christian socialist literature of the first half of the nineteenth century, which argued that formal liberty counts for little if industrialization creates material subjugation. At a certain point, economic laws become more powerful than juridical laws, so the only possible solution is to moralize the economy.

These observations can also be found among French travelers of the time. Thus between 1819 and 1824, Émile Dupré de Saint-Maure discussed serfdom in Russia while really thinking about Napoleon and 
the revolution. He emphasized that "the thought that there are still, in Europe, Christians who are tied to the land is as burdensome to the imagination as it is to the heart." Yet he added that freedom should not be granted too abruptly, or "there will be more opposition from the peasants than among the nobility." He cited the liberation brought by Napoleon and how the peasants themselves had asked to return to their previous condition once the French army had left. In his eyes, these reactions were explained by the advantages of serfdom: "The Russian peasant is less subject to anxieties and fears of impoverishment than those of other countries. The landowner is completely responsible for the existence of those who cultivate the fields. . . Accidents, drought, or winter do not bother the peasant, because the master will take care of [these problems]." Likewise, he claimed that in industry, where "the number of arms often exceeds the need for them . . the worker is never plagued with fatigue, he does his job peacefully, like our day laborers in France, who do things at their own relaxed pace. One never sees, as with us, women working laboriously in the vineyards or handling a spade or children degrading their nascent strength through premature toil." Finally, he thought, one should not believe that large French farms that relied on wage labor were more profitable than Russian estates, as supervisors could not really keep watch over the workers, and once their eyes were turned, the workers would stop working. ${ }^{44}$

Returning to the old Enlightenment arguments of the 1780s, Custine and Jean-Baptiste May argued that while serfdom might be repugnant to the Christian soul, it should not be abolished in one blow, both because the Russians were not yet ready - in Custine's view, "It will take a century and a half to reconcile [their] national customs with European ideas"and because such a step risked leading Russia onto the perverse European path of industrialization. ${ }^{45}$ The critiques of industrialization and of revolution were ultimately the same: "It is to Russia," Custine observed, "that one must go to realize how terrible it is when European ideas are combined with Asia. . . . Is revolution as tyrannical in Paris as despotism is in St. Petersburg?" 46 And it fell to Balzac to conclude that "the Russian peasant is one hundred times happier than the twenty million Frenchmen who make up the [common] people. The Russian peasant is protected [and] would refuse his freedom." ${ }^{47}$

This image apparently contrasts to that of Britain, where pamphleteers, jurists, newspaper editors, and geographers presented their country as an island of liberty in a world full of slaves. There were Polish and Russian peasants who were mere slaves; there were beautiful Caucasian slaves, Christian slaves in the Ottoman Empire, galley slaves in France, and European slaves in North Africa. ${ }^{48}$ In 1772, Arthur Young estimated 
that of 775 million people on the face of the earth, only 33 million possessed freedom. ${ }^{49}$

Still, anti-slavery sentiment in Britain, although undoubtedly with a greater public resonance than in France, ${ }^{50}$ had important limitations expressed not only in political and philosophical thought, but in the attitudes of justices and the law, as well. The following chapters will discuss these matters in detail. Before that, the questions posed by different currents in Western economic thought in the first half of the nineteenth century can be summarized as follows: The issue of the time was whether or not forced labor could be profitable. For those who thought it could be, there was the question of deciding between purely economic criteria and ethical ones. Some held that slavery should be suppressed even if it was more productive, while others raised doubts about this conclusion, as many eighteenth-century philosophes and physiocrats had. The debate about slavery was inseparable from the one about wage labor. It was precisely the reflection on the permissibility of forced labor and slavery that led several economists to question the exploitation of children, women, and wage laborers in general.

All the same, in Russia, during the first half of the nineteenth centuryespecially during the reign of Nicholas I-Russian reformers and intellectuals often shared the tendency of some Western economists to relativize the opposition between free and forced labor. Proletarians became slaves, while serfs enjoyed quite reasonable living and working conditions. From there it was but a step to not seeing any opposition between changes from below (through the education of nobles and peasants) and reforms imposed by force, from above. Both methods could coexist perfectly, just as incentives and constraints could both serve to regulate labor. This is also why there was no pro-serfdom movement in Russia of the same magnitude as the one defending slavery in the United States. Kolchin explains these different attitudes by the fact that in the United States the opposition between master and slave was rooted in race and not legal status (as in Russia), and that American slave owners lived on their estates, whereas Russian nobles were absentees. But that is only part of the argument. In Russia, the debate on serfdom was but one of a number of changes to take place in the country during a period of dramatic social and political upheaval. Like Russia's political and intellectual elites, its nobility were ultimately less afraid of the peasants' emancipation than of their proletarianization; and as the latter issue became the focus of the discussion, the nobles gradually came to accept the abolition of serfdom. At some point, the idea that wage labor was the worst form of slavery was accepted by much of the Russian elite. That is why in the twenty years preceding emancipation, the debate on serfdom intersected with that about the 
commune and then about Russia's "uniqueness" vis-à-vis the West. ${ }^{51}$ It was not so much the abolition of serfdom that was discussed, but the when and how, and consequently the status of the commune and of property. The emphasis on the commune and private property made it possible to relegate to the background the details of what emancipation was supposed to mean and just what kind of labor contract and labor relations would be put in place after the emancipation. ${ }^{52}$

Confirmation of this argument can be found in the way that Russian liberal thinkers envisioned labor in these years. Consider the case of Ivan Vernadskii, Professor of Political Economy and Statistics at the University of Kiev and then at the University of Moscow, and his wife Mariia. ${ }^{53}$ Their starting point was the Adam Smith exalted by nineteenth-century liberal thinkers, namely, the theorist of the division of labor. Mariia Vernadskaia echoed Say's interpretation of Smith: that since the division of labor is the core principle of the economy, it is the basis on which all forms of organization, including slavery and serfdom, should be judged. As we saw earlier, Say concluded that serfdom should be condemned solely for moral reasons, despite sometimes being advantageous by strictly economic calculations. Vernadskaia arrived at the same conclusion and argued that East Indian plantations were an example of efficient division of labor. ${ }^{54}$ From there it was but a step to asking first how to implement emancipation and then how to supervise and control the freed laborers.

\section{Conclusion}

Several general conclusions present themselves. In looking at the nineteenth as in the eighteenth century, it is difficult to speak of a "distortion" of Enlightenment and (later) liberal philosophy by Russian economists and administrators whose thinking supposedly continued to be influenced by the management of forced labor. On the contrary, as the cases of Say or Le Play demonstrate, the same ambivalence about forced labor-measuring it sometimes against moral principles and at others solely by a rational economic calculus-was widespread in Europe. This confirms a much more fundamental dilemma that extended beyond nineteenth-century liberal thought and concerned the freedom of labor and its relationship to morality and ethics, as well as politics. The dilemma involves the status of "free" labor and the role of law in relation to the economy. The economic rationality that issued from the French Revolution and was further developed over the first half of the nineteenth century had trouble reconciling these elements. That is why in the United States, even more than in Russia, it was the moral and 
political arguments-particularly in the context of the shifting political balance in Congress - and not the strictly economic arguments, that enabled the victory of abolitionism. ${ }^{55}$

The relationship between labor and authority is central in this context. In Russia, as in Europe and the United States, the entire debate centered on the question of knowing how to increase productivity, whether through tighter controls or enhanced worker incentives. These were seen as the two available options, but it was not possible to entirely link either one to forced labor or wage labor. Although it might seem that serfdom involved constraint and wage labor involved freedom, the debates show precisely the opposite, for the partisans of a reformed (but not abolished) serfdom advocated giving the serfs more responsibility; they maintained that free wage labor entailed far greater supervising costs. Conversely, the most radical reformers considered coercion and serfdom to be less profitable than free labor, but paradoxically they did not hesitate to adopt coercive methods in order to impose reforms. This also tells us that the boundary between free and forced labor is not defined in some abstract and timeless way; rather, it is historically specific, and through discussions and practices it is continually brought back into play.

Of course, within this shared problematic and chronology we also find specificities. Thus the French images of Russia and serfdom were rooted in the difficult evolution from the guilds to the labor market and in the abolition of slavery. Later, after the revolution, the role of labor in capitalist society and of the peasants in Russia became connected to the memory of the revolution and to the character of the new political system, but also to the discipline of the markets. In Russia, these same debates about labor were rooted both in the relations between the nobles and the tsar and in the social position of knowledge and intellectuals. Both issues were at stake as the various parties discussed the status of serfs and workers. The solution was found in a particular plan that aimed to suppress serfdom without letting the peasants fall to the status of proletarians. Although this plan has been held up repeatedly as a case in point of Russian uniqueness, in reality it responded perfectly to utopias that were shared not just in Russia but also, and indeed especially, in the West, at that time. The dream of the Enlightenment in the mid-eighteenth century, but also of Le Play and many others, was precisely to link the reform of the Old Regime with measures to avoid the pauperization, proletarianization, or exploitation - the terms varied from one period to the next - of the mass of urbanized former peasants. Another dimension of this same utopia involved laborers who were inventive and free yet disciplined and bound by clear relations of subordination. That knot remains to be untied even now. But this attitude in Western thought, contrary to the received 


\section{wisdom, drew its inspiration less from Smith than from Bentham. It is now time to turn to the history of the Panopticon.}

\section{Notes}

This chapter is a revised version of my article "Free Labor-Forced Labor: An Uncertain Boundary? The Circulation of Economic Ideas between Russia and Europe from the Eighteenth to the Mid-nineteenth Century," which appeared in Kritika: Explorations in Russian and Eurasian History 9, 1 (2008), 1-27. I would like to express my gratitude to Kritika and the Muse project for granting the permission to reproduce it.

1. Albert Lortholary, Le mirage russe en France an XVIII siècle (Paris: Éditions contemporaines, 1948); Jan Struys, Les voyages en Moscovie, en Tatarie, Perse, aux Indes et en plusieur pays étrangers (Amsterdam: Van Meers, 1681); Pierre de la Martinière, Voyages des païs septentrionaux (Paris: L. Vendame, 1671); John Perry, État présent de la grande Russie (The Hague: H. Dusanzet, 1717); John Cook, Voyages and Travels Through the Russian Empire, Tartary, and Part of the Kingdom of Persia (Edinburgh, no publisher1770) .

2. Charles Secondat, baron de Montesquieu, Esprit des lois (Paris: Garnier, 1967, orig. 1748), chapitre XV ; Michèle Duchet, Anthropologie et histoire au siècle des lumières (Paris: Albin Michel, 1971).

3. Victor Riqueti Mirabeau, Lami des hommes, ou Traité de la population (Avignon: no publ., 1758), 177.

4. Edward D. Seeber, Anti-slavery Opinion in France during the Second Half of the Eighteenth Century (Baltimore: Johns Hopkins Studies, 1937); Henri Sée, "Les économistes et la question coloniale au XVIII' siècle," Revue d'histoire des colonies 1 (1929): 381-92; André Labrouquère, Les idées coloniales des physiocrates (Paris: PUF, 1927).

5. On these aspects, see, among others, Steven L. Kaplan, La fin des corporations (Paris: Fayard, 2001); Michael Sonenscher, Work and Wages (Cambridge: Cambridge University Press, 1989); Philippe Minard, La fortune du colbertisme. Etat et industrie dans la France des Lumières (Paris: Fayard, 1998); Gilbert Faccarello and Philippe Steiner, La pensée économique pendant la révolution française (Grenoble: Presses universitaires de Grenoble, 1990).

6. Abbé Baudeau, “De l'éducation nationale," Éphémérides du citoyen 2, 11 (1767): 165-85.

7. Baudeau published four articles about Russia in Éphémérides du citoyen 6, 5 (1766), 65-80; 6, 6 (1766), 81-96; 6, 7 (1766), 97-112; 6, 8 (1766),133-28.

8. Turgot's library contained works on the north and the east, as well as on trips around the world, but not on voyages to America or Africa. See Duchet, Anthropologie et histoire, 73.

9. A. R. J. Turgot, Oeuvres et documents le concernant, 5 vols., ed. Gustave Schelle (Paris: Félix Alcan, 1913-23), 2:375. See also Turgot, "Plan de deux discours sur l'histoire universelle," in Turgot, Oeuvres et documents le concernant, 1:275-324.

10. François-Marie Voltaire, Histoire de l'Empire de Russie sous Pierre le Grand (Paris, 1763), reissued in Voltaire, Oeuvres historiques, ed. René Pomeau (Paris: Pléiade, 1957).

11. Voltaire, "Letters to Catherine II of 1762, 1765, and 1766," in François-Marie Voltaire, Correspondance, 107 vols., ed. Théodore Bersterman (Geneva: Institut et Musée Voltaire, 1953-65).

12. Denis Diderot, "Propriété des terres et agriculture: 4 questions," and "Questions à Catherine II sur la situation économique de l'Empire de Russie," in Diderot et Catherine II, ed. Maurice Tourneux (Paris: Calmann Lévy, 1899), reproduced in Denis Diderot, Mémoires pour Catherine II (Paris: Garnier, 1966). The quotation is from the 1899 edition, 813-17.

13. Denis Diderot, "Observations sur le Nakaz de Catherine II," in Denis Diderot Oeuvres politiques (Paris: Garnier, 1963), 365. 
14. See Gilbert Faccarello, "Galiani, Necker, and Turgot: A Debate on Economic Reform and Policy in Eighteenth-century France," in Studies in the History of French Political Economy from Bodin to Walras, ed. G. Faccarello (New York and London: Routledge, 1998), 120-95, particularly 179 fn. 23.

15. Duchet, Anthropologie et histoire, $134 \mathrm{f}$.

16. Bennot-Etienne, abbé de Condillac, Oeuvres de Condillac, 23 vols. (Paris: C. Houel an VI [1798]), 20:63-64.

17. Yves Benot, "Condorcet journaliste et le combat anti-esclavagiste," in Condorcet mathématicien, économiste, philosophe et homme politique, ed. Pierre Crépel and Christian Gilain (Paris: Minerve, 1989), 376-84; Joseph Jurt, "Condorcet: l'idée de progress et l'opposition à l'esclavage," in Benot, Condorcet mathématicien," 385-95.

18. Guillaume-Thomas Raynal, Histoire philosophique et politique des établissemens et du commerce des Européens dans les deux Indes, 10 vols. (Neuchatel and Geneva: Librairies associées, 1780).

19. Jean-Claude Perrot, Histoire intellectuelle de l'économie politique (Paris: EHESS, 1992).

20. On the influence of Raynal on Radishchev, see Vladimir I. Moriakov, Iz istorii evoliutsii obshchestvenno-politicheskikh vagliadov prospetitelei kontsa XVIII veka: Reinal' $i$ Radishchev [On the history of the evolution of the sociopolitical orientations of institutors during the eighteenth century: Raynal and Radishchev] (Moscow: Izdatel'stvo Moskovskogo Universiteta, 1981); Allison Blakely, "American Influences on Russian Reformists in the Era of the French Revolution," Russian Review 52, 4 (1993): 451-71. On Nikolai Novikov, see editor's note of 1784, reproduced in Nikolai.I. Novikov, Izbrannye sochineniia [Selected works] (Moscow: Gosudarstvennoe izdatel'stvo khudozhestvennoi literatury, 1951), 562.

21. On the impact of the American case on Russia in this era, see Blakely, "American Influences on Russian Reformists"; Max Laserson, The American Impact on Russia: Diplomatic and Ideological, 1784-1914 (New York: Macmillan, 1950); and Richard Hellie, Slavery in Russia, 1450-1723 (Chicago: University of Chicago Press, 1982). This link between events in the United States and radical reform survived to the start of the nineteenth century, when the slave revolt in Santo Domingo of the 1970s excited Karamzin. See Nikolai Karamzin, "Khronika," Vestnik Evropy (1802): 83-84; and Nikolai Karamzin, Karamzin's Memoir on Ancient and Modern Russia, ed. Richard Pipes (Cambridge, MA: Harvard University Press, 1959), 45.

22. See "Razmotrenie o voprose-mogut li dvoriane zapisyvat'sia v kuptsy" [Notes on the question: can nobles register as merchants?], in Mikhail M. Shcherbatov, Neizdannye sochineniia [Unpublished works] (Moscow: Sotsekgiz, 1935), 139-58; Marc Raeff, "State and Nobility in the Ideology of M. M. Shcherbatov," American Slavic and East European Review 19, 3 (1960): 363-79; Elise K. Wirtschafter, Structures of Society: Imperial Russia's People of Various Ranks (DeKalb: Northern Illinois University Press, 1994); idem, Social Identity in Imperial Russia (DeKalb: Northern Illinois University Press, 1997).

23. Vasilii N. Tatishchev, Istoriia rossiiskaia v samykh drevneishikh vremen [History of Russia since the most ancient times] (Moscow: Imperatorskii Moskovskii Universitet, 1768) and Izbrannye trudy po geografii Rossii [Selected works on the geography of Russia] (Moscow, 1779; reissued Moscow: Gosudarstvennoe izdatel'stvo geograficheskoi literatury, 1950).

24. Albion Small, The Cameralists: Pioneers of German Social Policy (New York: Burt Franklin, 1909); Hans Rosenberg, Bureaucracy, Aristocracy, and Autocracy: The Prussian Experience, 1660-1815 (Cambridge, MA: Harvard University Press, 1966); Carl William Hasek, The Introduction of Adam Smith's Doctrine Into Germany (New York: Columbia University Press, 1925); Keith Tribe, Governing Economy: The Reformation of German Economic Discourse, 1760-1840 (Cambridge: Cambridge University Press, 1988); and Marc Raeff, The Well-ordered Police State: Social and Institutional Change Through Law in the Germanies and Russia, 1600-1800 (New Haven: Yale University Press, 1983). 
25. "Obshchestvennaia i chastnaia zhizn' Avgusta Liudvig Schletser im samim opisannaia," in Sbornik russkogo iazyka i slovesnosti imperatorskoi akademii nauk (Collection of Russian language of the Imperial academy of sciences) 13 (1875).

26. On political arithmetic and its reception, see Mary Poovey, A History of Modern Fact (Chicago: University of Chicago Press, 1998); Joyce Oldham Appeleby, Economic Thought and Ideology in Seventeenth-century England (Princeton: Princeton University Press, 1978); Alessandro Roncaglia, Petty: The Origins of Political Economy (Armonk, NY: M.E. Sharpe, 1985); and Perrot, Histoire intellectuelle.

27. Among the authors who encouraged this interpretation are A. Krafft, writing in Nova Acta Academiae Scientiarum Imperialis Petropolitanae 4 (1786) and 8 (1790);; "O sovremennom polozhenii sel'skogo khoziaistva v Rossii, predstavlen 13 maia 1807" [On the present situation of Russian agriculture, report of May 13, 1807], in Memuary Peterburgskoi Akademii nauk 1 (1909): 662-730; Benedikt Franz Johann Hermann, Statistische Schilderung von Russland ( Leipzig: in Commission bey Friedrich Gotthold Jacobäer, 1790); Heinrich Storch, Statistische Uebersicht des Statthalterschaften des Russischen Reichs (Riga: bei Johann Friedrich Hartknoch, 1795); August Ludwig Schlözer and J. M. Schroeck, Histoire universelle, destinée à l'instruction de la jeunesse (The Hague: I. van Cleef, 1800); Heinrich Storch, Tableau historique et statistique de l'empire de Russie à la fin du 18ème siècle (Paris: Ch. Pougens Imprimeur, 1801).

28. Monthly Magazine (May 1800): 348.

29. Christian Schlözer, Histoire universelle (The Hague: chez I. van Cleef, 1800) 2:261-64.

30. Confino has persuasively demonstrated the connection between the three-year rotation of crops and social organization. See Michael Confino, Systèmes agraires et progrès agricole. L'assolement triennial en Russie au XVIIIe-XIXe siècles (The Hague: Mouton, 1969).

31. Heinrich Storch, Cours d'économie politique ou exposition des principes qui déterminent la prospérité des nations, 5 vols. (Saint Petersburg: A. Pliushar, 1815), booklet 5: 255, 258, 261, 279, 291-2. On Storch, see Paul Romeo, "Heinrich Storch, Adam Smith, and the Question of Russian Economic Development," M.A. thesis, University of North Carolina, 1996; Roderick E. McGrew, "Dilemmas of Development: Baron Heinrich Storch, 1766-1835, on the Growth of Imperial Russia,"Jahrbücher für Geschichte Osteuropas 24, 1 (1976): 31-71; and Iuri Iu. Bliumin, Ocherki ekonomicheskoi mysli pervoi poloviny XIX veka [Studies of economic thought during the first half of the nineteenth century] (Moscow and Leningrad: Izdatelstvo Akademii nauk, 1940), 173-95.

32. Edgar Melton, "Population Structure, the Market Economy, and the Transformation of Gutscherrschaft in East Central Europe, 1650-1800: The Case of Brandenburg and Bohemia," German History 16, 3 (1998): 297-324; William Hagen, "Village Life in East-Elbian Germany and Poland, 1400-1800," in The Peasantries of Europe from the Fourteenth to the Eighteenth Centuries, ed. Tom Scott (London: Routledge, 1998), 145-90.

33. Karl von Benekendorff, Oeconomia forensic oder kurzer Inbegriff derjenigen landwirtschaftlichen Wabreheiten, welchen allen, sowobl hohen als nedrigen Gerichts-Personen zu wissen nothig, 8 vols. (Berlin: Pauli, 1784). Among the few modern scholars to consult this work is Melton. See his "Population Structure."

34. Esther Kingston-Mann, In Search of the True West (Princeton: Princeton University Press, 1999); McGrew, "Dilemmas of Development"; Alla Sheptun, "The German Historical School and Russian Economic Thought," Journal of Economic Studies 32, 4 (2005): 34974; and Jürgen G. Backhaus, "Heinrich von Storch's Concept of the Use of Mathematics in Political Economy," Journal of Economic Studies 27, 4-5 (2000): 377-81.

35. Emilia I. Indova, "Instruktsiia kniazia M. Shcherbatova prikazchikam ego Iaroslavskikh votchin (1758 g. s dobavleniiami k nei po 1762 g.)," [Instructions of the prince Shcherbatov adopted in his estate of Iaroslav, 1758-1762], in Materialy po istorii sel'skogo khoziaistva i krest'ianstva SSSR. Sbornik 6 (Moscow: AN SSSR, 1965), 460; and John Bushnell, "Did 
Serf Owners Control Serf Marriage? Orlov Serfs and Their Neighbors, 1773-1861," Slavic Review 52, 3 (1993): 419-45.

36. Konstantin Arsen'ev, Statisticheskie ocherki Rossii [Statistical studies of Russia] (Saint Petersburg: Tipografiia Imperatorskoi Akademii Nauk, 1848).

37. A sample of these instruktsii is available at the British Library, additional manuscript $47421,47428,47430$, and 47432 (notably of the Lieven property). On instruktsii, see Edgar Melton, "Enlightened Seigniorialism and Its Dilemma in Serf Russia, 1750-1830, Journal of Modern History 62, 4 (1990): 675-708; Bushnell, "Did Serf Owners Control Serf Marriage?"; and Indova, "Instruktsiia kniazia M. Shcherbatova." On the role of heads of villages and families, see Lidia S. Prokof'eva, Krest'ianskaia obshchina v Rossii vo vtoroi polovine XVIII-pervoi polovine XIXe veka [The peasant commune in Russia during the second half of the eighteenth century to the first half of the nineteenth century] (Leningrad: Nauka,1981); and Vladimir A. Fedorov, Pomeshchich'i i krest'iane tsentral'no-promyshlennogo raiona Rossii kontsa XVIII-pervoi poloviny XIXe $v$ [The peasant commune in Russia during the second half of the eighteenth century to the first half of the nineteenth century] (Moscow: Izdatel'stvo Moskovskogo universiteta, 1974).

38. On these aspects, see Steven Hoch, Serfdom and Social Control in Russia: Petrovskoe, a Village in Tambov. (Chicago: University of Chicago Press, 1986); Wirtschafter, Structures of Society; and Raeff, The Well-ordered Police State.

39. Karl Marx, Il capitale, 3 vols. (Rome: Einaudi, 1972), 1:491-92.

40. Ibid., 1:822.

41. Ibid., 1:250.

42. Jean-Baptiste Say, Cours d'économie politique (Brussels: Meline, Cans et Compagnie, 1843): 522.

43. Frédéric Le Play, Voyages en Europe, 1829-1854 (Paris: Plon, 1899), 201-2.

44. Emile Dupré de Saint-Maure, L’hermite en Russie ou observations sur les moeurs et les usages russes au commencement du XIX siècle, 3 vols. (Paris: Pillet ainé, 1829), 2:163.

45. Jean-Baptiste May, Saint-Pétersbourg et la Russie en 1829, 2 vols. (Paris: Levasseur, 1830), v. 1, ch. 3; and Astolphe de Custine, La Russie en 1839, 4 vols. (Paris: Amyot, 1843), v. 1, letter 10; v. 2, letters $13-14$; v. 4, letter 22.

46. Astolphe de Custine, La Russie en 1839, v. 2, letter 13.

47. Honoré de Balzac, "Lettre sur Kiew, 1847" in Oeuvres diverses (Paris: Louis Conard, 1940): 653-81.

48. Seymour Drescher, Capitalism and Antislavery: British Mobilization in Comparative Perspective (New York: Oxford University Press, 1987), 17.

49. Arthur Young, Political Essays Concerning the Present State of the British Empire (London: Strahan and Cadell, 1772), 20-21.

50. Drescher, Capitalism and Antislavery.

51. Andrzej Walicki is one of countless authors who have analyzed the debate between the Slavophiles and Westernizers during this era. See A. Walicki, The Slavophile Controversy: History of a Conservative Utopia in Nineteenth-century Russia (New York: Oxford University Press, 1975). For an examination of the economic debates on this subject, see Kingston-Mann, In Search of the True West, and my L'économie en revolution. Le cas russe, 1870-1930 (Paris: A. Michel, 1998).

52. Vissarion G. Belinskii, Polnoe sobranie sochinenii [Complete works], 13 vols. (Moscow: AN SSSR, 1953-59), in particular, vol. 12:444-68; Ivan A. Aksakov, Sochinenii (Works), 7 vols. (Moscow: Tip. M.G. Volchaninova, 1886-87), v. 2; Alexis S. Khomiakov, Polnoe sobranie sochinenii, 8 vols. (Moscow, Universitetskaia tipografiia, 1900), v. 3; Pavel A. Zaionchkovskii, The Abolition of Serfdom in Russia (Gulf Breeze: Academic International Press, 1978); Terence Emmons, The Russian Landed Gentry and the Peasant Emancipation of 1861 (Berkeley: University of California Press, 1968); Lidia G. Zakharova and John Bushnell, eds., The Great Reforms in Russia (Bloomington: Indiana University Press, 1994); and 
Boris N. Chicherin, Sobstvennost' i gosudarstvo [Property and the state], 2 vols. (Moscow, 1882-83; new edition, Saint Petersburg: Izdatel'stvo Russkoi Khristianskoi gumanitarnoi akademii, 2005).

53. See the following works by Vladimir Vernadskii: Politicheskoe ravnovesie $i$ Angliia (Moscow: Univer. tipografiia, 1854); Ocherk istorii politicheskoi ekonomii (Saint Petersburg: Red. Ekon. Uzak.,1858); and Prospekt politicheskoi ekonomii (Saint Petersburg: Red. Ekon. Uzaz., 1858). On Vernadskii, see V. N. Rozental', “Obshchestvenno-politicheskaia programma russkogo liberalizma v seredine 50-kh godov XIXe veka," Istoricheskie zapiski 70 (1961): 197-222.

54. Mariia Vernadskaia, Sobranie sochinenii [Selected works] (Saint Petersburg: Red. Ekon. Uzak., 1862),76.

55. Kolchin, Unfree Labor. 


\section{Poor Laws, Management, and LABOr Control in Russia and Britain, OR THE History OF THE BENTHAM BRothers IN Russia}

Between 1780 and 1787, the brothers Samuel and Jeremy Bentham were managers of a large Russian estate owned by Prince Grigorii Potemkin, one of the closest advisors of Catherine II. In doing so they faced two related-but distinct-problems: Russian peasants were unskilled, and British skilled workers and supervisors, who had been brought in to work on the estate, were hard to control. Ultimately, the problem of supervising the English workers (and not the Russian serfs) is what led the Bentham brothers to reflect on the relationship between free and forced labor, and then between labor and society. Before and after Foucault, ${ }^{1}$ the Benthams' Panopticon has been seen as a response to social deviance and as a concept related to prisons and the emergence of a global surveillance system in modern societies. I want to challenge this view by arguing that the Panopticon project actually was a system for controlling wage labor, which drew inspiration from a particular image of Russian serfdom and from the Bentham brothers' experiences in that country. I shall also examine the impact that debates on the Poor Laws in Britain had on Bentham's conceptions of labor and, thus, their influence on his Russian experiences. The section that follows discusses the fate of the Panopticon and nineteenth-century conceptions, politics, and practices of labor, in both Britain and Russia. A new understanding of their convergence and differences is the ultimate goal of my analysis. ${ }^{2}$ 


\section{A Global History of Labor Control: The Case of the Bentham Brothers in Russia}

Samuel Bentham, Jeremy's brother, arrived in Russia in 1780, as a naval engineer. At first he first worked for an English manufactory in St. Petersburg and then toured the Ural Mountains in 1781-82, before entering the service of Prince Potemkin, in 1784. The prince was at this time Catherine's lover and close advisor, and he owned country estates and numerous factories. He was also directly involved in the ongoing Russian expansion, east to Poland and south to Crimea. The government was then devoting much attention to the development of a short stretch of Black Sea coast that it had secured from Turkey in 1774. These ambitions generated tensions and conflicts with the Ottoman Empire, and an alliance with Britain was part of the Russian strategy. It was thus not by chance that Potemkin asked Samuel Bentham to manage one of his estates, located in the Krichev district of Belorussia.

Russia had seized Krichev from Poland in the first partition, in 1772; it had belonged to Polish magnates who refused to give fealty to Catherine II, who granted the estate to Potemkin. The estate was a large one and included five towns. Krichev's inhabitants were Russians, Germans, Don Cossacks, and Polish Jews. Farming was the main pursuit there, but the district also had rich resources of timber for shipbuilding. The people were known for their skills in carpentry, and local landowners, including Potemkin, began to bring in other skilled craftsmen, causing the male population to grow from fourteen to twenty-one thousand, between 1776 and $1785 .{ }^{3}$ When Samuel Bentham arrived at Krichev he found a brandy distillery, a factory, a tannery, copper works, a textile mill with 172 looms for making sailcloth, and a ropewalk ${ }^{4}$ with 20 wheels, supplying Kherson's shipyards. ${ }^{5}$ In fact, the estate was the principal supplier to naval stores down to the Black Sea. Bentham's main task was to build ships for Potemkin, however he found himself faced with a twofold problem involving labor that was both unskilled and undisciplined. The first problem was that the estate's serfs lacked the skills needed for building ships. To address this problem, he suggested that both machines and skilled workers be brought in from Britain. Potemkin's Anglophilia encouraged this approach-he did not care about details, but he wanted Englishmen to drive Krichev's looms and run his botanical gardens, windmills, and shipyards, from the Crimea to Krichev. When twenty skilled workers arrived on the estate in 1785, disciplinary problems quickly surfaced. The English workers showed little respect for instructions or work schedules, and while their foremen complained about the lack of discipline, 
they too disobeyed Bentham's instructions. ${ }^{6}$ John Debraw, in charge of their supervision, described them as "a Newcastle mob-hirelings from the rabble town; a good-for-nothing crowd demanding high pay for no return." Jeremy Bentham noted "a lack of discipline and order among the workmen," 8 and one foreman even threatened to lodge a complaint with Potemkin and Catherine. It was in this context that Jeremy, who had joined his brother a few months earlier, wrote numerous letters that took up these problems and called for an improvement in the system of labor surveillance, particularly regarding the work of the foremen. ${ }^{9}$ The letters addressed the well-known problem of how to supervise the supervisors: "With regard to instruction, in cases where it cannot be given without the instructor's being close to the work, or without setting his hand to it by the way of example before the learner's face, the instructor must indeed ... shift his station as often as there is occasion to visit different workmen." ${ }^{10}$ Jeremy was impressed by the virtues of the Panopticon principle elaborated by his brother: "Relative to a house of correction ... it occurred to me that a plan of a building, lately contrived by my brother, for purposes in some respects similar, and which, under the name of the Inspection house, or the Elaboratory, he is about erecting here, in Krichev, might afford some hints for the above establishment. . . . To say all in one word, it will be found applicable, I think, without exception, to all establishments whatsoever, in which, within a space not too large to be covered or commanded by buildings, a number of persons are meant to be kept under inspection." "Jeremy completed this project by creating a drawing of the architecture of the Panopticon. These letters would become famous, because they contained the Panopticon project or model prison; they were subsequently assembled into the Panopticon letters, published first in $1791 . .^{12}$

The prison project, then, was first of all a project for labor surveillance, and the unskilled serfs were less of a concern than the skilled foremen. The project was not a reaction to the indiscipline of Russian serfs, but on the contrary, it was a response to the behavior of English foremen and skilled workers. Russia thus inspired Bentham with a model of labor organization and surveillance that could be applied in Europe, and in England in particular, as Jeremy Bentham suggested in his correspondence. ${ }^{13}$ Most of the countless interpretations of the Panopticon, including Foucault's, go wrong precisely because they overlook this context and hence the link between prison and labor, on the one hand, and free and forced labor, on the other. At the same time, it should be stressed that the Panopticon was not the reaction of an English liberal confronted with an absolutist system and forced labor. For Bentham, after all, the point was precisely to improve the surveillance and labor efficiency of English wage workers. 
It is therefore incorrect to assert that Bentham's attitudes expressed the exclusive influence of absolutist Russia on an English liberal; rather, these concerns reflected the evolution of legal and economic organization of the Russian estates, as well as those that arose during this period in Great Britain, with regard to labor discipline in the newly emerging industrial world. To prove these assertions, I first detail the way Russian estates were managed at the turn of the eighteenth to the nineteenth century, and I then discuss the status of labor in Britain.

\section{Estate Organization in Russia: Instruktsiia, or How to Supervise the Supervisor}

Tsarist state rules did not regulate estate organization or the work of the peasants. The first law to do so dates from 1797 and limited forced labor on private estates to three days a week. Further state rules on this subject did not appear until the years preceding emancipation. Yet this situation did not mean that estate organizations were placed entirely in the hands of noble landowners, free to engage in abusive practices toward peasants, as several historians have claimed. ${ }^{14}$ Although state law did not control relationships within estates directly, it nevertheless laid down a framework of operating rules. Seigniorial justice has often been taken to be a synonym for feudalism, the old order, and serfdom, in medieval and modern Europe and in modern Russia. More recent approaches have substantially modified this picture regarding modern Europe, as well as modern Prussia, Lithuania, and, last but not least, Russia. ${ }^{15}$ I shall follow this line of thought and demonstrate that instruktsiia and legal documents issued by the landlords cannot necessarily be taken as synonymous with peasants' submission and enserfment or their coerced exploitation. In Russia at the end of the seventeenth century, several estates published instructions or edicts (nakazy, instruktsiia) that (along with a collection of national laws) sought to provide a list of the rules for a given estate. The state gave these regulations the force of law. This formal framework is important, because it testifies to the tsarist state's determination not to abdicate its authority inside the estates but rather to decentralize the production and application of the pertinent rules. These rules therefore supplemented rules applicable throughout the country, which defined who was entitled to own and transfer inhabited estates. State order determined the institutional definition of the noble landowner and granted him the right to promulgate the rules of his estate. In other words, the tsar could withdraw a lord's authority at any moment if he abused his power or if his entitlement to own land did not comply with the rules. 
Until about 1750 , these instruktsiia concerned taxation and estate administration above all, and the organization of actual farmwork remained in the background. ${ }^{16}$ This was because at that time most noble landowners were required to justify their right to ownership, cope with the introduction of capitation, and integrate their various activities, whether related to farming or not, within the estate.

Significant changes took place in the 1760s, when the instruktsiia began to focus more on work organization and the role of bailiffs. ${ }^{17}$ This was the time when both the Free Imperial Economic Society and Western economists (Bentham above all) focused on the question of supervision in organizations. In the estates, this change was accompanied by a corresponding modification in the form and dissemination of the documents employed. The number of instruktsiia increased, although they still affected only a minority of estates. Victor Aleksandrov, one of the leading Soviet specialists in these documents, found them mostly in estates belonging to the wealthiest nobles, those with more than five hundred male peasants under them. Although this group made up only 5 percent of the noble population, 55 percent of private peasants were on these estates. Potemkin, with his twenty thousand male peasants, was at the very top of this list. ${ }^{18}$

The dissemination of instruktsiia during the second half of the eighteenth century has been commonly and relatively consistently interpreted as a confirmation of the "golden age of nobility" in Russia. It has been asserted that at the time of Catherine II, nobles benefited from considerable privileges, including the right to freely exploit peasants based on specific rules validated by the state. ${ }^{19}$ But was this really the case?

No doubt Catherine herself encouraged the publication of these instructions, both at the time of her reforms in 1767 and in the Charter to the Nobility, in 1785, as it was in keeping with the logic of a "well-ordered state" typical of this autocracy and the Prussian regime of the same period. ${ }^{20}$ However, debates within the commissions set up by Catherine, as well as the official laws adopted at the time, emphasized the importance of having not only an administrative and police order, but an economic order as well. The nobles were supposed to run their estates in a more rational way, both in the sense of using more advanced farming techniques and of laying down appropriate operating rules to govern the peasants as well as the bailiffs. At the same time, for enlightened seigniors, moral and economic issues were not separate categories; the problems of poverty and moral order were closely connected. ${ }^{21}$ This met the state's interest in reducing social tensions (particularly after the Pugachev revolts in $1774-75$ ) and in preserving its pool of soldiers. ${ }^{22}$ 
For similar reasons, the instruktsiia granted considerable weight to village communities and elders. ${ }^{23}$ State rules acknowledged and legitimized the instruktsiia and acknowledged the existence of peasant customary law and village communities. This hierarchy of legal rules aimed to promote mutual control by the actors and a certain amount of flexibility within the system. Although the traditional views of historians suggests otherwise, under serfdom both manors and commune were strong. ${ }^{24}$ Of course, this legal and social order did not exclude conflicts or even unrest. Petitions were sent to landowners ${ }^{25}$ and uprisings occurred, and in some cases there were acts of violence against the bailiff or the landowner. ${ }^{26}$ These actions were not always a reaction to the services demanded by the landowners but, on the contrary, often came in response to technical or organizational innovations. ${ }^{27}$

Most important to us, however, is the way conflicts were resolved; despite political importance of the instruktsiia, historians have given insufficient attention to the uses peasants made of village, estate, and state institutions, and instead overstress the role of conflict. Rather than opposed to one another, these institutions were in fact complementary. The instruktsiia designated legal proceedings to be undertaken by the appropriate judicial authorities (peasant court, estate litigation offices). Thus Roman Voronotsov, the owner of one of the largest estates and a member of the IVEO (the Free Imperial Economic Society), encouraged the introduction of peasant courts to settle disputes between peasants themselves and between peasants and bailiffs. ${ }^{28}$ On large estates such as Sheremetev, conflicts were settled through a central office of all the estates, in accordance with clear-cut rules. ${ }^{29}$ Potemkin used the same system in Krichev.

In other words, the tsarist elites' demand for institutional order coincided more with the strictly economic interests of the noble landowners and the need for economic and social stability within the peasant commune. Landowners were less interested in using these instructions to control the peasants than in using them to control and regulate bailiff activity. ${ }^{30}$ The bailiffs were either nobles themselves (in which case they were called upravitely) or free or unfree peasants (called prikashchiki), and they were concerned with the organization of production, taxation, and the collection of any kind of economic and fiscal information. A complex and hierarchical system of surveillance was in place: Bailiffs deployed agents among the peasants to watch them, and while bailiffs supervised such peasant agents, they were themselves viewed with great suspicion by landlords, who feared both fraud and overexploitation of peasants. To overcome this problem, landlords developed a complex system of 
remuneration, bonuses, and fees for the bailiffs. Remuneration was usually paid in kind, as a fixed proportion of the harvest. Bonuses were of little importance, for innovations were rare. As a consequence, fees played a great role. Bailiffs were held responsible for harvest or quitrent failure, and this pushed them to transfer these losses on to the peasants and thus "squeeze" them further.

Indeed, in the 1760s and 1770s, in the eyes of noble landowners, tsarist leaders, and agronomists, bailiffs were usually corrupt individuals who appropriated a good portion of the lord's revenues for themselves and exploited the peasants without encouraging them. All of this resulted in losses for the lord, because it led to a lack of incentive and motivation on the part of the peasants and could even spark riots. The aim of the instruktsiia during the second half of the eighteenth century, therefore, was quite the opposite of the one put forward by most historians - they were not primarily intended to further squeeze peasants, but to limit abuses by the bailiffs.

These dynamics were pushed forward by the Pugachev unrest and the influence of the Enlightenment and rational estate management. ${ }^{31}$ As agronomists, economists, and philosophers suggested, constraints alone were not enough to ensure efficient use of resources-and particularly labor. Enlightened landowners were especially sensitive to this argument, and, as a supporter of "rational" management and as Catherine's advisor, Potemkin warmly supported it. ${ }^{32}$

Such was the situation when Samuel Bentham arrived in Russia. Bailiffs' activities, on the one hand, and the estate's multiple forms of activity (farming, manufacturing, proto-industry), on the other, were at the core of the ideas and practices on the estate level and within the cultural and political elites. Bentham suggested improving the system for controlling the bailiffs; he also suggested integrating and coordinating skilled and unskilled workers and peasants. At first glance, this solution considered people exclusively in their professional and functionalist aspects (as overseers and skilled or unskilled workers) and ignored the fact that Russian serfs were quite distinct from British free workers. We need to assess this consideration, not only because (as we will see in next chapters) the legal status of Russian peasants was more complex than has usually been stated, but also because British workers had a particular legal status too, and Bentham was fully aware of this.

\section{Controlling Labor: Paupers and Servants in Britain}

According to Bentham, the difference between a servant and a slave is that for the latter, the power of the master is unlimited and the slave 
has no rights. As Jeremy Bentham wrote: "Slavery is susceptible of many modifications and alleviations. . . . There was a great difference between the condition of a slave at Athens and Lacedemon; there is still more between that of a Russian serf and a Negro in the southern states of America. But whatever may be the limits as to the modes of exercising authority, if the obligation of service be unlimited in point of duration, I always call it slavery." ${ }^{33}$ According to Bentham, it was not the condition but rather the duration of the obligation that constituted the real difference between free and unfree labor. The living conditions of a free worker were not necessarily better than those of a slave or serf.

We have to avoid the temptation to translate this qualification into today's categories. At the turn of the century, in Britain as in France and the United States, Adam Smith's argument that free labor was more productive than unfree labor was not fully accepted, even among liberal milieus. Quite the contrary: if, according to the utilitarian principles, one could show that the enslavement of a minority group increased the sum of total happiness, then a rationale for slavery was acceptable. ${ }^{34}$ As we have seen, this argument was advanced among British as well French utilitarians, Jean-Baptiste Say being one of the most important examples. ${ }^{35}$

Such an attitude was all the more widespread because at that time, the notion of "free" labor was not the one we are accustomed to now. As I discuss in detail in chapter 6 , in Britain, until the mid-nineteenth century, most free labor was actually unfree. Servants, apprentices, laborers, and artificers could be imprisoned until they were willing to return to their employers to complete the service they had agreed upon. Wage earners were considered domestics and were above all supposed to provide a service. ${ }^{36}$ The labor of servants was usually conceived as a master's property, and property consisted in the service rather than in the body or person of the captive.

The Benthams fully adhered to this view. According to Jeremy, only by offering a service could a man find "happiness or security." ${ }^{37}$ However, "The master alone is considered as possessing a property, of which the servant, in virtue of the service he is bound to render, is the object; but the servant, not less than the master, is spoken of possessing or being invested with a condition." These relationships of dependence applied also to the superintendent, who was subordinate to the master but was controller of the servant.$^{38}$ That is to say, master and servant did not enter a contract between formally equal persons, but instead each carried a different legal status. Legally speaking, servants were considered much the same as children and married women: they were under the full authority of their master. Because of this, "The most flagrant species of breach of duty, and that which includes indeed every other, is that which 
consists in the servant's withdrawing himself from the place in which the duty should be performed." 39

The legal status of labor provided the common ground upon which the organizational concerns of the firm (or the estate) and the relief system for the poor lay. In fact, insubordination or failure to comply with workshop production rules was presented as a breach of contract without notice, and as such was liable to sanctions under criminal law. ${ }^{40} \mathrm{Crim}-$ inal-law control over labor was aimed at reducing both turnover and supervision costs, ${ }^{41}$ and limiting turnover was also one of the main aims of the Poor Laws. This link is crucial in the broad history of labor and labor institutions in Britain, as well as in the particular history we are dealing with here, that is, the origin of the Panopticon. In both cases, labor surveillance was at center stage. The Old Poor Law (which evolved through a series of statutes, culminating in the Act of Elizabeth, in 1601) required individual parishes to relieve their own poor and set able-bodied paupers to work. By the mid-seventeenth century, many parishes were using the Poor Law to shelter both children and the aged in hospitals and to employ those capable of labor in workhouses or with local employers. ${ }^{42}$ Around the end the seventeenth century, a number of urban workhouses were set up to train poor children while profiting from pauper labor. In this context, the distinction between vagrant and poor was crucial; a poor person without employment or residence became a vagrant and was submitted to penalties similar to those imposed on "ordinary workers" (that is, servants). "Vagrancy" described a condition in which an able-bodied person without work or other means of subsistence was to be submitted to corporal punishment and returned to his parish.

In the seventeenth and eighteenth centuries, the English Poor Law system was distinctive in Europe to the extent that it embodied a nationally organized, comprehensive, and publicly regulated approach to relief. ${ }^{43}$ However, in the mid-eighteenth century, the workhouses and Poor Laws began to be disparaged as inefficient and expensive. A parliamentary enquiry of 1776 revealed the existence of 1,970 workhouses holding a total of 90,000 paupers. In most cases, pauper labor did not meet the general running costs of a workhouse. This situation became all the more alarming when the estimated poor rates increased sharply from $£ 700,000$ in 1700 to $£ 1,500,000$ in $1776 .{ }^{44}$ Increasing enclosure of the countryside greatly contributed to this rise by cutting off access to the land. ${ }^{45}$

In 1782, a bill known as Gilbert's Act was adopted that allowed neighboring parishes to group together for Poor Law purposes and set up poorhouses under a board of guardians. This occurred just around the time when Samuel and Jeremy Bentham moved to Russia, and they closely followed this debate. The Krichev experience confirmed for Jeremy the 
necessity of reforming both the workhouses and the Poor Laws. The passage of this bill also explains why critiques of poor laws and the Panopticon project emerged concurrently in public debates of the mid-1780s. Only the "indigent" and disabled were supposed to receive relief, Jeremy Bentham argued, while the "ordinary poor" had to settle down and find an employment. ${ }^{46}$

At the same time, attempts were made to increase the efficiency of the entire system by rational organization, that is, by supervision of the workhouses. This made the boundary between free and unfree labor even more tenuous. Servants, wage earners, the poor, criminals, slaves, and serfs all had to respond to common general principles of utility and efficiency, "no matter how different, or even opposite the purpose: whether it be that of punishing the incorrigible, guarding the insane, reforming the vicious, confining the suspected, employing the idle, maintaining the helpless, curing the sick, instructing the willing in any branch of industry, or training the race in the path of education: In a word, whether it be applied to the purposes of perpetual prisons in the room of death, or prisons for confinement before trial, or penitentiary houses, or houses of correction, or work-houses, or manufactories, or mad-house, or hospital, or schools." 47

During the 1770s and the 1780s, anti-slavery activity intensified at the same time as a profound transformation in English attitudes toward the poor was taking place. These issues remained connected until, under pressures of widespread hostility toward both coerced labor and public relief, the apprenticeship system of slavery was introduced in the colonies in 1833-34 and a new Poor Law was passed in $1834 .{ }^{48}$ Following the suggestions of Bentham and others since the 1780s, reformers made a sharp distinction between the "natural poor" and the indigent (unable to work), and only the latter were permitted to benefit from poor relief. The same principles were applied to former slaves, who qualified as vagrants if they were not settled and employed.

To sum up, in turn-of-the-century Britain, the barrier between free and unfree labor was movable and negotiable, and it was conceived through categories quite different from those of today. In intellectual and public debates of the time, poor relief, the general condition of labor, and the question of slavery and serfdom were tightly linked. More than just "efficiency" was at stake (hence Adam Smith's and others' assertions that wage labor was more productive and efficient that forced labor); public order, vagrancy, and social welfare were equally important. It was not only slaves or the indentured who could have been the "runaways," but also serfs, servants, and apprentices. All of these groups were subject to sanctions of criminal law, in addition to civil law. The material and living conditions of 
free workers and servants were not necessarily better than those of serfs. From this viewpoint, therefore, differences in labor control and labor rights in Britain and Russia were a matter not of opposite notions, but of degree. Russia remained at one extreme of a common spectrum and not "beyond the line." With this in mind, I now turn to explain the fate of Jeremy Bentham's ideas on labor organization in the two countries.

\section{The Fate of Bentham's Panopticon: Labor Organization in Nineteenth-century Britain and Russia}

The Bentham brothers' plan to build a Panopticon in Krichev was met with favor by Potemkin, who was himself an enthusiast for ideas of labor optimization through the division of labor and enhanced supervision. This kind of Westernizing utopia, born from a mixture of coercion, science, and control, was a cornerstone of the reform plans of Catherine and her close collaborators. One of those collaborators was Potemkin, and another, Mikhail Tatishchev, had been in close contact with the Bentham brothers in London during the late 1760s, when he was involved in drafting Catherine's Nakaz ("Instruction") for the Legislative Commission and her new legal code. ${ }^{49}$ But while Bentham and his brother were originally motivated by a goal of controlling English foremen, Potemkin and the other Russian reformers came to see the project as a way to control serfs. The ambition to combine the division of labor with surveillance had a profound influence on one of the Bentham brothers' intimates in Russia, Nikolai Mordvinov. ${ }^{50}$

Nonetheless, the shared project of the Bentham brothers and Potemkin-to build a Panopticon on Potemkin's estate-fell through, because he sold the estate in 1787, which led Jeremy Bentham to return to England. Jeremy's contribution was to generalize his brother's project, ${ }^{51}$ making it applicable outside of Russia and incorporating it into his general approach to the organization of labor. He first extended the idea of an office of labor surveillance to prisons, then to schools, and finally to hospitals-and to all situations in which the problem of supervision arose..$^{52}$

Jeremy Bentham's starting point, to be sure, was an idea that resonated powerfully with his sense of morality: that it was better to put prisoners to work than let them vegetate and that such an approach would facilitate prisoners' progressive reintegration into society. Yet he could not resist straying from this rationale and returning to the utilitarian calculation that new forms of surveillance and organization could and should make prison labor profitable.$^{53}$ From there it was but a short step to start thinking about ways to maximize prisoner productivity. At first he proposed to rationalize prisoners' diet: they should not become malnourished or else 
their productivity would diminish. Yet Bentham thought mostly in terms of amounts and was not embarrassed to suggest that prisoners be given spoiled food mixed with fresh food (within reasonable limits, to avoid abrupt drops in labor productivity) ${ }^{54}$ He seemed excited at the thought that prisoners could be made to work fifteen hours and more without their wanting to leave their jobs, as wage laborers did.

Bentham was not exceptional in advancing these ideas. For example, his friend Admiral Jonas Hanway, founder of the Magdalen Hospital, applied the same principles to the Navy and workhouses. He transformed the prison into a place of highly productive forced labor and then exported that model to the working world at large. ${ }^{55}$ To discipline wage labor in ways similar to forced labor was thus a widespread goal in nineteenth-century Britain, and the Panopticon was only one of many proposed methods.

It is here that the gap between Britain and Russia narrows. When Samuel and then Jeremy went to Russia, the question of labor surveillance was being discussed in relation to rural estates, but also, as in Britain in these same years, to poor relief. Before the reign of Catherine the Great, the aged and infirm were supported in parish almshouses, and able-bodied vagrants were frequently conscripted to factories, mines, or the military. In 1775 an edict created the Offices of Public Welfare (Prikazy obshchestvennogo prizreniia) and proposed establishing workhouses under the authority of local police to punish the lazy and enable the needy to support themselves. The first workhouse (Rabotnyi dom) was built in Moscow in 1782, the same year Samuel Bentham moved to Siberia and that Gilbert's Act was adopted in Britain. This was the culmination of a broader movement started in Russia in the mid-1770s, which coupled Catherine's ambition of urbanization and modernization of the country with police control over migrants and with "Russian pity." 56 This movement received a boost from Bentham's Panopticon theory. In 1806, Samuel Bentham returned to Russia and convinced Alexander I to build a "Panopticon School of Arts" in Saint Petersburg. ${ }^{57}$ During the years that followed, the tsar ordered the construction of a number of such buildings devoted to administration and education. ${ }^{58}$ At the same time- and with the tsar's encouragement-more and more of Bentham's works were translated into Russian. However, in Russia as in Europe, the end of the Napoleonic Wars brought a backlash against the reformers. Various Russian authors denounced the conditions of the workers in Europe and showed that the landowners treated and fed their serfs much as they did their horses. ${ }^{59}$

At least at this level of generality, the Russian leaders' sense of distance from Bentham was shared by almost all nineteenth-century Russian intellectuals and economists, who relentlessly criticized a utilitarianism 
that they contrasted with Russian empathy and communal principles. The interests of the intellectuals and the autocracy converged in affirming a Russian uniqueness that they identified with both the spirit of community and the rejection of consumerism and hedonism.

While Bentham's utilitarian ideas were met with a mixed reception, his theories on prisons and labor discipline found enthusiastic adherents among some "reformers," including Nikolai Mordvinov, a friend of Samuel Bentham and president of the Free Imperial Economic Society between 1823 and 1840. Mordvinov was one of the noble landowners who-starting in the 1780s-had issued more and more written instruktsii designed to improve the nobles' control over their estates and especially over the labor of their serfs. He had known the Bentham brothers since the 1780s, and his aims and opinions were influential on Jeremy Bentham's thought. Conversely, Mordvinov was deeply influenced by Bentham's ideas and his system of modeling the division of labor on a well-organized prison. In 1807 Samuel Bentham was back in Russia, and he brought Mordvinov writings by his brother, who at that time considered Samuel one of his best disciples. ${ }^{60}$ After the Napoleonic Wars, in 1818-19, it was Mordvinov's turn to go to England and present Jeremy with his draft project for a representative assembly in Russia. ${ }^{61}$ At this time, Mordvinov insisted, like Bentham, that more surveillance and control over the serfs was necessary to boost productivity. ${ }^{62}$

Finally, Mordvinov intervened in the reforms of the exile system, which were implemented in 1822. As Andrew Gent has recently shown, there was an intersection of the system of punishment, exile to Siberia, and colonization. ${ }^{63}$ However, following my argument-and as the involvement of Mordvinov testifies-these reforms would have not become prominent were it not for the experiences of Samuel Bentham in Siberia, the increased circulation of Western ideas on colonization, and their link with Benthams' utopia. It is therefore interesting from a historiographical perspective and ultimately surprising to hear the enthusiastic praise later expressed for the liberal spirit of Mordvinov, that "great liberal" who has supposedly been unjustly forgotten. ${ }^{64}$

This approach was the opposite of what Russian reformers and economists had advocated at the beginning of the century, having been inspired by Smith and his invisible hand to show that free labor was more profitable than serfdom. According to Mordvinov, productivity gains were unlikely to be achieved by granting greater freedoms, for which he said the serfs were not ready. But gains could be made, he claimed, through stricter supervision and organization of their work. The inspiration came from Bentham rather than Jean-Baptiste Say. This was the context in 
which the new military colonies attempted to reconcile serfdom with new agricultural methods, and military management with settlement on the land. From the end of the Napoleonic Wars to the mid-1830s, top leaders, as well as many Russian economists and agronomists, supported the colonies, which they believed were capable of reconciling order and productivity, liberty and coercion. This experiment, at once economic, political, and social, affected 750,000 people, but the results were meager, and the military colonies were abandoned after being shaken by riots in the early 1830s. ${ }^{65}$

Meager results did not stop noble proprietors from implementing measures advocated by agronomists, albeit with coercive methods. We have already seen the example of Mordvinov. A similar case was that of Pavel Kiselev, the minister of state domains, who imposed corporal punishments and fines on peasants who resisted changes in the organization of labor or the extension of the potato fields that were figured into Kiselev's plans as a protection against future bad harvests. The new measures he introduced sparked peasant riots that destroyed the potato fields ${ }^{66}$ However, though this approach of forcibly introducing changes into the organization of agricultural labor was dominant, it was not universal, and scholars have shown that landowners in fact achieved varying degrees of success in introducing new agricultural methods. ${ }^{67}$ Many of their findings on both the microeconomic level of the estate and the regional level highlight the rising productivity of noble estates in the first half of the nineteenth century. ${ }^{68}$ In general, the "instructions" issued by noble landlords with increasing frequency from the last quarter of the eighteenth century addressed the same concern as did Bentham: how to improve labor organization by giving greater responsibility to supervisors rather than peasants. ${ }^{69}$

We can thus conclude that the relationship between coercion and reform, free labor and forced labor, was no less complex in Russia than in the West. In Europe, Bentham inspired those who wished to rationalize society through supervised labor, but in Russia not everyone followed his approach, for negotiated reforms did indeed take place, most notably at some noble estates. This helps to explain the conclusion drawn by recent economic historiographers: whether in agriculture, proto-industry, or industry proper, the data shows that serfdom was not synonymous with either demographic decline ${ }^{70}$ or arrested economic or technological development. ${ }^{71}$ Economic growth in the first half of the nineteenth century-its momentum as well as its limitations - rested on the laws of serfdom, an institutional structure that formed not only a system of constraint, but a basis for mutual negotiation. ${ }^{72}$ 


\section{Conclusion}

Notions and practices of labor vary over time and can hardly be compared in terms of universal and ahistorical notions of free and unfree labor. Otherwise we would find it very difficult to explain why Bentham's Panopticon was conceived on the basis of his experiences in Russia. Bentham's utopias were embedded in the context of the late eighteenth to early nineteenth centuries, and the clear-cut opposition it drew between the free labor of the servant and the unfree labor of the slave was an attempt-one made by several "liberal" British intellectuals of that timeto halt slavery while at the same time preserving the statuses of servant and master. The poor were in turn redefined in accordance with whether or not they were willing to work, and, if they were, they entered the category of servants. Bentham's Panopticon project reveals his ambition to apply the order and social control of labor conceived for Russian estates and British prisons to the "free" labor of skilled wage earners, precisely at the moment when the latter were escaping their former status as servants or apprentices. The Poor Laws, the Master and Servant Acts, slavery, and the legal status of the Russian peasantry all came under attack during the last quarter of the eighteenth century. In Britain, this culminated in the 1830s reforms that clearly distinguished the "real poor" from vagrants, put slaves under apprenticeship, and introduced new vagrancy laws. At the same time, in Russia, tsarist elites encouraged changes in the legal status of the peasantry through reforms that, although partial, initiated a general process of peasant emancipation.

Both systems declined along similar paths. Serfdom collapsed at the same time that the Master and Servant Acts began to face increasing criticism in Britain and the colonies. ${ }^{73}$ And even though the Poor Laws system was abandoned in 1844 , it was not until 1875 that criminal-law sanctions backing labor contracts were done away with. Genuine measures to protect laborers, including measures pertaining to occupational, industrial accidents, were not adopted until the twentieth century. How can we explain these similarities? Beyond the circulation of ideas we have just discussed, were there common institutional and economic paths in both Europe and Russia?

The next chapters will address these questions.

\section{Notes}

This chapter is a revised version of my article "The Traveling Panopticon: Labor Institutions and Labor Practises in Russia and Britain in the Eighteenth and Nineteenth Centuries," Comparative Studies in Society and History 51, 4 (2009): 715-41. I would like to 
express my gratitude to the journal and Cambridge University Press for granting permission to reproduce it here.

1. Foucault, Discipline and Punish. Anne Brunon-Ernst has recently challenged the idea that Foucault understood the Panopticon in terms of mere surveillance. See her "When Foucault Reads Bentham," paper presented at Annual Meeting of the Law and Society Association, Berlin, 25 July 2007, http://www.allacademic.com/meta/pl78059_index.html.

2. My sources are contemporary works published in Britain, Russia, and other European countries, and include legal texts such as laws, case law, and jurisprudence, as well as Russian archival sources. The latter are mostly estate archives and local court litigations available at the Russian State Archives of Ancient Acts (RGADA) and the Central State Historical Archive in Moscow (TsGIAM).

3. Evgeniia P. Zakalinskaia, Votchinnye khoziaistva Mogiliovskoi gubernii vo vtoroi polovine XVIII veka [Noble estates in the province of Mogilyov during the second half of the eighteenth century] (Mogilyov: Mogilevskii oblast' Kraeved. muzei, 1958), 27, 34.

4. A ropewalk was a long, straight, narrow lane or a covered pathway, where long strands of material were laid before being twisted into rope. Rope was essential in sailing ships, and the standard length for a British naval rope was 1,000 feet (305 meters).

5. Montefiore, "Prince Potemkin."

6. Jeremy Bentham, The Correspondence of Jeremy Bentham, 12 vols. Timothy L. S. Sprigge, ed. (London: Athlone Press, 1968-2006), v. 2:504; The Works of Jeremy Bentham, 11 vols., John Bowring, ed. (Edinburgh: William Tait, 1838-1843), v. 10:161; Werrett, "Potemkin and the Panopticon"; Christie, The Benthams in Russia; Christie, "Samuel Bentham and the Western Colony"; Montefiore, "Prince Potemkin."

7. Bowring, Works of Jeremy Bentham, 10:161.

8. Bentham, Correspondence, 3:498.

9. Ibid., 503, 509-12.

10. Bowring, Works of Jeremy Bentham, 4:41.

11. Jeremy Bentham, The Panopticon Writings, Miran Bozevic, ed. (London: Verso, 1995), letter 1.

12. Jeremy Bentham, "Panopticon": or, the Inspection-House; containing the idea of a new principle of construction applicable to any sort of establishment, in which persons of any description are to be kept under inspection; and in Particular to Penitentiary-houses, Prisons, Houses of industry, Workhouses, Poor Houses, Manufacturies, Madhouses, Lazarettos, Hospitals, and Schools; with a plan of management adopted to the principle; in a series of letters, written in the year 1787, from Crechoff in White Russia, to a friend in England, 2 vols. (London: T. Payne, 1791).

13. Werrett, "Potemkin and the Panopticon."

14. Blum, Lord and Peasant, Tracy K. Dennison, "Did Serfdom Matter? Russian Rural Society, 1750-1860," Historical Research 79, 203 (2003): 74-89.

15. Michael Confino, Domaines et seigneurs en Russie vers la fin du XVIIIe siècle: Étude de structures agraires et de mentalités économiques (Paris: Institut d'études slaves de l'Université de Paris, 1963), 39ff.; Konstantin V. Sivkov, "Nakazy upraviteliiam XVIII v. kak istochnik dlia istorii sel'skogo khoziaistva v Rossii" [Eighteenth-century estate regulation as a source for the history or rural economy in Russia], in Sbornik akademika B. D. Grekova ko dnin 70-letiia (Moscow: Nauka, 1952), 241-46; Konstantin V. Sivkov, "Istochniki po istorii sel'skogo khoziaistva Evropeiskoi Rossii vo vtoroi polovine XVIII veka" [Sources of the history of agriculture of European Russia during the second half of the eighteenth century], in Problemy istochnikovedeniia [Problems of historiography] VIII (Moscow: Nauka, 1959); Nikolai L. Rubinshtein, Sel'skoe khoziaistvo Rossii vo vtoroi polovine XVIII v. [Russian agriculture during the second half of the eighteenth century] (Moscow: Nauka, 1957); Melton, "Enlightened Seigniorialism," 675-708.

16. Confino, Domaines et seigneurs, 40. 
17. Confino, Domaines et seigneurs; Melton, "Enlightened Seigniorialism"; Rubinshtein, Sel'skoe khoziaistvo; Sivkov "Istochniki po istorii."

18. Viktor A. Aleksandrov, Sel'skaia obshchina v Rossii, XVIII-nachalo XIXe veka [The agrarian commune in Russia, eighteenth and early nineteenth centuries] (Moscow: Nauka, 1976).

19. Confino, Domaines et seigneurs.

20. Raeff, The Well-ordered Police State.

21. Confino, Domaines et signeurs. For examples, see: Mikhail Golitsyn, "Polozhenie dlia krest'ian Efremovskoi votchiny sela Mikhailovskogo derevni Varvarovki 1839 g." [The conditions of peasants of the estate Efremovskii, village of Varvarovki, in 1839], in Materialy dlia istorii votchonnogo upravleniia v Rossii, ed. M. V. Dovnar-Zapol'skii (Kiev: tipography Imperatorskogo Universiteta, n.d.), 276-80.

22. Bush, Serfdom and Slavery.

23. Confino, Domaines et seigneurs, 44; T. I. Kliengstaedt, "Iz'iasnenie sposoba k pooshchreniiu zemledel'tsov k trudoliubiiu" [Encouraging attitudes toward labor of rural populations], Trudy IVEO XVI (1770): 248.

24. Tracy Dennison and Sheilagh Ogilvie, "Serfdom and Social Capital in Bohemia and Russia," Economic History Review 60, 3 (2007): 513-44.

25. See, for example, Confino, Domaines et seigneurs; Melton, "Enlightened Seigniorialism," 702-4; and the special issue of Istoricheskie zapiski 37 (1951). See also Rodney Bohac, "Everyday Forms of Resistance: Serf Opposition to Gentry Exactions, 1800-1861," in Peasant Economy, Culture, and Politics of European Russia, 1800-1921, ed. Esther Kingston-Mann and Timothy Mixter (Princeton: Princeton University Press, 1991), 230-60; Wirtschafter, Structures of Society.

26. Police archives reproduced in Materialy dlia istorii krepostnogo prava v Rossii: Izvlecheniia $i z$ sekretnykh otchetov ministerstva vnutrennykh del za 1836-1856 gg [Materials for the history of serfdom in Russia: elements from the secret reports of the ministry of the interior ]. (Berlin: Behrs Buchhandlung, 1873). See also, Petr Andreevich Zaionchkovskii, Otmena krepostnogo prava v Rossii, 3rd ed. (Moscow: Izd-vo Kniga, 1968), and its English translation: The Abolition of Serfdom in Russia, ed. and trans., Susan Wobst (Gulf Breeze, FL: Academic International Press, 1978).

27. Confino, Domaines et seigneurs; David Moon, The Abolition of Serfdom in Russia, 17621907 (New York: Longman, 2001).

28. R. Vorontsov, "O sposobakh k ispravleniiu sel'skogo domostroitel'estva," (The methods for studying agrarian family units) Trudy IVEO 5 (1765): 1-13.

29. The archive of this estate is in RGADA, fond 1287 Sheremetevy, opis' 3, chast' 2. On this, see: Wirtschafter, Social Identity; Janet Hartley, "Catherine's Conscience Court-An English Equity Court?" in Russia and the West in the Eighteenth Century, ed. A. G. Cross (Newtonville, MA: Oriental Research Partners, 1983), 306-18. .

30. Indova, "Instruktsiia kniazia," 460.

31. Confino, Domaines et seigneurs.

32. Christie, "Samuel Bentham and the Western Colony."

33. Bentham, Principles, ch. 2, on slavery, par. 3310; Bowring, Works of Jeremy Bentham, v. 1.

34. David Brion Davis, The Problem of Slavery in the Age of Revolution, 1770-1823 (New York: Oxford University Press, 1999), 353-56.

35. Jean-Baptiste Say, Cours d'économie politique (Brussels: Meline, Cans et Compagnie, 1843), 522.

36. Deakin and Wilkinson, The Law of the Labor Market, 45.

37. Jeremy Bentham, Principles of Morals and Legislation, ch. 43, sec. 1, par. 1433; Bowring, Works of Jeremy Bentham, v. 1.

38. Ibidem, par. 1472 and 1516 .

39. par. 1518 . 
40. George J. Barnsby, Social Conditions in the Black Country, 1800-1900 (Wolverhampton, England: Integrated Publishing Services, 1980).

41. Michael Huberman, Escaping from the Market: Negotiating Work in Lancashire (Cambridge: Cambridge University Press, 1996).

42. Kathryn Morrison, The Workhouse: A Study of Poor-law Buildings in England (Exeter: Royal Commission on the Historical Monuments of England, 1999); M. A. Crowther, The Workhouse System, 1834-1929: The History of an English Social Institution (Athens, GA: Georgia University Press, 1981).

43. Deakin and Wilkinson, Law of the Labor Market, 114.

44. Reports from Committees of the House of Commons, 1st. ser., IX, 1774-1802: 297-538. See Crowther, The Workhouse System, 29.

45. See, for example, J. R. Wordie, "The Chronology of English Enclosure, 1500-1914," Economic History Review 36 (1983): 483-505. For classical interpretations, see Karl Polanyi, The Great Transformation (Boston: Beacon Press, 1957, orig. 1944); and Eric Hobsbawm, Industry and Empire (Middlesex: Penguin, 1969).

46. Jeremy Bentham, "Essay II. Fundamental Positions in Regard to the Making Provision for Indigent Poor," in Essays on the Subject of the Poor Law (1796), reproduced in The Collected Works of Jeremy Bentham Writings on the Poor Law, ed. Michael Quinn (Oxford: Clarendon Press, 2001), 39.

47. Bentham, Panopticon Writings, letter 1. See fn. 13.

48. On this link, see Davis, The Problem of Slavery, 356. On the apprenticeship system for slaves, see Drescher, Capitalism and Antislavery; Engerman, Terms of Labor.

49. Anthony C. Cross, By the Banks of the Neva: Chapters from the Lives and Careers of the British in Eighteenth-century Russia (Cambridge: Cambridge University Press, 1999).

50. Ibid.

51. Bentham, Correspondence, 4:40.

52. The Panopticon Writings were systematized and partly abridged in five editions of Bentham's works. The cited edition contains letters from Russia, as well as the final published version of the Panopticon. On this subject, see Philip Schofield, Catherine Pease-Watkins, and Cyprian Blamires, Rights, Representation, and Reform: Nonsense Upon Stilts and Other Writings on the French Revolution (Oxford: Clarendon Press, 2002); and Catherine Pease-Watkins, "Bentham's Panopticon and Dumont's Panopticon," University College London Bentham project, www.ucl.ac.uk/bentham-project.

53. J. Bentham, The Rationale of Punishment (1830), repr. in Bowring, Works of Jeremy Bentham, 1:439.

54. Semple, "Foucault and Bentham," 130-131.

55. Ibid., 85-86.

56. Joseph Bradley, "The Moscow Workhouse and Urban Welfare Reform in Russia," Russian Review 41, 4 (1982): 427-44; Georg Shvittau, Trudovaia pomoshch v Rossii [Labor assistance in Russia], 2 vols. (Petrograd: tip. A. Kollias', 1915).

57. M. S. Bentham, "Description of the Panopticon at Okhta," Mechanic Magazine (31 Mar. 1849), cited in Werrett, "Potemkin and the Panopticon," 11.

58. Bentham, Correspondence, 8:224.

59. See Kingston-Mann, In Search of the True West, 69.

60. Bentham, Correspondence, 7:563-67.

61. Bentham, Correspondence, 10:542.

62. Nikolai S. Mordvinov, "Nekotoriia soobrazheniia po predmetu manufaktur v Rossii i o tarife" [Some observations on Russian manufactures and the tariffs], Zhurnal Departamenta Gosudarstvennoi ekonomiki 14 (30 Dec. 1815): 282-303, 345-388. On Mordvinov, see A. M. Gnevushev, Politiko-ekonomicheskie vzgliady gr. Mordvinova [Mordvinov's political and economic orientations] (Kiev: M. V. Dovnar-Zapol'skii, 1904). 
63. Andrew Gentes, Exile to Siberia, 1590-1822: Corporal Commodification and Administrative Systematization in Russia (London: Palgrave, 2008). See also Abby Schrader, Languages of the Lash: Corporal Punishment and Identity in Imperial Russia (DeKalb: Northern Illinois University Press, 2002).

64. See, for example, Basil Dmytryshyn, "Admiral Nikolai Mordvinov: Neglected Russian Liberal," Russian Review 30, 1 (1971): 54-63; and more recently, Susan P. McCaffray, "What Should Russia Be? Patriotism and Political Economy in the Thought of N. S. Mordvinov," Slavic Review 59, 3 (2000): 572-96.

65. Richard Pipes, "The Russian Military Colonies," Journal of Modern History 22, 3 (1950): 205-19.

66. Aleksandrov, Sel'skaia Obshchina; Peter Kolchin, "In Defense of Servitude: American Pro-slavery and Russian Pro-serfdom Arguments, 1760-1860," American Historical Review 85, 4 (1980): 809-27; Walter M. Pintner, Russian Economic Policy Under Nicholas I (Ithaca: Cornell University Press, 1967).

67. Confino, Domaines et seigneurs; Hoch, Serfdom and Social Control.

68. Melton, "Enlightened Seigniorialism"; Ivan D. Koval'chenko, Russkoe krepostnoe krest'ianstvo $v$ pervoi polovine XIX $v$. [The Russian serf economy during the first half of the nineteenth century] (Moscow: Nauka, 1967). .

69. U. Karpovich, Khoziaistpennye opyty tridtsatiletnei praktiki $i$ nastavlenie dlia upravleniia imeniami [Practices of the three-fields system and the orientation for the direction of domains] (Saint Petersburg: Tip. I. Vorob'eva, 1837).

70. Steven Hoch and Wilson Augustine, "The Tax Census and the Decline of the Serf Population in Imperial Russia, 1833-1858," Slavic Review 38, 3 (1979): 403-25; and Steven Hoch, "Did Russia's Emancipated Serfs Really Pay Too Much for Too Little Land? Statistical Anomalies and Long-tailed Distributions," Slavic Review 63, 2 (2004): 247-74.

71. For a recent synthesis concerning the agricultural economy, see David Moon, The Russian Peasantry, 1600-1900 (London: Longman, 1999). For a discussion of the connection between serfdom and the absence of technological innovation, particularly in the metallurgical industry, see Thomas Esper, "Industrial Serfdom and Metallurgical Technology in Nineteenth-century Russia," Technology and Culture 23, 4 (1982): 583-608.

72. Hoch and Augustine, The Tax Census; Vladimir M. Kabuzan, Narodonaselenie Rossii $v$ XVIII-pervoi polovine XIXe v. [The Russian population from the eighteenth through the first half of the nineteenth century] (Moscow: Izdatel'stvo Akademii Nauk SSSR, 1963).

73. Huberman, Escaping from the Market; Robert J. Steinfeld, Coercion, Contract, and Free Labor in the Nineteenth Century (Cambridge and New York: Cambridge University Press, 2001); Deakin and Wilkinson, Law of the Labor Market, Willibald Steinmetz, ed., Private Law and Social Inequalities in the Industrial Age (Oxford: Oxford University Press, 2000). On the evolution of Britain's rules on labor health, see Peter W. Bartrip and Sandra Burman, The Wounded Soldiers of Industry: Industrial Compensation Policy, 1833-1897 (Oxford: Oxford University Press, 1983); Peter W. Bartrip, Workmen's Compensation in Twentieth-century Britain: Law, History, and Social Policy (Brookfield, Vt. and Avebury: Aldershot, 1987); E. P. Hennock, British Social Reform and German Precedents: The Case of Social Insurance, 1880-1914 (Oxford: Oxford University Press, 1987). 


\section{The Architecture of Bondage} Slaves and Serfs in Central Asia and Russia

This open access library edition is supported by Knowledge Unlatched. Not for resale. 
This open access library edition is supported by Knowledge Unlatched. Not for resale. 
CHAPTER 3

\section{Slavery AND Bondage in Central Asia and Russia FROM THE FOURTEENTH TO THE Nineteenth Century}

\section{Introduction}

Serfdom in Russia can hardly be understood when studied outside the context of the evolution of forms of bondage in Muscovy and Central Asia between the fourteenth and the early eighteenth century. As a whole, the history of bondage in Russia and Eurasia provides useful insights into the link between overall forms of bondage and war captives, on the one hand, and slavery, on the other. Two main sources of enslavement are usually mentioned in studies of ancient, medieval, and modern slavery: debt (widely conceived as a form of individual and/or social obligation) and capture by war parties or belligerent armies. Roughly speaking, the first source is specific to a given society, while the second is generated by a party transgressing territorial boundaries. ${ }^{1}$

This taxonomy requires some important qualifications. For example, war captives may be offered for ransom, but they may also be sold as slaves. Sale of captives within the internal market of the victorious war party was quite widespread; however, this shift required the agreement of the leaders of the clan or state. The boundary between a war captive and a slave was therefore flexible and depended on the relative power of military commanders, political leaders, slave brokers, and slave owners in negotiating among themselves the disposition of war captives. In this respect, slaves and captives in ancient Rome or modern Africa are quite different phenomena. 
In turn, debt and "obligated" slaves cover a much wider and debated category, extending from debt bondage to voluntary or involuntary submission, and finally to pawnship. Enslavement by consent occurred frequently in Africa, India, China, and Southeast Asia. Such slavery was usually indigenous, and while it was prohibited by Islam and Western Christianity, it was acceptable to the Greek Orthodox Church, Hinduism, Confucianism, or Buddhism. ${ }^{2}$

In this respect, Russia and Eurasia provide a stimulating historical environment through which to discuss the appropriateness of the terminology used above and by which to determine whether envisioning the phenomena encompassed by such wording is historically warranted.

On these topics, available historiographies provide answers that can be sketched as follows: Russia constituted a peculiar historical case in which slavery was practiced on Russians themselves. Russia's backwardness in comparison to the West can be confirmed by the persistence of despotism and bondage. In turn, Oriental despotism went along with the long-term persistence of the nomadic powers in Central Asia, and ultimately, these features contributed to keeping Central Asia and Russia out of the world dynamics - namely the rise of capitalism in the West-and to the marginalization of these areas in the world economy.

Over the last several years, some aspects of these views have been revisited. Peculiar emphasis has been placed on the nomadic powers of Central Asia as long-term cultural, commercial, and political forces; to a certain extent, Eurasian history now has become a fresh topic, no longer necessarily associated with despotism, nomadic powers, and backwardness. In this view, war captives and domestic bondage are far from a symptom or source of backwardness and instability. Such a judgment is based upon the presumption of the superiority of free labor over bonded labor and of territorial states over pirates and nomads. ${ }^{3}$

A similar judgment orients the main interpretations of Russian forms of bondage resulting from capture in war. The existence of slavery in Russia is little known outside the circle of pre-Petrine Russia specialists, despite slavery's importance not only for Russian but also for global history, e.g., the link between slavery and serfdom; the relationship between the lengthy Russian history of bondage (most prominently slavery and serfdom) to the Gulag; and last but not least, bondage as testimony to the Mongol influence on Russia or, vice versa, as a response to European world expansion. Answers to these questions require careful analysis of slavery in premodern Russia, and such investigation must focus on war captives, domestic slaves, and bonded people in their historical definitions and overlapping. So who were they? 
A current historiography follows the main, if not sole, reference work in a Western language on Russian slavery, Richard Hellie's book Slavery in Russia, 1450-1725. ${ }^{4}$ Hellie considers the kholopy to have been slaves. He initially translated kholopstvo as bondage but later preferred the term slavery. Herbert Leventer objected to the latter translation, emphasizing that the status of Russian kholopy was not transferred to their children, that their servitude was temporary, and that they could accumulate and transfer property. He therefore thought that kholop corresponded instead to the English word servant. Hellie retorted that in Russian, kholop was a synonym for rab (slave), and that even if the conditions of the kholopy were different from those of slaves in the ancient world and in the Americas, they were perfectly compatible with those of other forms of slavery. ${ }^{5}$

This is actually quite a common problem met by everyone who has studied the forms of bondage and slavery: to what extent can we qualify different forms of bondage to different words and rules, among them "slavery"? The question has been raised for various forms of bondage in Africa, India, China, the Ottoman Empire, Latin America, Southeast Asia, etc. On the one hand, several scholars have stressed the existence of slavery in these various places, at different times. ${ }^{6}$ On the other hand, many other specialists on these areas have replied that local forms of bondage (and the related words to express them) cannot be translated as slavery insofar as these particular forms of bondage involved reciprocal obligations, voluntary submission, temporary bondage, and still other kindred phenomena that would seem to exclude them from being defined as slavery in a strict sense. ${ }^{7}$

One position minimizes the historical weight of transatlantic and Western colonial slavery in the Americas by lessening the perceived ubiquity of its oppressiveness, while the latter position stresses the historical specificity of forms of bondage and dependence and of the uniqueness of Western slavery. The stakes in these debates are high, as they possibly call for reparations from old European colonial countries and the United States to the countries from which slaves originated. Contemporary debates over the nature informal forced labor (i.e. Eastern European sex trade, African child soldiers, etc.) in the twenty-first century also grapple with historical definitions of slavery. ${ }^{8}$

Yet any general definition of slavery misses the point, that is, it does not acknowledge how different societies in different times identified legal status and labor conditions and assigned hierarchical duties, obligations, and, eventually, rights to the people in question. I prefer to adopt this last approach, which, in turn, does not avoid comparisons but, quite the 
contrary, seeks to identify multiple criteria for comparing labor conditions and legal status in different historical contexts.

Our investigation starts by looking at Russian words that express forms of legal bondage and then by trying to understand their social and institutional role by comparing legal texts and social practices. This investigation shows that the Russian language generated one single word (kholopstvo) to express bondage; however, at the same time, within this rubric, different forms and gradations of dependence existed, from debt bondage and self-sale into bondage to indenture and chattel slavery. This taxonomy reflected the fact that kholopstvo was a much less precise category or invariant legal status (as the term slavery connotes in Western language) than a spectrum of bondage-related phenomena, each of which was addressed specifically by statutory definitions and regulations and/or by contracts.

This situation was not unique to Russia: in African pawnship, for example, the major difference from Western slavery and other forms of African bondage and slavery was that ownership and transfer concerned the contract and not people. ${ }^{9}$ The same sort of argument can be made for Russian kholopstvo. To parallel recent debates about slavery, the critical issue is not whether any system of bondage was harsh or mild, but rather which conditions were exceptional and which were typical. ${ }^{10}$ In Russia, hereditary slaves comprised barely 10 percent of the kholopy (who in turn comprised 10 percent of the population), and they were mostly recorded to have lived in Novgorod in the aftermath of the oprichina (1565-72, when the Tsar Ivan IV split the state in two and ravaged much of it) and during the Time of Troubles (1598-1613, which ended with the establishment of the Romanov dynasty in place of the 700-year Riudrikid dynasty). All other contracts, as we will see, were limited in time or lasted until the death of the master. This difference certainly mattered, although more detailed empirical analyses would be required to determine the percentage of renewed contracts that ended up erasing this difference. At the same time, two major features differentiated these relationships from hereditary kholopstvo: a contract remained part of the legal status and, therefore, the condition of kholopstvo did not automatically transfer to children (even if this issue was not de facto impossible).

The second part of this chapter focuses on war captives. Unlike a kholop, a war captive often entered permanent slavery. They constitute a historically important element of normative and unusual political activity and even turmoil. Over centuries, if not millennia, war captives, pirates, and nomadic powers were the rules and not the exceptions in geopolitical and economic equilibriums. ${ }^{11}$ From the twelfth to the eighteenth century, captives and slaves were part of the common world for the Mongols, 
Berbers, Ottomans, Chinese, and European powers. All of them took part in raids and the trade in captives, and all made use of slaves. This also implies that the Eurasian history of slavery cannot confirm the clear-cut opposition between slave and captive, on the one hand, and nomadic and territorial powers, on the other. Theorists of state-building ${ }^{12}$ as well as economic historians ${ }^{13}$ persistently oppose predatory units to centralized states. The Mongols are placed in the first category, Europe the second. The history of war captives and slaves leads us to adopt a different approach, close to that of those who have recently revisited the history of the steppes and, more generally, the opposition between national states and nomadic and predatory powers. ${ }^{14}$

Sources for studying these problems are as numerous as they are scattered. Regarding kholopy, the Russian archives provide whole series of contracts, civil statuses, and other litigations. Partially exploited by Iakovlev, Paneiakh, and Hellie, these sources provide a complete picture of the phenomenon. The kabal'nye knigi (i.e., the kholopy registration books) are particularly valuable, as are the records of the kholopy prikaz, settled in $1571 .{ }^{15}$ Contracts are also available in the Saltikov-Shedrin library.

The sources for studying war captives raise distinct problems, since so much of the paperwork has been lost and what has survived is in Middle-Russian script. The kholopy registers introduced in the sixteenth century and diplomatic sources provide some information; ${ }^{16}$ however, despite official rules, war captives were not systematically recorded, and therefore their real number must be substantially greater than what extant records tell us. We also lack sources from the Central Asian powers. ${ }^{17}$

This lacuna does not apply to the other important powers in the area under study, namely the Byzantine Empire, Venice, Genoa, and, later on, the Ottoman Empire, for these polities left an important archival legacy on war captives and the Eurasian slave trade. Ottomanists have already provided important studies on the market for slaves between Crimea, Russia, Central Asia, and the Ottoman Empire, in particular in the seventeenth through nineteenth centuries; ${ }^{18}$ historians of medieval and early modern Venice and Genoa have also provided some remarkable studies. Sources in Genoa and Venice include a few in Latin, but more in premodern Italian. Much of our knowledge about trade in Caffa, on the Crimean coast, is derived from the commercial deeds and contracts drawn up between 1128 and 1290 by the Genoese notary Lamberto di Sambuceto, ${ }^{19}$ although a precise date for the foundation of the Genoese colony there cannot be given. The first historical fact relating to Caffa in the Genoese chronicles is the dispatch of three vessels in 1289 by the consul of the port, Paolino Doria, to the aid of Tripoli. ${ }^{20}$ 


\section{Kholopy: Slaves, Serfs, or Indentured Servants?}

We have already mentioned the debate between Hellie and Leventer about translating kholop as slave. Such a translation is partly justified by the fact that when Peter the Great abolished this status in 1725, documents associated the kholop with a slave $(\mathrm{rab})$. This association of ideas dates from the early eighteenth century and occurred in the special context of the reforms of Peter the Great. At the time, insofar as slavery in the strict sense was prohibited, the word rab designated either a former slave, a slave mentioned in the Bible, or the symbolic relationship that the nobles maintained with the tsar. ${ }^{21}$ In fact, kholop meant "the subject of," and could be used referring to the tsar or any superior Russian political authority; this word was used in particular for Muslims and Tatars. ${ }^{22}$ In turn, the meaning of rab changed over time. Iakovlev thinks it was of Turkish origin and was used to designate Mamluk slaves from Africa, who were distinct from slaves originating from Central Asia and Eastern Europe. At the same time, in the southern part of the future Rus', the word rab referred to Cumans and Pechenegs. Notably, since the twelfth century, the word raba was used for a kholop's wife in Russian legal and common language. ${ }^{23}$ However, any free person who married a kholop was subject to the legal constraints applying to his or her spouse ("po rabe kholop, po kholopu rabe"). ${ }^{24}$ Even more important, the relationship between a kholop and his wife was associated with that between the kholop and his master, the rab and his master, and a son and his father. In all these cases, a mutual although hierarchical relation (of dependence) was established. Children, wives, and kholopy had limited but existing rights in relation to their "masters" (this category being inclusive of husbands and fathers). ${ }^{25}$

Let us try to grasp the meaning and content of the word kholop. ${ }^{26}$ According to Iakovlev, the word kholop derived from a Polish word that was associated with war captives since the eleventh century, in common Eastern Slavic and later in Russian. ${ }^{27}$ This is extremely important, as it testifies to the common origin of war captives and other bonded people. The word kholop then entered the Russkaia Pravda, a collection of legal acts that was first compiled in 1016 and put together in its near final version during the mid-twelfth century. ${ }^{28}$ Three main origins of slavery were listed there: accepting work associated with a slave; marrying a slave; or selling oneself into slavery. In the twelfth-century version of the Russkaia Pravda, the general category of kholopy was already highly differentiated and ranged from full kholopstvo (obelnyi kholop) ${ }^{29}$ to indentured servant $\left(\right.$ zakup). ${ }^{30}$ All of these categories had legal personality and rights. ${ }^{31}$ 
Indeed, the word kholop appeared in quite disparate sixteenth- and seventeenth-century sources: law collections, judicial cases, private transactions, contracts, memoranda, estate accounts, registrations with notaries, etc. Such documents never speak of kholopstvo in general, but qualify the word with adjectives: starinnoe (hereditary), polnoe (full), dokladnoe (registered), dolgovoe (obligated, indebted), zhiloe (limited to a period of time), dobrovol'noe (voluntary), kabal'noe (limited service contract). The latter was by far the most widespread term, found in 80 to 92 percent of the known contracts of kholopstvo, depending on the period. ${ }^{32}$ The multiplicity of qualifiers is significant, for it indicates a set of distinct kinds of contracts rather than a single formal personal status. Elite kholopy (mostly placed in the category of dokladnoe kholopstvo) served in the central government/palace administration and in the provincial administration until the mid-sixteenth century, in the cavalry until approximately the third decade of the seventeenth century, and as estate managers until the time of Peter the Great. ${ }^{33}$ The institution seems to have arisen around the end of the fifteenth century, and the last extant registered slavery document is dated before the end of the sixteenth century. Some of the major factors in this decline were the evolution of the central government from a royal household to an administration run by lay bureaucrats. Next was the radical decline of the large patrimonial estates (votchiny), which had needed stewards to manage them, in favor of an increase in smaller service estates (pomest'ia) that were increasingly managed by members of the middle service class.

Let us now examine the most widespread of these classifications, the kabal'noe kholopstvo, which appears in legislation, disputes, contracts between private individuals, wills, and estate inventories. ${ }^{34}$ All these documents mention the length of service and the possibility of transforming a six-month or one-year contract into a contract of unlimited service, ${ }^{35}$ although the latter practice was prohibited in the early seventeenth century. ${ }^{36}$ Before that, the code of 1550 already emphasized that the kabal'nye were not dolgovye (indebted). In subsequent years (1586 and 1597), new provisions confirmed that the kabal'nye could remain obligated only for the duration of the creditor's life, and that the creditor could not transfer the obligations to anyone, either in the form of a sale or inheritance. These same rules forbade the kholop to repay his debt. ${ }^{37}$ The latter provision could be interpreted as the desire to maintain the kholop in a state close to slavery, but it is equally legitimate to interpret it as a provision aimed to exclude that form of dependence. The link with the previous provisions would seem to confirm the latter interpretation. This conclusion is bolstered by all the contracts that have been found, 
which indicate the length of commitment, usually limited to one year. ${ }^{38}$ The evolution in the rules concerning the kabal'nye kholopy between 1586 and 1597 was inspired by the previous evolution of rules on military captives, notably the law of 21 August 1556, which prescribed that a military captive was to be enslaved no longer than the period of his captor's life and could not be passed on as a slave to the captor's children. ${ }^{39}$ From this standpoint, the change in the nature of limited service contract kholopstvo was instituted to safeguard the interest of the middle service class, whose members were at a disadvantage in competing with other members of the upper service class for kholopy. ${ }^{40}$

What remains to examine is the most extreme forms of kholopstvo. The "full" (pol'noe) variety was already developed in the Russkaia Pravda during the twelfth century and had three main sources: First, the kholop himself or herself might ask to be included in this category, as a form of repayment of a debt to the authorities. Second, if a female kholop married a free man without the authorization of the person entitled to her service, her husband became a pol'nyi (full) kholop. The third source was a domestic service contract established for an unlimited length of time, however such contracts have been found only between 1430 and 1554, with none appearing after that date. The most widely accepted hypothesis is that this form of dependence tended to be transformed into other forms of kholopstvo of a temporary nature.

The hereditary variety (starinnoe kholopstvo) seems to come closest to slavery in the strict sense and expresses the condition of those whose parents were kholopy. Such kholopy could be transferred in wills or given as a dowry or gift. In the contracts of 1430-1598 examined by Hellie, there were 5,575 kholopy, 483 of whom were hereditary. The kabal'nye knigi (kholopy registration books) at the end of the seventeenth century mention 418 hereditary kholopy out of a total of 2,168 registered at the time. The available sources do not allow us to say whether this higher percentage testifies to the poor economic situation of the time or to a long-term trend, because this type of commitment was prohibited by the decrees of 1586 and 1593.

To be sure, Iakovlev and, more recently, Paneiakh have found disputes and contracts concerning starinnye kholopy in the middle of the seventeenth century, decades after this type of contract was officially prohibited. ${ }^{41}$ In other words, despite the official prohibition, several lords continued to impose forms of contractual servitude of a hereditary type. The authorities devoted much attention to what amounted to illegal slavery and attempted to penalize transgressors. By banning this kind of servitude, the government sought to limit the power of nobles over peasants and thereby strengthen state authority over the owners of large estates. 
Furthermore, the kholopy were exempt from taxation, which reduced the revenue of the state. This was a measure intended to strengthen small landowners and encourage their alliance with the state. Among other things, the specialization of warfare in the early seventeenth century reduced the importance of cavalry while increasing the importance of an infantry wielding firearms. As a result, bureaucratic and military service continued to be meritocratic, but those possessing or developing merit were from outside the traditional service class. ${ }^{42}$ The evolution of kinds of kholopy and the people entitled to own kholopy enter these broader dynamics. In particular, measures to get rid of hereditary servitude had important consequences. Rather than exclude part of the population from all legal rights, as in the case of slavery, the solution consisted in assigning highly differentiated rights to the various strata of the population and dividing them into legally distinct groups. The peasants saw their rights severely restricted, while city dwellers were prohibited from subjecting themselves, even voluntarily, to any form of kholopstvo. Numerous provisions defined who was entitled to sign kholopstvo contracts as creditors or debtors. Thus, in 1641, all tiaglye liudi (people subject to tiaglo, i.e., the unit of taxation), including peasants and artisans, as well as other taxpayers, priests, artillerymen, and monastery servants, were excluded from the category of creditors entitled to demand labor service. ${ }^{43}$ Conversely, starting in 1590 , city dwellers subject to taxation (posad) were prohibited from offering these forms of labor service. In 1628, this prohibition was extended to include musketeers, soldiers, and all the intermediate ranks of the civil service and the military. The interpretation of these norms posed problems, because the categories were rather general. In the case of professions such as barbers, seamstresses, trappers, and small craftsmen, the question arose whether they could legitimately enter into kholopstvo contracts. The many petitions sent to the kholop chancellery concerning such individuals demonstrate their involvement in these contracts, their desire to be able to continue being taken on as kholopy, and their use of the law to challenge the claims of their counterparts. ${ }^{44}$

From this point of view, the 119 articles of chapter 20 of the Ulozhenie of 1649, which were devoted to kholopy, in large part reproduced the provisions of earlier legislation. The text specified the amount of work required to repay a debt or to fulfill an obligation in general for those who failed to meet their legal obligations (debts, penalties, fines, theft, etc.). Once the work was completed, the creditor brought the debtor back before an official, who released the debtor from all obligations. Section 20 of the Ulozhenie also mentions other conditions for being released from a state of kholopstvo. Various articles speak of both debts and krepost', with the latter viewed as justifying the debt. 
The core provisions of section 20 depart from the rules found in many slaveholding systems (including those in ancient Roman and Western colonial codes), although they do not differ much from those of slavery systems in Islamic and Catholic areas. Kholopy were free to marry, and such an act was inviolable. The wife of a kholop was obliged to remain in residence until her husband's debt was repaid, but upon her husband's death, the kholop's wife's dowry passed to her family and not to the landowner-creditor. ${ }^{45}$ The kholop could be called as a witness in a trial, which means that legal personality was acknowledged. Diverging most from systems of slavery elsewhere, a master of kholopy had no obligation to feed or care for elderly kholopy, whereas this obligation formed part of a master's commitment throughout the length of the contract itself. ${ }^{46}$

The available contracts show that about 20 percent of the kholopy were children between five and fourteen years of age whose parents placed them under one-year service contracts, which were often renewable, although some contracts were for rather long periods of time. Such contracts were signed by the most disadvantaged among the city population, and their numbers rose at the turn of the seventeenth century, a time of serious economic crisis. In a way, placing children in service ensured survival. From this point of view, the kholopstvo contract for children sprang from the same motives as several contracts of this type that were widespread during the same period in France and England (servants in husbandry), albeit with different legal terms and institutional conditions. ${ }^{47}$ The other kholopstvo contracts referred to adults working as servants. Loans were sometimes the formal reason for these contracts, but the terms of the loans often suggest that these were really servants' wages.

Taking these facts into account, we can conclude that especially following the decline of its hereditary forms, most of the aspects of kholopstvo resemble other types of indebtedness and limitation on mobility, such as forms of contractual servitude widely found in the same period among Hindu populations in India and in parts of China. Temporary servitude fell within the scope of contracts that were considered free and voluntary from a legal standpoint. Freedom of commitment did not exclude the renewal of contracts for up to several decades or even throughout the lifetime of the indebted person. ${ }^{48}$ However, the Russian situation differed from the one prevalent in the Islamic world, where sharia law forbade all forms of bondage for debt, crimes, and indigence, even if they occurred in practice under customary or sultan law. ${ }^{49}$

In virtually all the known Russian contracts, and increasingly so over time, the status of kholopy could not be transferred to descendants; this is essentially what distinguished this system from the slavery of antiquity and the Americas. In other words, by their very existence, forms 
of voluntary bondage testify to the variety of labor commitments and to continuity rather than opposition between these forms, ranging from statutory and hereditary slavery to free labor. Fugitives from the ranks of apprentices, domestics, and the indentured were caught by the state's police forces and subjected to criminal proceedings. Such penal sanctions also applied to the Russian kholopy.

Two main tendencies can be identified in the disputes over kholopy. They either involved several claimants to title or were disputes between these claimants and kholopy. In the first case, the question arose when someone claimed to have established a kholopstvo contract in good faith and the other party had previously signed one with another master. Such an individual was legally a fugitive. In the early sixteenth century, the Russkaia Pravda (article 118) stated that the first claimant to rights could recover the fugitive but had to compensate a buyer who had acted in good faith. However, the Sudebnik of 1550 adopted the principle of caveat emptor: the buyer of a title over a kholop was no entitled to be compensated, especially if he had been negligent. ${ }^{50}$ Finally, the Ulozhenie of 1649 returned to the previous principle. In every case, written documents were required to prove the validity of a plaintiff's claims.

There were also disputes between those who claimed rights over people and those in a situation of obligation who objected to the original obligation or to the terms of its cancellation. Such conflicts were so numerous that a kholopii prikaz (chancellery) was set up in 1571 to resolve issues of this kind. ${ }^{51}$ Some of the most frequent disputes concerned types of kholopstvo. Despite the prohibition against hereditary kholopstvo toward the end of the seventeenth century, the practice did not come to an end. Many cases were brought before the court at this time by kholopy themselves, often by the children of kholopy, or by new masters claiming their rights. ${ }^{52}$ The existence of these disputes confirms that it was possible for the kholopy to win a case, although the chances were slim compared with those of claimants to title. At the same time, this use of rights was possible because it intersected with the interests of other lords, other claimants over kholopy, or of the state itself, for the reasons mentioned above. It also explains why the few suits won by kholopy concerned the kind of kholopstvo and the kholop's obligations and rights toward one lord rather than another. Brutality against khol$o p y$ was actually punishable by law, but such laws were rarely enforced. The solution to this problem, rather, was found in the strong, disloyal competition among estate owners - the kholop could easily find another master; flight was easy; and recovery was extremely difficult and costly. Masters were therefore obliged to treat their kholop with relative decency or they would run away. ${ }^{53}$ 
Overall, by the time Peter the Great abolished the kholopstvo status in 1725 , the status applied to 10 percent of the population. ${ }^{54}$ Of the 2,500 contracts and documents that have been recovered, 92 percent originate from the Novgorod region, and 80 percent of the contracts were signed between 1581 and 1603. According to Hellie's calculations, 23 percent of the cases involved single men, and 60 percent, couples without children. The rest were couples with a minor child ( 1.6 percent), widowers ( 4 percent), widows (3.7 percent), married women ( 2.5 percent), or unmarried women ( 4.2 percent), while the status of the others was unknown. In the majority of cases, the kholopy were between ten and thirty-four years of age, but about 10 percent were between the ages of ten and fourteen, and another 10 percent between the ages of five and nine. Finally, throughout the period under study, from the sixteenth to the late seventeenth centuries, men made up at least two-thirds of the kholopy and often virtually all of them. ${ }^{55}$ Nearly all the kholopy were domestic servants and were rarely assigned to farmwork.

The link between kbolopy and debt bondage is clear when one relates the number of new contracts concerning kbolopy-mostly kabal'nye-and the dynamics of harvest between the 1580s and 1610. In the province of Novgorod, the number of kholopy rose by a factor of 8 tol 0 after bad harvests. ${ }^{56}$

Yet the kholopy were seldom acquired for farmwork, at least in Muscovy and European Russia. One possible reason that slaves and kholopy were infrequently found in Russian agriculture could be that masses of serfs already performed such functions. Kholopy and serfs therefore appear to have been complementary, and this may have constituted one of the dominant features of Russian history ${ }^{57}$ Kholopy initially were domestic, elite, and/or urban bonded people in a still-unstable, although expanding, state; later, their dismissal was linked to the solidification of state power with its fiscal and military needs and the rise of clear legal differentiations between hereditary and service nobles, peasants, artisans, urban groups, etc. The merging of kholopy with peasants was linked to state fiscal and military needs-kholopy, and delovye liudy (domestic servants) could enlist in the army starting in the early eighteenth century. Kholopy were initially exempted from soul tax, but their transition into existing legal-social groups (sostoianiia) corrected this situation. In other words, the long history of kholopstvo in Russia reflects the progressive formation of state power and the evolution in the relationship between various social groups and labor. In 1720, Peter replaced the household tax with the soul tax; this reform made it unacceptable to the public that kholopy, who were 10 percent of the population, were not submitted to the tax. 
The kholopy's conversion into "peasants," or lower urban groups, in 1725, solved this problem.

In the military realm, since the fourteenth century at least, kholopy (and fugitive kholopy) serving in the army were relieved of their "debt" and became free. This situation changed during the second half of the seventeenth century, when the authors of the Ulozhenie of 1649 quickly realized that freedmen were not likely to make good cavalrymen, and thus they allowed members of the middle service class who had been kholopy to return to their original status if they found military service not to their liking. ${ }^{58}$ In 1700 , faced with the Northern War, Peter the Great ordered that manumitted limited-service kholopy be enlisted in the infantry. But by 1703 the order was repealed, as the nature of warfare had changed during the second half of the seventeenth century, and the old middle service class cavalry had been largely phased out. This was a crucial step toward the abolition of kholopstvo. To a certain extent, therefore, the transformation of kholopostvo in connection with domestic and internal affairs cannot be isolated from the evolution of Russia on the international chessboard. War captives and the slave trade are part of this wider dynamic. In the following pages, we will study warfare and the slave trade in Eurasia in detail.

\section{War Captives at the Crossroads of Empires}

\section{Central Asian Slaves for the Mediterranean from the Thirteenth through the Fifteenth Century}

The importance of captives and slaves on the expanding Russian territory reflected changing power constellations in Central Asia, the southern Balkans, the Crimea, and the Mediterranean. The history of war captives in Russia and Asia is linked to the main trade routes and changing geopolitical situations over the centuries. The first phase, during the thirteenth and fourteenth centuries, was mostly connected to the Silk Road; the second, from the fourteenth into the sixteenth century, followed a Russian-Iranian-Indian path; and the third, from the sixteenth into the eighteenth century, was linked to the expansion of Russia and its integration of Mongol khanates. Each of these waves had commercial and geopolitical dimensions. Adding the captive-ransoming and slave markets to this picture sheds new light on the entire process.

The origin of the words esclaves and sclavus, which were used in medieval and early- modern Italy, expressed less the linguistic and legal heritage of ancient Rome than it did a link with the market for bound people 
from the Slavic areas. ${ }^{59}$ The slave trade had an economic boost in traffic from Central Asia to the Black Sea ${ }^{60}$ and from the growing presence of Venetians and Genoese in this area. ${ }^{61}$ In both Venice and Genoa, traders sold Circassian and Abkhazian slaves, who had previously been bought mostly in Caspian and Black Sea ports. We have evidence from as early as 1246 that the Mongols sold Greeks, Bulgarians, Ruthenians, and Rumanians to merchants from Genoa, Pisa, and Venice, who in turn sold them to the Saracens. The Italians had purchased these slaves in the northern Black Sea ports of Maurocastro, at the mouth of the Dniester and Caffa in the Crimea; in 1266, the Genoese received permission from the Mongol khan to establish a colony in Caffa. The Genoese merchants there bought Circassians, Tatars, Russians, Iranians, Poles, etc. The other center of the slave trade in the Black Sea region during the fourteenth century was the Crimean port of Tana, which the Venetians had colonized in 1333. In spite of the unstable favor of the Mongol ruler of Tana and the resulting breaks in trading activities, Tana still remained a place of high strategic value, allowing for better access to the Oriental markets and the Far East than the Genoese had in Caffa. The potentially high profits to be expected from trips to the eastern Black Sea area can be seen in the increased revenues from the galleys bound for Romania in the first half of the fourteenth century and after the 1370s. The main trading goods were furs, wine, grain, and slaves, with the slaves becoming increasingly important in the late fourteenth century, when Venice needed slaves for its colony on Crete. As a consequence of the growing Ottoman menace, the Venetian trade shifted to the western Black Sea (Maurocastro and the Danube estuary), Egypt, and the Middle East, in the first half of the fifteenth century. At Kilia, Tatar subjects were sold by their compatriots to Genoese, Venetians, and Greeks from Constantinople. ${ }^{62}$ Genoa, Venice, and Catalonia were also competitors in the slave trade. In 1263, the Byzantine Empire had reopened the trade between Egypt and the Black Sea, and Genoa became the first supplier of slaves for both the armies and harems of the Mamluk sultans. Male slaves were also sent to the alum mines of Genoa at Focea and, of course, to Genoa and Spain. Women were particularly welcomed for domestic services, while men were valued for ship work or sold to Spain. In early 1400, almost 10 percent of Genoa's population was unfree-that is, between 4,000 and 5,000 people. ${ }^{63}$ In Caffa, the revenue from the gabella capitum allows us to calculate the following numbers: in 1374 there were at least 3,285 slaves; in $1385-86$, about 1,500 ; in 1387-88, about 1,600 ; and in 1381-82, at least 3,800 . During the fifteenth century, the gabella was farmed out. For 1411 one can assume 2,900 sold slaves, and from the 1420s until 1477 there were 2,000 per year at most. The fall of Constantinople provoked 
a massive decline (to about 400 or 600 slaves per year). Thus during a single century the numbers fell by around 80 percent, a decline that was already apparent before 1453; both the gabella incomes of February and June follow this trend. ${ }^{64}$

War captives and people already enslaved in internal areas-the same type of people sold later in transatlantic slavery-were then sold to Genoa. But according to Genoese sources, "voluntary" enslavement was equally widespread, that is, Genoese enslavement of legally free people whom they seized in Caffa. However, neither Genoese nor Venetian traders organized expeditions with this specific aim in Central Asia, most likely because of the small scale and high transaction costs of the operations. ${ }^{65}$ It was simply not worth extending to Central Asia the credit and commercial arrangements already in place on the Black Sea, and this was all the more true for slaves, a minor market compared to that of luxury items. The caravan trade, much too wide ranging for European powers, was solidly based on the interaction between nonpastoral nomadic activities and caravan merchants. Increasingly stable communities in Central Asia offered a reliable environment. Islamization of the area further drove this process but did not immediately marginalize Venice and Genoa; at first they even benefited from the decline of the Byzantine Empire, not only in terms of commercial trade but also of the captives' market. ${ }^{66}$ At the same time, the rivalry between Venice and Genoa prevented either one of them from controlling the Black Sea trade. In 1462, after the fall of Constantinople, Genoese Caffa placed itself under the protection of Poland. From 1466 to 1474, intervention by the Genoese became particularly marked. Ultimately Muhammad the Conqueror captured Caffa in 1475 and took control of the trade of goods and slaves from Central Asia. In 1459 the Venetian senate lamented the scarcity of slaves, as most of the Slavic and Tatar slaves were now being sent to the Near and Middle East, in particular to Egypt and Turkey ${ }^{67}$ Genoa therefore turned to other sources, that is, to Islamic Spain and North Africa, where it acquired slaves to sell in Seville and the Canary Islands. It was at this point that Genoa tried to enter the slave market in the New World, but it was quickly overtaken by Spanish, Portuguese, and finally British vessels. ${ }^{68}$

At first glance, this outcome would seem to confirm the traditional historiographical view of a progressive shift from the Mediterranean to the Atlantic. ${ }^{69}$ According to this view, the decline of Venice and the Italian republic was linked to the rising power of Spain and the Western European powers (Portugal, the Netherlands, Britain, and France) that resulted from the exploration and colonization of the Americas. While not totally incorrect, this view is nonetheless prejudiced insofar as it 
ignores what was transpiring in Central Eurasia, Russia, and the Ottoman Empire at that time.

\section{The Indian Network from the Fourteenth to the Seventeenth Century}

Indeed, the traffic between Central Asia and Venice and Genoa intersected with the resurgence of the caravan trade; this development was linked to Mongol and Ming political stabilization, which was achieved from the fourteenth to the sixteenth centuries. ${ }^{70}$ By the early sixteenth century, the Uzbeks, Kazakhs, and Kyrgyz dominated the steppes. Muscovite expansion and increasing division among Mongol groups and heirs to the Golden Horde strongly contributed to reshaping the caravan trade in Central Asia from the fourteenth century on, while the traffic in slaves increased..$^{71}$ Caravan trade among China, Persia, Central Asia, the Ottoman Empire, and Russia accorded with the systematic traffic in slaves, as did similar trade among Russia, Central Asia, and India or the Ottoman Empire. The Indian-Central Asian caravan trade was, in large measure, a latter-day continuation of the enterprise that had led Indian Buddhists to move out along the same routes centuries earlier ${ }^{72}$ - Indian slaves had been exported from Central Asia since ancient times. Indian chroniclers mention slaves in the tens and even hundreds of thousands, ${ }^{73}$ while Central Asian sources suggest that slaves were put to work in masonry, construction engineering, agricultural production, and other forms of skilled and unskilled labor. Even if slaves were drawn from a number of regions-including the nomadic steppes, Iran, Afghanistan, the Caucasus, and Russia-judicial sources from the turn of the sixteenth and seventeenth centuries show that Indians accounted for at least 58 percent of all slaves. ${ }^{74}$

In the sixteenth century, Indian slaves, both Hindus and Muslims, were sold on the markets of Tashkent and Samarkand, along with other slaves from Lithuania, Russia, and the Caucasus.$^{75}$ Between the twelfth and seventeenth centuries there are indications of bonded people being part of the caravan trade from Central Asia to India and China and vice versa, i.e., from India to Central Asia. ${ }^{76}$ This trade went along with the general trade in luxury items and horses that took place along the same axes. ${ }^{77}$ The traffic had begun in ancient times but evolved dramatically during the medieval period, particularly in conjunction with the expansion of Islam in India during the early eleventh century and later, when the Indian merchant diasporas emerged in the sixteenth century. ${ }^{78}$ The Indian merchant diasporas, and in particular the Indian community in Astrakhan, strongly supported this traffic; Persian merchants also contributed to it. ${ }^{79}$ 
Samarkand was perhaps the quintessential caravan city- what would be the future political capital of Tamerlane (and the regional capital of earlier dynasties) was located close to where the east-west route intersected the north-south highway between India and Russia and was embedded in a fertile garden. ${ }^{80}$ Indian slaves reached Central Asia in different ways; some were secured in exchange for Central Asian goods, for horses in particular; some were war captives; while many others were captured during raids on trading caravans. ${ }^{81}$ In 1014, the sultan of Gazna brought 200,000 Indian slaves into his town. In Turan, in the early fourteenth century, sultans owned between 50,000 and 180,000 slaves each. Indian slaves worked in agriculture and were employed in other domestic activities in Bukhara in the late fourteenth and the early fifteenth centuries. ${ }^{82}$ Skilled slaves were particularly valuable, which is why rival political powers commonly enslaved and relocated artisans in the wake of successful invasions. Indian slaves were also sold in Bukhara and Astrakhan. At the same time, the Safavid Iranians were also sold as slaves, particularly after wars between the Uzbeks and Safavids. Enslavement of Iranians lasted until the mid-nineteenth century, when Russian and British sources speak of about 10,000 Iranian slaves in Khiva and over 100,000 slaves in the Khivan, Bukharan, and Turkmen territories. ${ }^{83}$ During the eighteenth century, most slaves at the markets of Bukhara, Khiva, and Kashgar came from Africa or from the mountains and desert fringes of Iran and Afghanistan. ${ }^{84}$ Many owners manumitted their slaves, mostly when they were over fifty years old, whereupon they spent the rest of their life in extremely poor conditions. There are also a number of cases of young slaves manumitted at the death of their master, which was in conformity with Islamic law. ${ }^{85}$

No less important, however, were the strong Islamic scholarly-scientific and cultural links that overlapped the trade routes, connecting Bukhara and Istanbul, the Ottoman capital, and extending across the Muslim Qazaq steppes all the way to Chawchak (i.e., Chuguchak, Tacheng) and beyond. India's Muslim and even Hindu merchants knew Farsi Persian, the main trading language, and some knew Turkic dialects, useful in Muscovy/Russia. Indian merchants developed some of the same techniques made famous in Renaissance Italy-palazzo-like trading houses (called havelis), kin networks, and credit-but they did not enjoy a corresponding Italian-style political organization of strong city-states to support them. ${ }^{86}$

In the eighteenth century, however, Indian slaves were relatively scarce in the markets of Bukhara, Samarkand, Khiva, and Kashgar. ${ }^{87}$ This was the case because, as usual, the traffic in slaves reflected the commercial trade and geopolitical equilibrium, and the strong links between Turkestan and South Asia appear to have suffered with the tsarist advance into the region. Tensions and rivalries between and within these political entities strongly 
contributed to the advance of Russia in the north and that of the European powers in the south. ${ }^{88}$ At the same time, Indian exports of slaves decreased, as the Mughal Empire reduced-but did not completely eliminate- the practice of enslavement in India. This process was concomitant with a progressive fragmentation of the Muslim world, which consisted of Central Asia and the Ottoman, Mughal, and Safavid Empires. By the seventeenth century, India had begun to manufacture enough textiles to clothe nearly the whole of Central Asia, as well as Iran, and thus there was no longer any need to exchange Central Asian horses and other goods for Indian slaves. ${ }^{89}$ According to some scholars, the most important development in the eighteenth century was the emergence of Afghanistan, under Durrani rule, as a powerful polity with particularly close links to northern India. ${ }^{90}$ To this one should add the progressive withdrawal of the Ottoman Empire from India and its general decentralization, which resulted in less slave traffic. In the seventeenth and eighteenth centuries, when Indian slaves almost disappeared in Central Asia, Indian goods entered the area; the Punjab in particular witnessed an unprecedented economic and demographic growth during this time, but this commerce later came to a halt with the rapid decay of the Safavid Empire and the Uzbek khanates, the Punjab's most important customers. ${ }^{91}$ India's communications with Central Asia were not only maintained, but even enhanced. Contrary to widely held beliefs, active bilateral trade between India and Central Asia continued between 1550 and 1750. In other words, recent historiographical trends do not see the decline of Indian slaves and certain Indian networks in Central Asia as indicative of a general decline of India, but as the result of its textiles being sold to new destinations and the emergence of new centers in Central Asia that were mostly dominated by Russians.

\section{Khanates, Nomads, and Russia from the Sixteenth to the Nineteenth Century}

The establishment of new trade boundaries between India and Central Asia paralleled the reconfiguration of the balance between Central Asia and Russia. This process is important to us because it links the historical dynamics of the Inner Asian slave trade to both the evolution of slavery in the Mediterranean and to the rise of serfdom in Russia. Without keeping in mind the long-standing tradition of trade in slaves and war captives, the peculiar link in Russia between territorial expansion, military concerns, fiscal problems, and serfdom cannot be understood. Ultimately, the geopolitical evolution of Russia and Inner Asia provides insights on the link between war, trade, and forced labor. The dissolution of the Golden Horde not only produced fully nomadic steppe societies such as 
the Nogays (a confederation of Turkic and Mongol tribes), but city-states such as the Crimean and Kazan khanates, as well. Turkic Kazakhs, Bashkirs, and Tatars competed with Mongol Kalmyks. Thus Central Asian political formations cannot be lumped together simply on the basis of an allegedly common nomadic nature. Russian expansion in Central Asia continued for over three hundred years, from the fifteenth through the eighteenth centuries. In the late fifteenth century, the alliance between the Crimea and Muscovy continued to be based on their mutual interests against their respective foes, the Great Horde and Poland. With the disbandment of the Horde in 1506, Crimea, the Muscovy, the Nogays, and Lithuania remained the major players in the region. Moscow actually began its real expansion eastward by conquering the steppe state of Kazan in the mid-sixteenth century. This marked the end of Muscovy's active participation in steppe politics for over seventy years. Instead, during this period, Muscovy turned westward and expanded across Siberia, while fighting against Polish and Lithuanian states. In pursuing this strategy, Moscow was first allied with Crimea against Poland, and then it weakened its relations with Crimea while strengthening ties with the Ottoman sultan. At the same time, the nomadic Nogays, unable to withstand the predations of the Kazakhs, abandoned their pastures east of the Yaik River and moved west, crossing the Volga into the pastures of the Astrakhan khan. The new khan of Kazan ravaged the provinces of Novgorod and Vladimir and moved toward Moscow; however, a confrontation was avoided insofar as Moscow and the Nogays had similar interests in the area. For Moscow, the Nogays were a critical force capable of checking the Crimean raids and aiding Moscow in the conquest of Kazan. ${ }^{92}$

In this same period-as a result of their action against the Genoese of the Crimea in 1475-the Ottomans made their presence more strongly felt among the Crimean Tatars and on the Pontic steppe in general, and by 1478 the Ottoman power established the right to appoint and dismiss the khans. Thus, with a single blow, Moldavian and Polish-Lithuanian access to Black Sea markets was brought to an end. By the beginning of the sixteenth century, the Black Sea had turned into an Ottoman lake.

Between 1555 and 1578, a number of events affected the Ottoman presence on the Black Sea: Muscovy took Astrakhan in 1556. Trade ties between Muscovy and Britain commenced about the same time, and soon the English Muscovy Company was sending its traders into Persia in quest of spices and silk, causing British woolens, hardware, and firearms to whet the appetite of the shahs. However, despite Istanbul's initial concerns over Moscow's conquest of Kazan and Astrakhan, it did not make containing Muscovite ambitions a priority, as it was engaged with the Habsburg power in the west and Persia in the east. By the early 
1560s, the sultan had adopted a more aggressive attitude and laid claim to Astrakhan, but war was avoided because of the shared geopolitical and commercial interests of Moscow and Istanbul.

Finally, the Ottomans established their suzerainty over the Crimean khanate between 1575 and 1578. The long war that followed, from 1579 to 1590 , resulted in the establishment of direct Ottoman rule over much of the Caucasus. This development was all the more important for Moscow in that it had already suffered two humiliating defeats by Poland-Lithuania and Sweden in the 1570s and early 1580s. From that time, the Nogays experienced increasing divisions and were ultimately debilitated by the arrival of the Kalmyks in the 1630s, although this did not prevent them from launching raids into Russia. Moscow thus undertook a new initiative: It began construction of fortification lines in the south. The construction went along with colonization of the region and explains the refusal of central and local authorities to return fugitive peasants from central Russian areas to their legitimate masters, which we discuss later on.

As in previous centuries, the captive-ransoming and slave trade followed the same paths as other commercial trade. Horse trade was particularly important for the local Muscovite economy and its military, like it had been for centuries in the north-south axes, but it acquired increasing commercial and political significance at this time. In the sixteenth and seventeenth centuries the horse trade was strictly controlled by the Russian authorities and was transacted in several Russian towns along the Volga. The horses were sold to the Russians by the Nogays and Kalmyks, who also sold them to the Crimean khanate. From 1551 to 1564 the Nogays bought an average of 7,400 horses a year for selling purposes. ${ }^{93}$ The Russian market also held enormous lure for the nomads; in the sixteenth century, the Nogays sought to obtain a wide variety of products (furs, woolens, armor, etc.) from Moscow, while in the seventeenth century the Kalmyks increasingly sold their horses to buy many of these items on the Russian markets.

The horse trade was important for the local Muscovite economy and its military, but it was the trade with the Muslim powers in Central Asia and with the rising Ottoman Empire that linked Muscovy to world markets. ${ }^{94}$ Russians sold the horses they acquired from steppe powers to the Crimeans and Ottomans. Merchants from the Central Asian khanatesCrimea, Persia, and the Ottoman Empire-brought merchandise to Moscow, while Russian merchants traveled to the Crimea; the Ottoman cities of Istanbul, Bursa, Azov, and Kaffa were the most important trade centers along a well-established trade route. 
Most important, exports of silk from Iran in the seventeenth century confirmed this new role of Russia. At that time raw silk produced in Iran was funneled into local Persian industry and was exported to India, the Ottoman Empire, and Europe. Historians have mostly studied exports from Iran to Aleppo and Venice, and the decline of these exports during the seventeenth and early eighteenth centuries (because of the British East India Company's expansion and its traffic between China, India, and Europe) has thus been cited as confirmation of the "rise of the West," namely Britain and its industry. ${ }^{95}$ But this conclusion does not take into account the considerable increase in the export of raw silk from Iran to Russia through Astrakhan, which varied from 20,000 to 100,000 kilograms per year at the turn of the eighteenth century. ${ }^{96}$

In other words, Moscow entered routes already in place, running east to west, north to southeast (India), and north to south (the Ottoman Empire). At the same time, these routes and this traffic associated slaves with other goods in accordance with long-established practices and routes, a situation quite similar to that in the Mediterranean area. As Mikhail Khodarkovsky has put it, if the steppe was akin to the sea and the Russian towns to ports, the nomads were the seamen. Many of the seamen were pirates living off the "ports" or looting the passing ship convoys. ${ }^{97}$ This indeed was the principal goal of the Russian government- to turn the pirates into merchants; and it was in this regard that the Russian authorities acted exactly as Ottoman and European powers had in the Mediterranean. ${ }^{98}$ Pirates were alternately encouraged and stopped, coopted and fought against, in the competitive rise of territorial states. Nomadic economies and powers were still inseparable from those of the neighboring sedentary societies. It is on these grounds that Perdue correctly stresses the necessity of overcoming later historiographic constructions of both the Russians and Chinese and of seeing the rise of stable territorial powers (China and Russia) as having helped secure the area, putting a halt to long-term nomadic raids and stemming powers that were detrimental to development and growth. While accepting this argument, one may still wonder whether (as per Perdue's argument) political and military instability in Eurasia during the sixteenth and seventeenth centuries - and not European expansion-reduced long-distance trade while benefitting the market for captives. ${ }^{99}$ Moscow's expansion in the south and changes in regional geopolitics certainly brought the trade with Crimea and the Ottoman Empire to a halt, at least for commercial items, while the traffic in captives and slaves increased because of this instability. At the same time, Muscovy competed with the Grand Duchy of Lithuania and Tver', and with the successor khanates. ${ }^{100}$ Kazan fell in 1552, but this did not 
mark the beginning of Russian conquest of the steppe; Muscovite rulers sought first to expand westward at the expense of the Polish-Lithuanian state. During this effort they occasionally allied with different khanates to exploit the latter's internal divisions. In 1501, during the campaign in Lithuania, Crimean Tatars seized 50,000 Lithuanian captives.

Russia once again moved eastward, in the second half of the sixteenth century, expanding into Siberia and certain Cossack areas, namely the territory of the Iaik Cossacks. ${ }^{101}$ The resulting prisoners of war and captives held for ransom fed a consistent market for slaves. The Russian word for captive, iasyr or esyr', was a direct transliteration of the Turkish and Arab equivalent as used in Central Asia and the Ottoman Empire. ${ }^{102}$

In the fourteenth century, some 2,000 Slavic slaves a year were sold by Crimean Tatars to Ottomans, with that figure rising in the fifteenth century. The Tatars either bought them at Central Asian markets or captured them themselves. ${ }^{103}$ Slave-raiding forays into Muscovy reached crisis proportions after 1475, when the Ottomans took over the Black Sea slave trade from the Genoese and the Crimeans began slave-raiding as a major industry, especially between 1514 and 1654. In 1529, half of the slaves in the Ottoman Crimea were identified as coming from Ukraine and Muscovy, and between 150,000 and 200,000 Russians were captured in the first half of the seventeenth century. ${ }^{104}$

Peace treaties often led to the release of slaves. In 1618, for example, the Nogays signed a treaty with Moscow and released 15,000 Russian captives. ${ }^{105}$ In 1661 the Kalmyks did the same with Russian captives they had previously acquired from the Tatars; in 1678, these same Kalmyks signed a treaty with Moscow and again returned Russian prisoners. ${ }^{106}$ There were specific criteria for redeeming Russian captives, thus, in 1661 the Kalmyk Mongols agreed to free Russians whom they had acquired through Tatars, and in 1678 they agreed to return Russians whom they had taken captive themselves. ${ }^{107}$ The Russians were redeeming slaves from Turkistan even as late as the mid-nineteenth century. ${ }^{108}$

The Ulozhenie of 1649 devoted a whole section (number 8) to the issue of ransoming Russian captives, ${ }^{109}$ and a ransom tax was introduced for this purpose in 1551 and remained in place until 1679. Ransom was stipulated in accordance with the captive's status. For example, the ransom for a high-ranking Russian boyar, B. V. Sheremetev, was estimated at 60,000 silver thaler. At the other extreme, peasants were ransomed at about 15 rubles per person. ${ }^{110}$ Those who were not ransomed became slaves and were assigned various duties. In the Crimea, some were employed in agriculture or used as interpreters and guides to lead war parties into Russian territory. Those sold on the slave markets of the Ottoman Empire or Central Asian khanates were employed as craftsmen, laborers, and 
domestics. ${ }^{111}$ Fugitives returning to Russia often gained the protection of local authorities, thereby provoking vehement protests from the Nogays leaders who laid claim to these fugitives as their property. ${ }^{112}$

Conversely, above all during the seventeenth century, Russians seized war prisoners and captives for ransom from both Muslim and Catholic areas. According to the Sudebnik of 1550, captives were intended to serve the elite as administrative assistants or servants. Their maximum term of service was supposed to be until the death of their master. They could also be redeemed by an agreement between the Russian state and their country of origin, and if they converted to Orthodox Christianity, they could also be emancipated, although this was not mandatory. Such a manumitting decree could also be issued by the state. This occurred in 1558 when the government ordered the freeing of any war slave who converted to Russian Orthodoxy, which allowed the former slave to enter the tsar's service.

If war captives were not redeemed or returned to their country of origin, they then entered the category of full or limited kholopstvo. Since the early seventeenth century, the state had tried to compile a register for military captives so that the central authorities could eventually return them to their home countries, in case of a diplomatic agreement. However, several sources note the problems the Moscow authorities encountered in ensuring compliance with these norms, and servitude for war captives persisted. After the conclusion of the Smolensk War, in October 1634, the government ordered the release of all Poles and Lithuanians who had been seized. However, the effect of this provision was quite limited, and in 1637-38 another decree was promulgated on foreign military captives, insisting that they had the right to choose whether to return home or stay in Muscovy.

After the Thirteen Years War (1654-67), Lithuanian and Polish captives were distributed to members of the upper and middle service classes but were not registered by the latter group, who tended, in practice, to treat them as genuine slaves. ${ }^{113}$ In 1655 , Poles, Lithuanians, and miscellaneous others, both adults and children, were openly sold in the streets of Moscow. ${ }^{114}$ As a result of this war, many people were sold in Russia, at times becoming kholopy. ${ }^{115}$ The Nogays, who had joined the Muscovite forces, purchased German and Polish prisoners in Moscow. ${ }^{116}$ Muslims were frequently captured and occasionally sold, in violation of Islamic law; the Ottoman and Islamic authorities therefore sent injunctions to Moscow in order to redeem them without compensation. ${ }^{117}$

Thus in 1690 the Russian government returned to its position of 1556, decreeing that military captives were to be manumitted by the Slavery Chancellery upon the death of their owners. As in previous times, 
this process went along with a renewal of trade routes. From the late sixteenth century on, delegations of traders had regularly traveled from Central Asia to Muscovy and-though less often-in the opposite direction. Bukharan interest in trade with Western Siberia also dates from the late sixteenth century. By the late seventeenth century, Muscovy was trading with China itself, often through the mediation of Bukharan traders who were familiar with all the major routes between Muscovy and China. Some of these routes followed traditional itineraries, leading down along the Volga to Central Asia and then on to Xinjiang and China. ${ }^{118}$

Fueled by this traffic, Siberian fairs emerged strongly during the seventeenth and eighteenth centuries; at Irbit, Russian traders, native Tartars, and Bashkir merchants exchanged horses and cattle from the southern Urals for Chinese goods (tea, cloth, silk). Persians, Bukharans, and Greeks also attended the fair, where servants and perhaps slaves were also sold. ${ }^{119}$ By the late eighteenth century, Orenburg had surpassed Astrakhan as the largest market on the steppe, a center for bartering horses and sheep and trading luxury items from the Far East. With the help of peddlers from Bukhara, Russians revived the caravan commerce. ${ }^{120}$ This was the case not only for the northern Eurasian caravan routes but also for the Indo-Iranian routes, which continued operating during the eighteenth century. ${ }^{121}$ The establishment of the Orenburg line did much to advance Russia's Asian economic frontier and increase Russo-Central Asian trade. At the same time, the Orenburg line was also a fortified frontier and a welcoming gateway for newly created trade opportunities. Diplomatic archives show that the Russian administration made efforts to motivate Asian merchants to shift their trade from the Iran-Caspian-Astrakhan line to overland routes leading through Central Asia to Orenburg. ${ }^{122}$ Over time, Asian merchants began to favor Orenburg, Omsk, and Ufa, which in turn caused a shift in the relative importance of different areas in Central Asia. In particular, in the middle of the eighteenth century, one-third of the total Persian silk production was directed to Moscow. ${ }^{123}$ Russians also expressed increasing interest in the Kokand khanate (in Uzbekistan) because of the role played by Kokandi merchants in the trade between Orenburg and Tien Shan, Yarkand, and other Xinjiang cities. The khanate became all the more important when cotton crops were developed in the Fergana Valley. Tashkent's role in international trade increased, along with the role of "colonial" Russian production of textile-substitute imports from Iran and India. At the same time, Russians used their influence in steppe politics to implement a rather successful strategy of divide and rule, in particular among the Kazakhs, which, in the short term, enhanced the market in captives. Russians could still be seized as captives or slaves in the early eighteenth century, though with less and 
less frequency. In 1717, the Kalmyks, this time temporarily allied with the Kuban Nogays, brought back 12,000 captives seized in the middle Volga provinces. In 1742, the Karakalpaks captured 1,000 Russian women and children in Siberia, and between 3,000 and 4,000 Russians are estimated to have been captives in their hands. ${ }^{124}$ This occurred at a moment in history when the Russian authorities were adopting an ambivalent attitude toward the Kazakhs, wishing as they did to dominate the area. ${ }^{125}$

However, by the end of the eighteenth century the only slaves and ransom captives in the Russian Empire were Tatars or Circassians. The highest-volume traffic in slave chattel and captives was with the Ottoman Empire. The Russian Empire interacted with Islamic regions where chattel slavery was common and regarded as the only permissible form of coerced labor under Islamic law. Muslim Tatars of the Crimea raided widely for Russian subjects as well as other eastern Slavs, Poles, and Lithuanians, and they exported most of their captives to the Ottomans. ${ }^{126}$ In 1529, half of all the slaves in the Ottoman Crimea were identified as coming from Ukraine and Muscovy; the other half was the Circassians. ${ }^{127}$ From the 1570s on, about 20,000 slaves were sold annually in the port of Caffa on the Black Sea. ${ }^{128}$ Until the early seventeenth century, Russians and above all Cossacks also sold captives to the Tatars or directly to the Ottomans. ${ }^{129}$ The Ottoman rules on slave trade distinguished between slaves who were brought from the Tatar and Circassian areas and those from Ottoman territories such as Azov and Taman. The tax on the latter was half of that on the former group. ${ }^{130}$

The Russian Empire also gradually incorporated areas in which local populations had long practiced various forms of servitude and slave trading. ${ }^{131}$ Many inhabitants of the Caucasus-especially Christian Georgians and Armenians, together with heterodox Muslim Circassians-were sent as slaves to the Ottoman Empire, whether overland or across the Black Sea. For the first three-quarters of the nineteenth century, the Ottomans imported between 16,000 and 18,000 such slaves every year. ${ }^{132}$ Some male slaves entered the servile administrative elite of the Ottoman Empire, while many women ended up in the harems of the rich and powerful. Circassian families at times sold their own children to intermediaries, who transported them to Ottoman territory. Under British pressure, the flow of slaves from the Caucasus was suspended in 1854, but it grew again after the end of the Crimean War. Moreover, the brutal Russian conquest of Circassia led to an influx of between half a million and a million refugees into the Ottoman domains between 1854 and 1865, of whom perhaps a tenth were of servile status. ${ }^{133}$ These massive arrivals increased the number of agricultural slaves, which had been relatively small until then (except in Egypt and Oriental Anatolia). ${ }^{134}$ 
In short, real slaves were present in Russia. As in other historical situations, they were typically taken in frontier raids, where boundaries were uncertain, or during military operations in the strictest sense. From a geopolitical standpoint, these forms of slavery were linked to conflicts within the Islamic world and between Russia and Central Asian powers, as well as to the conflicts that tore Europe apart in the seventeenth century. ${ }^{135}$ At the same time, this phenomenon did not mean that this large geographical area was backward, for flourishing trade and vital markets developed despite raids and military expeditions. The market for slaves and the markets for products were complementary, underscoring the fact that nomadic powers and territorial states were much more integrated with one another than usually stated in the historiography. One cannot simply associate captives and slaves with political instability or, for that matter, with stable powers, insofar as bondage could enhance or burden either configuration.

\section{Slavery in Central Eurasia: Its Estimation and Overall Interpretation}

Over the long run, the history of bondage in Russia and Eurasia provides useful insights into a number of historical questions: the link between bondage and war captives and between slavery and other forms of bondage; the dimension of bondage in Central Asian history; and the longterm links between Central Asia, Russia, the Turkish-Ottoman powers, India, and the Mediterranean area.

On a more abstract level, these topics lead to a discussion of several interlinked perspectives, i.e., the historical relations between nomadic powers, pirates, and national territorial states, that is, the monopoly of violence and the emergency of legal rights; and the relations between bondage, coerced labor, and economic development.

Our main answers to these questions may be summarized as follows: Not all Russian kholopy can be identified as chattel slaves, as all but a small minority had no hereditary status; they benefited from limited legal rights; and they could inherit and marry. The term kholopstvo expressed a form of bondage, quite common in other contexts in Asia and Africa and linked to two major phenomena: tensions and competition among the elites for the control of labor and mutual and hierarchical forms of dependence within the society. Kholopy had far fewer rights than their masters, but they still had legal rights. The master had some obligations as defined in the contracts of kholopstvo. If we term these relations "slavery," we miss the specificity of Russia in comparison with transatlantic or classical Roman slavery, and we compromise our understanding of 
the dynamics of Russian society. Any multiplication of different forms of bondage and relations of dependence reflects the way social links are established. Kholopstvo, like forms of bondage in other Asian and African societies, often was a form of inclusion, not of exclusion, in society (as chattel slavery is). This explains why, as in these other societies, the kholopstvo form of bondage applied to people of the same ethnicity and religion as their masters. From this standpoint, Russia does not constitute an exception in the worldwide history of slavery and bondage. Chattel slavery was mostly imposed on non-Russians. According to Hellie, in 1725, when Peter the Great abolished kholopstvo, kholopy constituted around 10 percent of the Russian population. However, their importance changed over time and from area to area. For example, the Moscow military census of 1638 listed 7,672 households containing 10,787 adult males, of whom approximately 1,735, or 16.1 percent, were kholopy. About 15.1 percent of the households reported having kholopy. ${ }^{136}$ In a broader census taken in 1678, in ninety-three central provinces, between 75,839 and 79,855 adult males were listed as zadvornye and delovye liudi (domestic servants) out of a total rural population (excluding those on properties that belonged to the royal court) of between 1,988,622 and 2,041,277 males, for proportions of between 3.7 and 4.0 percent. ${ }^{137}$

The evaluation of war captives and slaves in Inner Asia is more complicated than that of kholopy. Clearly, no definitive census of this trade is possible, since any research must depend upon suspect observations. Some of the observations are based upon custom reports, which represent the closest evidence we have to the working records and from which the best statistics are derived. However, unlike the accounts of merchants themselves, custom records only reflect the portion of a trade that is visible to government officials, and we are dealing here with regions where governments had only limited control over private-sector activities. Moreover, such records tell us only about the portion of trade that was legal. Even worse, external trade was a residual of local trades. Much of the slave trade was conducted by land, and in this case evidence is scanty. We may therefore only give some estimations, cautiously using sources that have already been exploited . On the basis of what we have seen in the previous pages, Genoa's imports of slaves from Caffa are estimated at around 250,000 , between the 1370s and the 1470s; Venice is estimated to have imported another 100,000 slaves from Tana and the Balkans. Some of them were sold in Italy, but most in Egypt. However, current research suggests we must be skeptical of these figures; Caffa customs data did not make any distinction between slaves and other passengers, and the first detailed analyses of the archives of daily registers and ships confirm the suspicion that the number of slaves per boat and those declared at the 
customs office were far fewer than usually stated (hundreds rather than thousands per year). ${ }^{138}$

Quantitative information on the trade route between India, Persia, and Inner Asia is even scantier than for Genoa and Venice. As a whole, we can estimate that there were about 200,000 Indian slaves in Bukhara, to which we may add other 200,000 Iranian slaves.

Ottoman and Russian archives provide good data on third network, connecting inner Asia, Russia, and Crimea. Russians seized by Tatars between the sixteenth and the first half of the seventeenth century are estimated at about 200,000. Many of them were sold to the Ottomans, but an undetermined portion was kept in Inner Asia and the Crimea. In particular, between the fourteenth and the sixteenth centuries, Crimean Tatars sold at least 2,000 slaves a year, or a total of 400,000 , to the Ottomans.

A compilation of estimates indicates that Crimean Tatars seized about 1,750,000 Ukrainians, Poles, and Russians in the following centuries, from 1468 to $1695 .{ }^{139}$ Crimean export statistics indicate that around 10,000 slaves a year, including Circassians, went to the Ottomans, suggesting a total of approximately $2,500,000$ from 1450 to $1700 .{ }^{140}$

From 1800 to 1909 , the Ottomans imported some 200,000 slaves from the Caucasus, mainly Circassians, with another 100,000 or so arriving with their Circassian masters in the 1850 s and $1860 s .{ }^{141}$ On average, between 1800 and 1875, the Ottomans imported 18,000 slaves per year from Caucasus and Crimea, for an overall figure of $1,350,000$ slaves.

The available, but still-incomplete, data provide the following numbers for the exports of slaves from Inner Asia and Russia: 4,000,000 to the Ottoman Empire; 400,000 through Venice's and Genoa's ports on the Black Sea; and 700,000 Persians and Indians traded in Central Asia. We lack data on internal trade, caravan trade, and the number of people who died during transportation. If we want start from a lower hypothesis, we may affirm that the Inner Asian slave trade that escaped customs statistics might reach half of this latter trade. We therefore come to about 6,000,000-6,500,000 people traded as slaves in Central Asia between the eleventh and the nineteenth century. This figure surely underestimates reality; however, even our minimal estimates permit some conclusions. First, the slave trade in Central Asia and Russia was the most important in the premodern era, and it does not rank far below the importance of later slave trade in other areas: eleven million people were traded along the trans-Sahara, Red Sea, and the Indian Ocean routes between the seventh and the twentieth century, as were eleven million slaves on the transatlantic route, from the fifteenth to the nineteenth century. ${ }^{142}$ 
From this standpoint, the history of slavery in Russia and Central Asia confirms what previous studies on Mediterranean slavery have already shown, that is, the importance of precolonial slavery, in particular outside the transatlantic route, and furthermore, the importance of these early routes in terms of the organization of labor, legal rules, and transnational powers. The slave trade in Russia and Central Asia was connected to the stabilization of territorial powers, the evolution of warfare, and the monopoly on violence. Indeed, the history of war captives and kholopy in Russia is linked to the incredible expansion of Muscovy and Russia and to the evolution of inner social relationships. Between the thirteenth and the sixteenth centuries, captives and slaves were commonly exchanged between the khanates, Safavid Persia, the Byzantine Empire, India, Genoa, and Venice. The slave trade accompanied general trade. Previous historiography estimated a decline of the caravan trade in Central Asia in connection with the development of the sea trade in the Mediterranean ${ }^{143}$ and then in connection with European powers' penetration into the Indian Ocean. ${ }^{144}$ A number of studies have recently reevaluated the efficiency of inland trade and confirmed that Central Eurasian trade did not decline after the seventeenth century but only shifted its objects, tools, leading groups, centers, and axes. The Mongols' power had guaranteed trade for centuries; their decline did not mean a decline of Central Asia, insofar as the Russians progressively took their place, while in the south, over all those centuries, the Safavids, Mughals, and the Ottoman Empire also ensured trade and economic growth. ${ }^{145}$ The horse trade, mentioned previously, was central: between 60,000 and 100,000 horses were imported each year from Inner Asia to Kabul-and from there sent to India. ${ }^{146}$ In the eighteenth century, this trade reached 400,000 to 800,000 horses per year. ${ }^{147}$

Textiles were the other major item traded in Inner Asia. In the mid-seventeenth century, India sent 25-30,000 camel-loads of cotton to Iran. This trade did not disappear with the arrival of the British, because as the imports of Indian textile to Britain drastically increased in the eighteenth century, Indian production increased to meet British and Central Asian demand. The silk trade between India, Iran, and Russia was also important; as mentioned earlier, Iran sold about half its raw-silk exports to Russia and the other half to Britain, at the turn of the eighteenth century. However these figures are scattered and incomplete; most new evidence comes from archeology and is hard to quantify. More generally, statistics from the Western trading companies and non-Western merchants in Inner Asia leave out data from Russia and the Ottoman Empire. Even if the Ottoman Empire's economic decline in the face of the Western 
expansion did not clearly materialize before the eighteenth century, in the seventeenth century real wages in Istanbul and other Ottoman towns were already lagging behind those of major Western European areas. ${ }^{148}$ Pointing out that Inner Asian trade did not collapse with the "rise of the West" is not meant to encourage a debate on the great divergence and relative rates of growth between Western Europe and Asia. Even if, for example, the importance of the textile and horse trade between India and Inner Asia is relevant to the debate about the impact of British expansion on India, and, eventually, on the Ottoman Empire, such topics lie beyond the scope of this book. Instead, I have stressed the persisting vitality of the Inner Asian trade in its connection with geopolitical dynamics and the slave trade in order to understand the main features of the expansion of the Muscovy and the rise of the Russian Empire. Starting from this, we are ready to face the main issues directly related to our investigation: the relationship between the slave trade and general trade in Inner Asia with the rise of serfdom in Russia, and the temporality and rhythm of the ensuing Russian growth as compared to that of the West. Indeed, Russian expansion in the steppes went along with the increasing importance of war captives (in institutional and economic terms, as we have shown) and, then, with the end of kholopy and the generalization of new forms of bondage, namely serfdom, in the Russian Empire.

\section{Notes}

I would like to acknowledge my debt to Peter Brown, who with great patience has helped me in revising both the form and the content of this chapter. I am also indebted to Christoph Witzenrath (Berlin) and Patrick O'Brien (LSE, London) for their comments.

1. Some references on this topic from a bibliography: Claude Meillassoux, Anthropologie de l'esclavage (Paris: PUF, 1986); Moses Finley, Ancient Slavery and Modern Ideology (New York: Viking Press, 1980); Suzanne Miers and Igor Kopytoff, eds., Slavery in Africa: Historical and Anthropological Perspectives (Madison: University of Wisconsin Press, 1977); Eric Williams, Capitalism and Slavery (Chapel Hill: University Of North Carolina Press, 1944); Bush, Serfdom and Slavery; Engerman, Terms of Labor; Orlando Patterson, Slavery and Social Death: A Comparative Study (Cambridge: Cambridge University Press, 1982); Paul Lovejoy, Transformations in Slavery: A History of Slavery in Africa (Cambridge: Cambridge University Press, 1983). On the translation of Islamic institutions with slavery: Ehud Toledano, Slavery and Abolition in the Ottoman Middle East (Seattle and London: University of Washington Press, 1998).

2. Martin Klein, ed., Breaking the Chains: Slavery, Bondage, and Emancipation in Modern Africa and Asia (Madison: University of Wisconsin Press, 1993).

3. For further discussion of this topic see Jack Goldstone, "The Rise of the West or Not? A Revision to Socio-economic History," Sociological Theory 18, 2 (2000): 175-94.

4. Hellie, Slavery in Russia in Russia.

5. Richard Hellie, "Recent Soviet Historiography on Medieval and Early Modern Russian Slavery," Russian Review 35, 1 (1976): 1-36; Herbert Leventer, "Comments on Richard 
Hellie's "Recent Soviet . . " Russian Review 36, 1 (1977): 64-67; Richard Hellie, "Reply," Russian Review 36, 1 (1977): 68-75.

6. Meillassoux, Anthropologie; Finley, Esclavage; Miers and Kopytoff, Slavery in Africa; Engerman, Terms of Labor.

7. Among the scholars who have defended this argument: on India: Gyan Prakash, Bonded Histories: Genealogies of Labor Servitude in Colonial India (Cambridge: Cambridge University Press, 1990); on Africa: Paul Lovejoy, The Ideology of Slavery in Africa (Beverly Hills: Sage, 1981); Paul Lovejoy, Toyin Fayola, Pawnship, Slavery, and Colonialism in Africa (Asmara: Africa World Press, 2003). On China: Anders Hansson, Chinese Outcast:Discrimination and Emancipation in Late Imperial China (Leiden: Brill, 1996); Harriet Zurndorfer, Change and Continuity in Chinese Local History (Leiden: Brill,1989); Chris M. Wilbur, Slavery in China During the Former Han Dynasty (Chicago: Field Museum of Natural History, 1943).

8. UNICEF, The State of the World's Children (Oxford: Oxford University. Press, 1991); ILO, International Labor Conference, Papers and Proceedings (Geneva, 2001); IPEC, Every Child Counts: New Global Estimates on Child Labor (Geneva: BIT, 2002); Suzanne Miers, "Contemporary Forms of Slavery," Canadian Journal of African Studies 34, 3 (2000): 714-47, special issue: On Slavery and Islam in African History: A Tribute to Martin Klein.

9. Fayola and Lovejoy, Pawnship.

10. Engerman, Terms of Labor; Northrup, Indentured Labor.

11. Peter Perdue, China Marches West: The Qing Conquest of Central Eurasia (Cambridge, MA: Belknap Press of Harvard University Press, 2005); Michael Khodarkovsky, Russia's Steppe Frontier: The Making of a Colonial Empire, 1500-1800 (Bloomington and Indianapolis: Indiana University Press, 2002); T. J. Barfield, The Nomadic Alternative (Englewood Cliffs, NJ: Prentice Hall, 1993); Nicolas di Cosmo, "Ancient Inner Asian Nomads: Their Economic Basis and Its Significance in Chinese History," Journal of Asian Studies 53 (1993): 1092-126; Nicolas di Cosmo, "State Formation and Periodization in Inner Asian History," Journal of World History 10 (1999): 1-40; David Christian, A History of Russia, Central Asia and Mongolia (Malden: Blackwell, 1998); Samuel Adrien Adshead, Central Asia in World History (New York: St. Martin's Press, 1993); André Gunder Frank, The Centrality of Central Asia (Amsterdam: VU University Press, 1992); Gary Seaman and Daniel Marks, eds., Rulers from the Steppe: State Formation on the Eurasian Periphery (Los Angeles: Ethnographics Press, 1991).

12. Charles Tilly, Coercion, Capital, and European States, AD 990-1992 (Cambridge: Blackwell 1990).

13. Douglass North, Structure and Change in Economic History (New York: Norton 1981); Eric Jones, Growth Recurring: Economic Change in World History (Ann Arbor: University of Michigan Press, 1988).

14. Jane Burbank, Fred Cooper, Empires in World History (Princeton: Princeton University Press 2010).

15. Rossiikii Gosudastvenny Arkhiv Drevnikh Aktov (henceforth RGADA), Kholopii prikaz, fond 210 (Razriadnyi prikaz), fond 396 (archiv oruzhennoi palaty, opis'l, chasty $1,2,4,5$, $7,11,24,26-33,35,36$, opis'2, ch. 2.

16. RGADA, fond 210 and 141 , opis'l, Dokumenty tsarskogo arkhiva i posol'skogo prikaza; fond 109 (snosheniia Rossii s Bukharoi), opis'1, 1643; fond 123 (Snosheniia Rossii s Krymom), opis'2 in particular; fond 127 (Snosheniia Rossii s Nogaiskimi Tatarami).

17. At the same time, as we will see, even in Perdue's case the problem is that the exclusive accent put on Russian and Chinese sources led scholars to underestimate the importance of the Safavid and Persian power in the area. This constitutes a major distortion of present-day historiography, due mostly to the over attention devoted to China and to the quasi-disappearance of specialists on ancient Safavids and Persian powers (and languages). 
18. Halil Inalcik, Sources and Studies on the Ottoman Black Sea: The Customs Register of Caffa, 1487-1990 (Cambridge, MA: Harvard University Press, 1996).

19. Archivio di stato di Genova (henceforth ASG), Massaria Caffae, 1374, fol. 1-354. See G. Bratianu, Actes des notaires genois de Pira et de Caffa de la fin du XIIIe siècle (1281-1290) (Bucharest: Académie Roumaine, Etudes et Recherches, ii, 1927); Michel Balard, Gênes et L'Outre-Mer, I: Les Actes de Caffa du notaire Lamberto di Sambuceto 1289-1290 (Paris and The Hague: Mouton, 1973). For later testimony, see Giorgio Balbi, "Atti rogati a Caffa da Nicolo' Beltrame (1343-44)," in Giorgio Balbi, Stefano Raiteri, Notai genovesi in Oltremare: Atti rogati a Caffa e a Licostomo (sec. XIV), (Genoa: Collana Storica di Fonti e Studi, 14, 1973),

20. Giorgio Pistarino, Notai genovesi in Oltremare. Atti rogati a Chilia da Antonio di Ponzo (1362-69) (Genoa: Collana Storica di Fonti e Studi, I 3, 1971).

21. Marhall Poe, "What did Russians Mean when They Called Themselves Slaves of the Tsar?" Slavic Review 57, 3 (1998): 585-608.

22. For example, Russko-dagenstanskie otnosheniia XVII-pervoi chetverti XVIII vv: Dokumenty $i$ materially [Russian-Daghestan relations during the seventeenth and the first quarter of the eighteenth century, documents and materials] (Makhachkala: Dagenstanskoe kn. Izd. 1958, vol. 79, p. 174), quoted in Khodarkovsky, Russia's Steppe Frontier, 37.

23. Aleksandr' I. Iakovlev, Kholopstvo i kholopy v moskovskom gosudarstve XVII v. [Kholopstvo and kholopy in the Russian state, seventeenth century] (Moscow: Nauka, 1943), 16-17.

24. This expression has usually been translated as "Any free person marrying a slave becomes a slave" (Hellie, Slavery in Russia, 93). This translation takes for granted that kholop meant slave and that $r a b$ was synonymous with kholop. But we have seen that the meaning of $r a b$ changed over time; also, if both rab and kholop meant slave, then why does the quoted expression contain no reference to a free person and the proposed interpretation assume such a reference (except if one argues that a kholop was a free person)? On the contrary, one overcomes these difficulties by accepting the argument that kholop signified a form of bondage, that rab expressed a particular bondage, and that, in the case of marriage between a kholop and a rab, they were jointly responsible for each other's obligation.

25. "Ole strashno ciudo I divno, brat'e, poidosha synove na ottsa, a ottsy na deti, brat nab rata, raby na gospodinu, a gospodin na raby," Lavrente'eskaia letopis' pod 1216, izd 1897, p. 419, quoted in Iakovlev, Kholopstvo, 29.

26. Mikhail F. Vladimirskii-Budanov, Obzor istorii russkogo prava [Summary of the history of Russian law], 6th ed. (Kiev: Izdanie knigoprodstva N. Ia. Oglobina, 1909); Entsiklopedicheskii slovar' Brokgauz-Efron [Encyclopaedia Brokgauz-Efron], vol. XVI (Saint Petersburg: Brokgauz, 1895), see entry for krest'ianie (peasant), 681. See also Slovar' russkogo iazika XVIII veka [Dictionary of the Russian language of the eighteenth century] (Saint Petersburg: Sorokin, 1998), vol. 10, entry for krepostnoi; Hellie, Slavery in Russia; Evgeniia I. Kolycheva, Kholopstvo i krepostinichestpo, konets XV-XVI vek [The kholopy and enserfment, end of the fifteenth century to sixteenth century] (Moscow: Nauka, 1971); Viktor M. Paneiakh, Kholopstvo v pervoi polovine XVII veke [Kholopstvo in the first half of the seventeenth century] (Leningrad: Nauka, 1984).

27. Iakovlev, Kholopy, 15.

28. Daniel Kaiser, trans. and ed., The Russkaia Pravda: The Expanded Redaction in the Laws of Russia. Series I: The Laws of Rus', Tenth to Fifteenth Centuries (Salt Lake City: Charles Schlacks, 1992), 31-32.

29. Kaiser, Russkaia Pravda, article 110.

30. Ibid., articles 117, 119, 120.

31. Nancy Kollmann, By Honor Bound: State and Society in Early Modern Russia (Ithaca and London: Cornell University Press, 1999).

32. Out of 2,499 documents containing the word kholop or kholopostvo, 2,116 refer to the kabal'noe variety (Hellie, Slavery in Russia, 33). Examples of contracts are in the manuscript 
section of the Saltykov-Shchedrin Library in Saint Petersburg, Obshchee sobranie gramot, $\mathrm{n}$. $1727,1937,1941,2017,2019,2348,2406,2635,2672,3026,3081,3392,3475,3486$.

33. Hellie, Slavery in Russia, 15.

34. Dokumenty $i$ dogorovnye gramoty velikikh $i$ udel'nykh kniazei XIV-XVI vv. [Documents and acts decreed by princes, fourteenth to sixteenth century], ed. L. V. Cherepnin and S. V. Bakhrushin (Moscow: Nauka, 1950), 409, document n. 98.

35. Paneiakh, Kholopstvo; Viktor Paneiakh, "Ulozhenie 1597 g. o kholopstve" [Ulozhenie of 1597 on kholopstvo], Istoricheskie Zapiski 77 (1955): 154-89.

36. In 1609, this was reduced from six to five months, and was further reduced to three months in 1649: Akty istoricheskie, sobrannye $i$ izdannye arkbeograficheskoin kommissieiu [Historical documents, collected and published by the Archeographical Commission], 5 vols. (Saint Petersburg, 1841-43), vol. 2, n. 85.

37. Paneiakh, "Ulozhenie 1597," 161.

38. Paneiakh, Kholopstvo..

39. Hellie, Slavery in Russia, 59.

40. Hellie, Enserfment and Military Change.

41. Paneiakh, Kabal'noe; Iakovlev, Kholopstvo.

42. Hellie, Slavery in Russia, 9-11.

43. Iakovlev, Kholopstvo, 316.

44. Opisanie dokumentov $i$ bumag, khraniashchikhsia v moskovskom arkhive ministerstva iustitsii [Inventory of documents and papers kept in the Moscow archives of the Ministry of Justice), vol. 15 (Saint Petersburg, 1908).

45. Arkadii Man'kov, Ulozhenie 1649. Kodeks feodal'nogo prava Rossii [The legal code of 1649: the code of feudal law in Russia] (Leningrad: Nauka, 1980), 113-14; Petr Ivanovich Ivanov, Alfavitnyi ukazatel' familii i lits, upominaemykh v boiarkikh knigach, khraniashchikhsia $v$ l-m otdelenii moskovskogo arkhiva ministerstva iustitsii [Alphabetical index of families and persons named in the boyari books, conserved in the first section of Moscow's Archives of the Ministry of Justice] (Moscow: Ministerstvo Iustitsii, 1853); Iakovlev, Kholopstvo: 496-513.

46. Hellie, Slavery in Russia, 211.

47. Anne Kussmaul, Servants in Husbandry (Cambridge: Cambridge University Press, 1981).

48. Gyan Prakash, "Terms of Servitude: The Colonial Discourse on Slavery and Bondage in India," in Breaking the Chains: Slavery, Bondage and Emancipation in Modern Africa and Asia, ed. Martin Klein (Madison: University of Wisconsin Press, 1986), 131-49; Zurndorfer, Change and Continuity, notably, chapter 5 .

49. Toledano, Slavery and Abolition.

50. Hellie, Slavery in Russia, 194-98.

51. Aleksei K. Leont'ev, Obrazovanie prikaznoi sistemy upravleniia v russkom gosudarstve. Iz istorii sozdaniia tsentralizovannogo gosudarstvennogo apparata $v$ kontse XV-pervoi polovine $X V I v$. [The formation of chancellery system in the Russian state: history of the formation of the centralized state, fifteenth and sixteenth centuries] (Moscow: Moskovskii Universitet, 1961), 179-92. Prikazy were settled since 1475; they were primarily branches of the army, but many of them had judicial function. Several dozen prikazy existed in the 1680s. Peter the Great revitalized, rationalized, and renamed the prikazy "colleges."

52. A number of law cases are discussed and fully transcribed in Hellie, Slavery in Russia, and in Iakovlev, Kholopstvo. Archives of the so-called kabal'nye and the kabal'nye knigi are in RGADA, Kholopii prikaz, fond 210 (Razriadnyi prikaz), fonds 396 (archiv oruzhenoi palaty, opis'1), chasty 1, 2, 4, 5, 7, 11, 24, 26-33, 35, 36, opis'2, ch. 2.

53. Hellie, Slavery in Russia, 506.

54. Kolycheva, Kholopstvo; Paneiakh, Kholopstvo.

55. Hellie, Slavery in Russia, 423-24.

56. Iakovlev, Kholopstvo, 35. 
57. Hellie, Enserfment and Military Change.

58. Hellie, Slavery in Russia, 84.

59. Jacques Heers, Esclaves et domestiques au Moyen Age dans le monde méditerranéen (Paris: Hachette, 1996), 67; Verlinden, "L'origine de sclavus," 97-128; Verlinden, "L'esclavage du sud-est," 18-29; Verlinden, L'esclavage; Epstein, Speaking of Slavery.

60. Herman Van der Wee, "Structural changes in Europeal Long-distance trade, and particularly in the re-export trade from south to the north, 1350-1750," in The Rise of Merchant Empires. Long Distance Trade in the Early Modern World, 1350-1750, ed. James Tracy (Cambridge: Cambridge University Press, 1990), 14-33.

61. Roberto Sabatino Lopez, The Commercial Revolution of the Middle Ages, 950-1350 (New York: Cambridge University Press, 1972), 92.

62. Dennis Deletant, "Genoese, Tatars, and Rumanians at the Mouth of the Danube in the Fourteenth Century," The Slavonic and East European Review 62, 4 (1984): 511-30.

63. Epstein, Speaking of Slavery; Domenico Gioffré, Il mercato degli schiavi a Genova nel secolo XV (Genoa : Bozzi, 1971); Robert Delort, "Quelques précisions sur le commerce des esclaves à Gênes vers la fin du XIVe siècle," Mélanges d'archéologie et d’histoire 78, 1 (1966): 215-50.

64. Michel Balard, "Esclavage en Crimée et sources fiscales génoises au XVe siècle," Byzantinische Forschungen 22 (1996): 9-17, reprinted in Henri Bresc, ed., Figures de l'esclave au Moyen-Age et dans le monde moderne. Actes de la table ronde organisée les 27 et 28 octobre 1992 par le Centre d'Histoire sociale et culturelle de l'Occident de l'Université de Paris-X Nanterre (Paris: Université Paris X 1996), 77-87.

65. Gioffré, Il mercato; Francesco Panero, Schiavi, servi e villani nell'Italia medievale (Turin: Paravia, 1999).

66. Gioffré, Il mercato.

67. Mikhail V. Kirilov, "Slave Trade in Early Modern Crimea from the Perspective of Christian, Muslim, and Jewish Sources," Journal of Early Modern History 11, 1 (2007): 1-32.

68. Geoffrey Vaughan Scammell, The World Encompassed: The First European Maritime Empires, c. 800-1650 (Berkeley: University of California Press, 1981).

69. Some classical references: Fernand Braudel, Civilisation matérielle, économie et capitalism, 3 vols. (Paris: Colin, 1977-79); Wallerstein, The Modern World-System.

70. Morris Rossabi, China and Inner Asia from 1368 to Present Day (London: Thames and Hudson, 1975); Niels Steensgaard, The Asian Trade Revolution of the Seventeenth Century: The East India Company and the Decline of the Caravan Trade (Chicago: University of Chicago Press, 1973).

71. There is debate whether the caravan trade declined or was simply reshaped. For the former interpretation see Rossabi, China and Inner Asia; Steensgaard, The Asian Trade Revolution; A. A. Askarov, ed. Istoriia Uzbekistana tom II: Pervaia polovina XIXe veka [History of Uzbekistan: First half of the nineteenth century] (Tashkent: Fan, 1993); Yuri Bregel, "Central Asia in the Twelfth-Thirteenth/ Eighteenth-Nineteenth centuries," Encyclopaedia Iranica 5, fasc. 2 (Costa Mesa: Mazda, 1992): 193-205. Against this interpretation, see Scott Levi, "India, Russia and the Eighteenth Century Transformation of the Central Asian Caravan Trade," Journal of Economic and Social History of the Orient 42, 4 (1999): 519-48.

72. André Wink, Al-Hind: the Making of the Indo-Islamic World, vol. 1, Early Medieval India and the Expansion of Islam, Seventh to Eleventh Centuries (Leiden: Brill 1991): 45-64.

73. Scott Levi, "Hindus Beyond the Hindu Kush: Indians in the Central Asian Slave Trade," Journal of the Royal Asiatic Society 12, 3 (2002): 277-88.

74. Levi, "Hindus Beyond the Hindu Kush."

75. Muzaffar Alam, "Trade, State Policy and Regional Change: Aspects of Mughal-Uzbek Commercial Relations, c. 1550-1750," Journal of Economic and Social History of the 
Orient, 37, 3 (1994): 202-27; Surendra Gopal, Indians in Russia in the Seventeenth and Eighteenth Centuries (Calcutta: Naya Prokash, 1988).

76. Adshead, Central Asia.

77. Jos Gommans, "Mughal India and Central Asia in the Eighteenth Century: An Introduction to a Wider Perspective," Itinerario 15,1 (1991): 51-70; Jos Gommans, "The Horse Trade in Eighteenth-century South Asia," Journal of Economic and Social History of the Orient 37, 3 (1994): 228-50; Jos Gommans, The Rise of the Indo-Afghan Empire, c. 17101780 (Leiden: Brill,1995). Islam Riazul, Indo-Persian Relations (Teheran: Iranian Culture Foundation, 1970); K. A. Antonova and Nikolai M. Goldberg, eds., Russko-indyskie otnosheniia $v$ XVIII veke: sbornik dokumentov [Russian-Indian relations in the eighteenth century: collected documents] (Moscow: Nauka, 1965).

78. Scott Levi, The Indian Diaspora in Central Asia and Its Trade, 1550-1900 (Leiden: Brill, 2002).

79. Levi, "India, Russia."

80. Janet Abu-Lughod, Before European Hegemony: The World System A.D. 1250-1350 (New York: Oxford University Press, 1989),178.

81. Alam, "Trade State Policy."

82. Oleg.D. Chekhovich, Bukbarkie dokumenty XIV veka [Documents from Bukhara, fourteenth century] (Tashkent: Nauka, 1965), 108-10.

83. Levi, The Indian Diaspora, 68.

84. Gommans, "Mughal India."

85. Audrey Burton, "Russian Slaves in Seventeenth-Century Bukhara," in Post-Soviet Central Asia, ed.Touraj Astabaki and John O'Kane (London: Taurus Academic Studies, 1998), 345-65. Brian Glyn Williams, The Crimean Tatars (Leiden: Brill 2001).

86. Levi, The Indian Diaspora, 121-22. Also André Gunder Frank, "ReOrient: From the Centrality of Central Asia to China's Middle Kingdom," in Rethinking Central Asia: Non-Eurocentric Studies in History, Social Structure, and Identity, ed. Korkut A. Ertürk (Reading, UK: Ithaca Press, 1999), 11-38.

87. Gommans, "Mughal India."

88. Marshall Hodgson, Rethinking World History (Cambridge: Cambridge University Press, 1993); Christopher Bayly, The Imperial Meridian (London: Longman, Pearson Education, 1989).

89. Kirti N. Chaudhuri, The Trading World of Asia and the English East India Company, 16601760 (Cambridge: Cambridge University Press, 1978).

90. Gommans, "Mughal India."

91. Alam, "Trade, State Policy"; Stephen Dale, Indian Merchants and Eurasian Trade, 16001750 (Cambridge: Cambridge University Press, 1994).

92. Khodarkovsky, Russia's Steppe Frontier: 102-3.

93. Prodolzhenie drevnei Rossiksoi vinliofiki, 11 vols. Saint Petersburg, Imper. Akad. Nauk, 1786-1801; reprint, C.H. van Schooneved, ed. Slavic Printings and Reprintings, 251 (The Hague-Paris: Mouton, 1970), vol. 8: 219-223.

94. Khodarkovsky, Russia's Steppe Frontier, 27.

95. Steensgaard, The Asian Trade Revolution.

96. Edmund Herzig, "The Volume of Iranian Raw Silk Exports in the Safavid Period," Iranian Studies 25, 1-2 (1992): 61-79. Nina G. Kukanova, Ocherki po istorii russko-iranskikh torgovykh otnoshenii v XVII-pervoi polovine XIXev veka [Studies on Russian-Iranian relations from the seventeenth to the first half of the nineteenth century] (Saransk: Mordovskoe knizhnoe izd-vo 1977).

97. Khodarkovsky, Russia's Steppe Frontier, 29.

98. Fernand Braudel, La Méditerranée et le monde méditerranéen à l'époque de Philippe II (Paris: Colin 1949); Janice E. Thomson, Mercenaries, Pirates, and Sovereign: State-building and 
Extraterritorial Violence in Early Modern Europe (Princeton: Princeton University Press, 1994); Wolfgang Kaiser, ed., Négociations et transferts. Les intermédiaires dans l'échange et le rachat des captifs en Méditerranée, XVIe-XVIIe siècles (Rome: Ecole française de Rome, 2008).

99. Perdue, China Marches West, 39.

100. Donald Ostrowski, Muscovy and the Mongols: Cross-cultural Influences on the Steppe Frontier, 1304-1589 (Cambridge: Cambridge University Press, 1998); John Fennell, Ivan the Great of Moscow (London: MacMillan, 1961); John Fennell, The Crisis of Medieval Russia, 1200-1304 (New York: Longman, 1983); John L. Fennell, "The Dynastic Crisis, 14971502," Slavonic and East European Studies 39, 92 (1960): 1-23.

101. Brian Davis, State, Power, and Community in Early Modern Russia: The Case of Kozlov, 1635-1649 (Basingstoke, NY: Palgrave, Macmillan, 2004).

102. Elena N. Shipova, Slovar' turkizmov v russkom iazyke [Dictionary of Turkish into Russian language] (Alma-Ata: Nauka, 1976), 442.

103. Alan Fisher, "Muscovy and the Black Sea Trade," Canadian-American Slavic Studies 6, 4 (1972): 582-93.

104. Aleksei A. Novosel'skii, Bor'ba Moskovskogo gosudarstva s tatarami v pervoi polovine 17 veka [The fight of the Muscovite state against the Tatars during the first half of the seventeenth century] (Moscow, Leningrad: Nauka, 1948).

105. Norman Davies, God's Playground: A History of Poland, 2 vols. (New York: Columbia University Press, 1982), 1:139-41; Khodarkovsky, Russia's Steppe Frontier, 21-22.

106. Materialy po istorii Uzbeskoi, Tadzhikskoi I [Materials for the history of Uzbekistan, Tajikistan, and Turkmenistan], part 1 (Leningrad: AN SSSR, 1932), 386-397, quoted in Hellie, Slavery in Russia, 25, note 43.

107. Khodarkovsky, Russia's Steppe Frontier.

108. William Gervase Clarence-Smith, Islam and the Abolition of Slavery (Oxford: Oxford University Press, 2006), 118-19.

109. Richard Hellie, ed., The Muscovite Law Code (Ulozhenie) of 1649, part. 1 (Irvine, CA: Charles Schlacks, 1988), 17-18.

110. Rossiiskaia Akademiia nauk. Arkhiv, fond 1714, op. 1 (A.A. Novosel'skii), delo 66, 1. 123; RGADA, fond 123, opis' 3, delo 13.

111. RGADA, fond 123, Krymskie dela 13, 1. 53; Materialy po istorii Uzbeksoi, Tadzhiskoi i Turkmenskoi SSR, vol. 1 (Leningrad, Moscow: Nauka, 1932): 386-7.

112. RGADA, fond 109, opis' 1, d. 1643.

113. Hellie, Slavery in Russia, 68-69.

114. Paul of Aleppo, The Travels of Macarius; Extracts From the Diary of the Travels of Macarius, Patriarch of Antioch, ed. Lady Laura Ridding (London: Oxford University Press, 1936), 28,76 .

115. Aleksandr' L. Khoroshkevich, Russkoe gosudarstvo v sisteme mezhdunarodnykh otnoshenii kontsa $X V$-nachala $X V I$ v. [The Russian state in the system of international relations toward the end of the fifteenth and beginning of the sixteenth century] (Moscow: Nauka, 1980), 30-32.

116. Khodarkovsky, Russia's Steppe Frontier, 24.

117. RGADA, fond 89, Turetskie dela, delo 3.

118. Christian, A History of Russia.

119. Ronald Drew, "The Siberian Fair: 1600-1750," The Slavonic and East European Review 39, 93 (1961): 423-39.

120. Morris Rossabi, China and Inner Asia from 1368 to the Present Day (London: Thames and Hudson, 1975).

121. Dale, Indian Merchants; Alam, "Trade, State."

122. Antonova, Goldberg, Russkoe-Indiiskie. 
123. Gommans, "Mughal India."

124. Kazakbsko-russkie otnosheniia v 16-18 vekakh, Sbornik dokumentov $i$ materialov [RussianKazakh relations during the sixteenth through eighteenth century: collected documents and materials] (Alma-Ata: Akademia nauk Kazakhskoi SSSR, 1961 and 1964), n. 88:209, n. 33:64, n. 76:181,184. Also: Mezhdunarodnye otnosheniia v Tsentral'noi Azii: 17-18vv. Dokumenty I materialy, [International relations in central Asia, seventeenth and eighteenth centuries], 2 vols. (Moscow: Nauka, 1989).

125. After the disbanding of what the Russians called the Golden Horde, Mongol power fractured into several khanates in Inner and Central Asia. The Small, Middle, and Great Hordes were each ruled by a khan; they called themselves Kazakhs and were descended from Mongol and Turkic clans. The clans spoke Turkic and were Sunni Muslims (Martha Brill-Olcott, The Kazakhs (Stanford: Hoover Institutions Press, 1987).

126. Clarence-Smith, Islam, 13.

127. Alan Fisher, "The Ottoman Crimea in the Sixteenth Century," Harvard Ukrainian Studies 2 (1981): 141-42.

128. Halil Inalcik, "Servile Labor in Ottoman Empire," in Abraham Ascher, Tibor Halasi-Kun, and Bela Kiraly, eds., The Mutual Effects of the Islamic and Judeo-Christian Worlds: The East European Patterns (New York: Brooklyn College Press, 1979), 39-40; Yvonne Seng, "Fugitives and Factotums: Slaves in Early Sixteenth-century Istanbul," Journal of the Economic and Social History of the Orient 39, 2 (1996): 136-69.

129. Fisher, "Muscovy and the Black Sea."

130. Halil Inalcik, "The Custom Register of Caffa, 1487-1490," in Sources and Studies on the Ottoman Black Sea, ed. Victor Ostapchuk (Cambridge, Mass: Harvard University Press, 1996), 1:93, 145-46.

131. Sbornik Imperatorskogo Russkogo Istoricheskogo Obshchestvo (Collected works of the Imperial Russian historical society), vol. 41 (Saint Petersburg, 1884): 42-43, 52-53, 104-7, 115-121, 146-157.

132. Toledano, Slavery and Abolition: 8.

133. Thomas Barrett, "Lines of Uncertainty: the Frontier of the North Caucasus," Slavic Review, 54, 3 (1995): 578-601; Clarence-Smith, Islam: 13-14.

134. Toledano, Slavery and Abolition: 81.

135. David Brion Davis, Slavery and Human Progress (New York: Oxford University Press, 1984); Robert Crummey, The Formation of Muscovy, 1304-1614 (London: Longman, 1987).

136. Rospisnoi spisok goroda Moskry 1638 goda [Lists of the town of Moscow in 1638] (Moscow: Tipografiia Moskovskogo Universiteta, 1911).

137. Ia. E. Vodarskii, Naselenie Rossii v kontse XVII-nachale XVIII veka [The population of Russia during the seventeenth to the early eighteenth century] (Moscow: Nauka, 1977).

138. Annika Stello, "La traite d'esclaves en Mer Noire au début du XVe siècle," paper at the international conference on: Esclavages en Méditerranée et en Europe Centrale. Espaces de traite et dynamiques économiques (Moyen Âge et temps modernes), Casa de Velázquez, Madrid, 26-27 March 2009.

139. Fisher, "Muscovy and the Black Sea."

140. Halil Inalcik, An Economic and Social History of the Ottoman Empire, vol. 1, 1300-1600 (Cambridge: Cambridge University Press, 1997): 285.

141. Ehud Toledano, The Ottoman Slave Trade and its Suppression (Princeton: Princeton University Press, 1982), 82, 90.

142. On Africa and the Indian Ocean, see Lovejoy, Transformations in Slavery; on the volume of transatlantic slaves, see David Eltis, Stephen Behrendt, David Richardson, Herbert Klein, The Trans-Atlantic Slave Trade: A Database on CD-Rom (Cambridge: Cambridge University Press, 2000). 
143. Steensgaard, The Asian Trade Revolution.

144. Kirti N. Chaudhuri, Asia Before Europe: Economy and Civilization of the Indian Ocean from the Rise of Islam to 1750 (Cambridge: Cambridge University Press, 1990).

145. Gunder Frank, "Re-Orient"; Levi, India and Central Asia; Dale, Indian Merchants.

146. Levi, "India, Russia," 528.

147. Gommans, The Rise.

148. Sevket Pamuk, "The Black Death and the Origin of the Great Divergence across Europe, 1300-1600," European Review of Economic History II (2007): 289-317. 
CHAPTER 4

\section{The Institutions of Serfdom}

Already in 1921, Marc Bloch warned against the use of the word serf and the expression "serf of the glebe." He showed in particular that the notion was absent in the Middle Ages and, on the contrary, became widely used after l'Esprit des lois by Montesquieu, in 1748. From this point of view, the expression "serf of the glebe" was used to identify a largely stylized feudal system and place it in opposition to an equally stylized liberal economic system. ${ }^{1}$ Ever since, medieval studies has adopted this conclusion widely for France and Britain, ${ }^{2}$ and more recently, a similar reassessment has been made for the German second serfdom (notably in criticizing Brenner's argument). ${ }^{3}$

Discussions of Russian serfdom have adopted a much more cautious attitude; they have mostly focused on serfdom's origin (the state ${ }^{4}$ and/ or the landowners ${ }^{5}$ ) and its profitability, ${ }^{6}$ rather than on the interplay between its legal rules and economic activity. The most remarkable contributions to this study are those of Confino, Hoch, Wirtschafter, Melton, and Moon, who have effectively revisited the simplistic definition and functioning of Russian serfdom, questioning the dynamics of serfdom and its rules. ${ }^{7}$ It has been suggested that serfdom was never officially introduced $^{8}$ in Russia and that it was more of a set of practices than a formal system. ${ }^{9}$ Starting from this point, some have argued that serfdom could have been profitable, if not throughout Russia, at least in many areas of the country. ${ }^{10}$ Historians are eager to extend research in the same direction by analyzing the rules that define the legal status of actors and assess their implementation.

This chapter is based upon numerous archival and published sources. I have made use of Russian archives, mostly archives of ancient Russia (RGADA) and local archives in Moscow (with local law courts' decisions). I further consulted the impressive collection of Russian laws, decrees, 
and jurisprudence, ${ }^{11}$ which provided me the opportunity to absorb the incredible number of rules adopted on our topic and their connection with rules concerning the nobility and the family, but also the main jurisprudential decisions adopted by high courts and the Russian senate.

\section{Property Rules and the Legal Status of Russian Peasantry}

Russian rules never spoke of "serfs" but rather aimed to identify people entitled to transmit "immovable" property. In fact, Russian and Western historiography considers krepostnoe pravo to be the Russian-language equivalent of the word serfdom, just as krepostnye liudy has been translated as serfs. These translations may be correct, however the expression krepostnoe pravo did not appear in Russian texts until the late 1830 s. $^{12}$ If we consider official Russian texts from the sixteenth to the middle of the nineteenth centuries, ${ }^{13}$ we find no use of the words krepostnoe pravo but only krepostnye liudy (people subject to a krepost', a deed), kret'iane (a word usually translated as peasant). ${ }^{14}$

The limitation of peasant mobility was not a goal in itself, such limitation did affect relationships between different groups of landowners and the state. ${ }^{15}$ Since the fifteenth century, a so-called obedience charter (poslushnaia gramota) was granted to peasants living on state lands, which had been awarded as service landholding (pomest'e) to members of the provincial cavalry to support them in service. Peasants were an appendage of the state, but they had to pay rent to servicemen, even though many peasants believed these lands belonged to them.

The Sudebnik (law reports) incorporated and widely applied the provisions that had originally been intended (in 1455-62) for monastery peasants only, which called for limiting their mobility. ${ }^{16}$ After 1565, Ivan IV changed the "obedience charter" and added a clause stipulating that peasants were obligated to obey the landholder. Cavalrymen took this as license to increase rent. But why were these rules adopted?

An old historiographical view linked the enserfment of the peasantry to the evolution of economic conditions. The economic crisis, famines, and population decline were said to have led landowners to demand the state make rules tying peasants to the nobles' estates. ${ }^{17}$ In this view, the rise in farm prices beginning in the sixteenth century and the subsequent increases in the early seventeenth century that occurred because of poor harvests and famines were supposed to encourage noble landowners to bind the peasantry in order to benefit from price rises. ${ }^{18}$

This argument is encountering increasing criticism. The relative decline in population during the middle of the seventeenth century has been overestimated, and, furthermore, it came after nearly a century of 
demographic growth. ${ }^{19}$ In general, there is no empirical confirmation of the argument that the indebtedness of the peasantry and low population led to serfdom. ${ }^{20}$

Some other scholars have linked these limitations to territorial expansion, the lack of manpower, as well as to tax and military burden. ${ }^{21}$ But in fact, most of the nobility was hostile to territorial expansion, which was viewed as a source of instability and blamed for reducing the available manpower. ${ }^{22}$ Indeed, measures for delimiting property were not only dictated by taxes and military requirements of the state, but they also reflected a redefinition of the relationships between social groups and the state, namely, the role of land property as a social and political marker. ${ }^{23}$ The rules were thus appropriated by the state and broadened to include the entire peasantry in relation to the Muscovite leaders' attempt to establish a land register. Throughout the sixteenth and seventeenth centuries, several rules were adopted that had the effect of limiting peasant mobility; however, these rules were actually designed to establish a cadastre to improve tax income and military conscription, while also aiming to settle disputes over estates to which there were various claimants, including the crown, the church, monasteries, and various categories of nobles. In other words, the Muscovite elites' claims to and conflicts over land were at the root of rules concerning the cadastre; peasant mobility was only a secondary cause. ${ }^{24}$

These rules meant that peasants could move from central Black Earth lands to state or court lands if they felt so inclined, and there is no doubt that many peasants moved freely about Russia and that the government took measures to ensure they had the right to do so. Until the first half of the seventeenth century, the restriction was assumed to be temporary; by the 1630s, landlords even came to enjoy the right to allow their peasants to move, as can be seen expressed in many documents (the otpusknaia gramota). ${ }^{25}$ Such documents were signed by landowners, for example, to let their peasants marry on another estate, move to towns, etc. In exchange for mobility, peasants had to pay a fee. Upon closer examination, serfdom resembled a form of racket much more than it resembled slavery.

The process was by no means simple, as is evidenced by the numerous legal disputes and petitions drawn up by noble families against other claimants to their properties, whether nobles, merchants, boyari, or others. ${ }^{26}$ The alliance between the state and the provincial and lesser nobility was supposed to offer a solution, with new rules on runaways being adopted in exchange for landowners' acceptance of a cadastre. However, this alliance proved to be ineffective, because different state administrations were unable to cooperate in achieving a cadastre, returning 
runaways, or punishing owners whose claims were illegitimate. To that must be added the lack of cooperation among landowners, who continued to retain peasants on the move-so-called runaways. Petitions multiplied between the 1620s and the 1640s, and the central state responded by lengthening the time to recover fugitives from five to nine to fifteen years ( decrees ofl637, 1641, 1645, 1648).

This is where the famous Ulozhenie intervention of 1649 comes in; according to many interpretations-Russian, Soviet, and Western alikeit marked the final adoption of the servile regime in Russia and thereby the central role of the state in the process. ${ }^{27}$ Yet if we read that document carefully, we find that it contains nothing concerning the organization of work on the estates. ${ }^{28}$ The document mentions peasants and the rural population, but not serfs. The thirty-four articles that make up its eleventh chapter define the rules governing runaways, which is to say peasants, not serfs.

The term peasants referred to individuals, with or without land, who were members of any rural community. The "runaways" described in the eleventh chapter of the Ulozhenie intervention of 1649 were said to have moved outside their own rural districts without the permission of the landowner or the local public authority, in order to settle in another rural district or to place themselves under the authority of cities, monasteries, and so on. The term referred to members of rural communities with obligations toward either private landowners or the state, or toward their rural community. ${ }^{29}$ The text did not refer in any way to a title of ownership of peasants but rather to attestations of land registration of noble estates. That explains why this text included no sanction against peasants who fled but strongly sanctioned lords who received the runaways. ${ }^{30}$ Exactly as they did before the Ulozhenie, peasants continued to sign "settlement contracts" 31 with landlords in which they defined the conditions and terms of their obligations.

To what extent did these rules contribute to solving the long-term questions of land ownership and social status in Russia and, in particular, to the unfair competition between hereditary nobles, with their practice of keeping runaways; the sharp conflicts between nobles in government service and hereditary nobles; as well as the conflict between nobles and merchants?

The available sources reveal clear attempts by the state to enforce rules, ${ }^{32}$ but as the records of litigation among landowners and between urban merchants and landowners plainly show, ${ }^{33}$ the legal definition of those who had the right to own and transfer populated estates was not clear. The great landlords became notorious for luring peasants away from smaller estates. ${ }^{34}$ This game became even more complicated when 
urban elites (with fiscal motives) and peripheral authorities (interested in increasing the local population) pushed to keep the runaways in place. Negotiations concerning this occurred on the legal, administrative, and political level. ${ }^{35}$

Annexation of new territories and the colonization of the steppe further weakened these already barely enforced rules. In 1635 a decree authorized commandants of local garrisons and southern governors to guarantee residence to fugitive peasants and not to return them to their legitimate owners. The following year, a new ordinance freed all those whose mobility had been restricted after 1613. Petitions by estate owners increased so much that in 1636, the central authorities decreed the obligation to return fugitive peasants to their legitimate owners. The Ulozhenie of 1649 sought to reinforce these rules. However, in the southern areas even more than in the heartland, the rules were barely enforced. ${ }^{36}$ In the eyes of some tsarist elites, geopolitical considerations overwhelmed the political and social defense of estate owners in the central areas of Russia. As a consequence, between 1678 and 1897, peasants' settlements in the central forest heartland fell from 69.9 to 41.22 percent of the total cultivated land, while those in the steppe areas increased from 28.78 to 41.22 percent. During this same period, settlement in Siberia rose from 1.32 to 7.54 percent. In the southern and eastern settlement areas, onethird of the population increase was due to natural growth and two-thirds to immigration. By the 1680s the peasant population in the Ukrainian territories was about half a million people; it doubled by $1720 .{ }^{37}$ By 1678 , 3.7 million peasants had emigrated and settled in Siberia, the northwestern areas, the Urals, the southeastern steppe, and the Volga. ${ }^{38}$ As a whole, the population of Russia increased from 7 million in 1600 to about 9 million in 1678, 14 million in 1719,17 million in 1762 , and 21 million in $1782 .{ }^{39}$

In summary, in seventeenth- and early eighteenth-century Russia, colonization relaxed legal constraints on peasants and contributed to the evolution of the institutional and economic relationships in farming regions. Indeed, compensation to the estate owners of Central Russia came from increasingly restrictive access to inhabited estates in these areas. Most of the historiography (Wirtschafter's work being the most important exception) has interpreted these rules as synonymous for increasing power of the nobility over the enserfed peasantry. However, as in the previous centuries, these rules made clearly defined the category of hereditary nobles. From the mid-1730s until the early 1760s, a number of decrees limited the number of people entitled to own and transmit inhabited estates. Servants, servants in monasteries, ${ }^{40}$ soldiers and the lower administrative levels, the clergy, merchants, urban guilds, Cossacks, and raznochintsy 
(people of various ranks) were all prohibited from acquiring or transferring inhabited estates and from establishing krepost' relationships. ${ }^{41}$ Finally, in 1762, factory owners were prohibited from buying and transferring estates with either urban or rural workers. ${ }^{42}$ This did not prevent several merchants and manufacturers from acquiring populated estates and firms ${ }^{43}$ so that in 1812 , the Senate was forced to confirm the decree of $1758 .{ }^{44}$

Last but not least, the evolution of the legal status of the peasantry was strongly affected by the secularization of ecclesiastic lands in 1763, which placed 20 to 25 percent of the peasants under state authority. At the same time, Catherine sought to extend the serf rules of the heartland to the new settlement colonies and offered her close collaborators and top-ranking officials full ownership of lands. Historiography usually cites Catherine making gifts of a million peasants and Paul presenting 800,000 . Actually these figures refer mostly to territories annexed in the Polish partition and in the Caucasus. ${ }^{45}$

In short, from the mid-sixteenth century until the last quarter of the eighteenth century, Muscovite, Russian, and Imperial Russian rules of land ownership did not refer to serfs but mostly aimed to define who was entitled to own and then dispose of populated estates and, as a consequence of that entitlement, who could retain runaways. This solution had far-reaching consequences: it showed that the main goal of the state was not to bind the peasantry but to link the very possibility some estate owners had to possess and transmit them to these owners' acceptance of the state rules regarding the cadastre and thus property. In turn, this put the entitled nobility under the legal control of the state. Third, defining the estate owner rather than the serf meant that the estate owner was informally allowed to exert his or her authority over the serf-and that he or she had permission to exert seigniorial justice and possibly require forms of coerced labor. The state simply delegated the local demesne legal authority to the estate owner. But ultimately, earlier sets of rules meant that while the peasant could not refuse corvées, he could contest the estate owner's ownership. Attempts by nobles to refuse access to their land and deny status to other groups, such as service elites and the bourgeoisie, were constantly mitigated by the ambivalent approach of the state elite, who wished to allow-yet at the same time restrict-the nobility's access, in order to win support for reform and ensure social stability. ${ }^{46}$

The records of numerous court proceedings testify to conflicts between landowners and the administration or among different landowners about the validity of titles of nobility. ${ }^{47}$ Disputes also arose when estates were transferred, dowries were constituted, or inheritances were bequeathed. ${ }^{48}$ Of course, other nobles and the tsarist elites were opposed to such 
practices for both sociopolitical and economic reasons. ${ }^{49}$ Nonetheless, in 1836 , nonhereditary nobles were granted the right to own inhabited estates, though not to transfer them. ${ }^{50}$ The solution then consisted in presenting the sale of noble estates (or a part of them) to non-nobles as loan contracts; this was not necessarily false, insofar as "merchants" often financed indebted nobles, who sometimes were unable to repay their debts. To prevent this from happening, an 1816 law (supported by both part of the nobility and Russian officialdom) prohibited the recording of letters of credit in the name of persons who were not entitled to own and transfer peasants. ${ }^{51}$

Despite these provisions, transactions between nobles and non-nobles continued. To escape the law of 1816, non-nobles used verbal agreements to secure peasants' work or to grant loans to nobles, etc. ${ }^{52}$ These offences multiplied in the ensuing years, and numerous decrees tried to limit the practice of verbal agreements between nobles and non-nobles on the subject of peasants. ${ }^{53}$

Nonetheless, in 1836, the "personal" (nonhereditary) nobles were confirmed in their right to own inhabited estates but not to transfer them. ${ }^{54}$ Those provisions were followed by an increasing number of disputes among nobles, between service nobles and hereditary nobles, or between nobles and the administration. According to the statistics of the Ministry of Justice, in 1845 alone, 6,400 requests for confirmation of the title of noble were submitted, only half of which were validated. ${ }^{55}$ From this perspective, the rules paved the way to a closer focus on a legal definition of illegal bondage. All transactions made between nobles and those who were not entitled to possess populated estates were illicit and therefore gave rise to illegal possession and illegal bondage. A law in 1833 prohibited any new bondage, even if the parties agreed to it. ${ }^{56}$ Limitation on the mobility of peasants residing on an estate that owed a debt to a non-noble was also forbidden. ${ }^{57}$ Several other rules followed during the first half of the nineteenth century, which in fact precipitated a broader process in which administrative and legal condemnation of bondage opened the way to large-scale administrative and judicial emancipation.

\section{Changing Legal Status: Administrative Procedure or Court Proceedings}

The ways in which economic and social actors appropriate legal rules have been the subject of a huge number of studies in sociology, economics, history, and anthropology, and, of course, among legal scholars. In social and economic history, the same approach has been developed for different countries and different periods, and Russian studies, too, have 
recently developed similar methods of analysis. ${ }^{58}$ However, it is widely accepted that peasants had few legal rights in eighteenth-century Russia; indeed, some scholars consider this to have been the case right up to the legal reforms of 1864 .

Such arguments require a serious assessment. In fact, the ability to take legal recourse to capture social and economic assets depends on the distribution of legal rights, as well as on legal procedures and the precise wording of laws. A clear distinction has to be made between administrative law, on the one hand, and civil and penal law, on the other. In tsarist Russia, administrative law largely dominated the legal landscape and often overlapped with civil and penal law. We thus need to clarify which kind of rules regulated the institutional and social life of peasants; how they were implemented; and with which issues they dealt. We may start with administrative rules in the strict sense. In fact, many laws were passed during the first half of the nineteenth century to facilitate administrative changes to the legal status of peasants. They were reforms that responded simultaneously to particular claims, to momentary worries, and to a more general attitude on the part of Russian elites. Political stability, economic efficiency, paternalistic criticism of serfdom, and the particular economic interests of the state or some of the nobility all played a part, to different degrees, in reform. ${ }^{59}$

In general, the matter concerning the rules and their implementation was the transfer of peasants belonging to private estates to the legal category of state peasants. Peasants on noble and private estates were first distinguished from state peasants after the seventeenth century. ${ }^{60}$ State peasants had certain obligations only to the state, for example to pay an annuity, usually in money, sometimes in kind. They were also obliged to perform work of public interest, which is usually mentioned to justify the existence of forced labor and serfdom in this category. At the same time, state peasants could work in cities in trade and industry, provided they had the required documents. ${ }^{61}$ Catherine II even included representatives of state peasants in her legislative commission who were assigned to define the rights and obligations of the main social groups. ${ }^{62}$ In 1842 , state peasants were freed from any obligation toward the state, apart from taxes.

Starting from this premise, we can study the rules allowing a peasant from a private estate to be reclassified as a state peasant. The first such reform was adopted by Alexander I, who ascended the throne in 1801 and gave the impression of being willing to introduce far-reaching reforms. In 1801 he allowed merchants, townspeople, and state peasants to own unpopulated estates, by which he intended to partially challenge the nobles' monopoly on land ownership. In 1803, a decree created a 
classification of svobodnye khlebopashtsy, which included free farmers whom, at his own discretion, the landowner could exempt from any obligation, apart from those obligations made by peasants concerning plots of land given to them by the overall owner of the land. Those agreements were legally binding on both peasants and landowners. ${ }^{63}$

The influence of German and Russian intellectuals, as well as pressure from some of the noble elites, encouraged the reforming attitudes of the tsars, in particular Alexander, whom Count Rumyantsev pressed to adopt this provision. Rumyantsev had sought permission to free some of his serfs and sell land to them, and the positive response to his request became the basis for broader reform.

This provision by Alexander was supposed to lead to an improvement in agriculture while also being advantageous to estate owners; and according to the estimates of Hoch and Augustine, between 1833 and 1855 alone, 58,225 people were emancipated on its basis, ${ }^{64}$ a figure that rose to 114,000 male peasants, between 1803 and 1855. However, despite several attempts to go further, Alexander did not adopt other reforms of the same kind. The Napoleonic Wars and opposition by some groups of nobles and high-ranking officials seem to have played a role in his change of heart. ${ }^{65}$

The next tsar, Nicholas I, also spent some time projecting reforms before adopting concrete rules. They occurred in the broader realm of Pavel Kiselev's reforms between 1838 and 1842, which radically modified the status of state peasants. Peasants' general and professional education was taken into account, while their financial burdens and their obligations toward the state were no longer assessed per head, but in conformity with the value of each individual peasant's land or income from nonagricultural activities. ${ }^{66}$

Kiselev ordered a general inquiry into agriculture and the peasantry. His final report concluded that the labor of peasants with no statutory obligations to landowners was more productive than coerced labor; however, on the basis of that report, Kiselev and Nicholas I maintained that the present difficult situation of agriculture and the extent of coerced labor was the result of the fact that some landowners had abused their power and had extended the power of their patronage over the peasantry. Limitation of those abuses thus became a precondition for deeper reforms. At the same time, it was argued that peasants should not be freed from their illegal bondage without being given the opportunity to acquire their own land. In fact, as the reforms experienced in the Western borderland had proved, freedom without land would lead to a clear worsening of the peasants' circumstances and hence to social and political instability. 
Accordingly, in 1842, a new decree was adopted. It was conceived as the direct successor to the 1803 decree, but with the major difference that the contractual agreement between an estate owner and peasants would not be left to the free will of the estate owner but would be regulated by law. If the peasants involved did not redeem the value of the land, estate owners would retain the right of full patrimonial ownership of it and the peasants would receive plots for their use. A particular category of peasant was created - the peasant who had an obligation (obiazannye krest'ianie) toward noble landowners and who fitted neither the category of private estate peasants in the strict sense (pomeshchichie krestiane) nor that of servants (dvornye liudi).

As with previous rules, this new decree referred specifically to peasants, private peasants, and rural inhabitants, but not to serfs, who were subject to other legal rules (uslovnoe pravo); peasants no longer had any general obligations toward landowners, except those concerning the plot received when the contract with the property owner was signed. ${ }^{67}$ Peasants concluded contracts with landowners stipulating the size of their allotment and the level of their obligations. From the adoption of the new law until 1858, a total of 27,173 male peasants and their families were affected by the decree. ${ }^{68}$

In 1841 , peasants whom private nobles had allotted freely to monasteries or charitable institutions were also reclassified due to the prohibition on the ownership and transfer of serfs by these institutions. ${ }^{69}$ About 8,900 people were thus transferred to the category of state peasants, and the institutions to which they belonged were compensated by the state. ${ }^{70}$

Tsar Nicholas did not stop with these reforms. In 1844, two new laws facilitated the reclassification of dvornye liudi (servants); the first one freed the servants' masters from any responsibility for the payment of taxes, while the freed servants were exempt from military service and taxation until the next revision. The second law facilitated a change of legal status for cases in which a landowner mortgaged his estate to certain credit institutions. According to a study at the time, in 1851 alone, 11,000 meshchane (merchants) from eleven provinces were said to have benefited from those rules, having been previously the peasants of private owners. ${ }^{71}$

About 19,000 working peasants connected to private factories were freed between 1840 and 1851, and during the same period, many mines had recourse to "temporary workers" (nepremennye or urochnye rabotniki) who were registered as private peasants at the time of the eighth revision. These facts were denounced years later, and a court decision was made for the ninth revision only in 1851 . At that time, 53,900 men working in the mines were transferred to state estates as peasants. ${ }^{72}$ All of 
these rules reclassified private peasants into other categories and thereby erased their obligations toward their landlords.

Administrative emancipation sometimes occurred for other reasons. As we have seen, under tsarist law, mortgaged estates put up for auction were especially targeted. State and noble elites agreed that indebted landowners must be helped, in order to prevent their lands from falling into the hands of "speculators" and bourgeoisie. To that end, along with the state itself, local peasants were granted priority in acquiring such lands. In 1847 the peasants from auctioned estates could buy land and purchase their own freedom to move. ${ }^{73}$ That same year, however, the Ministry of Estates, set up in 1838, was obligated to buy private estates put up for auction. As a result, 178 estates were taken over between 1838 and 1855 , with a population of about 58,275 serfs consequently transferred to the state. Beginning in 1842, the same ministry also began taking over estates belonging to "isolated peasants" (odnodvorcheskie krest'iane). By 1858 , about 8,000 peasants had been taken over by the state in this way. In 1845, the administration in charge of feeding horses in the province of Voronezh bought the estate of Count Orlov, with its 6,562 inhabitants, who became state peasants. The public treasury $(u d e l)$ took over estates as well: between 1831 and 1860 it bought fifty-two estates in the provinces of Simbirsk and Orel, with about 25,000 inhabitants. In all, between 1833 and 1858 alone, the legal status of 343,575 male peasants changed due to mass emancipations by the state: they ceased to be private-estate peasants and became state peasants and sometimes meshchane.

General and administrative law regarding emancipation had a cumulative effect not only on mortgaged estates, but also on the terms of succession. Thus two new laws adopted in 1836 and 1839 stipulated that if a landowner left no heirs, or no heirs who could legitimately own serfs, the peasants would become state peasants, whereas the servants could register in cities as meshchane. ${ }^{74}$

In 1841, a new law prohibited the succession of landless nobles or landless owners of peasants. Consequently, between 1841 and 1858, the number of landless nobles dropped from 17,700 to 3,633 , and their serfs from 62,000 to $12,045-$ a dramatic fall, even taking into account the possibility that some of the serfs had been sold to other nobles. ${ }^{75}$

The voluntary redemption of peasants' obligations and thus a change in legal status at the discretion of the master was already provided for in the seventeenth and eighteenth centuries. But it is difficult to estimate the number of such redemptions, as no systematic, province-by-province studies are available, although notarial archives (krepostnye knigi) and estate archives provide useful information. The impression given by the mass of archives is that voluntary acts of redemption increased during the 
nineteenth century in response to both tax support and legal simplification, as provided by the tsarist rules. ${ }^{76}$ According to estimates at the time, the ninth revision of 1851 , held in twelve provinces (guberniia), resulted in a change in legal status for 11,000 meshchane. ${ }^{77}$ The tsarist authorities collected relatively detailed, though not cumulative, data on such individual acts, between 1860 and 1868; the records take up twenty-five volumes and give a wealth of information on the state of the population in Russia's provinces and empire. ${ }^{78}$

These acts were part of the paternalistic relationships that defined the system; they set an example for the mass of peasants to engage in cordial relations with their landowners, with a view to their possible emancipation. The pace of these acts accelerated during the nineteenth century in response to incentives from the authorities and the compensation guaranteed to noble landowners. ${ }^{79}$

Yet the changing of legal status also resulted from the increasing number of legal proceedings brought by peasants themselves against their masters. Until the 1770s, there were no special courts in Russia for peasants, who, until then, were forced to apply to nobles and their courts to request emancipation - a system that considerably reduced attempts to initiate proceedings. The situation changed in 1775 with the introduction of peasant courts, accompanied by a clear-cut legal differentiation between ownership of things and rights over human beings. Throughout the nineteenth century, these issues were frequently the subjects of court rulings. Peasants themselves were sometimes able to demonstrate in court that the landowner or master concerned was not entitled to own the estate ${ }^{80}$ Proceedings brought by peasants became so numerous that between 1837 and 1840 the Senate actually decided to put a stop to cases involving serfs still living with their masters. ${ }^{81}$ Overall, between 1833 and 1858 , the Senate recorded 15,153 cases of illegal bondage, while the provincial courts dealt with 22,000 cases of this type. ${ }^{82}$

Naturally, these positive outcomes should not obscure the difficulties confronting peasants who tried to bring proceedings against a noble or someone claiming to be noble. The rulings of local courts often differed considerably, and several judges considered peasant petitions inadmissible and even refused to grant them the right to appeal. ${ }^{83} \mathrm{~A}$ number of cases of corrupt judges being influenced by noble landowners were also recorded. Finally, the investigations of proceedings went slowly, and it often took ten years to reach a conclusion. ${ }^{84}$

Measures aimed at changing this state of affairs were not adopted until the end of the 1840s, when a new law facilitated the legal proceedings of all those who considered their obligations toward estate owners to be illegal. ${ }^{85}$ The importance of these proceedings is confirmed by the increasing 
number of peasants establishing themselves in town and formally and informally changing their legal status.

\section{Peasants in Town}

Conventional historiography-both in Russia and in the Western countries-complained about the lack of cities in tsarist Russia and, in particular, of "free" towns headed by "bourgeois" groups. In this perspective, Russian towns, unlike their Western counterparts "did not make free" and were not centers of industrial activity, but rather were administrative-military locations. ${ }^{86}$ The underlying model, common to Marxist and liberal views, is that politically, the town in the West "made free" and that from an economic standpoint it encouraged the division of labor and the emergence of the modern world, i.e., trade and industry. As Pirenne, Braudel, Tawney, the German historical school, and many others have put it, the town has been the engine for the emerging of the modern capitalistic and "bourgeois" world.

More recent historiography has partially revisited this approach; for example, Mironov has clearly demonstrated that if at the end of the eighteenth century, two-thirds of towns of European Russia were still agrarian (with agrarian activities strongly dominant) and almost all (94 percent) had significant agrarian activities; during the first half of the nineteenth century, agrarian activity within the towns greatly declined, as did purely military and bureaucratic activity. Farming as an independent functional kind of activity ceased to exist in 19 percent of the towns in European Russia. It played a secondary role in 44 percent of the towns, an important role in 15 percent, and the leading role in only 22 percent of towns. At the opposite end of the spectrum, trade and manufactures developed strongly in most Russian towns. ${ }^{87}$

This book develops this view further, addressing the following questions: Was the legal separation between the town and the countryside really important and effective? And is the persistent peasant-worker a feature of "backward" countries?

Indeed, the Ulozhenie of 1649 did not prevent peasants from establishing themselves in town. On the contrary, this opportunity was openly extended to servants and hired laborers. However, as people began to take advantage of these opportunities, a decree of 24 November 1699 declared that only peasants who had already lived in towns and possessed stores or craft workshops there-or those who were engaged in itinerant trade-were eligible for inclusion in the urban taxpayers' list. Those who did not wish to be a part of this list were again barred from engaging in these enterprises and were ordered to "live under their lords." Peasants 
who sold goods hauled in from the countryside for wholesale prices, as authorized by the Ulozhenie, were not subject to these provisions. Furthermore, in 1709 , peasants who did not wish to register in the posad' (urban tax rolls) were authorized to participate in urban trade only if they paid a 10 percent tax on the value of their enterprises ${ }^{88}$ The peasants' commercial activity was in the municipal interest, because peasants paid local taxes, whereas the majority of urban guilds were strictly opposed to allowing them to penetrate their territory. The cabiers des doléances sent by the legislative commission, which were set up by Catherine, testified to these multiple and divergent interests ${ }^{89}$ Registered shopkeepers protested against stallholders who did not pay taxes and also against the fact that they were competitors, that they employed stallholders in place of local apprentices, that they granted loans outside the urban network, etc. This framework was later complicated by the fact that the residual category of raznochintsy (people of different rank), ${ }^{90}$ who were theoretically entitled to register on the list of urban inhabitants, encompassed individually emancipated serfs, certain urban categories (meshchane), children of merchants, priests who did not represent the profession of their fathers, isolated households (odnodvortsy), service personnel of lower rank (starukh sluzheb sluzhilye liudi), and the kabal'nye liudy-peasants who had worked for a landowner while still likely to be included in urban groups. Thus several decrees in 1732, 1737, 1743, and 1744 required city authorities to register on their lists all raznochintsy who were not yet included among taxpayers. ${ }^{91}$ However, the measure was difficult to implement because the category evolved over time and differed according to the various legal sources (tax, administrative, and criminal). Catherine's Charter of Rights and Privileges (1785) remained in effect until 1870. It defined the town population as the community of all male inhabitants over twenty-five years of age possessing real estate or exercising a trade yielding fifty rubles per year. It is nevertheless significant that, of the six urban groups, only three (merchants, artisans, and meshchane) actually appeared in the form of an estate corporation and led municipal affairs. This means that unlike some official tsarist declarations and historians' lieux communs, merchants and "Third Estate" groups actually controlled the Russian towns. Occasional conflicts displayed the political and economic tensions between these groups - not at all the "visible hand" of the Russian state.

Illegal shopkeepers were constantly hunted down during the seventeenth, eighteenth, and nineteenth centuries. ${ }^{92}$ Regulations in the $1720 \mathrm{~s}$ and during the time of Catherine, as well as the list of segments and industrial firms drawn up by the governors between 1817 and 1820, testify to the efforts ${ }^{93}$ undertaken by the municipalities and by the state and 
trade officials. In theory, merchant stallholders, hawkers, and occasional merchants made up the largest pool of those merchants described as illegal. However, applying the legal rules was no easy task-not only because of arbitrary enforcement and bribery, ${ }^{94}$ but also because the interests of municipalities and certain traders and trading peasants converged. Let us take the case of nonresidents who rented stores and shops. Naturally it was difficult to rent a shop in the city without being registered on the list of taxpayers and residents. Thus the stallholders most often rented premises in the city outskirts and inner suburbs. For example, around the mid-eighteenth century, in the suburb of Blagovescenskaja, near NizhnyiNovgorod, 265 peasants and raznochintsy had shops, but only 112 were registered on the city lists. They were, however, registered on the lists of Blagovescenskaja. This led to protests by merchants and the city of Nizhnyi-Novgorod, especially as its inhabitants bought their supplies in the inner suburbs. ${ }^{95}$ In other words, shopkeepers of nonurban origin or who came from other cities would take advantage of the tax competition between cities and towns to engage in trade while paying as little as possible. Several municipalities decided to exercise a less repressive and more attractive policy. For example, more and more municipalities rented their own market stalls and shops, thereby receiving leases and demanding payment of obrochnye den'gi (local tax); but they did not require registration or payment of ensuing expenses, which, of course, caused protests from local shopkeepers. ${ }^{96}$

Similar situations occurred with artisans who were not registered but owned a workshop in the city. When a state inspector visited the town of Tula in 1844, he found certain variations in the number of guild masters and workers listed in the municipal records of previous years; in 1842 the town had recorded only 55 masters, while there had been 400 in 1840 and 560 in $1843 .{ }^{97}$

Some municipalities readily rented such premises even without official registration on the list of residents and urban taxpayers, but in exchange for payment of a tax. In the eighteenth and nineteenth centuries, this solution gave rise to protests from the guild or the community concerned. ${ }^{98}$ Yet these same institutions were ready to avert their gaze when time came to employ the same unregistered "immigrants" as apprentices or workers. ${ }^{99}$ In this case, too, peasants and stallholders took advantage of these complex attitudes to slip through the net of urban regulations. On the whole, a listing of industrial enterprises, compiled from data reported by provincial governors in 1817-20, identified factory owners who were third-guild (the lowest one) merchants, lesser townspeople, peasants, and members of other nonurban categories. In Voronezh, a simple comparison of police documents with municipal records revealed that almost all 
the town's tailors ( 50 masters and 440 workers, according to police files) had not registered with their guilds. ${ }^{100}$

According to official sources from 1845, only 42 percent of Moscow townspeople possessed a demonstrable trade. ${ }^{101}$ In 1859, Moscow's passport office registered 142,000 arrivals (a rise of 16,000 over the 1847 figures), this at a time when the city numbered 370,000 permanent residents. Most of these migrants stayed for a few months, some for years. How many others arrived without any legal travel documents is impossible to estimate. Not only peasants, but also city dwellers, engaged in petty trade between the town and the countryside. They bought up farm goods and rural handicraft products and sold them at a small profit to the local inhabitants. Among these petty traders, some enrolled as merchants solely to obtain exemption from conscription for their sons. A nineteenth-century Russian scholar estimated that many of the 200,000 merchants of the third guild had entered the lists solely to avoid conscription-for when the privilege disappeared in 1870, their numbers dropped sharply.

This commercial activity was largely responsible for the fact that the decline of merchants into the petty-bourgeois estate (meshchane) could be somewhat counterbalanced by the rise of new merchants. For example, in Moscow, official records for the years 1830-45 indicate the entry of 4,200 meshchane into the city's merchant estate. ${ }^{102}$

The attitude of noble landowners toward the illegal presence of peasants and peasant- merchants or artisans in the city depended not only on the landowner, but also on the current economic situation. Most landowners were favorable to them, above all during the first half of the eighteenth century and again in the nineteenth century, that is, at times when they found it advantageous to allow their peasants to engage in various activities and benefited considerably from the nonagricultural revenues of this population. The archives of estates and towns provide the nominal list of peasants entering guilds as merchants or artisans. ${ }^{103}$

However, other landowners were opposed and preferred to keep peasants on the estate. In these instances, the noble landowners and their representatives at the court were quick to blame the municipalities, accusing them of hiding fugitives for tax reasons or in the interests of their merchants and master artisans. ${ }^{104}$ Such conflicts spurred state regulation of these problems. In 1824, a law was passed admitting the distinction between urban residents (posadkie) and tradesmen exempt from residence and certain tax obligations but still required to pay an additional tax to gain certain privileges (official access to shop rental, market stalls, etc.). ${ }^{105}$ Nobles, peasants, and other nonresidents could buy certificates (svidetel'estva), allowing them to engage in trade within certain limits. The municipalities then put the various types of certificates up for sale at 
different prices; a peasant, for example, could choose among six different certificates.

The attempt to legalize practices that were already widely adopted took hold in 1832, when the Svod zakonov (Anthology of Laws), referring, as at the time of Catherine, to srednii rod liudei (people of intermediate origin), divided the urban population into three main groups: merchants belonging to guilds and honorary citizens; meshchane and posadkie (enrolled urban population); and artisans. Yet these measures did not succeed in preventing conflicts.

Between 1847 and 1861, several urban communities (including Smolensk, Nizhnyi-Novgorod, and Kazan') refused to register on their lists anyone among the raznochintsy who could not pay their taxes. ${ }^{106}$ Sometimes the conflicts were settled by the Senate ${ }^{107}$ and sometimes by the municipalities themselves. For example, in Samara, in 1842, the municipality placed the nobility and civil employees with rank in the same category; however, most of the other urban regulations during this time made a sharp distinction between these two categories. ${ }^{108}$

An important consequence of this scattered evidence is that the urban population and urban activity in pre-reform Russia has been largely underestimated-illegal and undeclared residents should be added to the numbers, as should the massive temporary migration to towns of those people usually recorded as peasants in both private and state estates records. In proto-industrial areas, this proportion could be as much as a quarter of the rural population, and it tended to rise during the first half of the nineteenth century. The reverse was also true-townspeople migrated to villages in search of work, while many registered urban citizens received plots of communally owned city land, which could be bought, sold, rented, and exchanged. In the cities of the central agricultural regions, numerous townspeople and merchants earned their living primarily from farming.

These fluid boundaries between the cities and the countryside testify to two main issues in Russian history: First, legal concerns were much less constraining than is usually acknowledged, and this was so not only because people circumvented the law but because the law itself pushed in this direction. Tsarist restrictions on mobility should not be taken as being synonymous with opposition to urbanization. Barriers among groups were not impermeable; the basic principle of the system was to promote stability and growth. Second, interpenetration between the city and countryside was neither necessarily a symptom nor a cause of backwardness. Russian actors did not behave as some European models would predict-they were neither "pure merchants" nor "pure proletarians"; the countryside and its development were no less important to them than 
was their interaction with the town; there were no classes in the Marxist sense nor individual actors (liberal approach) nor a rigid estate system, but rather a coexistence of all these ways of social and juridical stratification. Was this necessarily a symptom of backwardness?

\section{Conclusion: Legal Status and Economic Dynamism in Imperial Russia}

Two main elements are usually called upon to explain serfdom: the state and noble landowners. Historians talk about the status in two different, thoroughly incompatible ways. For some, serfdom is a result of the strength of the autocracy, whereas others emphasize the opposite, that serfdom was a result of the weakness of the tsarist state, which is said to have left the nobles free to enserf the peasants.

These two interpretations are partial, if not erroneous, in that they do not take into account the close interaction between the state (or rather, certain administrations and certain leaders) and Russian society. The state was more than an administration, and, above all, administration was not limited solely to taxation and the police; the state was also the law, and from that standpoint, the dominant interpretations miss the essential point when they assert that the autocracy imposed a law that was not really law or, on the contrary, that it was incapable of controlling relationships in the countryside. In reality, tsarist law recognized and relied on other legal sources, including seigniorial law and its courts, and these rules mutually legitimated each other. The disputes between nobles and merchants and the considerable emancipations of peasants through legal and/or administrative channels testify to the importance of this element. However, the law was hierarchical; the various social groups had varying access to the courts and to jurisdictions. In other words, while it is not true that Russian society had no law, it would be a mistake to equate it with the rule of law as defined, for example, in France or in the United States at the end of the twentieth century. The way law was conceived and implemented shaped social and economic hierarchies. The mobility of peasants on private estates was considerably restricted; however, these restrictions were never definitive and changed according to the estate and the economic situation. As a whole, these provisions corresponded to a reorganization of the administration and the introduction of a land registry established to settle conflicts between nobles and merchants, or even within noble families, over the transfer of estates and the attribution of noble status.

Here we find interesting differences from Western colonial slavery, beyond what we have already mentioned: the lack of race concerns, the 
importance of the peasant commune, and the contract signed between peasants and landlords. In particular, emancipation did not occur as a single act, as in Western colonies and the United States (even if, as we will see, in the British Empire this took the form of a transitional apprenticeship period for slaves). Almost half the Russian peasants had been emancipated from their obligations toward private owners in the decades before the official abolition of serfdom. Compared with the administrative procedures of manumissions, the emancipations resulting from to judicial litigations were a tiny minority-about 12,000 people against a million-yet this amount corresponds to our extremely partial investigations into some local courts and Senate decisions. And, even so, this is already close to the number freed slaves resident in Britain in the early 1770s (estimated between 10,000 and 15,000) and more than twice the number of those with that status residing in France. ${ }^{109}$ In short, unlike British and American slavery, Russian emancipation was already in progress before the official abolition of serfdom, resulting from administrative and political acts, even if one cannot neglect judicial issues. These dynamics can be interpreted as a limitation of Russian civil society, and certainly it was. At the same time, if in Britain the abolitionist movement involved many social groups, in France public opinion was much more passive and silent and therefore abolition of slavery was essentially a topdown act. ${ }^{110}$ Among the specific forms of administrative manumission, military service played a major role in Russia; this too distinguished Russian emancipation from that in contemporaneous Britain and the United States. Indeed, in the American colonies, during the War of Independence, some leading actors sought to play this card: slaves who would volunteer to serve would be promised freedom at the end of the war. Unfortunately, this measure was quite rarely carried out, because of the opposition of slave owners. ${ }^{111}$

Other forms of Russian administrative emancipation before 1861 were related to the tsarist elites' desire to exert economic, social, and political control over the nobility; reforms seemed to promise the preservation of autocracy and its social order. This strategy preserved shielded Russia from a dramatic abolition process such as the one that took place during the U.S. Civil War and its aftermath. Protests against the definitive emancipation of serfs came from parts of the provincial nobility, but this was far from the dimensions of a civil war as experienced in the United States.

Of course, one may argue on the one hand that Russia avoided strong conflicts at the moment of the emancipation precisely because of the smooth process of reforms, but that on the other hand, the country lacked a deep transformation process after the reforms. According to this view, the limitations of reforms would exacerbate tensions during the 
second half of the nineteenth century and lead to the revolution. We will have occasion to test this view in the last chapter; before that, we first need to examine whether, despite the institutional long-term evolution of serfdom and the lack of official rules binding the peasantry, bondage was not informally practiced on the estates. Was not serfdom practiced beyond the complexity of legal texts and the eventual changing legal status of social actors?

Starting from this point, we may question to what extent market development was compatible with labor service in the countryside and with the persistent peasant worker in proto-industry and manufacture. Answering this question, in turn, will help us understand the economic and social evolution of Russia after 1861.

\section{Notes}

1. Marc Bloch, "Serf de la glèbe. Histoire d'une expression toute faite," Revue historique, 36 (1921): 220-42.

2. Guy Bois, La crise du féodalisme (Paris: Presses de Sciences-Po, EHESS, 1976); Georges Duby, Les trois ordres ou l'imaginaire du féodalisme (Paris: Gallimard, 1978); Pierre Bonnassie, From Slavery to Feudalism (Cambridge: Cambridge University Press, 1991); John Munro, "Crisis and Change in Late Medieval English Economy," Journal of Economic History 58,1 (1998): 215-19; Tom Scott, ed., The Peasantries of Europe from the Fourteenth to the Eighteenth Centuries (London: Longman,1998); Paul Freedman, Monique Bourin, eds., Forms of Servitude in Northern and Central Europe (Turnhout: Brepols, 2005).

3. Robert Brenner, "Agrarian Class Structure and Economic Development in Pre-industrial Europe," Past and Present 70 (1976): 30-74; Trevor Aston, Charles Philpin, eds., The Brenner Debate: Agrarian Class Structure and Economic Development in Pre-industrial Europe (Cambridge, Cambridge University Press, 1985); Michael North, From the North Sea to the Baltic: Essays in Commercial, Monetary and Agrarian History, 1500-1800 (Aldershot: Ashgate, 1996); Melton, "Population Structure," 297-324; Raeff, The Well-Ordered Police State; Christoph Shmidt, "Uber die Bezeichnung des Stände (sostojanie-soslovie) in Russland seit dem 18. Jahrhundert," Jahrbucher für Geschichte Oesteuropas 38 (1990): 199-211; William Hagen, Ordinary Prussians: Brandenburg Junkers and Villagers, 15001840 (Cambridge: Cambridge University Press, 2002). W. Trossbach has radically denied the significance of serfdom in the early modern period. See W. Trossbach, "Südwestdeutsche Leibeigenschaft in der Frühen Neuzeit-eine Bagatelle?" Geschichte und Gesellschaft 7 (1981): 69-90.

4. Blum, Lord and Peasant; Alexander Gershenkron, Economic Backwardness in Historical Perspective (Cambridge, MA: Harvard University Press, 1962); Hellie, Enserfment and Military Change; Peter Kolchin, Unfree Labor; Bush, Serfdom and Slavery; Daniel Field, The End of Serfdom: Nobility and Bureaucracy in Russia, 1855-1861 (Cambridge, MA: Harvard University Press, 1976).

5. Hoch, Serfdom and Social Control.

6. Petr Struve, Krepostnoe khoziaistvo. Issledovaniia po ekonomicheskoi istorii rossii v XVIII $i$ XIX $v v$ [The serf economy: studies on the economic history of Russia, eighteenth to nineteenth century] (Saint Petersburg: 1913); Ivan D. Koval'chenko, Russkoe krepostnoe krest'ianstvo v pervoi polovine XIX $v$. [The Russian serf economy during the first half of the 
nineteenth century] (Moscow: Nauka,1967); Edgar Melton, "Proto-industrialization, Serf Agriculture, and Agrarian Social Structure: Two Estates in Nineteenth-century Russia," Past and Present 115 (1987): 73-81; Melton, "Enlightened Seignorialism," 675-708. See also Evsey Domar and M. Machina, "On the Profitability of Russian Serfdom," The Journal of Economic History 44, 4 (1984): 919-55.

7. Michael Confino, Domaines et seigneurs en Russie vers la fin du XVIIIe siècle: Étude de structures agraires et de mentalités économiques (Paris: Mouton, 1963); Systèmes agraires et progrès agricole en Russie aux XVIIIe-XIXe siècles: Étude d'économie et de sociologie rurales (Paris: Mouton, 1969). Hoch, Serfdom and Social Control; David Moon, The Abolition of Serfdom in Russia, 1762-1907 (London: Pearson, 2001); David Moon, The Russian Peasantry, 1600-1930 (London: Longman, 1996). Elise Kimerling Wirtschafter, Structures of Society: Imperial Russia's "People of Various Ranks" (Dekalb: Northern Illinois University Press, 1994); Elise Kimerling Wirtschafter, Social Identity in Imperial Russia (Dekalb: Northern Illinois University Press, 1997).

8. Roger Bartlett, "Serfdom and State Power in Imperial Russia," European History Quarterly 33, l (2003): 29-64; David Moon, "Reassessing Russian Serfdom," European History Quarterly 26,1 (1996): 483-526.

9. Examples of this are found in Tracy Dennison, The Institutional Framework of Russian Serfdom (Cambridge: Cambridge University Press: 2011).

10. Ian Blanchard, Russia's Age of Silver: Precious Metal Production and Economic Growth in the Eighteenth Century (New York and London: Routledge, 1989).

11. Polnoe sobranie zakonov Rossiskoi Imperii (hereafter PSZ) [Full collection of laws of the Russian Empire], three series: I: 1649-1825, 46 vols. Saint Petersburg, 1830. II: 18251881, 55 vols. 1830-1884; III: 1881-1913, 33 vols. 1885-1916.

12. Entsiklopedicheskii slovar' Brokgauz-Efron, vol. XVI, Saint Petersburg 1895, entry krest'ianie: 681. Also Slovar' russkogo iazika XVIII veka [Dictionary of the Russian language of the eighteenth century] fasc. 10, edit. Sorokin, Saint Petersburg, 1998, entry krepostnoi.

13. Richard Hellie, Muscovite Society, Chicago, syllabus division, 1967; Richard Hellie, The Ulozhenie (Law Code) of 1649 (Irvine, CA: Charles Schlacks, Publisher, 1988); "The Law Code of 1649" and "Muscovite-Western Commercial Relations," in Readings in Russian Civilization, ed. Thomas Riha. 2nd edition (Chicago: University of Chicago Press, 1969), 154-72.

14. The term "peasant," so widely used, should be subjected to a deep semantic and historiographic analysis for Russia and other countries. The word refers to completely different people depending on the author, the period in question, etc. On this, see William Hagen, "Subject Farmers in Brandenburg-Prussia and Poland: Village Life and Fortunes under Manorialism in Early Modern Central Europe," in Bush, Serfdom and Slavery, 296-310; Alessandro Stanziani, "Chayanov, Kerblay and les shestdesiatniki: une histoire globale?" Cabiers du monde russe 45, 3-4 (2004): 385-406.

15. Mikhail F. Vladimirskii-Budanov, Obzor istorii russkogo prava [Short history of Russian law], 6th edition (Kiev, 1909).

16. Daniel Kaiser, The Growth of the Law in Medieval Russia (Princeton: Princeton University Press, 1980). Kaiser's book provides a detailed analysis of the different editions of the Sudebnik in 1550, 1589, and 1606.

17. Daniel Field, Rebels in the Name of the Tsar (Boston: Houghton Mifflin, 1976), 2-7; R.E.F. Smith, Peasant Farming in Muscovy (Cambridge: Cambridge University Press 1977); Arcadius Kahan, "Natural Calamities and their Effect upon the Food Supply in Russia," Jahrbücher für Geschichte Osteuropas 16, 3 (1968), 361-371.

18. Jerome Blum, "Prices in Russia in the Sixteenth Century," The Journal of Economic History 16, 2 (1956): 182-99; Arkadii Man'kov, Tseny I ikh dvizhenie v russkom gosudarstve XVI $v e k a$, [Prices and their dynamics in the Russian state in the sixteenth century] (Moscow, Leningrad: Nauka, AN SSSR, 1951). 
19. Aleksandr'I. Kopanev, "Naselenie Russkogo gosudarstva v XVI v" [The population of the Russian state in the sixteenth century], Istoricheskie zapiski 64 (1959): 233-54.

20. Confino, Domaines; Hellie, Enserfment.

21. Hellie, Enserfment; Peter Perdue, "Military Mobilization in Seventeenth- and Eighteenth-century China, Russia, and Mongolia," Modern Asian Studies 30, 4 (Oct. 1996): 757-93.

22. Robert Jones, "The Nobility and Russian Foreign Policy, 1560-1811," Cabiers du monde russe et soviétique 34, 1-2 (1993): 159-70.

23. Moon, The Abolition.

24. Cadastre documents (Pistsopye knigi) are largely available in RGADA in a large number of fonds, among which see f. 1239, opis' 3 , chast 17, 69-72, 74, 76, 86-87 (cadastres of Moscow district, 1674-1681); fond 396, opis' 2, ch. 5 (1616-1732), Smolensk, and several other districts; fond 1209 (prilozhenie arkhiv premikikh votchnikh del, 1565-1692), opis' 1, ch. 1-3, opis'2, ch. 1-2, opis' 16-72.

Fifteenth- and sixteenth-century cadastres were published in Pistsovye knigi Moskovskogo gosudarstva (ed. N.V. Kalachov), Saint Petersburg, 1872 and 1877. On cadastres, see Henry Eaton, "Cadasters and Censuses of Muscovy," Slavic Review 26,1 (1967): 54-69. The most complete list of published sixteenth and seventeenth cadastral records can be found in S.V. Voznesenskii, Materialy dlia bibliografii po istorii narodov SSSR XVI-XVIIvv [Materials for bibliography of the history of the Soviet people, sixteenth to seventeenth century] (Leningrad: Gos. Isz. 1933).

25. Hellie, Enserfment, 108.

26. Robert Crummey, "Sources of Boyar Power in the Seventeenth Century," Cabiers $d u$ Monde Russe et soviétique 34, 1-2 (1993):107-18.

27. Hellie, Enserfment.

28. Arkadii Man'kov, Razvitie krepostonogo prava v Rossii vo vtoroi polovine XVII veka [The development of serfdom in Russia during the second half of the seventeenth century] (Leningrad: Nauka,1962).

29. A new Russian edition (Sobornoe ulozhenie 1649 g.) and commentaries was published in 1987 under the supervision of A. Man'kov. For an English translation, see Richard Hellie, Muscovite Society (Chicago, University of Chicago Press, 1967); idem, The Muscovite Law Code (Ulozhenie) of 1649 (Irvine, CA, 1988); "The Law Code of 1649" and "Muscovite-Western Commercial Relations," in Readings in Russian Civilization, 2nd ed, ed. Thomas Riha (Chicago: University of Chicago Press, 1969), 154-72.

30. Ulozhenie, chapter 11, n. 10.

31. Hellie, Slavery; E.I. Kamentseva, "Usloviia zakreposhcheniia novoporiadchikov" [The conditions of enserfment of new settlers] Trudy moskovskogo gosudarstvennogo istoriko-arkhivnogo instituta 7 (1954): 129-54.

32. On peasant mobility, see RGADA, fond 294, opis'2. See also Daniel Morrison, "Trading Peasants" and Urbanization in Eighteenth Century Russia: The Central Industrial Region (New York and London: Longman, 1987); Emilia I. Indova, "Rol' dvortsovoi derevni pervoi poloviny XVIII v. v formirovanii russkogo kupechestva" [The role of the village court during the first half of the eighteenth century in the formation of a Russian bourgeoisie] Istoricheskie Zapiski, 68 (1961): 189-210. A French translation of this article has appeared as "Les activités commerciales de la paysannerie dans les villages du tsar de la région de Moscou (première moitié du XVIIIe siècle), Cahiers du monde russe 5, 2 (1964): 206-28.

33. RGADA, fond 615 (krepostnye knigi mestnyjh uchrezhdenii XVI-XVIII v), opis' l; fond 294 (Manufaktor-Kontora), opis-1-3.

34. Melton, "The Russian Peasantries," 239.

35. Arcadius Kahan, The Plow, the Hammer, and the Knout: An Economic History of Eighteenth-century Russia (Chicago: University of Chicago Press, 1985), 76-77. 
36. TsGIA, fond 379 opis' 1; PSZ, sery 1, vol. 40 n 21779; vol. 32 n. 25150.

37. Melton, "The Russian Peasantries," 227-68.

38. Moon, "Peasant Migration"; Williard Sunderland, "Peasants on the Move: State Peasant Resettlement in Imperial Russia, 1805-1830," Russian Review 52, 4 (1993): 472-85; Serguei I. Bruk, Vladimir M. Kabuzan, "Dinamika chislennosti i rasselenie russkogo etnosa, 1678-1917" ( The dynamics of figures and the establishment of Russian ethnical groups, 1678-1917), Sovetskaya istoriografiya 4 (1982): 9-25.

39. Moon, The Russian Peasantry, 20-21.

40. PSZ (I), vol. 8, n. 5633. On the various drafts of this these laws, see RGADA, fond 342, opis' 1, delo 37, part 2.

41. PSZ (I), vol. 12 n. $9332,9367$.

42. PSZ (I), vol. 15, n. 11490, vol. 16, n. 11638.

43. RGADA, fond 294, opis'1, dela 385,386; opis'2, dela 135, 145, 168.

44. PSZ, II, vol. 3, n. 2378; RGIA, f. 1149 (department zakonov gosudarstvennogo soveta) op. 2 , d. 44.

45. Isabel de Madariaga, Russia in the Age of Catherine the Great (London: Weidenfeld and Nicholson, 1981).

46. The High Chamber (Senate) records several such cases in 1816. Arkhiv gosudarstvennogo soveta, 5 vols. (Saint Petersburg, 1869-1904), vol. 4, vyp. 1, ch. 2:253-258.

47. TsGIAM, fond 54, opis. 1; RGADA, fond 615, opis' 1, several cases; RGADA, fond 342, opis' 1, dela 64, 119, 120.

48. Several cases in TsGIAM, fond 54, and in RGADA, fond 1209 (arkhiv prezhnykh votchnnykh del), in particular opis' 84. See also Michelle Lamarche Marrese, "The Enigma of Married Women's Control of Property in Eighteenth-century Russia," Russian Review 58, 3 (1999): 380-95.

49. The Senate still recorded a great number of these transactions in 1816. Arkbiv gosudarstvennogo soveta [Archives of the State Council], 5 vols. (Saint Petersburg ,1869-1904). Vol. 4 , vyp. 1, ch. 2: $253-258$.

50. PSZ (II), vol. 11, n. 9203.

51. PSZ (I), vol. 33, n. 26469.

52. RGIA, Fond 1149, opis' 2 , several dela.

53. Decrees of 1825, 1828, 1840, 1847. PSZ (I) vol. 40, n. 30407, psz II, vol. 3, n. 1696, vol. 15, n. 13051.

54. PSZ (II), vol. 11, n. 9203.

55. Otchet ministerstvo iustitsii za 1845 [Report of the Ministry of Justice, 1845] (Saint Petersburg, 1846), xix.

56. Svod zakonov, vol. 9, art. 546 (1833).

57. Wirtschafter, Structures of Society, 81.

58. The rapidly growing bibliography on this topic includes: Wirtschafter, Social Identity in Imperial Russia; and Virginia Martin, Law and Custom in the Steppe: The Kazakbs of the Middle Horde and Russian Colonialism in the Nineteenth Century (Richmond, Surrey: Routledge Curzon, 2001). Most of the available literature on legal action in Imperial Russia focuses on the post-1864 period: see Richard Wortman, Development of a Russian Legal Consciousness (Chicago: University of Chicago Press, 1976); William Wagner, Marriage, Property and Law in Late Imperial Russia (Oxford: Oxford University Press, 1994); Jane Burbank, Russian Peasants Go to Court: Legal Culture in the Countryside, 1905-1917 (Bloomington: Indiana University Press, 2004); Peter Solomon, ed., Reforming Justice in Russia, 1864-1994: Power, Culture, and the Limits of Legal Order (Armonk, NY: M. E. Sharpe, 1997); and Ekaterina A. Pravilova, Zakonnost' i prava lichnosti: administrativnaia iustitsiia v Rossii, vtoraia polovina XIX v.-oktiabr' 1917 [Legality and the rights of the person: administrative justice in Russia in the second half of the nineteenth century to October 1917] (Saint Petersburg: Izd-vo SZAGS, 2000). 
59. Robert E. Jones, The Emancipation of the Russian Nobility, 1762-1785 (Princeton: Princeton University Press, 1973); Daniel Saunders, Russia in the Age of Reaction and Reform, 1801-1881 (London and New York: Longman, 1992).

60. On this difference, see Vasilii I. Semevskii, Krest'ianskii vopros v Rossii v XVIII $i$ pervoi polovine XIX veka [The peasant question in Russia in the eighteenth to the first half of the nineteenth century), 2 vols. (Saint Petersburg: Obshchstevennaia pol'za, 1888); idem, Krest'iane $v$ tsarstvovanie Imperatritsy Ekateriny II [The peasantry under the reign of Catherine II], 2 vols. (Saint Petersburg: tipografiia F. S. Sushchinskago, 1901); Inna I. Ignatovich, Pomeshchich'i krest'iane nakanune osvobozhdeniia [Private landlords' peasants on the eve of emancipation], 2nd ed. (Moscow: tipografiia Sytina, 1910; 3rd ed., Leningrad, 1925).

61. Nikolai M. Druzhinin, Gosudarstvennye krest'iane i reforma P.D. Kiseleva [State peasants and the reform of P. D. Kiselev] (Moscow: Nauka, 1958).

62. Sbornik imperatorskogo russkogo istoricheskogo obshchestva [Collected essays of the Russian Historical Society], vol. X (Saint Petersburg, 1872), 285-88; de Madariaga, Russia in the Age : 139.

63. PSZ (I), vol. 27, n. 20620 (20 February 1803).

64. Steven Hoch and W. Augustine, "The Tax Censuses and the Decline of the Serf Population in Imperial Russia, 1833-1858," Slavic Review 38, 3 (1979): 403-25.

65. Serguei V. Mironenko, Samoderzhavie i reformy: politicheskaia bor'ba v Rossii v nachale $X I X v$. [Autocracy and reforms: political struggle in Russia in the early nineteenth century] (Moscow: Nauka,1989).

66. Druzhinin, Gosudarstvennye.

67. PSZ (II), vol. 17, n. 15462.

68. Hoch and Augustine, "The Tax Censuses," 410.

69. PSZ (II), vol. 16, n. 14669, 19 June 1841.

70. Nikolai Mel'nitskii, Sbornik svedenii o voenno-uchebnykh zavedeniiakh v Rossii [Collection of figures on the military establishments in Russia], 4 vols. (Saint Petersburg, 1857-1860), vol. 2, part 3: 187, 217; part 4: 52, 119; part 5: 141 .

71. Petr Keppen, Deviataia reviziia: issledovanie o chisle zhitelei v Rossii v 1851 goda [The ninth census: study of the number of inhabitants in Russia in 1851] (Saint Petersburg, 1857), 6-7, 21, 62, 88, 95, 100, 127, 142-44, 152-59.

72. Pavel'G. Ryndziunskii, "Vymiralo li krepostnoe krest'ianstvo pered reformoi 1861 g.?" [Were serfs really disappearing before the Reform of 1861?] Voprosy istorii 7 (1967): $54-70$.

73. Wirtschafter, Social Identity in Imperial Russia, 121.

74. Svod zakonov, vol. 9, art. 462-3 (1857); PSZ (II), vol. 11, n. 9203 (1836), vol. 14, n. $13012(1839)$.

75. Hoch and Augustine, "The Tax Censuses," 420.

76. Notarial archives in RGADA, fond 615, opis' 1 ; fond 1253 and 1274.

77. Keppen, Deviataia reviziia, 6, 7, 21, 88, 95-100, 127, 142-44, 152, 159.

78. Glavnyi General'nyi Shtab, Materialy dlia geografii i statistiki Rossii, sobrannye ofitserami general'nogo shtaba [Materials for the geography and statistics of Russia, collected by the officers of the General Headquarters], 25 vols. (Saint Petersburg, 1860-1868).

79. PSZ (II), vol. 11, n. 9203.

80. TsGIAM, fond 54 (Moskovskoe gubernskoe upravlenie), 1783-1917, opis' 1, for example $56,284,966,1509$. Several other cases can be found in Deistviia Nizhegorodskoi gubernskoi uchenoi arkhivnoi komissii, several booklets, 1890s.

81. RGIA, fond 1149 , opis' 2 , delo 90.

82. PSZ (II), vol. 20, n. 19283, vol. 22, n. 20825 ; RGIA, fond 1149, op. 3, delo 125.

83. RGIA, fond 1149 , opis' 2 , delo 20.

84. In particular, the law of 1847, in PSZ (II), vol. 22, n. 20825. 
85. Law of 1847, in PSZ II, vol. 22, n. 20825.

86. Michael Hittle, The Service City: State and Townsmen in Russia, 1600-1800 (Cambridge, MA: Harvard University Press, 1979); Pavel Ryndziunskii, Gorodskoe grazhdanstvo doreformennoi Rossii [Urban citizenship in pre-reform Russia] (Moscow: Nauka, 1958).

87. Boris Mironov, "The Economic Structure of Russian Towns in the Second Half of the Eighteenth and the First Half of the Nineteenth Centuries," Historical Social Research 16, 2 (1991): 128-43.

88. PSZ, 3, n. 1723; 4, n. 220, 1775, 1819.

89. SIRIO (Sbornik Imperatorskogo Rossiskogo istoricheskogo obshchestva) [Collection of the Imperial Historical Society] vols. 8, 93, 197, and 134; Wallace Daniel, "The Merchantry and the Problem of Social Order in the Russian State: Catherine II's Commission on Commerce," Slavonic and East European Review 55 (1977): 185-203; Wallace Daniel, "The Merchants' View of the Social Order in Russia as Revealed in the Town Nakazy from Moskovskaia Guberniia to Catherine's Legislative Commission," Canadian-American Slavic Studies 11 (1977): 503-22; Wallace Daniel, "Girgorii Teplov and the Conception of Order: the Commission on Commerce and the Role of Merchants in Russia," Canadian-American Slavic Studies, 16 (1982): 410-432.

90. On this, see Wirtschafter, Structures.

91. PSZ, I, vol. 8, n. 6215, vol. 10, nn. 7389, 7438, vol. 11, n. 8811, 8836.

92. TsGIAM, fond 32 opis' 1 and 2 contains extremely numerous cases on this topic.

93. Pavel G. Ryndziunskii, "Melkaia promyshlennost' (remeslo i melkotovarnoe proizvodstvo)" (The small side-activities-artisans and production-), in, Ocherki ekonomicheskoi istorii rossii pervoi poloviny XIX veka (Essays on the economic history of Russia during the first half of the nineteenth century), ed. Maria K. Rozhkova (Moscow: Nauka, 1959): 64-99.

94. Daniel Brower, "Urbanization and Autocracy: Russian Urban Development in the First Half of the Nineteenth Century," Russian Review, 42,4 (1983): 377-402.

95. Wirtschafter, Structures of Society, 86.

96. RGADA, fond 291, opis' 2 , several dela. On peasants of private estates involved in trade and their inscription on urban payrolls, see the documents in RGADA, fond 1287, opis' 3.

97. RGIA, fond 1287, opis' 39, delo 72 "Po revizii", 11. 39-40.

98. TsGIAM, fond 32, opis' l (1842-1866, glavnyi magistrat, with litigations between masters and workers); and opis' 2, 1823-1842. .

99. Kahan, The Plow, the Hammer, and the Knout, 343-45.

100. RGIA, fond 1287, opis' 39, delo 65.

101. Wirtschafter, Social Identity in Imperial Russia, 134.

102. Brower, "Urbanization and Autocracy," 393.

103. For Sheremetevs' the list is per names and years, with detailed activities of each peasant-trader or peasant-artisans entering a local guild, RGADA, fond 1287, opis' 3 , chast 2 , delol283 for the year 1835-36, delo 1298, for the year 1836-37 and delo 1391 for 1838.

104. See examples in RGADA, fond 291.

105. PSZ (I), vol. 39, n. 30115.

106. Wirtschafter, Structures of Society, 25.

107. RGADA, fond 291 (glavnyi magistrat), opis' 1, ch. 4, delo 18211.

108. On this see Manfred Hirdermeier, Bürgertum und Stadt in Russland, 1760-1860: Rechtliche Lage und soziale Struktur (Cologne, Böhlau, 1986); Manfred Hirdermeier, "Was war das mescantsvo? Zur rechtlichen und sozialen Verfassung des unteren städtischen Standes in Russland," Forschungen zur osteuropöschen Geschichte 36 (1985): 15-53.

Boris Mironov, "Russkii gorod vo vtoroi polovine XVIII-pervoi polovine XIXe veka: tipologicheskii analiz" [The Russian town during the second half of the eighteenth century to the first half of the nineteenth century: typological analysis], Istoriia SSSR 5 (1988): 150-168; Boris Mironov, Russkii gorod v 1740-1860 gody [The Russian town during the 
years 1740-1860] (Leningrad: Nauka: 1990); Evgenii V. Anisimov, Podatnaia reforma Petra I [The fiscal reform of Peter I] (Leningrad: Nauka 1982).

109. Seymour Drescher, Abolition: A History of Slavery and Antislavery (Cambridge: Cambridge University Press, 2009): 98.

110. Drescher, Capitalism and Antislavery.

111. Drescher, Abolition, 125-26.

This open access library edition is supported by Knowledge Unlatched. Not for resale. 
CHAPTER 5

\section{LABOR AND DEPENDENCE ON RusSian EsTATES}

\section{Introduction}

In Russia, landlords could ask peasants for quitrent or for labor services (corvées). Traditionally, Western, Russian, and Soviet historiography have all argued that quitrent encourages trade and economic growth but that labor service restricts both. ${ }^{1}$ This argument has been widely echoed by historians of serfdom in Western ${ }^{2}$ and Eastern Europe. ${ }^{3}$ Of course, many others disagree, maintaining that trade and economic growth can also take place under a system of corvée labor or even slavery in the strict sense. ${ }^{4}$

Any satisfactory answer to this question requires an assessment of labor productivity and the overall demesne efficiency: Some claim that corvées call for high supervision costs while simultaneously reducing labor productivity and peasants' interest in increasing productivity and market production. Others disagree, claiming that labor supervision is not necessarily stricter under corvées than under quitrent. Hoch, in particular, has shown that serf owners were able to exploit serf labor with minimum supervisory costs by harnessing the patriarchal authority structure of the peasant household. ${ }^{5}$

The question underlying this debate is important: were historical forms of forced labor compatible with the market, innovation, and capitalism? We may note that an increased dissemination of quitrent was recorded during the first half of the eighteenth century, followed by the greater success of labor services during the second half of this century, and that finally, in the first half of the nineteenth century, the quitrent regained its prominence, although to a lesser degree than previously. Within this overall framework, significant regional differences can be seen: forced labor was more widespread in the Black Earth region (the central, most 
fertile regions of European Russia), whereas the quitrent system was more widely practiced near industrial areas. ${ }^{6}$ Based on this observation, several historians have concluded that forced labor restricted trade and economic development. ${ }^{7}$

Yet this approach requires serious revision. Empirical analysis shows that the revival of labor services went along with an increasing integration of the demesne in proto-industrial activity, as well as in local and national markets for agriculture and manufactures. Overall trends since the eighteenth century provide evidence of an important link between rural estates and markets. Of course, regional variations were important, as we will see, and even beyond this, institutional constraints, social hierarchies, and market dynamics varied from one area to another and even from one estate to another. Most microeconomic studies focus on large estates ${ }^{8}$ even if some Soviet scholars like Koval'chenko exploited several estate archives. In part, such a focus creates a bias, as large estates were more inclined to adopt modern techniques and they tended to have higher yields and rates of commercialization than smaller units. Yet this bias does not invalidate our argument; rather, it confirms it. Despite the better performances of big estates, overall data reveal quite good outcomes for the Russian economy as compared with most Western economies, ${ }^{9}$ and this despite the well-known tendencies of statistics to underestimate products, yields, and revenues.

\section{Proto-industry, Trade, and Growth in the Eighteenth Century}

Proto-industrialization has long been considered an obstacle to modernization and industrialization - an approach that is firmly rooted in the hypothesis that large manufactures and the "British" way are the only paths to industrialization. More recently, this view has been strongly modified, stating instead that the Continental European, Asian, and Latin American paths, mostly anchored to small units, were the rule. ${ }^{10}$ Recent analyses have also shown that in contradiction to the first theories, guilds declined even without proto-industrialization (this was the case in most parts of England, Flanders, and the Netherlands). ${ }^{11}$ Conversely, in many other parts of Europe (Bohemia, northern Italy), the seigniorial institutions, community, ${ }^{12}$ and guilds remained strong despite the diffusion of proto-industry. ${ }^{13}$ But to what extent does Russian history confirm or invalidate these issues?

In eighteenth-century Russia, agricultural prices continued to climb, rising by a factor of two and a half, which no doubt made service labor more profitable than quitrent. ${ }^{14}$ At the same time, such profit was only 
possible if the estates were efficiently supervised. Supervisors were supposed to adopt good working methods; carry out an inventory of goods, land, and harvests; and keep the landowner informed about the running of the estate. Hence landowners also increased their interest in supervisors.

In this context, there is no evidence of an increasing autarchy of the demesne coupled with increasing wheat exports from "backward" Russia to the benefit of "advanced" Europe, as Wallerstein and Kula have argued. Exports undoubtedly rose, and, as Mironov has shown, Russian markets became progressively more integrated into the international and European markets. Nevertheless, the growth of exports did not take place at the expense of local and national markets; indeed, by 1760 the demand for grain in the heartland created a rise in grain prices. ${ }^{15}$ Russian local markets therefore became more integrated into a national market during the second half of the eighteenth century. ${ }^{16}$ The nobility's role in the expansion of rural trade is reflected in the fact that much of the rural expansion took place on the gentry's estates. In 1760, nobles' estates were the sites of 413 out of 1,143 rural fairs ( 36 percent), and by 1800 , they were the locations for 1,615 out of 3,180 (51 percent). This data clearly shows that not only landlords, but their peasants also, firmly entered the rural agrarian markets. Peasant activity in rural markets even surpassed that of merchants and small urban traders. ${ }^{17}$ Therefore, contrary to traditional arguments, trade in estate production increased with barshchina (corvées), which was compatible with exportation and long distances, as well as with the rise of local and national markets. ${ }^{18}$

Widespread local markets, therefore, became all the more important, not only for agriculture produce, but for proto-industrial products, as well. Since the mid-eighteenth century, peasants had been buying important shares of proto-industrial products while benefiting from increasing incomes. For example, the larger accessible labor market of peasants already familiar with linen-weaving gave Moscow and Ivanovo firms a greater competitive viability than the firms in Saint Petersburg. ${ }^{19}$ To control this market, noble landowners began retaking control of the sale of products from their estates and entering into urban trade circuits, with a certain degree of firmness. ${ }^{20}$ Proto-industry became ruralized. ${ }^{21}$ Between 1742 and 1801, the urban population dropped from 12 percent to 8 percent of the total population, ${ }^{22}$ and therefore industrial rural areas were sometimes differentiated and sometimes overlapped.

Thus while 5 percent of all private factories belonged to nobles in the 1720 s, the percentage rose to 20 percent by 1773 . In 1725,78 percent of industrial activity was located in cities; that dropped to 60 percent in $1775-78$ and to 58 percent, in $1803 .{ }^{23}$ On the whole, the second half of the eighteenth century saw a drastic increase in landlords entering 
the proto-industrial sector; the ruralization of proto-industry was not a symptom of demesne autarchy, but quite the contrary-it testified to the demesne's increasing commercialization. Both peasants and landlords entered the market in cereals, in addition to going in for proto-industrial activities and trade and transportation activities. Numerous "serf-entrepreneurs" registered businesses or even proto-industrial and industrial activities - sometimes on behalf of the landowner and sometimes quite independently ${ }^{24}$ - and they often employed workers in their proto-industrial activity. They came from the same villages or from neighboring districts. ${ }^{25}$ During and after the mid-eighteenth century, peasants bought an important share of proto-industrial products while benefiting from increasing incomes.

All these developments increased the need for labor and exacerbated competition for goods and proto-industrial labor markets. Competition therefore rose not only between nobles and merchants, but also among nobles; even more than in the first half of the eighteenth century, landlords competed with one another to keep the best master-peasants, who trained other artisans. Litigations on runaways and estate records confirm this picture. As a consequence, many estate owners sought to keep their peasant-workers on the estate instead of sending them to town. ${ }^{26}$ As in the case of the sale of products, it would be reductive to see the landowners' orientation toward factories merely as a desire for estate autarchy and market closing and hence as a regression of the Russian economy. In reality, what the landowners wanted was to take over the proto-industrial and manufacturing sector, once dominated by peasants and merchants. This accounts for their request, which Catherine granted, to prohibit any form of serfdom in factories owned by non-nobles. ${ }^{27}$ Estate archives show that landlords had every interest in developing a sort of "protectionist" politics beneficial to the estate's peasants and craftsmen. ${ }^{28}$ For example, Count Sheremetev did not hesitate to publish an instruktsiia giving priority to local peasant-traders over urban merchants in the commercialization of the Pavlovo estate's products. ${ }^{29}$ Peasant-masters also demanded from Count Sheremetev the exclusive right to sell their products in Nizhegorod. ${ }^{30}$ Sheremetev's estate-law court regulated conflicts between peasants and merchants, and the decisions were often favorable to the former. ${ }^{31}$ In other words, peasants and landlords made arrangements to shape markets and competition rules to their own advantage and to exclude urban merchants and producers.

Labor relations were therefore extremely complex. In the NizhnyiNovgorod province (250 miles east of Moscow), on the Demidov estate in particular, there was a mix of both compelled and hired labor. The latter was used for some processing of products and for the supervisory 
personnel in the mills and brickworks, and compelled labor was used to mill rye and wheat and for cottage industry, including spinning yarn and making linen cloth. ${ }^{32}$ The relations of dependence between peasants, merchants, and manufacturers should be understood in this context. One of the key factors was the control of raw materials. As long as every stage in the production process took place within the peasant household, the producer remained more or less an independent craftsman. The fact that flax cultivation was so widespread outside the Black Soil provinces helped make linen production especially resistant to change. But in sectors like cotton and silk weaving, where the cottage weavers depended on outside sources for their materials, wage relations grew more rapidly. ${ }^{33}$ For the supply of raw materials for metalworking, the development of production in the Urals region modified the networks and the hierarchies. This was true in particular after the 1760s, when the Demidov estate in the Urals region exported raw materials for metallurgy to the proto-industrial districts of Tula, Nizhnyi-Novgorod, and Moscow. ${ }^{34}$

Peasants could buy materials themselves, but sometimes landlords provided raw materials and made advances to their peasant-master. In such cases, too, after the end of the eighteenth century, landlords developed a clear strategy to enter and control networks that had been previously dominated by traders and merchants. It is interesting that nobles adopted the same strategies as merchants to control the output system (i.e., advancing money and/or raw materials). ${ }^{35}$ Again, this confirms that legal limitations on mobility alone did not suffice; otherwise estate owners would have not developed this system of advances to keep peasant-workers bound to them.

To sum up, the rebirth of barshchina (corvées) during the second half of the eighteenth century was accompanied neither by an increased exploitation of peasants solely with a view to export trade nor by a crisis in manufacturing business and markets in general, as predicted by Witold Kula's model. The demesne economy and the Russian economy as a whole were more efficient, flexible, and market oriented than he stated. Agriculture and proto-industrial markets developed intensively, and so did national income and per-capita income. Agriculture and proto-industry expanded, and the competition between noble landowners and merchants was institutional before it became economic. The former wanted to enter into trade and industry at the expense of the latter-and succeeded, thanks to the support of institutional measures such as the exclusion of serfs from factories managed by merchants. Thus labor services raised commercial produce, and proto-industrial activity became strongly integrated into the demesne activity. 
At the same time, these multiple activities increased competition for labor time between estate owners and peasants, nobles and merchants, and even within the peasant family. Institutions (state law, demesne law, and peasant commune law) provided a set of rules to solve this problem. These arrangements were not without conflicts, but, as a whole, rural institutions worked well enough to ensure coordination. The decreasing impact of bad harvests on the standard of living and the increasing integration of the peasantry and the landlords into market networks testify to this increasing coordination among the involved actors. Evidence suggests that the output of both agricultural produce and proto-industrial products increased throughout the eighteenth and nineteenth centuries; in turn, this sustained the demand for manufactured goods, which was mostly satisfied by local proto-industrial activity that utilized labor-intensive technology. ${ }^{36}$

The growth in productivity and the standard of living, as well as and the commercialization of agriculture in Russia, can hardly be explained by the potentialities (i.e., the possibility of extorting more and more surplus by force) of a system of serfdom, which did not exist as such, at least not in its pure form, but rather can be explained by the flexibility of a world made up of inducements and constraints, central law, and local customs. Thus the coexistence of service labor and quitrent enabled the peasant economy and that of the noble landowners to cope with the fluctuations of the economy by limiting their impact on the level of activity, standard of living, and investments.

\section{From Peasant-masters to Peasant-workers? (1800-1861)}

The first half of the nineteenth century has usually been described as the time of the deepening "crisis of serfdom" in terms of income growth, demographic trend, and social unrest. The rate of growth is said to have slackened during this period, the net increase of population is estimated to have decreased as well, while social unrest in the countryside and industrial areas is understood to have resulted from the growing tensions in Russian society at the time. During the past two decades, these views have been seriously challenged. Economic historians have revised the rate of growth in agriculture and industry upward, as well as overall economic activity, ${ }^{37}$ and historical demography has corrected the increase of population-i.e., the rate of mortality sank and children's exposure to disease also fell. ${ }^{38}$ The evolution in legal and institutional settings, in particular the transfer of private peasants into other categories that we have examined in previous chapters, is also part of this broader dynamic 
and offers a far less static picture-one that changed again during the first half of the nineteenth century, when price fluctuations were more pronounced than during the second half of the eighteenth century, and this led again, as during the first half of the previous century, to mixing corvées and quitrent. ${ }^{39}$

At the same time, noble estates were concentrated; the number of small estates declined, while large properties became the rule to such an extent that in 1857 , noble estates with less than 21 peasants accounted for barely 3.2 percent of all estates; those with between 21 and 100 peasants made up 15.9 percent; and the great majority of estates had between 100 and 500 peasants ( 37.2 percent), 500 and 1,000 peasants ( 14.9 percent), or even more than 1,000 peasants ( 28.7 percent). ${ }^{40}$ This trend was linked to the increasing indebtedness of the estate owners and the limited capital markets available to them; the growing institutional pressure of a tsarist state favoring peasants' emancipation and merchants' development also contributed to the concentration of estates.

Quitrent declined on state estates and on some private estates as well, while rising in the heartland (although this rise was generally moderate). Regional specialization also increased, with central and other industrial and proto-industrial areas tending to specialize while agricultural areas lost nonagrarian activities. In particular, while factories shut down and proto-industrial activity was reduced in steppe and central Black Earth areas, ${ }^{41}$ the surface area of cultivated land expanded in the territory as a whole and inside the main estates. ${ }^{42}$ This process was accompanied by the reorganization of barshchina on a new basis. Urochnaia sistema (service labor by task) came into wide use in different forms; one activity was assigned per day, or each work group was assigned to a particular part of the nobleman's estate and completed a full work cycle. ${ }^{43}$ This solution enabled the expansion of the seigniorial reserve, as well as the intensification of peasant labor. ${ }^{44}$ It was adopted in strictly agricultural areas as in areas close to industries. This process corresponded to an increase in agricultural production and, most important, to a growth in marketed production and market integration. During the first half of the nineteenth century, grain prices in Russia showed a clear tendency toward homogenization and correlation on the national level. ${ }^{45}$

In the central industrial regions, the main difference from the previous century was that noble landowners no longer restricted peasant movements between the city and country. This was for reasons of choice and constraint-in part, more volatile prices led some landlords to diversify their economic strategies; and in part, industrial and tsarist elites pushed for increasing liberalization of the labor market. During 
the 1830s, '40s, and '50s, at the urging of the Moscow Section of the Manufacturing Council (Moskovskoe otdelenie Manufakturnogo Soveta, a corporate association of central-region industrialists), the imperial government approved a series of decrees that standardized the procedures for issuing and extending passports and tickets for peasant-migrants. On 24 May 1835, the government issued a new law that denied the right of landowners and local authorities to recall employed peasants from factories until the expiration date of their passports or of their permission for temporary leave. Initially the law was limited to the Moscow and Saint Petersburg districts, but by the early 1840s it had been extended to most industrial provinces.

The main issue was that the use of obrok and the movements of peasants in the city and in neighboring estates had intensified. ${ }^{46}$ During the $1840 \mathrm{~s}$, in the northwestern and western agricultural and industrial regions of European Russia, passports and tickets granted to peasants concerned between 25 and 32 percent of the male population. ${ }^{47}$ By 1850, in the Vladimir province, 92.44 percent of the state peasants were involved at least part-time in a nonagricultural occupation; in Moscow province, the proportion was 89 percent; in Kostroma province, 86.5 percent; in Novgorod province, 80.5 percent; in Pskov province, 80 percent; in Iaroslavl province, 75.8 percent; and in Nizhnyi-Novgorod, 65.7 percent. ${ }^{48}$

This trend contributed to a remodeling of social relations. Unlike in the previous period and despite legal interdictions, noble landlords now often rented out peasants and craftsmen to non-noble merchants and industrialists. ${ }^{49}$ In rural and proto-industrial areas that were close to industrial districts, social differentiation was more important between peasants, but as a whole they benefited from higher incomes per capita than in agricultural regions. Their diversified economies provided protection against both crop failure and market downturns. In these areas, the way back to proto-industry from countryside to town was not synonymous with a decline of the putting-out system (i.e., subcontracting while supplying raw materials). In 1828, 6,300 weavers worked in factories in the greater Ivanovo region (which included large swaths of both Vladimir and Kostroma provinces), while 18,224 (74 percent) worked outside of factories. In 1849, the number of factory weavers had doubled to 14,854 ; the number of nonfactory weavers had tripled, however, to 56,980 (79 percent). ${ }^{50}$ With a flexible network of knowledgeable peasant weavers, cotton-printing firms had little incentive to expend capital on centralized weaving establishments; in general, only high-end grades of cloth were factory-produced. In Vladimir province, in the early 1850s, 18,000 factory looms merely supplemented the 80,000 peasant looms 
filling factory orders. ${ }^{51}$ Most Russian weaving was performed in peasant homes throughout the central industrial region, either as an independent kustar' (craftsmen) activity, on commission from printing factories, or on commission from independent middlemen who distributed yarn and then sold the finished cloth to printing factories.

Peasant-masters increasingly employed wage earners, often for short periods of time during which workers were under the strong legal and social control of the masters. Conflicts between peasant-masters and their workers increased; in such cases petitions were sent to local landlords, who were supposed to intervene in defense of the peasant-workers, which they often did. ${ }^{52}$ Conflicts concerned issues such as wages and the possibility of moving. If in certain cases the landlords and commune elders were favorably disposed toward temporary migration, in other cases they opposed it. For example, from a budget study of a large estate in Orlov, in the Black Earth region, we learn that in the last decade before emancipation, despite the obvious preference for benefits to be derived from quitrent labor, the administrators of the estate forced quitrent peasants to also perform service labor in peak seasons. During the harvest they were required to work on the demesne fields and transport grain to the market, among other tasks. ${ }^{53}$ The regulation of competition concerned the distribution of peasant time as well. In Pavlovo, the Sheremetevs tried to achieve a double goal: to develop proto-industry without abandoning agriculture. In this regard, once again, there was a convergence of interest between certain peasants and their communes and the Sheremetevs. In 1802, P. B. Sheremetev received a petition from some local peasants, asking him to intercede for on their behalf with their masters so that they might go and take in the harvest. ${ }^{54}$ Sheremetev thus issued an $u k a z$ regulating the renting of land (limiting it to peasants in proto-industry) and limiting proto-industrial activity as well. ${ }^{55}$

Taxes also contributed to sharp conflicts. The commune's leaders and the landlords worried about the size and yield of the urban activities. Migration meant increased economic burdens on the remaining households. ${ }^{56}$ Tensions within the village were often resolved by appealing to the landlord. This was especially true in rural areas far enough away from proto-industrial and industrial areas. As Steven Hoch has persuasively demonstrated, peasant migration had to be negotiated within the family, between the family and the village assembly, and between the village and the landlord. Households and landlords sought the same goal: to assure a high and constant labor capacity during the peak season, which meant recalling emigrants and, on this basis, sharing them between the peasants and the landlord's arable land. This system was based upon short-term 
intensive labor and strong seasonal differences in the intensity applied to agricultural labor.

Conversely, peasants were sometimes forced by their village commune to work in the factory to pay off their debts; at other times, they entered freely into the agreement for the same purpose. As the putting-out system grew through the early 1800s, many independent domestic weavers found themselves increasingly tied to particular factories or particular putting-out middlemen, because they had accepted loans or advances to buy yarn or more advanced looms. A law of 1835 stipulated that the employment of all workers be based on a personal contract between employer and employee that specified the responsibilities of both sides. Since most workers were peasants whose period of residence in the city was determined by their passports, the period of the contract's validity was usually limited by the term of the passport. Workers were not supposed to leave their places of work until expiration of their contracts. This regulation, however, was difficult to enforce. Many entrepreneurs and managers complained that workers left their enterprises for the countryside or better employment opportunities before their contracts had expired. ${ }^{57}$ Yet all this was a symptom of economic and social dynamics, not of stagnation. Peasant families, landlords, merchants, entrepreneurs, and official institutions competed on the labor market to keep not only skilled workers and artisans, but also simple servants and laborers. The increasing demand for foodstuffs, services, and manufactured items was at the root of all this. Limitations placed on labor mobility were therefore not the symptom of a preindustrial society and backward economy, but just the opposite-they were evidence of its dynamism. As a whole, the Russian agrarian market developed further during the first half of the nineteenth century, and the convergence of prices testifies to the formation of a real national market. At the same time, regional specialization progressed: central and eastern agricultural areas increased productivity and marketable production, while proto-industrial areas created a denser network of urban towns and intensified product specialization. Both the putting-out system and urban manufacture were widespread, sometimes coexisting in the same area but more often developing separately in different areas and for different products. However, there is no evidence that in the long term one single solution prevailed over the other, or that one was more efficient than the other. Russian growth took place on the basis of the coexistence of these different organizations and on the basis of a long-term trend in which proto-industry and manufacture units moved from the town to the countryside and vice versa. Not only were the merchants urban, but landlords and even peasants, too. 


\section{Toward a Reassessment of Second Serfdom in Eastern Europe}

These outcomes confirm similar recent issues in the study of Eastern European agriculture under serfdom. ${ }^{58}$ For example, in Brandenburg-Prussia, by the turn of the nineteenth century, commutation payment increasingly eclipsed labor services. As in Russia, the government encouraged changes in the legal status of peasants ${ }^{59}$ however, before that date, increasing labor service in the seventeenth and late eighteenth centuries was not synonymous with a retreat from the market, as previously stated in the historiography, but, quite the opposite, commercialization of both peasant and demesne production (agriculture and proto-industrial products) quickly increased. ${ }^{60}$ In contradiction to traditional historical literature on these matters (which conveyed the impression that East-Elbian agriculture was a simple affair of cereal monoculture based on coerced labor), new detailed analyses based upon estates' archives reveal a complex picture of a large and expansive workforce and high commodity sales. This was true not only of Brandenburg, but also of other regions of east-central Europe, including Poland. Peasant labor services here provided only 40 to 50 percent of the demesne labor force required during the summer months and thus had to be supplemented by hired labor. ${ }^{61}$ In all these areas, both peasants and seigniors employed hired labor. ${ }^{62}$ There were also migrant day laborers who worked only during the harvest. In eastern Prussia, many of the day laborers lived in small towns, subsisting on wages earned during the peak season. Tracy Dennison and Sheilagh Ogilvie have recently stressed the strong similarities between Russia and Bohemia regarding serfdom and social relations. Peasant and seigniorial institutions interacted in both systems and strongly contributed to the social and economic dynamics. ${ }^{63}$

Taken together, the experiences of Russia, Prussia, Lithuania, and some parts of Poland lead to the conclusion that on the whole, "second serfdom" was not so much a form of slavery but, above all, a set of legal constraints on labor mobility. These rules were dictated much less by a scarcity of population than by increasing demand for agriculture produce and proto-industrial products, encouraging a Smithian growth. Labor and other institutions (seigniorial estate and justice, communes, and guilds) were flexible enough to simultaneously guarantee a stable set of rules and the procedures to adapt them to the changing economic and social environment. Labor services were not opposed to market development; quite the contrary, the two enhanced each other. Proto-industry developed, and the specialization of some areas went along with the 
seasonality of proto-industrial activity for many peasants. Estate relations sometimes opposed proto-industry but in some other cases were favorable to it, which did not necessarily enhance or retard the proletarization of peasants and craftsmen (as asserted in Franklin Mendel's model in which proto-industrialization slowed the growth of towns, confirmed by Jan De Vries).$^{64}$ Instead, agrarian development, proto-industry, demographic insights, and institutional and legal hierarchies varied from one estate to another, within the same country, in accordance with the specific relations among the landlord, the peasant community, and the involved markets. Still, despite this extreme variety, it is difficult to maintain that bondage and legal constraints on labor mobility were opposed to market and proto-industrial development and that developing markets in the West was the origin of increasing bondage in the East. Indeed, existing studies provide the following picture: Most microeconomic studies concern large estates with better-preserved archives. Certainly, on these estates the conditions of serfs were better; productivity was higher; and integration in the market was more developed than in smaller units. Also, all these indicators were more marked in industrial and proto-industrial areas than in agricultural regions. Yet when one takes all the statistics available since the first half of the nineteenth century, even if the average values seem lower than on the big estates, the overall picture is not as dark as earlier commentators argued. First, because we know now that overall statistics underestimate peasant and landlord production: based upon interviews with producers or with indirect evidence, figures suffered from the producers' incentive to hide part of their production and income for fiscal reasons ${ }^{65}$ Statisticians were also concerned with the "poverty of the peasantry" and exaggerated losses and crises. ${ }^{66}$ Now, even if we do not correct the data, the final picture shows increasing productivity, well-being, and commercialization, from the eighteenth century on. Between 1718 and 1788, the Russian aggregate national income increased fivefold, raising per capita income 85 percent. After 1788, the annexation of rich southern provinces still increased this growth ${ }^{67}$.

These new estimations require us to revise the conventional views; the most pessimistic recent analyses show that even if Russia's main economic indicators were persistently below those of main Western European countries, the gap between them was not that important and did not widen until collectivization. Before that date, the gap was constant or even sometimes narrowed, in terms of yields and commercialization in periods such as the second half of the nineteenth century. ${ }^{68}$ Other, more optimistic, recent interpretations even conclude that by 1788 , the average Russian was as rich as his English equivalent and only 15 percent poorer than the average Frenchman, who at that time enjoyed the 
peak of his fortunes in the eighteenth century. During the period of the Revolutionary and Napoleonic Wars, moreover, the Russian maintained his position, surpassing the Frenchman and rising with the Briton to the very top of the international league table. ${ }^{69}$ This means that unlike the conventional images of historiography, Russian economic growth was far from negligible.

This trend finds a confirmation in the rate of growth of the population. Recent analyses had sought to take into account the overall underestimation of birthrates in eighteenth- and nineteenth-century censuses, as well as the annexation of new territories and the resettlement (legal and illegal) of the peasantry. Once these biases had been corrected, then the natural rate of population growth is considerable: on peasant estates, it was at about 0.70 percent, between 1678 and 1719; 0.62 percent, between 1719 and 1744; 0.97 percent, between 1744 and 1762; and 0.96 percent during the next twenty years. It fell to 0.60 , between 1782 and 1795, rose again to 0.86 , between 1795 and 1811, but collapsed during the Napoleonic Wars to -0.42 percent. During the first half of the nineteenth century, the natural rate of growth of Russia's peasant population increased again to 0.94 , in $1815-33$; to 0.59 , between 1833 and 1850; and to 0.54 percent, between 1850 and $1857 . .^{70}$ Certainly, the high birthrate corresponded to an equally high rate of death, in particular among children. This trend has usually been considered evidence of the backwardness of Russia and its poverty. However, in recent years, this view has been seriously challenged: high child mortality actually had less to do with famine than with diseases linked to lack of hygiene (in regards to water in particular), epidemics, and wars. ${ }^{71}$

How can these new estimations on income, productivity, and demographic rates be explained?

Answers have put the accent either on legal constraints (forced labor) or, just the opposite, on flexibility. In the first variant, growth has been linked to the profitability of serfdom; this is a revisionist approach that attributes the peasants a status close to that of slaves. According to this view, bondage and slavery are much more profitable than some liberal authors asserted and are perfectly compatible with economic growth, markets, and capitalism. However, the previous chapters provide evidence of the second interpretation: economic growth was linked to flexible and increasingly relaxing legal constraints. In Russia, there were no official rules mentioning corvées before they were limited in the 1770s. Existing rules imposing limitations to peasants' movements were produced and implemented at the intersection of state, seigniorial, and village institutions. Unlike Brenner, I do not see these rules as the expression solely of the strength of the nobility over the peasantry, for they required the 
interaction between the rules of the nation, estates, and villages. The real functioning of serfdom was founded upon these multiple institutions, actors, and rules. There were no classes in the Marxist sense, but rather porous estates. Russian peasants were not "serfs de la glebe" but strongly dependent people with extremely limited legal rights. These rights, however, increased over time. Serfs were not chattel slaves like American slaves. They always signed a contract with the landlord, and their progressive emancipation occurred before the general abolition of serfdom in 1861. This is why labor services and strong legal constraints on labor mobility were not opposed to market development. Landlords and the demesne economy were not devoted to unproductive tasks and supporting monopolistic and parasitic attitudes, but instead sought to exploit imperfect competition to increase their profits. The peasant economy under serfdom corresponded neither to the Chayanovian model of a peasant looking to satisfy his family's needs and entering the market only when obliged, nor to Kula's model of peasants pushed to produce by the landlord, who took the entire product and sold it on the market. Peasants were already integrated into market activity, and proto-industry was not necessarily residual (that is, an activity engaged in only after time and opportunities in agriculture had been fully exploited). Peasants' and nobles' integration into the market does not confirm the link between labor service and poor market development. Anti-economic cultural values are used to oppose imaginary peasantries to proletarians, landlords to capitalists. In reality, Russian landlords were interested in profits, and peasants were integrated into markets to various degrees. That they did not transform in accordance with a Western model does not mean that they were backward, but only that historical transformations of markets and societies may take different forms.

These issues do not close the dossier but raise new questions. If second serfdom was a much more flexible world than is usually held, if social groups evolved and the economy showed a high rate of growth, then where is the boundary between second serfdom and free labor and capitalism? This set of questions constitutes an effort to escape explanations of non-European realities in terms of missing factors (missing in relationship to a mythical, stylized West). Free labor, private property, industrialization, and urbanization are some of the most recurrent features of this mythical West. We consider Russian history a confirmation of the existence and viability of different paths of development and as a heuristic aid to questioning the imaginary West and an occasionally imaginary Asia. Rather than looking for missing factors to explain Russian backwardness, we want to reevaluate the rules and the practices of labor in some Western countries on the basis of the Russian case. More generally, once we have 
called into question the existence of second serfdom and, therefore, questioned an ideal type of economic and social system and an equally ideal type of capitalism, we need to progress further in this direction and ask whether free labor is an appropriate category with which to understand market economies.

\section{Notes}

1. Gerschenkron, Economic Backwardness; Crisp, Studies in the Russian.

2. Bonnassie, From Slavery to Feudalism; Duby, Les trois ordres; Scott, The Peasantries of Europe.

3. Brenner, "Agrarian Class Structure, 30-74; Aston and Philpin, The Brenner Debate.

4. Blanchard, Russia's Age of Silver; Dennison, Institutional Framework.

5. Hoch, Serfdom and Social Control.

6. Semevskii, Krest'ianskii vopros; idem, Krest'iane; Koval'chenko, Russkoe krepostnoe.

7. Koval'chenko, Russkoe krepostnoe.

8. Dennison, The Institutional Framework; Peter Czap, "The Perennial Multiple-family Household," 5-26.

9. Carol Leonard, Agrarian Reforms in Russia (Cambridge: Cambridge University Press, 2011).

10. For a synthesis and a discussion, see Sheilagh Ogilvie, Markus Cerman, eds., European Proto-industrialization (Cambridge, Cambridge University Press, 1996); Pierre Jeannin, "La proto-industrialization: développement ou impasse?" Annales ESC 35 (1980): 52-65.

11. De Vries, The Industrious Revolution.

12. Oglivie, "The Economic World of the Bohemian Serf," 430-53; Belfanti, "Rural Manufactures," 253-80.

13. Sheilagh Ogilvie, "Guild, Efficiency, and Social Capital," Economic History Review LVII (2004): 286-333; Carlo Poni, "Per la storia del distretto serico di Bologna, secoli XVIXIX," Quaderni storici 73 (1990): 93-167; Gérard Gayot, De la pluralité des mondes industriels. La manufacture royale des draps de Sedan, 1646-1870 (Paris: EHESS, 1995).

14. Boris Mironov, The Social History of the Russian Empire, 2 vols. (Boulder, CO: Westview 1999).

15. Ibid.

16. Boris Mironov and Carol S. Leonard, "In Search of the Hidden Information: Some Issues in the Socio-Economic History of Russia in the Eighteenth and Nineteenth Centuries," Social Science History 9 (Autumn 1985): 339-59; Mironov, Vnytrennii rynok.

17. Mironov, Vnutrennyi rynok, 153-54.

18. Koval'chenko, Russkoe.

19. Klaus Gestwa, Proto-industrialisierung in Russland (Göttingen: Vandenhoeck and Ruprecht 1999); Ksenia N. Serbina, Krest'ianskaia zhelezodelatel'naia promyshlennost' tsentral'noi Rossii XVI-pervoi poloviny XIXe vekoi [The peasant metallurgic home industry in Central Russia from the Sixteenth to the first half of the Nineteenth century) (Leningrad: Nauka, 1978). For the Demydov estate in Tula see RGADA, fond 271, delo 1061.

20. Tatiana F. Izmes'eva, Rossiia p sisteme evropeiskogo rynka. Konets XIXe-nachalo XX $v$. [Russia in the system of the European market, end of the nineteenth to the early twentieth century] (Moscow: Nauka, 1991).

21. Sergei Strumilin, Ocherki ekonomicheskoi istorii Rossii i SSSR [Studies in the economic history of Russia and the USSR] (Moscow: Nauka, 1966), 330-33; RGADA, fond 199 (G. F. Miller); Emilia I. Indova, "O rossiskikh manufakturakh vtoroi poloviny XVIII v." [On 
the Russian manufactures during the second half of the eighteenth century], Istoricheskaia geografiia Rossii: XIX-nachalo XX v. (Moscow: Nauka 1975), 248-345; Emilia I. Indova, Dvortsovoe khoziaistvo v Rossii [The palace economy in Russia] (Moscow: Nauka 1964).

22. Boris Mironov, "Consequences of the Price Revolution in Eighteenth-century Russia," The Economic History Review 45 (1992): 457-78.

23. Mironov, "Consequences," 465.

24. On serfs-entrepreneurs, see Robert Rudolph, "Agricultural Structure and Proto-industrialization in Russia: Economic Development with Unfree Labor," The Journal of Economic History 45 (1985): 47-69; Prokof'eva, Krest'ianskaia obshchina; Iurii A. Tikhonov, Pomeshchic'i krest'iane v rossii: feodal'naia renta v XVII-nachale XVIII $v$ [The private estates' peasants in Russia: the feudal rent in the seventeenth to early eighteenth century] (Moscow: Nauka, 1974). On the urban activity of private peasants, I have consulted the following archives: RGADA, fond 294, opis' 2 and 3; fond 1287, opis' 3. TsGIAM, opis' 2, dela 31, 40, 82, 124, 146; RGADA, fond 210: razriadnyi prikaz; fond 248, Senat I senatskie uchrezhdeniia; fond 350: revizkie skazki po nizhegorodskoi gubernii, opis' 2, dela 1975 and 2056; fonds 615, krepostnye knigi, dela 526, 528, 529, 4753, 6654; fond 1209 (pomestnyi prikaz), opis' 1, delo 292; fond 1287 (Sheremetev), opis' 5 and 6; RGIA, fond 1088 (Sheremetev, opis' 3, 5, 10). See also Gestwa, Protoindustrialisierung.

25. Serbina, Krestianskaia, 37.

26. Dennison, "Did Serfdom Matter?"

27. Melton, "Proto-industrialization," 73-81.

28. RGIA, fond 1088, opis' 10, dela 616 and 618 .

29. Ibid.

30. RGIA, fond 1088, opis' 10, delo 611.

31. Sheremetev published instruktsiia in 1802 and 1832. RGIA, fond 1088, opis' 10, delo 607.

32. Rudolph, "Agricultural Structure," 47-69.

33. Melton, "Enlightened Seignoralism," 675-708.

34. Serbina, Krestianaskaia, 100-101; Gestwa, Protoindustrialisierung.

35. RGIA, fond 1088, opis' 10, delo 524. On this, see also Boris N. Kashin, Kres'ianskaia promyshlennost' [The peasant rural industry], 2 vols. (Moscow and Leningrad, 1935), Vol. I: $215,347-49$.

36. Melton, "Proto-industrialization," 73-81; Evsey Domar and Michael Machina, "On the Profitability of Russian Serfdom," The Journal of Economic History 44 (1984): 919-55.

37. Paul Gregory, Russian National Income (1885-1913) (Cambridge: Cambridge University Press, 2004).

38. Hoch, Serfdom and Social Control.

39. RGADA, fond 1252, opis' 1 :Abamelek-Lazarevy's estate, province of Tula; fond 1282, Tolstye-Kristi's estate, province of Riazan; fond 1262, opis' 1, Prince Gagarin's estates in Saratov and Tambov provinces; fond 1287, Sheremetev's estate.

40. Aleksandr' Troinitskii, Krepostnoe naselenie v Rossii po 10 narodnoi perepisi (The Russian serf population according to the tenth census) (Saint Petersburg: Wulf) 1861: 45.

41. Irina V. Ledovskaia, "Biudzhet russkogo pomeshchika v 40-60kh godakh XIX v" (Estate owners' budgets in the 1840s-'60s), in Akademiia Nauk SSSR, Materialy po istorii sel'skogo khoziaistva $i$ krest'ianstva SSSR, vol. 8, (Moscow: Nauka 1974): 240-245. David Moon, The Russian Peasantry, 1600-1930: The World the Peasants Made (London and New York: Addison Wesley Longman, 1999).

42. Ibid.

43. Gagarin's estate in: RGADA, fond 1262, opis' 20/4; delo 30.

44. Koval'chenko, Krepostnoe: 275. 
45. Mironov and Leonard, "In Search of the Hidden Information," 339-59; Ivan D. Koval'nchenko, L.V. Milov, Vserossiskii agrarnyi rynok XVIII-nachala XXv. [The all-Russian agrarian market, eighteenth century to the early twentieth century] (Moscow: Nauka, 1974).

46. Koval'chenko, Krepost'noe: 394; Boris Gorshkov, "Serfs on the Move: Peasant Seasonal Migration in Pre-reform Russia, 1800-1860," Kritika: Explorations in Russian history 1, 4 (2000): 627-56.

47. Nikolai M. Druzhinin, Gosudarstvennye krest'iane i reforma P.D. Kiseleva [The state peasants and the reforms of Kiselev] (Moscow: AN SSSR), 2: 315, 321.

48. Druzhinin, Gosudarstvennye krest'iane, 2: 296-390.

49. RGADA, fond 342, opis' 3, delo 749. Aussi: RGADA, fond 1287 (Sheremetev), opis' 3, chast' 1, delo 107, 117, 1745 .

50. Dave Pretty, Neither Peasant nor Proletarian: The Workers of the Ivanovo-Voznesensk Region, 1885-1905, Ph.D. diss., Brown University, 1997.

51. Olga Crisp, "Labor and Industrialization in Russia," in The Cambridge Economic History of Europe, vol. 7, pt. 2, ed. Peter Mathias and Michael Postan (Cambridge: Cambridge University Press 1978), 308-415.

52. For the Sheremetevs' estates in Pavlovo and Vors'mo: TsGIA fond 1088; opis' 3, delo 626, $974,440,370,417$.

53. Ledovskaia, "Biudzhet."

54. Quoted in Kashin, Kres'ianskaia Promyshlennost, 228-9.

55. RGIA, fond 1088, opis' 10 delo 642. (ukaz 11 Sept. 1802).

56. Hoch, Serfdom and Social Control.

57. RGIA fond 18, opis' 2, delo 1927, 11. 1, 3, 212-13; TsGIAM fond 14, opis' 1, delo 3266, 11. 2-38 and TsIAM, fond 2354, opis' 1, delo 41, 1l. 197a-99, 228.

58. For a deep revision of second serfdom in Central and Eastern Europe, see Markus Cerman, "Social Structure and Land Markets in Late Medieval Central and Eastern Europe," Continuity and Change 23, 1 (2008): 55-100.

59. Hartmut Harnisch, "Bäuerliche Ökonomie und Mentalität unter den Bedingungen der ostelbischen Gutsherrschaft in den letzten Jahrzehnten vor Beginn der Agrarreformen," Jahrbuch für Wirtschaftsgeschichte 24 (1989): 87-108.

60. Hagen, Ordinary Prussians.

61. Robert Frost, "The Nobility of Poland-Lithuania, 1569-1795," in The European Nobilities in the Seventeenth and Eighteenth Centuries, vol. II: Northern, Central and Eastern Europe, ed. Hamish Scott (London: Routledge 1994).

62. Melton, "Population Structure."

63. Dennison and Ogilvie, "Serfdom and Social Capital," 513-44.

64. Jan De Vries, European Urbanization, 1500-1800 (London: Meuthen, 1984).

65. Alessandro Stanziani, "Les statistiques des récoltes en Russie, 1905-1928," Histoire et mesure VII, 1/2 (1992): 73-98.

66. Alessandro Stanziani, "Les enquêtes orales en Russie, 1861-1914," Annales ESC 1 (2000): 219-241.

67. For a full discussion of these materials, see Blanchard, Russia's Age of Silver, chapter 5 and appendix 2, revised in Ian Blanchard, "Le développement économique en perspective historique: l'avenir de la Russie à la lumière de son évolution à l'époque moderne (17001914)" in Les entreprises et leurs réseaux: hommes, capitaux, techniques et pouvoirs XIXe-XXe siècles. Mèlanges en l'honneur de François Caron, ed. Michèle Merger et Dominique Barjot (Paris: Presse de l'Université de Paris-Sorbonne, 1998), 381-92.

68. Leonard, Agrarian Reform in Russia, in particular figure 8.1, page 258.

69. Ian Blanchard, Russia's Age of Silver: Precious Metal Production and Economic Growth in the Eighteenth Century (London and New York: Routledge, 1989). 
70. Moon, The Russian Peasantry, 27.

71. VladimirM. Kabuzan, Izmeneniia v razmeshchenii naseleniia Rossii v XVIII-pervoi polovine $X I X v$. [Changes in the rate of growth of the Russian population during the eighteenth and the first half of the nineteenth century) (Moscow: Nauka, 1971); Alain Blum and Irina Troitskaia, "La mortalité en Russie au XVIIIe et XIXe siècles. Estimations locales à partir des Revizii," Population, 51 (1996): 303-28; Steven Hoch, "Famine, Disease, and Mortality Patterns in the Parish of Borshevka, 1830-1912," Population Studies 52, 3 (1998): 357-68. 


\section{Old Bondage, New Practices}

A Comparative View of the Russian, European, and Indian Ocean Worlds

This open access library edition is supported by Knowledge Unlatched. Not for resale. 
This open access library edition is supported by Knowledge Unlatched. Not for resale. 


\section{The Persistent Servant \\ Labor, Rules, and Social Hierarchies in France and Britain from the Seventeenth to the Nineteenth Century}

In this book, I do not intend to develop a full and original analysis of labor relations and rules in Western Europe; a huge bibliography is already available on this. I only wish to recall recent new trends in the relevant historiography and question the conventional view against the backdrop of the equally revisited interpretation of Russian serfdom. My intention is to raise general questions on the relationship between capitalism, markets, and coercion, on the one hand, and on the analogies and differences between Russia, Western Europe, and some of Western Europe's colonies, on the other hand.

Until at least the mid-nineteenth century, the term free labor did not mean what we are now accustomed to it meaning.; ${ }^{1}$ it included indenture, debt bondage, and several other forms of unfree labor; ${ }^{2}$ conversely, the official abolition of slavery did not see the disappearance of forced labor, but rather the emergence of new forms. ${ }^{3}$ In both cases, in legal terms, coerced labor was in fact "free labor."

In this increasingly complex picture, the historical transition from slavery to emancipation has also been reassessed. For example, in French, as well as in British and Spanish, colonies, personal emancipation often took a long time, with years sometimes elapsing between the deed signed by the owner and the tax paid by the quasi-former slave. During those years the ex-slaves had an intermediate status between that of a slave and a freedman. ${ }^{4}$

A similar though less impressive shift has been taking place in the understanding of the evolution of free labor in Europe. For ancien régime 
France, for example, it has been demonstrated that the division of society into old orders and corporative regulation had weakened greatly and, to some extent, even disappeared by the early eighteenth century. ${ }^{5}$ On the other hand, important status markers persisted under the liberal regime, for example in relation to the legal status of married women, children, and merchants. ${ }^{6}$

In a similar view, Britain is currently associated with the first historical proletarianization of the peasantry and the rise of a capitalistic labor market. While France, after long being considered a country in which guilds, heritage, and labor regulation had penetrated capitalism, has recently been associated with abolishing criminal punishment for breach of contract eighty years before Britain did so. This chapter reexamines these issues and shows the persistent importance of legal constraints on labor and of the legal inequalities between working people and their masters in nineteenth-century France and Britain.

\section{Labor Constraints in England}

We have already looked at labor laws in Britain when discussing Bentham's Panopticon, and it was in this context that I devoted a special section to the Poor Laws. We have now to complete this analysis by examining labor contract rules. The idea that capitalism and in particular the English Industrial Revolution was made possible thanks to institutions that facilitated free contracts and (according to some) a proletarianized peasantry is supported by a long tradition. It dates back to at least the nineteenth century and the classical economists (Smith, Marx), continuing through Tawney and Polanyi and through most works of historical sociology and economic history in the twentieth century. Even the world-system approach, while stressing the existence of mixed forms of labor and exploitation on the periphery and quasi-periphery, has always assumed that free wage labor typified the "core." However, in recent decades, several pieces of research have contested the impact of enclosure and the existence of a truly free labor market in industrializing Britain. ${ }^{8}$ I wish to further develop this view and connect labor law in Britain with the overall dynamics and rules of labor markets in Europe and Russia, as well as in certain European colonies. Thus, from the sixteenth to the nineteenth centuries, laws on runaway slaves and indentured servants were adopted not only in the colonial Americas, but also in Great Britain, where runaway workers, journeymen, and the like were subject to quite similar laws under the Master and Servant Acts and the Statute of Artificers and Apprentices of 1562. Apprenticeship, advances in wages and raw materials, and simple master-servant relations justified such provisions. 
From the sixteenth to the end of the nineteenth century in Britain and throughout Europe, despite the existence of a contract, free labor was considered the property of the employer and a resource for the entire community to which the individual belonged. ${ }^{9}$

In chapter 2, I already mentioned the relationship between Bentham's Panopticon and the forms of labor constraints in Britain, the Poor Law in particular. Here I will remind the reader of only a few aspects of this story: Since the mid-seventeenth century, the Poor Law related relief directly to workhouses. Any person lacking employment or permanent residence was no longer considered a "poor" person, but became a "vagrant," and as such was subject to criminal prosecution. Anti-vagrancy laws did not decline but became stricter in the nineteenth century, particularly after the adoption of the New Poor Law, in 1834. Between this year and the mid-1870s, there were about 10,000 prosecutions for vagrancy. ${ }^{10}$ Unlike prosecutions carried out under the Master and Servant Acts, they were conducted on the initiative of public authorities and did not respond to economic trends, but to political and social-order interests.

The workhouse system was far from marginal: it has been estimated that in periods of crisis during the eighteenth and nineteenth centuries, about 6.5 percent of the British population was in a workhouse at any given time. ${ }^{11}$ Many have seen a strong influence of Bentham in the New Poor Law (adopted in 1834), and certainly there was. The language of the law was similar to what Bentham had developed since the late eighteenth century. At the same time, after the initial favorable reception of the Panopticon ideas in the early nineteenth century, central British authorities were skeptical about adopting a generalized Benthamian system. The commission in charge of the New Poor Law insisted that workhouse labor would be applied for discipline rather than profit. ${ }^{12}$ Thus the years following the adoption of the new rules saw increasing number of paupers committed to workhouses for offences: the number of committals rose from 940 in 1837 to 2,596 by 1842 , while over 10,500 committals for breach of workhouse discipline were recorded during this same period. ${ }^{13}$

Yet many local authorities did not abandon Bentham's original idea and still hoped to cut their costs with workhouse labor, ${ }^{14}$ but this was by no means easy, for the organization of labor met huge difficulties, to start with, the massive presence of the occasionally poor-those who spent some hours in the workhouse. Such workers were mostly set to simple tasks such as carrying or breaking stones; however, they were entitled to claim their food before working, which created several conflicts with the workhouse authorities, who tended to provide food after the work had been accomplished, arguing that otherwise the occasional poor would not perform their task anymore. Paupers and inmates increasingly resisted 
the Poor Laws and the workhouse principle, resorting to petitions, sabotage, and, in particular among women, self-mutilation. ${ }^{15}$ If one adds the massive protests against the Poor Laws in the 1830s, one would have a complex picture in which different central government orientations faced equally various local elites' attitudes and popular protests. ${ }^{16}$ Yet this complexity cannot hide the outcome: the workhouse system was never profitable as Bentham had hoped, and it ultimately worked as form of social control aiming at influencing deviance and the broader labor market. Indeed, the history of workhouses has been one-sidedly linked to that of prisons, while the link with "normal" labor has been ignored. ${ }^{17}$ Indeed, this link was strong over centuries not only for the forms of discipline and rights, but also for the way wages and assistance were related. The Statute of Laborers (1350-51) was enacted two years after the Ordinance of Laborers had been put in place ${ }^{18}$ and was followed by a set of laws gathered under the umbrella of the Master and Servant Acts, which multiplied in the sixteenth century and accompanied the Statute of Artificers and Apprentices (1562). During the term of service, the labor of servants was legally reserved for their masters. Even at the expiration of the term of service, servants were not allowed to leave their masters unless they had given "one quarter's warning" of their intention to leave. ${ }^{19}$ Beginning in the second half of the sixteenth century, the tradition that viewed the master's legal control as property based became an important constituent of the new market society. Workers could be imprisoned until they were willing to return to their employers to complete their agreedupon service. Any untimely breach of contract on the part of the servant was subject to prosecution. The word fugitive was clearly employed for apprentices and servants who left without giving notice. More generally, servants' hirings were seen as agreements to do something in the future. As such, the labor of servants was considered the legitimate property of the master. In fact, in early-modern Britain, resident servants were like wives and children: all were members of the household and all were the legal dependents of its head. This implies, on the one hand, that servants, children, and wives were entitled to be maintained by the head of the household; on the other hand, all of them were supposed to be under his authority, the family head benefitting from a higher legal status and more legal entitlements and rights than his dependents and family. Both marriage and labor contracts were actually status contracts: they gave rise to a different legal status for wives and servants, on the one hand, and for masters and husbands on the other. Dependency was a normal part of a differential system of rank and degree in which everyone, adult and child, man and woman, had and knew his or her place. In general, labor 
was seen as akin to domestic service, with the employer purchasing the worker's time. ${ }^{20}$

Careful attention should be paid to the definition of servant. Like many lawyers, Macpherson refers to all forms of wage labor ${ }^{21}$ while Peter Laslett limits it to domestic servants. ${ }^{22}$ However, the word servant took on different meanings at different times, and the labor relationship did not consist of a single homogeneous legal status. For example, between the fourteenth and sixteenth centuries, contemporaries limited the word servant to particular wage workers who resided with their master, so laborers and artificers were not included under this rubric. However, from the sixteenth century on, the word servant was increasingly used to define any sort of wage earner and thus included journeymen, artificers, and other workmen. ${ }^{23}$

Confusingly, from the late eighteenth century on, judicial decision excluded domestic servants from the scope of master and servant statutes-at least in England; although in the colonies they usually were included. ${ }^{24}$ Special varieties of contract existed for mining, where an annual "bond" was in use, and for shipping, where seamens' labor agreements were widespread. As the leading British legal doctrine of that time put it, by owning slaves and war captives you owned things, whereas labor services meant that you owned a certain person's time. ${ }^{25}$ It was a lease of labor in which the borrower had the right to benefit from all the time and capacities of his labor force. As long as contracts for the hire of labor continued to be understood as conveyances of property in labor, contractarian individualism would continue to furnish support for unfree labor. Criminal proceedings accompanied the emphasis placed on contractual free will as a foundation of the labor market. Criminal sanctions were provided for because labor was free and the worker freely agreed to them. The measures were also applied to journeymen, unskilled workers, and in general, whenever short-term contracts to improve output were involved. Insubordination or failure to comply with workshop production rules were also considered a breach of contract without notice and as such were liable to criminal sanctions. ${ }^{26}$ Worse still, the measures of the Master and Servant Acts grew stricter starting in the 1720s, when penalties against servants who broke their contracts were reinforced. The first Industrial Revolution was backed by constraints on labor mobility that were tighter than ever. Between 1720 and 1792, ten acts of Parliament imposed or increased the term of imprisonment for leaving work or for misbehavior. Almost all these acts were a new departure: the Master and Servant Acts not only attempted to provide for social and political stability but required tighter control of workers by their masters while 
guaranteeing "fair" competition among masters (that is, they should not try to entice away other masters' working people). Specific groups promoted these changes: tailors, shoemakers, leatherworkers, mariners, and lace makers. Monetary or raw material investments made by the employer were used to further justify such sanctions against wage earners who left their jobs. ${ }^{27}$ Employers strongly supported this legal architecture; as late as 1844, in response to strikes and protests in mines, an attempt was made to extend the provisions of the Master and Servant Acts to all labor relations. Extremely widespread popular and workers' reactions against the bill stopped it from being approved. ${ }^{28}$

Thus employers also penalized outworkers, who received work to be done and then returned it to the employer when completed, if they retained the work too long. Starting in the mid-eighteenth century, magistrates rendered legal interpretations that were increasingly favorable to masters. This trend had its basis in the huge expansion of the putting-out system in the eighteenth century, which added to the mounting need for agrarian labor. ${ }^{29}$ Competition between sectors and the intense seasonality of labor strongly buttressed these new labor laws. ${ }^{30}$ The idea that high wages were necessary to encourage technological creativity, as expressed by Habakkuk and many others, ${ }^{31}$ is based on the false assumption that technological progress was primarily a choice between equivalent alternatives and that these choices depended on factory prices. ${ }^{32}$ However, there is no persuasive evidence that technological progress emerged as labor-saving in the eighteenth and the first half of the nineteenth century. Agricultural innovations in particular tended to be labor-using rather than labor-saving: the new techniques of husbandry demanded more labor, not less. ${ }^{33}$ Recent analyses come to the same conclusion: labor and labor intensity are identified as the main source of agricultural growth before 1850 , with human and physical capital playing a secondary role. ${ }^{34}$ Long after steam had become the dominant form of power employed in manufacturing, the major sources of energy available to farmers continued to be men, animals, wind, and water. ${ }^{35}$ Labor-intensive techniques linked to the diffusion of knowledge and attractive markets (with increasing agriculture prices) were dominant between the seventeenth and last quarter of the nineteenth century, when this trend reversed (decreasing agricultural prices and increasing wages). ${ }^{36}$ In Britain as in France, in agriculture, only 15 percent of the increase in worker output between the mid-eighteenth and mid-nineteenth centuries can be attributed to technical progress. The rest was owed to reduced leisure time and more intense work. ${ }^{37}$

This trend was not limited to agriculture. Casting doubt on traditional views $^{38}$ based on neoclassical models, ${ }^{39}$ recent analyses seem to show that the rate of capital intensification in British industry was relatively limited 
until the mid-nineteenth century. Christine MacLeod has discovered that the most frequently declared goal of innovation was either improving the quality of the product or saving on capital, not labor. ${ }^{40}$ Feinstein's estimations show that in Britain, the growth rate of domestic reproducible capital stock increased steadily, rising from 1 percent a year in 1760-1800 to 1.5 percent a year in $1800-1830$ and to 2 percent a year in $1830-60$. The labor force increased just less than 1 percent per year from 1760 to 1800 and just under 1.5 percent from 1800 to 1860 . Thus capital and labor grew at about the same rate from 1760 through 1830, with no effective change in the capital-labor ratio during these seven decades. In the last three decades, the ratio did rise, as capital per worker increased at a rate of about 0.5 percent per year. ${ }^{41}$ The rate of capital formation in Britain was relatively slow until the mid-nineteenth century; up to this time, the rate of labor/capital increased, and this tendency was reversed no earlier than the end of the nineteenth century. ${ }^{42}$ By 1850 , there were relatively few workers employed in factories; only a small proportion worked in technologically advanced industries such as cotton, iron and steel, and metalworking; the full impact of steam power in transport and production was yet to be felt. ${ }^{43}$

In cotton textiles, the number of machines per worker varied remarkably from region to region-by amounts as large as or larger than variations observed in agriculture. ${ }^{44}$ Such variations were even more significant in other industries. ${ }^{45}$ The unmechanized, subcontracted work of the sweating system surely played a greater role in the intensification of work than did mechanization. ${ }^{46}$ Annual household earnings rather than the daily wages of individuals became the key variable, the participation of wives and children being crucial. De Vries's notion of an "industrious revolution" explains this trend perfectly. Participation of all the members of the household in the labor market and increasing incomes despite falling nominal (and sometimes real) individual hourly and daily wages justified both increasing budget expenditures, the growing labor effort, and the persistent high demand for labor before, during, and after the first Industrial Revolution. ${ }^{47}$

Yet this solution did not always prove to be effective or ensure a stable workforce for industry, because first of all, the unions strongly protested against the employment of children and women and therefore sustained the strategies of those entrepreneurs who introduced long spinning mules, for which only skilled men were required. Seasonal needs in agriculture were the crucial variable here. In Russia, but also in Britain, France, Germany, and the Netherlands, seasonal local shortages of manpower were overcome by interregional migration and-only later in the nineteenth century - by a transformation of hand-harvesting techniques 
and tools. ${ }^{48}$ In fact, the labor requirements of harvesting were particularly important since labor output peaked sharply at the harvest. The critical factor affecting the proportion of families assigned to agriculture was the degree of seasonality of labor requirements, because seasonal workers were necessary, but only for short intervals of time. ${ }^{49}$ Yet detailed data show a strong regional and gender differentiation. Throughout the eighteenth and into the mid-nineteenth century, male employment in agriculture experienced a peak in the summer and a low in winter. Conversely, women moved progressively from a seasonal situation similar to that of men to growing employment in spring farming activities, these being associated with livestock. ${ }^{50}$ All this showed a clear link between agriculture and organizational forms of industrial labor. English labor markets had a great seasonality, since the labor requirements of grain production (still dominant in Britain and France) were far more contingent on the season than were those of the other major agricultural products of the era (animal products, wood for fuel or timber, and cleared land) and because agriculture was a major sector. In turn, this provided a rationale for the putting-out system that was still common in England (and even more so in France, as we will see) into the late nineteenth century. It was important not only in skilled industries such as pottery, but also in textiles. ${ }^{51}$ Indeed, the extent of seasonality was crucial, because the flexibility of cottage manufactures that was based in workers' ability to choose the time and circumstance of their work gave this form of manufacturing organization a relative advantage in the use of part-time or seasonal labor ${ }^{52}$ From this perspective, cottage manufacture could compete with the technically more efficient manufactories, because it was more effective at harnessing a part-time or off-peak workforce whose opportunity cost was low. Fluctuations depended on the relative strength of manufacturing, agriculture, and proto-industry; in most of the countries concerned, and even in some British areas, agriculture and proto-industry until the 1850s dictated labor availability to industry and not the reverse. Until the mid-nineteenth century, double employment (mostly in rural and urban areas) was the rule rather than the exception not only in Russia and France, but in Britain, as well..$^{53}$ Of course, as our evidence shows, this trend was much stronger in textiles than in other industries such as metallurgy, where stable workforces and increasing mechanization existed since the early nineteenth century. Yet instead of refuting our main argument, this issue confirms it: the leading industries of the first Industrial Revolution were much more labor-intensive than usually assumed, at least until the mid-nineteenth century. After that time, mechanization accelerated with the second Industrial Revolution and the emerging of new, highly capital-intensive industries. 
All this helps explain the main features of labor contracts. The labor market did not operate as an "auction market" 54 for several interrelated reasons: there was no unlimited supply of labor, in particular of skilled labor; the peasant-worker and unskilled workforce were the leading actors; and the Master and Servant Acts aimed at providing a tool with which masters could discipline the labor force and fix wages outside the market mechanism.

By the eighteenth century, an oral or written contract for workers other than day laborers was presumed to last a year, particularly in husbandry, unless specific terms had been explicitly negotiated. A one-year contract was the rule for skilled workers, but they were relatively widespread among unskilled labor as well during strong economic upswings. Such a general hiring was presumed to continue unless three months' notice was given on either side. The requirement of advanced notice was intended to afford employers enough time to replace departing workers and avoid sudden stoppages. Day laborers were often employed at random for some weeks. However, the frequency of departures, mostly in connection with the harvest, proved the relatively limited impact of the law on workers' behavior. Masters therefore looked for other solutions, such as the possibility of workers subleasing looms and tools and finding a substitute. ${ }^{55}$ This solution was particularly widespread in textile mills, where family members who received a family wage usually worked small spinning mules. ${ }^{56}$

Up through the mid-nineteenth century, the demand for seasonal harvest labor was met mainly by local sources of supply; and long-distance migrants, often from pastoral regions or towns, were not able to easily adjust to random fluctuations in local labor demand. ${ }^{57}$ In general, shortterm contracts allowed employers to lay off workers when there was a sudden downturn of trade or if workers became troublesome. Workers were not liable to criminal punishment and could leave immediately. A positive trend in business, with little unemployment, made short-term contracts favorable to workers; the reverse was true when unemployment rose. Even if some firms in Lancashire had developed alternative strategies of "fair wages" since the mid-nineteenth century, ${ }^{58}$ they seem to have been a tiny minority. Most masters and employers waged war on wage laws and exacted criminal punishment to obtain the required amount of labor. This had its basis in the idea that the poor tended to shirk hard work and that higher wages would produce the opposite effect: reducing the supply of labor.

Were these rules enforced?

Historians who have studied criminal sanctions in late eighteenth- and nineteenth-century Britain have depicted them as anomalous rules in a 
market society with a large population of proletarians. Detailed analyses have recently been carried out on the rate of penalty enforcement in the courts of Great Britain. ${ }^{59}$ Coercion took different forms: the obligation to work under the New Poor Law and the anti-vagrancy laws; penalties for violating the factory regulation; and penalties for infringing the Master and Servant Acts.

We have already looked at the first form of coercion, its meaning and high degree of enforcement, which responded to public order goals and was enforced in response to social and political dynamics. Factory discipline was also extremely widespread; most masters preferred to mobilize these rules instead of using wage incentives to obtain punctuality and respect for the company's organizational and technical rules. ${ }^{60}$ In most cases, masters sought to convert infractions of factory discipline into Master and Servant offences. The county and police-district records for the years 1857 to 1875 show that some 10,000 people were prosecuted each year for Master and Servant offences. Of those, 7,000 were convicted; 1,700 served sentences in a house of correction; 2,000 were fined; and 3,300 received other kinds of punishment (wages were abated and costs were assessed). Whipping was extremely rare (11 people in 1857; 2 in 1858 and 1859 ; 1 in 1860; and 1 in 1866). ${ }^{61}$ Overall, 5-8 percent of servants were prosecuted, but the percentage reached as high as 17 in some areas and even 20 in London, in certain years. There were no significant differences between the prosecution rate under the Master and Servant Acts in rural areas as opposed to urban counties, or between agricultural, putting-out, and manufacturing areas. ${ }^{62}$ Instead, the response to changing economic trends and the rate of prosecution was stronger in the countryside than in town, ${ }^{63}$ most likely because of the major impact of seasonal labor shortages on agriculture.

The eighteenth century saw sharp increase in the number of prosecutions, and within this time period were shorter trends that appear to have significantly correlated with the rate of activity and employment. Thus the higher the rate of employment, the higher the rate of worker prosecution. This was not because coercion was higher where people were fewer in number, but because labor markets were segmented and regionally based and because working people actually performed multiple tasks over the year. It also explains why employers did not want their workers imprisoned but rather back at work. Most of these conflicts were solved outside the courts, in particular disagreements between masters for practicing unfair competition, while prosecution of servants was exemplary. For the most part, masters wanted their workers and servants to return to work for them. Legal commentators were very clear that the purpose of the legislation was not so much to punish wrongdoing but to compel 
work performance. ${ }^{64}$ There is evidence that employers launched criminal procedures mostly against workers whom they did not want to returnjust to set an example.

In addition to long-term trends and prosecutions linked to overall business activity, seasonality seemed to play a serious role. Douglas Hay has carefully quantified this phenomenon: most prosecutions were held in summer, during the harvest, while fewer prosecutions were recorded in the winter months and in October, when most contracts were renewed. At the same time, there were regional variations-depending on the importance of breeding (i.e., female labor in the springtime), of putting-out, of manufacture, and of the particular kind of agriculture involved. For example, in places were the silk industry dominated, the adjudication of disputes took the form of mutual adjustments within the existing structure instead of attacking that structure. This was the case either because (as in Coventry) common lands encircling the town prevented expansion and dilution of trade, or because (as in London) riots and sabotage were easy to carry out and difficult to repress. ${ }^{65}$ Strong regional differences were observed: Worker initiatives account for about 40 percent of cases in Bedfordshire, in 1810-14; for 14 percent in Herefordshire, Gloucestershire, and Worcestershire, in 1801-13; but for only 4 percent in Buckinghamshire, in 1800-1807. Despite these differences, the success rate was almost 100 percent for masters and between 20 and 70 percent for servants in different counties. ${ }^{66}$ These different rates of prosecution can be related to several factors: the economic trend, the local situation, the ideology of labor, and its judicial interpretation. Apprentices were placed under the general Master and Servant Acts. Hay's data show that for every apprentice who denounced a master for mistreatment or unpaid wages, three masters brought apprentices before a court for lack of respect, undue absence, etc. No masters were punished, while the number and percentage of children sent to prison increased in the 1830s and the 1840s. The percentage of convicted children sent to prison was around 30 percent in London, 26 percent in Gloucestershire, and 39 percent in Staffordshire. These figures did not fall until the 1860s. ${ }^{67}$

In contrast, masters and employers were not subject to these measures; the first rulings in this sense occurred in 1844, at the precise time that the Poor Law was eliminated. ${ }^{68}$ Until that point, masters were never threatened with imprisonment for breach of obligations, ${ }^{69}$ but after that, it is unclear whether official statistics included worker-initiated actions. Steinfeld says they did not; however, archival inquiries show that a certain percentage of prosecutions under the Master and Servants Acts were initiated by workers against their employers, mostly for back wages or wrongful dismissal. ${ }^{70}$ As noted above, the different rates of prosecution 
can be related to several factors: the economic trend, the local situation, the "ideology" of labor, and its judicial interpretation. For example, most judges aimed at social and political stability, this last being identified with wage stability and fair competition between employers in periods of labor shortages and/or increasing economic activity. This was true in particular for skilled and long-term servants. For day laborers, the rate of prosecution was not significantly different from workers in manufacturing, and it was also seasonally determined-highest in periods of heavy agricultural work, when people shuttled between town and countryside. This corresponded to the terms of contract for agricultural laborers, who were paid only at the end of their contract, precisely to avoid this kind of problem during the harvest season. The masters frequently prosecuted servants engaged in occupations that were half agricultural and half trade and who, in their eyes, had failed to perform the entire promised service; from this standpoint, the enforcement confirms what our discussion of rules has already evidenced - that the Master and Servant laws were tools for reducing employment=turnover costs.

New evidence on the rate of prosecution over time suggests that increasing labor demand was strongly associated with prosecution for breach of contract. Out of these periods, the rate of prosecution was lower in industries and districts where employment was more stable. ${ }^{71}$

Thus the long-term movement of labor and its laws in Britain hardly confirms the traditional argument that early labor freedom in the country fueled the Industrial Revolution. On the contrary, the Industrial Revolution was accompanied by increasingly tough regulations and criminal sanctions on workers. Master and Servant Acts were a powerful tool in the hand of masters/employers in filling the increasing demand for labor in the eighteenth and nineteenth centuries. Criminal law became harsher for workers during the Industrial Revolution, and the prosecution rate increased as well. The new Master and Servant Acts were not vestiges of feudal times but a clear response to the new industrializing context. They fit the ambition of judges and British political elites to secure social and political order through laws addressing the poor, vagrancy, and labor. In fact, without this support, the attitudes of the masters would probably not have sufficed to ensure this progressive enlargement of criminal law. Masters criticized unreliable servants and workers, but they also did not hesitate to entice away other employers' workers. Competition was particularly strong in towns but also existed between urban and rural activities. For the reasons mentioned above, economic growth from the seventeenth through the mid-nineteenth century was often labor intensive, and even when more capital was demanded, it led to greater employment of the labor force. This trend was a response to the persistent attitude 
of most employers (not only industrial ones, but also heads of family, especially in the countryside) and public officers, who considered labor a service. We now better understand Bentham's attitudes as discussed in chapter 2 . The legal status of labor provided the common ground for the organizational concerns of the firm (or estate) and the poor relief system. From an economic perspective, the Master and Servant Acts responded to a market in which labor was the most important resource; these rules therefore offered masters a solution to guarantee the desired labor force, in particular during periods of shock demands on the labor market. At the same time, criminal penalties were mostly enforced in areas and industries where mobility was greater. From this perspective, contract enforcement was a substitute for higher wages: masters used it as long as they could, in order to secure labor. Unfortunately, this choice did not solve the problem, for many workers were peasant-workers and wished to go back to the countryside during the harvest or at times of major agricultural activities. Given the strong family ties between the town and the countryside, only persistently increasing earnings would have encouraged permanent residence in town. But most masters preferred to use coercion rather than attractive wages to keep the labor force, and they thus ultimately encouraged "fugitive" workers. The situation could change only with accelerating technical progress in both agriculture and industry, creating a capital-intensive path of growth. As we shall see, this occurred only after 1850, with the second Industrial Revolution and the increasing expulsion of the working force from agriculture.

We may now ask to what extent British laws found their parallel elsewhere in Europe. In particular, we will be looking at France, since current legal-historical analysis often presents this country as a partial exception to the British path, in that criminal sanctions against breach of contract were precociously abolished. We may ask whether this is true and, if so, for what reasons and with what implications for wider social and economic dynamics.

\section{A French Exception?}

From a historical perspective, the institutional status of labor in France can be divided into two main topics, both of which have generated debate over continuities and breaks with the past. On the one hand, there was the legacy of the guilds and how they were abolished, and on the other, there was the long-term process of ending slavery and its legacy in the colonies. In each case, the object of analysis has been unjustifiably restricted. The analysis of labor in France has overlooked work outside of guilds and, above all, in agriculture; and in the analysis of labor in the colonies, 
slavery has received far more attention than other forms of bondage. My aim is to readdress the issues surrounding the institutional status of labor and its practices, as well as how they were passed on over time, by focusing on agricultural laborers and engagés and ultimately on the historical relationship between these two groups.

In the past, historians have been fond of opposing the persistence of guilds and the corporatist spirit in French labor law to the free market of Anglo-Saxon labor. ${ }^{72}$ This contrast is no longer relevant and the regulation of labor in France is no longer viewed as being in opposition to market growth. ${ }^{73}$ From this standpoint, what is important is that France appears to be the first country to have abolished lifelong domestic service as well as criminal penalties in labor disputes. ${ }^{74}$ The chronology of these developments requires further explanation.

As late as the eighteenth century, France's leading legal experts considered labor to be a service provision..$^{75}$ Moreover, French case law made no clear distinction between hiring a person for services and "hiring" a thing. Similarly, apprenticeship contracts and domestic service contracts of longer than a year obliged individuals to place all of their time in the service of their employers, ${ }^{76}$ which prompted the writers of the l'Encyclopédie méthodique to denounce such contracts as "slavery." 77

Although the French Revolution eliminated lifelong domestic service, it retained both forms of contracts from earlier periods: hiring for labor (louage d'ouvrage) and hiring for services (louage de service). While the former brought the status of the wage earner more in line with the independent artisan, the latter represented an important legacy from earlier forms of domestic service. Cottereau has emphasized the importance of hiring for services in nineteenth-century France and its ability to protect wage earners. Such contracts and the overall attitude of prud'homme law courts strongly protected workers. ${ }^{78}$ This argument, while not false, is restricted to the fields studied, i.e. the textile industry and certain urban milieus. But what about the other sectors, especially agriculture?

Both before and after the revolution, legal text classified working people in agriculture as laborers or "task workers" (tâcherons), or still as servants in husbandry. ${ }^{79}$ In the eighteenth century, servants in husbandry were by far the largest group of wage earners in French agriculture, as well as in Great Britain. ${ }^{80}$ In the nineteenth century, official statistics reported by Mayaud show that day laborers were commonly found in the southern Mediterranean, Alsace-Lorraine, the Île-de-France, and Picardy. It is estimated that in 1862 about half of the 4 million agricultural wage earners were day laborers; thirty years later, that figure dropped to 1.2 million. The trend was linked in large part to a sudden reduction in the number of small landowners, between 1862 and 1892; by contrast, servants 
in husbandry made up an increasingly high percentage of agricultural laborers. ${ }^{81}$

The problem with this analysis is that these statistical classifications and categories fail to convey the fluidity of institutional definitions of agricultural (day) laborers (journaliers), pieceworkers (tâcherons), and domestics (domestiques) or how these actors used these definitions. Prior to the revolution, penalties were imposed on all laborers, pieceworkers, or servants in husbandry who quit their jobs before the end of their contract or without the employer's authorization. A variety of contractual arrangements to limit mobility existed at the time (bonuses for hardworking laborers, payment by task) along with general provisions. ${ }^{82}$ Thus from the sixteenth to the eighteenth century, agricultural laborers and servants were free to move about and change employers only at certain times of year-that is, according to the critical periods in the agricultural calendar. In some regions, mobility was permitted around the feast of Saint Martin (11 November), i.e., between the end of the harvest and the beginning of winter; in others, it was around the feast of Saint Jean (summer solstice) or at Christmastime. ${ }^{83}$ The seasonal nature of agricultural labor gave rise to a significant amount of regional mobility, which was already considerable in the seventeenth century and remained high until around the end of the nineteenth century. ${ }^{84}$ This mobility, together with the notion of labor as service in the legal and economic culture of the time, is precisely what helps to explain the harsh penalties imposed on laborers and servants. They were not allowed to leave their masters until the end of their contract, and if they left prematurely, they were subject to heavy penalties as well as the loss of their earnings. The master, on the other hand, could discharge them at any time. ${ }^{85}$

Little research has been done using legal sources to study agricultural labor in the postrevolutionary period-like the work Cottereau did on certain select industries. One of the exceptions is the thesis of Yvonne Crebouw, ${ }^{86}$ which is based on local customs recorded in France during the last quarter of the nineteenth century. Indeed, when studying institutions and labor standards in the countryside we can make use of two main sources, both of them considerable, although they have seldom been used until now: local customs and the archives of the justices of the peace. Practices were inventoried and published in great numbers during the second half of the nineteenth century in response to two parliamentary investigations. The first was launched in 1848 , the second in $1870 .{ }^{87}$ This reflected a more general trend under the Second Empire to codify local customs in trade, labor, land ownership, etc. ${ }^{88}$

Several groups (chambers of commerce, landowners associations, local elected officials) originated this request for codification of customs; 
indeed, as it appears from records of local meetings and the occurrence of disputes, there was no longer a consensus about the content of one or another local custom. Publishing those practices was an attempt to compose a certain picture of these customs at the very moment when they were beginning to fragment. The anthologies of customs, which were quite numerous, ${ }^{89}$ along with the aforementioned parliamentary investigations and revolutionary archives, ${ }^{90}$ constitute important and easily accessible sources on labor relationships in agriculture.

These sources can be compared with the archives of the justices of the peace available in departmental archives (series U4), keeping in mind that the legal statistics indicate that in the nineteenth century, many more labor disputes were brought to justices of the peace than to the industrial tribunals (prud'hommes). ${ }^{91}$ This can be explained in part by the fact that justices of the peace had exclusive jurisdiction in lieu of industrial tribunals, which were often not present in rural areas. Unlike the British justice of the peace, the French juge de paix was a trained lawyer. Thus even where industrial tribunals were present, justices of the peace decided all cases concerning limited amounts of money. Disputes over the wages (gage $)^{92}$ of "servants in husbandry" and laborers was one of the areas reserved for justices of the peace, ${ }^{93}$ especially because masters were taken at their word (until 1868), unlike their dependents, regarding any issue concerning gages, wages, or advances (art.1781 of the French Civil Code).

In the event of a dispute, a justice would above all try to identify the kind of case involved, attempting to ascertain whether it involved a daily laborer, domestic servant, or pieceworker; however, it was by no means easy to distinguish among them. For example, the wage unit for laborers was a single day, this corresponding to a unit of work. The length of the workday was the same throughout a given region; it took into account meals, travel time, and rest periods, but it differed from one season to the next, and wages changed along with the length of the workday. Unlike the payment for those hired for a specific task, the daily laborer's workday was paid at an agreed price, regardless of the amount of work performed; this led farmers to seek out pieceworkers.

A daily laborer could leave his employer at any time or be discharged without prior notice - and without providing or claiming any compensation. In practice, however, the need to ensure hands for urgent labor had an obvious corrective effect on this rule. For example, a laborer paid by the day might be kept on for one or two weeks, or even a month or two, in the summer and autumn. In some regions, incidentally, there were forms of journeyman contracts for six months or a year. In any case, the journeyman as well as the employer could go back on his word without prior notice. 
Indeed, laborers remained free to propose their services to several farmers, if their schedules permitted. Yet as Crebeuw notes, both the wage earner and the master paid for this freedom: the journeyman's employment status was precarious and he ran the risk of seasonal unemployment, while the employer faced a possible shortage of hands during peak seasons.

Was this reason enough to prefer officially declared piecework?

Indeed, this mode of hiring created a few reciprocal obligations: the laborer was supposed to finish the task he undertook, and the employer was not to discharge him without serious reason until its completion. But many exceptions were made to this rule, for example in the Nord, Cher, and Marne départements, and as a result, the difference between the commitments of pieceworkers and laborers remained vague in practice and difficult to determine in the event of a dispute. In essence, the two contracts were often combined, thus leaving the parties the possibility of emphasizing one or another aspect of the relationship depending on the particular situation. ${ }^{94}$

Lastly, domestic servants were most closely tied to their masters. This was not due to the work they performed (e.g., domestic chores), but rather to their residence and commitments. In the anthology of local customs in Châtillon-sur-Seine, a domestic servant was defined as a person who hires out his labor; is committed to serve someone; belongs to the household; takes part in the master's work; lives with the master; and who receives wages from him, which are designated as gages. ${ }^{95}$ In the Orléans region, domestic servants were "wage-earning servants [à gage] who helped the master in agricultural labor and were housed and lived in his home." ${ }^{\prime 6}$ The length and continuity of the commitment were also commonly mentioned in the anthologies of customs. ${ }^{97}$

What defined domestic servants and differentiated them from other agricultural wage earners was the nature of the contract, i.e., the content of the commitment, which was almost always tacit and which could not be broken "except for the most serious reasons." Domestic servants were subject to their master's will, which meant they "owed all [their] time to the master for any labor demanded." This subordination to the master's will resulted in making the promised gages in a lump sum. Of course, the master did not know the value of the service on which he could count, but "the servant cannot know the amount of work that will be required of him, nor the quality of the benefits in kind that he will be granted." These mutual uncertainties were the source of numerous cases of "infidelity" (on the part of the domestic servant) or of "exploitation and bondage" by the master, as they were described to justices. The master could discharge the domestic servant without notice or compensation 
for "dishonesty," "disobedience," "forgetting duties," cursing, or acts of violence. The domestic servants, for their part, complained of poor or inadequate food. ${ }^{98}$

In any event, problems arose most often with regard to the gage. Most practices allowed the master to withhold wages equivalent to the amount of work due from the wage earner. This led to the proposal, renewed in 1848, to extend the worker's booklet (livret ouvrier) ${ }^{99}$ to agricultural laborers; however, the measure failed to pass. On the other hand, if the domestic servant demanded compensation, he had no other recourse but the justice of the peace. Such a threat was frequently brandished but far less frequently carried out. Bills were presented in 1848, 1849, and 1850 to change the situation of domestic servants, which the bills' promoters viewed as a throwback to domestic service under the Old Regime or even as slavery. However, these bills also failed to pass, and the counterargument that "the domestic servant voluntarily subordinates himself to the master" prevailed. ${ }^{100}$

The situation changed during the second half of the century, when the rate of disputes went up ${ }^{101}$ and the demand for agricultural wage earners and domestic servants increased due to emigration to the cities. Employers accused the justices of the peace of being "on the side of laborers and domestic servants" 102 _ just as manufacturers during the same period accused the magistrates on industrial tribunals of being biased against them. ${ }^{103}$

In short, before the revolution, the status of French laborers and domestic servants resembled bondage; considerable limits on mobility and high service requirements were the norm, along with pronounced inequalities of status between working people and their masters. Labor was assimilated to service provision. In the nineteenth century, although domestic servants and laborers were held far more accountable than their employers for breach of contract, they were no longer governed by criminal constraints, but merely by civil law. This marked a fundamental difference from the pre-revolutionary period. ${ }^{104}$

\section{Conclusion}

Our study has revealed surprising continuities in the space and time of labor institutions and practices. Continuities are important in Western Europe between the seventeenth and the mid-nineteenth century, and similarities between Western Europe and Russia are also striking. In Europe, between the sixteenth and the end of the nineteenth century, the barrier between freedom and bondage was not only moveable and negotiable, but it was also thought of in a manner different from how we 
are used to thinking of it today. In fact, labor was submitted to serious legal constraints, including in relation to apprenticeship, wage advances, land, raw materials and seeds, and so on. Runaways included not only slaves in the colonies, but also servants and apprentices, and all of them could find themselves subject to criminal, as well as civil, penalties. Laboring people in Western Europe were neither economic actors freely choosing their activity as entrepreneurs or workers (as in neoclassical and liberal economic theory), nor were they proletarians in the Marxist sense. Instead they were legally considered servants or domestiques (in France), and, from a social and economic perspective, the peasant-worker was the leading actor. The evolution of institutional and social order interacted and gave rise to a complex chronology that hardly corresponds to those we are used to (the passage from feudalism to capitalism, from bondage to freedom, from self-sufficient to market societies). Throughout the period studied here, free and unfree forms of labor were therefore far more concurrent than opposed to one another, and many forms of unfree labor were actually still considered free engagements. Coercion was not incompatible with market and capitalism, rather it was fully integrated into it. ${ }^{105}$

This was so for several interrelated reason: in Russia as in Europe, between the seventeenth and the mid-nineteenth centuries, labor was legally considered a service. These institutional concerns interacted with economic trends; during the period under consideration, all over Eurasia, unprecedented labor-intensive economic growth occurred. In most European and Russian areas, agriculture did not turn into a simple supplier of produce and workforce for industry; quite the contrary, estates and peasants took part in the development of local and national markets, for both wheat and proto-industrial products. In this context, our conventional images of agrarian capital have also changed; in traditional historiography, England supposedly had higher livestock densities than other European countries and even higher in comparison with Asia. Indeed, in many parts of England, livestock densities were stable throughout the modern period until the mid-nineteenth century; ${ }^{106}$ conversely, there was more livestock in Asia and Eastern Europe at the time than is commonly believed. ${ }^{107}$ The gap in livestock density is therefore not so important and hardly explains growth. In England, the increase in yields that occurred before 1800 cannot be explained by rising livestock numbers. ${ }^{108}$ On the rest of the continent as well, the long-term trend of rising wheat prices (roughly between 1680 and 1815) led to a reduction of the surface area devoted to livestock and livestock feeding while increasing the acreage of wheat cultivation. Mechanization was therefore a relatively unimportant component of the changes in agriculture technology up to the mid-nineteenth century, ${ }^{109}$ 
when the appearance of commercial fertilizers and the development of mechanical harvesting equipment began to significantly affect methods of production. ${ }^{110}$ Until the machine age, i.e., until 1850 , much of the rise in productivity resulted more from the intensive use of known technology than from novel methods. So-called new husbandry was indeed not so new ${ }^{111}$ and it required more labor, not less. Only in agricultural systems like those in the United States, characterized by the high opportunity cost of labor, did economic pressure to mechanize come to resemble that experienced by some sectors of industry. On the contrary-in Russia and France as well as Prussia, from the seventeenth century through the second half of the nineteenth century, not only was labor the major input in agriculture, either directly or embodied in land improvements, but its importance became even greater. ${ }^{112}$

Labor and labor intensity were the main source of agriculture growth before 1850 , with human and physical capital playing a secondary role. ${ }^{113}$ Such labor-intensive techniques linked to the dissemination of knowledge and attractive markets (with rising prices for agricultural products) were widely used between the seventeenth century and the last quarter of the nineteenth century, when-as we see in the last chapter-this trend reversed (agricultural prices went down and wages went up). ${ }^{114}$

However, increasing demand for labor in agriculture had to compete with similar processes in proto-industry and manufacturing. From the end of the seventeenth century proto-industry developed in Western, Central, and Eastern Europe, in response to market demand and demographic pressure, ${ }^{115}$ and it retained its central position all over Europe until at least the mid-nineteenth century. Only after this time did some areas begin to decline and manufactures and industries start to replace the putting-out system. ${ }^{16}$ However, the shift was by no means complete, and in many European areas and districts, proto-industry continued to play a leading role during the second half of the nineteenth century and even in the twentieth century. ${ }^{117}$ In many areas of Russia and Western Europe, increases in agricultural output and income led to a growth in demand for manufactured goods, which was met by an expanding rural industry using labor-intensive technology. The resulting growth in rural nonagricultural activity in turn generated increased incomes for rural households and hence greater demand for agricultural output. The persistent, global strength of agriculture and proto-industry had an unanticipated effect, however. Urbanization and the supply of labor for urban manufacturing were mostly seasonal. Until the mid-nineteenth century, double employment (rural and urban) was the rule rather than the exception not only in Russia and France, ${ }^{118}$ but in Britain also. Here, the census and statistical error margins for the larger occupational groups such as agriculture, 
commerce, and manufacturing trades, are probably within the range of minus 40 to 66 percent! ${ }^{119}$ These activities were extremely problematic for rising manufacturing and industry, which, like the other parts of the economy, mostly relied upon labor. Because the price of capital was still high, urban employers sought to cope with labor shortages by putting legal pressure on laborers, who were not allowed to leave before the end of their terms, as well as on competitors, through strong penalties for unfair competition, etc.

But this persistent and global strength of agriculture and proto-industry had an unanticipated effect: urbanization and the supply of labor for urban manufacture were mostly seasonal. The huge demand for labor within the family, in the village, on the estate level, in agriculture, and in town was accompanied by persisting constraints on labor mobility. Local variations within a global labor-intensive trend produced intense interaction between economies, societies, and institutions, all stressing the role of labor and the institutional constraints on it.

Demand and labor-intensive growth were global features of societies and economies between the seventeenth and the mid-nineteenth centuries. In Russia (as well as in Poland and Prussia), legal constraints took a more severe form than in many Western European areas because of the political strength of estate owners, one the one hand, and because of their ambition to penetrate new industries, on the other hand. Contrary to traditional views, many estate owners were not against "progress"; they just wanted to keep urban merchants and producers out of the market, and they succeeded. This issue and not bondage or legal constraints on labor were the peculiarities of Eastern Europe.

This entire complex set of global dynamics helps to explain why Russia looks like an extreme variant of the European model instead of its opposite. Russia took part in the same process of growth, led mostly by demand and by being anchored to small units and labor-intensive technical solutions. Russian agrarian elites were not always opposed to the market and technical improvements, just as Russian peasants and their European counterparts were far from being hostile to the market. Of course, beyond analogies, differences among Russia, Britain, and France are important. In Britain the Glorious Revolution and the first Industrial Revolution did not establish a free market but reinforced the Master and Servant Acts and legal inequalities between masters and workers. At the same time, trade unions were precociously recognized since the early nineteenth century as political and social actors on the labor market. This went along with a slow transformation of the agrarian social landscape, in which landlords did not necessarily turn into capitalists; enclosures progressed at a very slow path until the mid-nineteenth century; and as a consequence, peasants went 
on moving between the town and the countryside. The putting-out system and, above all, the enlarged manufacturing sector entered a general Smithian growth that persisted longer than Smith or Marx had argued it would, i.e., until the mid-nineteenth century.

In France, the revolution abolished criminal punishment for breach of contract but did not put an end to the prohibitions against unions. This meant that masters and employers could not sue workers under criminal penalties but made large use of monetary fees. Workers could not rely upon unions, but found an ally in the prud'hommes courts. From this perspective, the French labor market was closer to a competitive market than the British one was. Yet this trend had to confront the institutional supports given to the peasantry and small rural estate owners, which encouraged the persistent peasant-worker and proto-industry and added regional and sectorial rigidities to the labor market, thereby compensating for competitive rules that existed on the urban and industrial market. However, the importance of the peasantry was not synonymous with self-subsistence. Quite to the contrary, it expressed a strong proto-industrial development. The peasant-worker was much more important in France than in Britain, but despite this, criminal punishments for breach of contract were never reintroduced. Control of wages passed through the interdiction of unions and the industrial law courts. As in Britain, old agrarian aristocracies survived the transient passage from the old regime to the new one. As Arno Mayer correctly stated many years ago, the end of the old regime in Europe-not only in Austria and Prussia, but also in Britain and France-was a consequence of World War One, not of the Industrial or the French Revolution.

If this is so, then, the Russian specificity consisted in adopting extreme variations of Western solutions. Estate owners entered the proto-industrial and cereal markets at the expense of urban merchants and producers and occasionally to the detriment of new "bourgeois" estate owners. This outcome was politically relevant and specific in that it expressed an extreme defense of old agrarian aristocracies in a context of progressive transformation of the peasantry. In terms of economic growth, this solution was far from catastrophic and confirms that markets and capitalism do not necessarily stand upon democracy and free labor. In tsarist Russia, tensions rose, as we will see in the last chapter, because of the irruption of the second Industrial Revolution and the disintegration of the peasant household. Both these process introduced a radical instability in the countryside and in Russian society as a whole.

These comparisons in national and area dimensions are valid only as a rough approximation. No doubt, legal rules (civil, tax, and customs laws) and political hierarchies refer to the national dimension of these 
phenomena, yet these rules were only one of the components of economic action, along with symbolic, cultural, and political aspects. At the same time, we cannot ignore the importance of local components and the great differences between the dynamics of different regions within a single country. The forms of forced labor - the existence of bondage or even slavery alongside free labor-often varied from one city to the next and from one place to another. This observation is especially relevant in our case, because the institutions and economic activities we are studying were extremely fluid, multiple, and locally based, from the eighteenth to the early twentieth century. Several institutions coexisted on the local level; even when a process of national unification took place, institutional pluralism continued. Local practices and customs played an important role, and they were recognized in nineteenth-century Russia with regard to property and in England and France with regard to work discipline. These elements account simultaneously for common phenomena (restrictions on labor mobility), the diverse ways they were expressed, and their source (worker's booklet, Russian serfdom, criminal punishment in the British Empire). They also explain the differences in the dynamics of Lancashire, the south of France, and western Russia, as well as those between individual English or French factories. As we have seen, in Russia, as in Britain and France, different solutions were adopted within a few miles of each other, and similarities developed more frequently with factories and estates in distant regions than with those nearby. These results confirm the similarities between certain Chinese regions and English districts, which have been the subject of recent research, ${ }^{120}$ just as much as those between proto-industrial districts within Europe. ${ }^{121}$ The major importance of local specificities transcends nation-state boundaries and perspectives, and suggests two major insights: between the seventeenth and the mid-nineteenth century, local dynamics and market stickiness encouraged global connections, on the one hand, and legal constraints on labor markets, on the other. Regional variations in the labor markets were associated with multiple activities and residences in labor-intensive economies. In such economies, seasonal and local fluctuations in labor markets were linked with constraints on mobility and unequal rights. At the same time, as the circulation of knowledge and practices between Russia and Europe shows, the importance of the local level (the estate, the firm, the village), did not oppose, but enhanced, global connections. National markets still lagged far behind local and international markets. This link between local and global markets, on the one hand, free and unfree labor on the other hand, is even more evident when one considers Western countries and Russia not as nation-states but as empires. In the following pages, I introduce this dimension to our analysis. 


\section{Notes}

1. Tom Brass and Marcel van der Linden, eds., Free and Unfree Labor: The Debate Continues (Berne: Peter Lang, 1997).

2. The amount of recent work on these subjects is immense, so I will give only a few examples. For servants and indenture, see Steinfeld, The Invention of Free Labor; David Galenson, White Servitude in Colonial America: An Economic Analysis (Cambridge: Cambridge University Press, 1981); and Northrup, Indentured Labor.

3. Pieter C. Emmer ed., Colonialism and Migration: Indentured Labor Before and After Slavery (Dordrecht, Boston, Lancaster: Martinus Nijhoff Publishers, 1986); Engerman, Terms of Labor; and Cooper, Holt, and Scott, Beyond Slavery.

4. On France, see François Régent, La France et ses esclaves (Paris: Grasset, 2007).

5. Michael Sonenscher, Work and Wages: Natural Law, Politics and the Eighteenth-century French Trades (Cambridge: Cambridge University Press, 1989); Nathalie Zemon Davis, "A Trade Union in Sixteenth-century France," Economic History Review 19 (1966): 48-69; Kaplan, La fin des corporations; and William Sewell, Gens de métier et révolution. Le langage du travail de l'Ancien régime à 1848 (Paris: Aubier, 1983).

6. Willibald Steinmetz, ed., Private Law and Social Inequality in the Industrial Age: Comparing Legal Cultures in Britain, France, Germany, and the United States (Oxford: Oxford University Press, 2000).

7. Wallerstein, Modern World-System. For a critique, see Marc Steinberg, "Capitalist Development, the Labor Process, and the Law," American Journal of Sociology 109, 2 (2003): $445-95$.

8. Among others, Steinfeld, The Invention of Free Labor; Robert Steinfeld, Coercion, Contract, and Free Labor in the Nineteenth Century (Cambridge: Cambridge University Press, 2001); Deakin and Wilkinson, The Law of the Labor Market; Hay and Craven, Masters, Servants, and Magistrates.

9. Steinfeld, The Invention of Free Labor, especially chapter 3; Michael Postan, "The Chronology of Labor Services," Transactions of the Royal Historical Society 20 (1937): 169-93.

10. Sureh Naidu, Noam Yuchtman, "How Green Was My Valley? Coercive Contract Enforcement in Nineteenth-century Britain," NBUR working papers, 2009.

11. Derek Fraser, The Evolution of the British Welfare State, 4th ed.,(London: Palgrave Macmillan, 2009), 67.

12. British Parliamentary Papers, Report from the Commissioners for Inquiring into the Administration and Practical Reform of the Poor Laws, 1834, XXVIII, appendix A.

13. David Green, "Pauper Protests: Protests and Resistance in Early Nineteenth-century London Workhouses," Social History 31, 2 (May 2006): 141.

14. Crowther, The Workhouse System, 28.

15. Green, "Pauper Protests," 137-59.

16. Felix Driver, Power and Pauperism: The Workhouse System, 1834-1884 (Cambridge: Cambridge University Press, 1993).

17. On this link, see Crowther, The Workhouse System.

18. Ann Kussmaul, Servants in Husbandry in Early Modern England (Cambridge: Cambridge University Press, 1981).

19. Steinfeld, The Invention of Free Labor, 32.

20. Postan, "The Chronology of Labor Services."

21. Crawford B. Macpherson, The Political Theory of Possessive Individualism (Oxford: Oxford University Press, 1962).

22. Peter Laslett, The World We Have Lost (New York: Metheun, 1965).

23. Steinfeld, The Invention of Free Labor, 17-22.

24. Hay and Craven, Masters, Servants, and Magistrates, 7. 
25. William Blackstone, Commentaries on the Laws of England, 4 vols. 4 volumes, (London: Strahan, Woodfall, 1793-95), booklet 2: 402.

26. George Barnsby, Social Conditions in the Black Country (Wolverhampton, England: Integrated Publishing Service, 1980).

27. Donna C. Woods, "The Operation of the Masters and Servants Act in the Black Country, 1858-1875," Midland History 7 (1982): 93-115; Mark R. Freedland, The Contract of Employment (Oxford: Oxford University Press: 1976); David Galenson, "The Rise of Free Labor: Economic Change and the Enforcement of Service Contract in England, 13611875," in Capitalism in Context: Essays on Economic Development and Cultural Change in Honor of R.M. Hartwell, ed. John James and Mark Thomas (Chicago: University of Chicago University, 1994), 114-137.

28. Christopher Frank, "Britain: The Defeat of the 1844 Master and Servants Bill," in Hay and Craven, Masters, Servants, and Magistrates, 402-21.

29. Richard Rudolph, ed., The European Peasant, Family, and Society: Historical Studies (Liverpool: Liverpool University. Press, 1995); Gay Gullickson, "Agriculture and Cottage Industry: Redefining the Causes of Proto-industrialization," The Journal of Economic History 43, 4 (1983): 831-50.

30. Douglas Hay and Nick Rogers, English Society in the Eighteenth Century: Shuttles and Swords (Oxford: Oxford University Press, 1997).

31. Hrothgar J. Habakkuk, American and British Technology in the Nineteenth Century (Cambridge: Cambridge University Press, 1962).

32. Joel Mokyr, The Lever of Riches (Oxford: Oxford University Press, 1990), 165.

33. Charles Timmer, "The Turnip, the New Husbandry, and the English Agricultural Evolution," Quarterly Journal of Economics LXXXIII (1969), 375-95.

34. George Grantham, "Agricultural Supply during the Industrial Revolution: French Evidence and European Implications," Journal of Economic History 49, 1 (1989): 43-72; Giovanni Federico, Feeding the World: An Economic History of Agriculture, 1800-2000 (Princeton: Princeton University Press, 2005).

35. Patrick O' Brien, "Agriculture and the Industrial Revolution," Economic History Review 30, 1 (1977): 166-81; Gregory Clark, "Productivity Growth without Technical Change in European Agriculture before 1850," The Journal of Economic History 47, 2 (June 1987): 419-32.

36. F. M. L. Thompson, “The Second Agricultural Revolution, 1815-1880," Economic History Review 21 (1968): 62-77.

37. Grantham, "Agricultural Supply."

38. Phyllis Deane and W. A. Coale, British Economic Growth, 1688-1959 (Cambridge: Cambridge University Press, 1962); Peter Temin, "Labor Scarcity and the Problem of American Industrial Efficiency in the 1850s," Journal of Economic History XVI (Sept. 1966): 277-98.

39. Kenneth Arrow, Henri Chenery, B. Minhas, and Robert Solow, "Capital-labor Substitution and Economic Efficiency," Review of Economics and Statistics XLIII (Aug.1961), 225-50.

40. Christine MacLeod, Inventing the Industrial Revolution (Cambridge: Cambridge University Press, 1988).

41. Charles Feinstein, "Capital Formation in Great Britain," in The Cambridge Economic History of Europe, vol. VII: The Industrial Economies: Capital, Labor, and Enterprise, ed. Peter Mathias and Michael Postan (Cambridge: Cambridge University Press 1978), 28-94.

42. Nicolas R. Crafts, British Economy during the Industrial Revolution (Oxford: Clarendon Press, 1985); Jeffrey Williamson, "Why Was British Growth So Slow during the Industrial Revolution?" Journal of Economic History 44, 3 (1984): 687-712; Charles Knick Harley, "British Industrialization before 1841: Evidence of Slower Growth during the Industrial Revolution," Journal of Economic History 42, 2 (1982): 267-89; Deane and Coale, British 
Economic Growth; Charles Feinstein and Sidney Pollard, eds., Studies in Capital Formation in the United Kingdom, 1750-1920 (Oxford: Clarendon Press, 1988).

43. Deakin and Wilkinson, The Law of the Labor Market, 20.

44. Gregory Clark, "Why Isn't the Whole World Developed? Lessons from the Cotton Mills," Journal of Economic History 45 (March 1987): 141-74.

45. Richard Biernacki, The Fabrication of Labor: Britain and Germany, 1640-1914 (Berkeley: California University Press, 1995).

46. Duncan Bythell, The Sweated Trades: Outwork in Nineteenth-century Britain (London: Batsford Academy, 1978; James Schmiechen, Sweated Industries and Sweated Labor: The London Clothing Trades, 1860-1914 (Urbana, IL: University of Illinois Press, 1982).

47. De Vries, The Industrious Revolution.

48. E. J. T. Collins, "Migrant Labor in British Agriculture in the Nineteenth Century," Economic History Review 29, 1 (1976), 38-59; Gilles Postel-Vinay, "The Dis-integration of Traditional Labor Markets in France: From Agriculture and Industry to Agriculture or Industry," in Labor Market Evolution, ed. George Grantham and Mary MacKinnon (London and New York: Routledge, 1994), 64-83. For Germany: Melton, "Population Structure," 297-324.

49. George Grantham, "Divisions of Labor: Agricultural Productivity and Occupational Specialization in Pre-industrial France," The Economic History Review 46, 3 (1993): 478-502.

50. K. D. M. Snell, "Agricultural Seasonal Unemployment, the Standard of Living, and Women's Work in the South and East, 1690-1860," The Economic History Review 34, 3 (1981): 407-37.

51. Charles Sabel, Jonathan Zeitlin, eds., World of Possibilities (Cambridge: Cambridge University Press, 1997).

52. Kenneth Sokoloff and David Dollar, "Agricultural Seasonality and the Organization of Manufacturing in Early Industrial Economies: The Contrast Between England and the United States," The Journal of Economic History 57, 2 (1997): 288-321; Maxine Berg, The Age of Manufactures, 1700-1820 (London: Routledge, 1994); George Boyer, An Economic History of the English Poor Law (Cambridge, Cambridge University Press, 1990); Simon Kuznets, Seasonal Variations in Industry and Trade (New York: NBER, 1933).

53. Postel-Vinay: "Dis-Integration."

54. Michael Huberman, "Invisible Handshakes in Lancashire: Cotton Spinning in the First Half of the Nineteenth Century," The Journal of Economic History 46, 4 (1986): 987-98.

55. Biernacki, The Fabrication of Labor.

56. Michael Huberman, Escape from the Market: Negotiating Work in Lancashire (Cambridge: Cambridge University Press, 1996).

57. Grantham, "Divisions of Labor."

58. Huberman, Escape from the Market.

59. Paul Craven and Douglas Hay, "The Criminalization of Free Labor: Masters and Servants in Comparative Perspective," Slavery and Abolition 15, 2 (1994): 71-101.

60. Gregory Clark, "Factory Discipline," The Journal of Economic History 54, 1 (1994): 128-63.

61. Judicial Statistics, England and Wales, 1857-1875, 19 vols. London, 1858-1876. Also, Steinfeld, Coercion, 73-78.

62. Douglas Hay, "England, 1562-1875: The Law and Its Uses," in Hay and Craven, Masters, Servants, and Magistrates, 67.

63. Naidu and Yuchtman, "How Green Was My Valley?"

64. Steinfeld's Coercion brings several examples.

65. Douglas Hay, "Master and Servant in England: Using the Law in the Eighteenth and Nineteenth Centuries," in Steinmetz, Private Law, 227-64.

66. For the most complete data, see Hay "England, 1562-1875," table 2.1.

67. Ibid., 93-94. 
68. Hay, "England 1562-1875," 59-116, in particular, 67.

69. Ibid.

70. Woods, "Operations," 102.

71. Naidu, Yuchtman, "How Green Was My Valley?"

72. Emile Coornaert, Les corporations en France (Paris: Gallimard, 1941); Edward P. Thompson, The Making of the English Working Class (London: Vintage Books, 1963); and Sewell, Gens de métier et révolution.

73. Sonenscher, Work and Wages; Minard, La fortune du colbertisme.

74. Alain Cottereau, "Droit et bon droit. Un droit des ouvriers instauré, puis évincé par le droit du travail, France, XIXe siècle," Annales 57, 6 (2002): 1521-57; Deakin and Wilkinson, The Law of the Labor Market.

75. Jean Domat, Les lois civiles dans leur ordre naturel, first edition 1697, reproduced in Euvres (Paris: 1835), vol. 1; and R. Pothier, Traité du contrat de louage (Paris: Bugnet, 1861).

76. Sonenscher, Work and Wages, 75.

77. "La domesticité est une sorte d'esclavage." See the Encyclopédie méthodique, vol. 9: "Jurisprudence," 15 (Paris: 1789). Sara Maza, Servants and Masters in Eighteenth-century France (Princeton: Princeton University Press, 1983); Jean-Pierre Gutton, Domestiques et serviteurs dans la France d'ancien régime (Paris: Aubier, 1981).

78. Cottereau, "Droit et bon droit."

79. Jean-Marc Moriceau, "Les Baccanals ou grèves des moissonneurs en pays de France, seconde moitié du XVIIIe siècle," in Mouvements populaires et conscience sociale, ed. Jean Nicolas (Paris: Maloine 1985), 420-33.

80. Hoffman, Growth .

81. Jean-Luc Mayaud, "Salariés agricoles et petite propriété dans la France du XIXe siècle," In La moisson des autres, ed. Jean-Claude Farcy and Ronald Hubscher (Nice: Créaphys édition, 1996): 29-56.

82. Philip Hoffman, Growth in a Traditional Society. The French Countryside, 1450-1815 (Princeton: Princeton University Press, 1996), 45-46.

83. Abbé Rozier, Cours complet d'agriculture ou Dictionnaire universel d'agriculture, vol. 8: "Domestique" (Paris: Clouzier 1789), 353. I thank Gilles Postel-Vinay for this reference.

84. Collins, "Migrant Labor"; Postel-Vinay, "The Dis-integration."

85. Rozier, Cours, 353.

86. Yvonne Crebouw, Salaires et salariés agricoles en France, des débuts de la révolution aux approches du XXe siècle (Lille: ANRT, 1986); Yvonne Crebouw, "Droit et obligations des journaliers et des domestiques, droits et obligations des maitres," in Farcy and Hubscher, La moisson, 181-200.

87. Parliamentary inquiries of 1848 (Archives Nationales, henceforth AN C, 844-858) and 1870 , in AN C 1157-61.

88. Jean Hilaire, Introduction à l'histoire du droit commerciale (Paris: LGDJ, 1986), 107-11.

89. See Usages locaux ayant force de loi dans le département de la Meuse (Bar-le-Duc: Imprimerie Contant-Laguerre, 1900); Louis Bertrand, Usages locaux du département de la Haute-Loire (Le Puy: Imprimerie de Marchesson 1865); Aimé Dumay, Usages locaux du département de la cote d'or (Dijon: Imprimerie E. Jobard 1884); Raphaël Mosse, Les usages locaux de l'arrondissement d'orange (Orange: P. Martin, 1914); J. M. P. Limon, Recueil des usages locaux en vigueur dans le Finistère (Quimper: Imprimerie de Lyon, 1852); Hyacinthe Watrin, Département de l'Eure-et-Loir: usages des quatre arrondissements et notions de droit usual (Chartres: Lester 1910).

90. AN F 121516 à 1544; AN F 10 451-2.

91. Gilles Rouet, Justice et justiciables an XIX et XX $X^{e}$ siècles (Paris: Belin, 1999).

92. In French legal and economic language, the wages of servants and servants in husbandry are called gages; this designated the monetary component of their remuneration as distinct from food and housing provisions. Thus gages are clearly distinguished from wages, which 
were given only for wage labor. It will be interesting to study when and why the English language adopted the word wages to indicate both configurations - this despite the evident legal, economic, and social differences between a domestic servant and a wage earner.

93. Jean-Claude Farcy, Guide des archives judiciaires et pénitentiaires, 1800-1958 (Paris: CNRS éditions, 1992).

94. AN F 10452 "Fixation des salaires agricoles," an II, an III; Henri Clément, Essai sur les usages locaux du Pas-de-Calais (Arras: Topino 1956); and AN C 1157-61.

95. Crebouw, "Salaires."

96. Louis Carrier de Ladeveze, Notice sur les usages locaux (Villefranche de Périgord: Dordogne, Sarlat: 1908).

97. Crebouw, "Salaires," 185.

98. Recueil des usages locaux en vigueur dans le département de la Vienne (Poitiers: Bertrand: 1865); Recueil des usages locaux du département d'Indre-et-Loire (Tours: Guiland Verger, 1863); Antoine Pages, Usages et règlements locaux, servant de complément à la loi civile et topographie légale du département de l'Isère (Grenoble: Baratier frères, 1855). See also the 1870 parliamentary enquiry in AN C 1157-61.

99. The livret ouvrier was a discharge certificate; it had to certify being hired for a specific job and its completion (quittance) or acknowledge that the worker had not yet paid off advances received as wages and that his debt remained to be deducted from future wages by the new employer.

100. AN C 846-860.

101. Crebouw, "Droit."

102. Cottereau, "Droit et bon droit."

103. Cottereau, "Droit et bon droit."

104. Alain Dewerpe, Le monde du travail en France, 1800-1950 (Paris: Colin, 1989); Yves Lequin and Pierre Delsalle, La brouette et la navette: tisserands, paysans et fabricants dans la région de Roubaix et de Tourcoing, 1800-1848 (Lille: Westhoek, 1985); and Jacques Le Goff, Du silence à la parole (Rennes: Presses Universitaires de Rennes, 2004).

105. Steinfeld, Coercion; Steinberg, "Capitalist Development," 445-95.

106. Robert Allen, Enclosures and the Yeoman (Oxford: Clarendon Press, 1992)

107. Pomeranz, The Great Divergence.

108. Robert Allen, "Tracking the Agricultural Revolution in England," Economic History Review, LII, 2 (1999): 209-235.

109. O'Brien, "Agriculture."

110. Grantham, "Agricultural Supply."

111. Federico, Feeding the World.

112. Clark, "Productivity Growth."

113. Grantham, "Agricultural Supply"; Allen, Enclosures; O’Brien, "Agriculture."

114. Thompson, "The Second Agricultural Revolution."

115. Hagen, Ordinary Prussians .

116. Ogilvie, Cerman, European Proto-industrialization.

117. Sabel and Zeitlin, World of Possibilities.

118. Postel-Vinay, "The Dis-Integration."

119. Peter Lindert and Jeffrey Williamson, "Revising England's Social Tables, 1688-1867," Explorations in Economic History 19, 4 (1982): 385-408; Peter Lindert and Jeffrey Williamson, "English Workers' Living Standards During the Industrial Revolution: A New Look," Economic History Review 36, 1 (1983): 1-25.

120. Pomeranz, The Great Divergence.

121. Cerman, Ogilvie, European. 


\section{BONdAge ACROSS THE OCEAN} Indentured Labor in the Indian Ocean

\section{The Main Argument}

We have already discussed the link between labor in Europe, slavery in the colonies, and serfdom in Russia, in eighteenth- and nineteenth-century European thought (in chapter 1). Yet this was not simply a representation of the facts, but a reflection on real entanglements in social and economic relationships between Russia, Europe, and Europe's main colonies. As I mentioned in the introduction, Russian serfdom can hardly been compared to American slavery. Nevertheless, the evolution of labor in Russia and in some European colonies did reflect similar tensions. This chapter argues that not only was the definition and practice of bonded labor in the colonies linked to the definition and practice of wage labor in Europe, but that the development of labor in the two realms was interconnected. Indentured servants in the British Empire and engagés (equivalent to indentured servants) in the French colonies would have been inconceivable without hiring for services and domestic service in Britain and France. A connection was possible because there were important differences in status between masters, landowners, and employers, on the one hand, and domestic servants, wage earners, bonded laborers, and apprentices, on the other. ${ }^{1}$

Yet the British and the French did not export just any notion and practice of wage earner, but a specific form of it, that is, indentured labor. This peculiar contract derived from two types of extant contracts: that of the sailor and that of the agrarian laborer. The interaction among the forms of bondage and the notions of indenture and engagement exported by the Europeans make this an interesting case. ${ }^{2}$ 
In this context, Réunion and Mauritius Islands, along with certain parts of the Swahili coast, constitute an exception in the Indian Ocean region, insofar as they were the only areas that developed plantation economies; however, the passage from slavery to indentured labor acquired certain peculiar features that distinguished it from labor in the Antilles and the rest of the West Indies. I will use the extreme case of Réunion and Mauritius Islands to raise doubts regarding the validity of the "colonial paradigm" in general and labor questions in particular. Before looking at indentured labor, I will first briefly sketch the history of slavery in the Indian Ocean. A full development of this topic would require a book of its own and goes beyond the scope of the present study.

\section{Forms of Bondage in the Indian Ocean}

Histories of slavery in the Indian Ocean are strongly influenced by the Atlantic perspective: this means that most studies focus on the eighteenth and nineteenth centuries, on plantations on the east coast of Africa and Mauritius and Réunion Islands, and on the African labor force. ${ }^{3}$ This approach is misleading; indeed, the meaning of slavery in the Indian Ocean only becomes intelligible when viewed outside the categories of ancient or North American slavery. It often entailed mutual forms of dependence in which one individual (or a group or caste) of inferior status was obligated to another with superior status, who (or which) in turn was under obligation to his (or its) superior. Consequently, the forms of status obligation, bondage, and temporary slavery (for debt, etc.) coexisted with forms of hereditary slavery. ${ }^{4}$

Two basic systems of Indian Ocean slavery can be distinguished. The open system of slavery was found in the commercialized, cosmopolitan cities of Southeast Asia and elsewhere, where the boundary between slavery and other forms of bondage was porous and indistinct, and upward mobility was possible. In the closed systems of South (and East) Asia, the stigma of slavery made it inconceivable for a slave to be accepted into the kinship systems of their owners as long as they remained slaves; instead they were maintained as separate ethnic groups. ${ }^{5}$ Slave occupations in the Indian Ocean were diverse and varied according to location: most slaves were employed in homes as domestic servants or in construction work; in food cultivation and animal herding; as sailors and fishermen; or in artisanal occupations, ranging from distilling to saltpeter manufacturing. In port towns like Batavia and Malacca, thousands worked in docks and shipyards, loading, unloading, repairing, and servicing company vessels. ${ }^{6}$ The majority of people entered (involuntary) slavery through debt, which 
differed from debt bondage (which was mostly voluntary and exerted on collateral).

Furthermore, the chronology of slavery in the Indian Ocean differs greatly from that in the Atlantic: it was not restricted to African or nonwhite slavery and was not exclusively linked to the colonial plantation system. Quite the contrary, forms of bondage and slavery in the Indian Ocean developed over millennia, before the arrival of the European powers; it mostly concerned women and children, and with the exception of Omani plantations in East Africa and on Mauritius and Réunion Islands, it was not linked to the plantation system. Thus recent analyses identify three main peaks in the long trend of slavery in the Indian Ocean: the first, ca. $200 \mathrm{BC}-200 \mathrm{AD}$; the second, ca. 800-1300 AD; and the third, ca. 1780-1910. ${ }^{7}$ The demand for slaves was linked to rising economic cycles, mostly in labor-intensive economies, while slave supplies increased with hostile climatic conditions and degradation, as well as with the incidence of warfare and kidnapping. Thus the first cycle was linked to the expansion of ancient economies, the second to the rise of Islam, and the third to European expansion. The predominance of women and children was particularly evident in the first two cycles, but it was still important in the eighteenth century. ${ }^{8}$ Since the eighth century, Islam played a major role in connecting Eastern Africa to India and to the Arabian or Persian Gulf. ${ }^{9}$ Between the seventh and the fifteenth centuries, 3.8 million slaves were traded across the Sahara and another 2 million across the Indian Ocean. ${ }^{10}$ While demand from the world of Islam was not always responsible for the Indian Ocean trade (some slaves went to the Mascarenes, Hindu India, China, and Southeast Asia), most slaves from about $1000 \mathrm{AD}$ to the end of the trade were conveyed across the Sahara Desert and the Indian Ocean by Muslim merchants, marketed to Muslims, and employed in societies where Islam was a key force. Large units of government slaves ( $k u l)$ defied the slaveholding norm, particularly in the servile armies that supported central governments from Morocco to Mogul India. Yet agricultural slaves were not rare: during the eleventh century, up to 30,000 African slaves were employed in agricultural pursuits along the coast of what is now Bahrain. Women were an important component of the slave trade. The laws and customs relating to slavery as interpreted from the Koran produced analogous results in lands as dispersed as the Hejaz, the Maghreb, Oman, the Persian Gulf, and north India. In all these regions, slave women were prized by freemen as wives and concubines, while free women sought female slaves as attendants and household laborers. ${ }^{11}$

This system did not end after the seventeenth century with the arrival of the European powers, which competed with these already existing 
networks and eventually integrated them. ${ }^{12}$ Thus the Omanis enhanced their power in the western Indian Ocean by founding colonies in Zanzibar and Kilwa. Traditional imports of domestic slaves to Arabia added to the increasing slave trade between inland Africa and the Omanis plantations along its east coast. ${ }^{13}$ In the Mozambique Channel since the seventeenth century, the expanding slave trade was linked to the immigration of Swahili and Hadrami Arabs to the region and the exportation of labor from northwest Madagascar to the ports of the Swahili coast and Arabia that reached its heyday in the seventeenth and early eighteenth centuries. From the middle of the eighteenth century, however, developments in both the interior of Madagascar (the rise of the Imerina Empire) and along the Swahili coast caused a shift in the trade, so that Madagascar became a significant importer of bonded African labor from Mozambique. ${ }^{14}$

In Madagascar, the Antalaotras-Islamic merchants of Swahili-Arab origin-controlled the slave as well as the general trade with the Arabian Peninsula. They constituted a powerful network with the Indians Karany (Muslims) in Merina and with the Omani power in Zanzibar. ${ }^{15}$ The Swahilis themselves took an active part in the commerce in ivory and slaves. ${ }^{16}$ Instead of making an attempt to seize control of the trade, the European powers—-the Portuguese, ${ }^{17}$ Dutch, ${ }^{18}$ British, ${ }^{19}$ and French ${ }^{20}$ — thus sought to integrate the already existing networks.

The role of non-European merchants is even more important if we do not limit ourselves to the maritime, but consider also the overland slave trade. Thus between 1400 and 1900, 2.5 million slaves were traded by sea along the coast of the Indian Ocean, while about 9 million passed along the trans-Saharan route (3.6 million being exported) ${ }^{21}$ Exports of slaves from East Africa rose from 100,000 in the seventeenth century to 400,000 in the eighteenth century and $1,618,000$ in the nineteenth century, half of whom were sent overseas and the other half of which was retained on the eastern African coasts. ${ }^{22}$ In all the areas concerned, in Africa as in India, in Arabia as in Europe, the increasing demand for labor was linked to the general upward economic trend. Not only the European empires, but also the Omani, Merina, Ethiopian, and Egyptian Empires, developed and required a larger labor force. As in earlier times, concubines, soldiers, domestics, and plantation slaves formed the bulk of this trade. Pearl fishers in the Gulf, slave-seamen, and new urban slaves were also important. ${ }^{23}$ The European demand for sugar and cotton strongly contributed to the growth of the slave trade in the Indian Ocean: the Mascarene Islands absorbed most of the slave trade, while, paradoxically, the abolition of slavery in the United States led to increasing production of cotton in Egypt, which greatly relied on slaves. ${ }^{24}$ 
As a consequence of this, when the British decided to abolish the slave trade, they had to compete not only with recalcitrant French and Portuguese, but also with local powers and existing forms of bondage. The issue of this confrontation was even more complicated by the fact that the European powers, including the British, did not always have a clear-cut distinction between free and unfree labor.

\section{Forced Migration Across the Oceans: Convicts}

Even if engagisme (in the French Empire) and indentured (its equivalent in the British Empire) labor mostly developed after the abolition of slavery, as a temporary solution to the lack of labor on the plantation, the end of slavery cannot fully explain their development entirely. Indeed, these forms of labor were used before slavery; they were not only linked to the plantation economy-like slavery itself in the Indian Ocean-and they persisted long after the abolition of slavery and the decline of the plantation system. To understand indentured labor, we thus need to keep in mind both the multiple versions of bonded labor in the Indian Ocean and the peculiar notions and practices of labor that the Europeans sought to export into this area-to start with, convict labor.

Convict labor as a form of penal servitude is usually associated with public law and social order. ${ }^{25}$ Yet its boundary with private law and private forms of servitudes was continuously blurred. Convicts transported by the British to North America, the Caribbean, Australia, or the Indian Ocean in the seventeenth and eighteenth centuries were given in service to private merchants and estate owners. The terms of service were often between seven and fourteen years, with no guarantee that the convict would be redeemed at the end of the term. Since the 1830s, the abolitionist movement began to include convict labor among the forms of labor it regarded as slavery. The lack of convicts' consent to the duration of work and the price were arguments in favor of this orientation; defenders of the convict system argued that unlike slavery, penal servitude was not perpetual; it rested upon conviction; and it lacked any racial basis. Indeed, the living conditions of convicts depended on the time, the colony, and the estate. In public camps, the inmates were subjected to severe deprivation, while when assigned to private merchants or planters, they were quickly assimilated to slaves and thus often protected as a form of capital (for example, in Australia). At the same time, private masters did not hesitate to punish convicts for disobedience. Convict labor was often made up of prisoners who had previously been condemned to death but whose sentences had been commuted to lifetime penal servitude; however, in 
periods of rigorous enforcement of the law in Britain coupled with the inadequacy of the country's prisons to cope with the number of prisoners, many people were transferred to labor for minor offences. Something like 60,000 British convicts were transported to North America and the Caribbean between the 1660s and the 1770s, and 162,000 were sent to Australia between 1788 and 1867. ${ }^{26}$ The French transported at about 36,000 convicts to French Guiana and New Caledonia. To this, one has to add at least 100,000 Indian convicts transported to Aden, Mauritius, and Southeast Asia, between the 1790s and the early 1860s. ${ }^{27}$

Convict labor was unpaid but costly; the costs of transportation, feeding, and surveillance had to be taken into consideration, and they often exceeded the estimated or real monetary rewards. ${ }^{28}$ Convicts also frequently escaped-some 9 percent did so in Maryland between 1746 and 1775-and were often drunk and incapable of work. ${ }^{29}$ At the same time, convict labor cannot be evaluated solely on the basis of a cost-benefit analysis that compares it with wage labor. In the places where convict labor was primarily used in the seventeenth and eighteenth centuries, there was extremely little or no free labor. When the conditions in new settlement colonies were too harsh to attract free labor, convicts were pressed into the breach. Clearance of the land, the construction of harbors and roads, and the development of cattle and sheep ranches were among the convicts' tasks. They also exploited timber and minerals where the climate and the terrain were so hostile that compulsion remained the only viable solution. In the seventeenth and early eighteenth century, petitions by convicts show that they still preferred to serve in the army, be flogged, or used for medical research rather than be transported to America. ${ }^{30}$ From this standpoint, convict labor aimed at a goal similar to that of the workhouse; beyond any calculation of utility and economic considerations, these forms of bondage served multiple aims, such as meting out punishment and providing a labor force for situations in which other forms of more or less coerced labor (indentured immigrants) were still insufficient and where slave imports were still too expensive. With this background one can understand the indirect benefit Britain sought to gain by sending convicts to Australia: by doing so they reduced incarceration costs and the rate of recidivism (which was 80 percent for the incarcerated population in question), while engaging in a positive production of wealth. ${ }^{31}$ This calculation was probably accurate for Australia and some areas of North America, but much less for Guiana and the Indian Ocean settlements. The latter case involved Indians and other Southeast Asian populations, unlike the first generation of convicts sent to Australia, who were white convicts unacceptable in the motherland. Britain began to send Indian convicts to Mauritius from the turn of the 
eighteenth century to the nineteenth century. Yet within a few years, the authorities expressed increasing skepticism about the efficiency of convict labor, focusing in particular on the high cost of convict transportation. Other considerations pushed in the opposite direction, namely the lack of labor force in Mauritius and other British settlements in Southeast Asia after the abolition of slavery, as well as the perception that convict transport was an appropriate punishment in India's caste-based society. ${ }^{32}$ But the issue on the ground was quite different: members of high castes were extremely rare among convicts, most of whom were peasants, of low castes, or even Muslim. Most of them were placed under colonial authorities for public works. However, convicts enjoyed a limited right to move, and some of them had children. They entered into economic relations, which raised the question whether they could actually own property. ${ }^{33}$ Colonial authorities mostly answered this question in the affirmative. ${ }^{34}$ Between 1815 and 1837, almost 1,500 Indian convicts were transported to Mauritius, first from Bengal, then from Bombay. Even if their legal status was not that of formal slaves, their very existence raised the question of the boundary between forms of servitude within empires and, thus, that of the boundary between bondage and formally free labor. In the next section we will study the evolution of indentured immigration in the Indian Ocean before, during, and after slavery. ${ }^{35}$

\section{The Invention of Engagisme}

Engagisme has received less attention than either Anglo-Saxon indentured service or slavery in the strict sense. One of the rare works devoted to French engagisme was undertaken by Gabriel Debien, who combed the notary archives in Normandy and Brittany as well as archives in the French West Indies. ${ }^{36}$ Louise Dechêne ${ }^{37}$ also discussed certain aspects of white engagisme in Canada, in a work later summarized by Fréderic Mauro. ${ }^{38}$

In the French colonies, the contract of engagement or indentured service was developed in the seventeenth century. It was initially intended for white settlers whose transport expenses were advanced by employers or their middlemen in exchange for a commitment to work for several years. The engagés were subject to criminal penalties and could be transferred along with their contract to other masters. Owing to the close resemblance between wage earners and domestic servants (especially under the ancien régime) and the survival of forms of domestic service into the nineteenth century, the contract of engagement should not be understood in opposition to these other labor relationships, but rather as an extension and of them in the colonial situation. In other 
words, whereas our own accustomed categories contrast free wage work in France with slavery and indentured service in its colonies, the actors at the time regarded the contract of engagement as a free contract, and the penalties for breach of contract were quite similar to those applied to laborers. Indeed, the notaries of Normandy in charge of drafting the first contracts of engagement in the seventeenth century explicitly relied on two types of contracts that already existed: the agricultural journeyman's contract and the sailor's contract. These contracts provided for a particular status of the hired person who offered his services and all his time to his master. The agricultural journeyman transferred exclusive ownership of his time and services to his employer; the sailor's contract extended the duration of this sale with special clauses related to voyage expenses. As Debien noted, these contracts "are reminiscent of contracts to farm uncultivated land in France, and the ties between the first engagés and their masters were rather like those between tenant farmers and our rural domains. The oldest contracts of engagement were thus the ones that still had some connection to rent paid by tenants to feudal lords and leases for tenant farming." ${ }^{39}$ It is no accident that contracts of engagement explicitly mention hiring for service: the engagé rented his services, i.e., the totality of his time, to his master, and terminating a contract was difficult, especially for the engagé ${ }^{40}$ Similarly, contracts of engagement explicitly invoked apprenticeship contracts: the master had the same requirement to provide for the care of the engagé as he did for the apprentice, the same expenses in case of illness, and the same word in the margins: bondage. ${ }^{41}$

However, two clauses differentiated the apprenticeship contract from the contract of engagement: the act of apprenticeship emphasized training in a trade, whereas in the contract of engagement, the engagé first owed his labor to his master who, in exchange, was to teach him about colonial farming. It was also the master who gave a lump sum to his engagé and not the other way around, as in the case of the apprentice. ${ }^{42}$

Sometimes the close relationship between engagement and apprenticeship was explicit, and the expression engagement-apprentissage appeared. In this case, the engagé departed and returned with his master to work on all "his affairs, trade, and commerce." These engagés were not apprentice-settlers but apprentice-merchants, without wages. Indeed, the father or mother of the engagé paid a lump sum to the merchant or the settler. ${ }^{43}$ The overwhelming majority of the contracts studied by Debien concern fatherless engagés. And finally, the contract of engagement also borrowed from the sailor's contract in that it clearly stipulated the length and type of service required and, above all, the penalty for desertion. ${ }^{44}$

Sometimes the engagement involved a contract of association between two engagés or between an engagé and the captain of a ship. In the second 
case, the engagé offered his service to the captain, who covered the cost of passage. Once they arrived, the captain could sell the engagé and his debt to a master or share the labor services (or the income generated from them) with this master. In the case of association, on the other hand, the two engagés shared the capital and the labor; they called each other "my mate," with the association usually, but not necessarily, ending when one of the associates married. ${ }^{45}$ In general the engagés were not allowed to marry without authorization from the master, but an engagé had the right to redeem his indenture and could oblige his master to agree to do so. Differences nevertheless appear in this overall context between the engagés "with no trade" and those who left as doctors, carpenters, etc. The latter committed themselves for three years instead of five; they received wages but were not subject to the servitude clauses imposed on the others.

Finally, in addition to the trade involved, our understanding of contracts of engagement should be qualified in accordance with the destination (French West Indies, Canada, or the Indian Ocean) and the historical period. In the seventeenth and eighteenth centuries, the contract of engagement concerned mainly whites who went to the French West Indies and Canada, but also to the Indian Ocean. ${ }^{46}$ Between 1660 and 1715, 5,200 engagés left for the French West Indies from La Rochelle alone. This figure is much smaller than the 210,000 indentured Britons who left for North America between 1630 and $1700 .{ }^{47}$

\section{Engagés from Asia and Africa in the Indian Ocean in the Eighteenth and Nineteenth Centuries}

Many scholars assert that white engagisme can be situated in the initial colonial context, i.e., prior to the rapid development of plantations, when the practice was to use non-white slaves. This interpretation, while not incorrect, must be qualified; in fact, engagisme did not disappear with slavery but continued during and, most of all, after it. It is important to account for how legal institutions were passed on, how they were applied to whites and people of color, and the economic significance of engagisme. Indeed, the Mascarene Islands were an exception insofar as they were the only ones to develop a plantation economy and forms of slavery similar to North American slavery, this dominating other forms of dependence. ${ }^{48}$ On Réunion Island, alongside the use of slaves in the strictest sense, ${ }^{49}$ engagés of color were employed in the eighteenth century and even more so in the nineteenth. This immigration was partly linked to the need for artisans (Indian carpenters and masons), but above all to the demand for additional laborers at a time when, under pressure from the English, the 
price of slaves was constantly rising and rumors of the abolition of slavery in France and its colonies were growing. ${ }^{50}$ In all, about 160,000 slaves are estimated to have been imported to the Mascarene Islands prior to $1810 .{ }^{51}$ They came primarily from Madagascar ( 70 percent), followed by Mozambique and East Africa (19 percent). ${ }^{52}$ In the early eighteenth century, France played a central role in organizing the slave trade in East Africa that was intended for the Mascarene Islands. ${ }^{53}$

After the Napoleonic Wars, although France officially reintroduced slavery, English pressure resulted in certain slave importations assuming the form of contracts of engagement. In this manner, an estimated 45,000 illicit slaves were imported to Réunion Island between 1817 and $1835 .{ }^{54}$ Taking into account official censuses and disguised importations, between 48,900 and 66,400 slaves are believed to have arrived in Réunion between 1811 and 1848. According to Allen, about 300,000 slaves were imported to the Mascarene archipelago between the eighteenth and the first half of the nineteenth century. Unlike the trend during the eighteenth century, this time East Africa and Mozambique were the main source of supply (60 percent), with the rest coming from Madagascar ( 31 percent) and the countries of southern Asia (9 percent). ${ }^{55}$ These networks, as we shall see, were to remain in place after the abolition of slavery.

Under these conditions, the distinction between slave and engagé was difficult to determine. The fragile dividing line was noticeable when they departed and when they arrived. A ship's captain transporting Indians to Réunion Island would often resort to fraud; contracts of engagement to Singapore were signed, but the engagés ended up being sent to Réunion. ${ }^{56}$

Once arriving on Réunion Island, there was no legal or factual dividing line between engagement and slavery. The reports drafted by the interior director and the governor, as well as correspondence with the ministries concerned at the time, manifestly show that the French colonial administration not only encouraged the Indian engagés and tried to establish rules of law that were sufficiently clear to avoid trouble, but that they were also concerned with actual enforcement of these laws. ${ }^{57}$ These attitudes intersected with those of the abolitionist movement: some English administrators considered the "liberation" of labor a sign of real progress not only from an economic standpoint, but also in a political and moral sense. ${ }^{58}$ All the same, translating these principles into action remained difficult. During the first half of 1830, Indian engagés numbered about $3,000 .{ }^{59}$ The legal rules in force provided that the engagés should receive food, lodging, and wages. ${ }^{60}$ In practice, however, the employer-landowners seldom complied with the rules, and in the event of a dispute or a problem with the administration, the settlers justified withholding the wages of the Indian engagés by claiming that they had failed to fulfill 
their commitments. The arguments invoked were quite similar to those used with regard to the labor of domestic servants in France at end of the nineteenth century.

Does this mean that rules of law had no impact and consequently that there was no real distinction between the conditions of these engagés and those of real slaves?

The bonded servants and engagés did have rights, however much they may have been flouted. How those rights were secured depended not only on the wording of the laws but also on enforcement procedures (e.g., burden of proof, a method of written and oral evidence that radically shifted the weight of possible intimidations). Although domestic servants in France also lived in a state of inequality in relation to their masters, they nevertheless enjoyed the support of justices of the peace, an advantage that Indian engagés lacked on Réunion Island. However, the situation of the latter group was less dramatic than that of real slaves. Indeed, the engagés resisted not only by fleeing (runaways), reducing their labor, and rioting, but also by multiplying their lawsuits, which were undoubtedly more frequent than those of slaves during the same period. ${ }^{61}$ Faced with the unfavorable attitude of the magistrates and the administration, Indian engagés formed a trade union in which the members with the best mastery of the French language played a highly active role in formulating appeals, intervening with the authorities, etc. ${ }^{62}$ Some trials resulted in favorable decisions for the Indians, who were then able to recover their wages or leave without having to pay compensation to their masters. Debates arose among the settlers, and rumors spread of increasing appeals by the engagés that would inevitably lead to the breakdown of the whole social order. In 1837, the trade union was prohibited. ${ }^{63}$

At this point, the engagés, like agricultural wage earners in France, discovered another weapon: competition among employers. If they did not like their working conditions, they simply left their employers and went into the city, where they worked as domestic servants. They became "fugitives" and "deserters",64 the use of these terms in ordinary as well as legal language of the time clearly conveys the link between white engagés and soldiers, on the one hand, and runaway slaves on the other. More concretely, many landowners did not demand the return of their runaway engagés; they knew perfectly well that it was in the interest of many of them to appropriate engagés or even slaves belonging to other settlers. This opportunistic behavior was prompted by various motives: some could not afford to buy slaves; others, including some of the large plantation owners, offered better conditions than small landowners, thereby helping to crush the small landowners in a process ranging from unfair competition (as described by the law) in the area of slavery and 
engagement to the abolition of slavery, which was decidedly favorable to large landowners. ${ }^{65}$ Yet the lack of cooperative agreements between estate owners opened up the possibility for workers to move from one estate to another while benefiting from their new master's protection.

Competition between planters and estate owners reinforced the immigrants' resistance, but so did the different attitudes among colonial rulers. Some rulers, such as Governor Pujol, requested legal protections for immigrants like those already in place in Mauritius; ${ }^{66}$ other colonial administrators and plantation owners thought this state of affairs was due to Indian indolence rather than to contracts of engagement and lack of cooperation among landowners. Other solutions were then considered, starting with the importation of Chinese engagés. A new decree was adopted in 1843 to regulate these engagés: their contracts were supposed to last at least five years, and the minimum age of the engagé was set at sixteen; the landowners had to agree to pay wages and the return trip to China; ill treatment or a two-month delay in wage payments was sufficient grounds for the administration to nullify a contract. ${ }^{67}$ By tightening the legal rules in favor of the engagés, the administration hoped to solve the problem of labor shortage and the social issues raised by the Indian engagés. However, once again, estate owners seemed unwilling to comply with the rules. ${ }^{68}$ As a result, the few dozen Chinese who arrived soon adopted the same attitude as the Indians: they protested against their living conditions and overdue wages; they started legal proceedings or left their employers. ${ }^{69}$ Thus, barely three years after the decree regulating the importation of Chinese engagés, a new decree was issued prohibiting Chinese engagés, who were now seen as troublemakers. ${ }^{70}$ It was in this context that slavery was abolished in France and its colonies. Did this step mark a new departure, or did it simply consolidate existing practices under a new name?

\section{Engagisme after Slavery}

In 1847 there were a total of 6,508 engagés-Indians, Chinese, Africans, and Creoles combined. ${ }^{71}$ The lack of available labor encouraged several landowners to call for the arrival of additional engagés, but this time from Africa, especially since France was moving toward the abolition of slavery. Indeed, as in the British Empire in the 1830s and 1840s, the abolition of slavery in the French colonies in 1848 was followed by a revival of engagés. While only 153 African engagés entered into service in 1853, thereafter, on average, about 4,000 Africans were imported each year between 1851 and 1854; 10,008 were imported in 1858 and 5,027 the following year. ${ }^{72}$ In reality, recruitment in India, Madagascar, Mozambique, and 
the eastern coast of Africa relied on networks that had been in place since the eighteenth century, and it employed the same practices as the slave trade. It often took place violently, sometimes with the help of local tribal chiefs. ${ }^{73}$ The annexation of Mayotte in 1841 opened up new sources of laborers in the Comoros Islands themselves, as well as in Madagascar and the East African coast. Using the slave-trade system already developed in the region with the rise of Islam, French traders, helped by local sultans, began importing engagés from Gabon, Congo, and West Africa. ${ }^{74}$

Between 1856 and 1866, some 8,000 engagés, almost all of them from Mozambique, passed through Mayotte on their way to Réunion Island. ${ }^{75}$ In 1853, France built new centers in Gabon and Senegal to buy engagés. There were also "prior redemptions" (the term given to such purchases) in Madagascar, Zanzibar, and Mozambique, causing conflicts with the Portuguese and the English; officially, the disputes were over the protection of engagé rights, but in reality the issue was one of controlling and dividing up the workforce among the respective empires.

Similar trends were in play in relation to Indian engagés, who were in principle under the surveillance of the British administration; in practice, however, the kidnapping of adults was regularly denounced. ${ }^{76}$ In all, 43,958 Indian engagés would arrive on Réunion Island between 1849 and $1859 .{ }^{77}$

France officially abolished these purchases in Madagascar at the end of the 1880s; however, not only did they continue, but the shortage of laborers was so great on Réunion Island that France decided to annex Madagascar specifically to meet the demand. ${ }^{78}$ A secret agreement was signed between France and Portugal in 1887 and again in 1889, with Réunion Island becoming one of the accepted destinations for engagés from East Africa and Madagascar.

Thus the market for engagés was far from free, not only because of diplomatic and political interference, but also because of the way it worked. Whereas the rules adopted in France were increasingly favorable to workers in the early 1850s (e.g. the law prohibiting child labor, the abolition of a criminal charge for forming workers' coalitions), the Second Empire imposed tighter restrictions on emancipated slaves and engagés. A contract of engagement was imposed on all workers in the colonies; the legal rules governing the livret ouvrier were widely implemented and enforced. ${ }^{79}$ Anyone without fixed employment (defined as a job lasting more than one year) was considered a vagrant and punished as such. ${ }^{80}$ The penalties were considerable, but the law was also frequently circumvented through fictitious contracts of engagements that some-especially women-signed with landowners who were interested in having occasional laborers. ${ }^{81}$ 
In principle, engagés had the right to go to court and denounce cases of mistreatment and abuse. We have seen that under slavery, those rights had been largely ignored. Abolition did not much change those attitudes; in practice, it was extremely difficult to make use of the rules, above all, because colonial law courts were in the hands of local elites. Thus when immigrants addressed courts to denounce abuses, they were often sent back to their employer, who, at best, punished them and docked their wages for insubordination; in the worst case, the employer would sue them for breach of contract and slander. In the face of these difficulties, workers sometimes joined together to denounce illegal practices, but they risked being sentenced by the judge and the police to two months of forced labor in a workhouse for illicit association and breach of the peace. ${ }^{82}$

Following protests by Indian immigrants and British consuls, in the late $1850 \mathrm{~s}$ a union for the protection of immigrants was permitted. It was granted the authority to inspect estates and was supposed to offer legal protection to immigrants. However, the union performed its mission poorly, at least until the late 1860s; inspections were seldom held, and legal assistance was offered only to those immigrants who had completed less than five years of a renewed contract. This approach provoked a counter reaction on the part of immigrants and the British consul, but the initial decisions of the courts validated the conservative interpretation and rejected claims denouncing unequal treatment under the law. ${ }^{83}$

The legal disputes mainly concerned health care, contractual performance, and physical violence. Until adoption of the 1898 law on labor accidents, French employers were not held responsible for the injuries of their workers, except in cases in which they were proven to be at fault. In hiring-for-service contracts, this attitude was justified by the fact that day laborers were under short-term informal contracts. As for louage d'ouvrage, workers were considered independent artisans and as such were personally responsible for any injuries and casualties they suffered. Finally, servants in husbandry had severe constraints placed on their mobility, but at least they benefited from health care. In the colonies, indentured immigrants under the concessionary regime were immediately assimilated as servants in husbandry and were therefore supposed to benefit from health care provided by their employer; statutes and contracts explicitly provided for this obligation.

This solution was adopted within the context of broader agreements with Britain on the circulation of labor in the Indian Ocean region. Britain demanded the provision of health care on plantations in exchange for liberalizing Indian immigration to Réunion Island; however, on Réunion Island, other official provisions added that workers would benefit from 
health care only if they could demonstrate that they had complied with all the health and technical prescriptions detailed in the estate regulations and official statutes.$^{84}$ In practice, health care provision was poor; medical services simply did not exist on plantations, and injured and sick workers were not only mistreated, their wages were even reduced. ${ }^{85}$

And what about broader legal protections for immigrants?

Summaries of judicial statistics on Réunion Island are not available. We must rely on detailed archival cases and monthly reports made by justices of the peace and appeals courts. Contract renewals, wage payments, and corporal punishment were the most common issues in the lawsuits filed by engagés. Unlike slaves, engagés had the right to return home; terms were negotiated in the contract, which was supposed to comply with general provisions of the law. In practice, however, repatriation was difficult. During the 1850s and 1860s, one-third of the indentured immigrants returned home (mostly Indians). This percentage was close to that in Mauritius, the Caribbean, Surinam, and Jamaica, at the time, but it was far from the 70 percent repatriation recorded in Thailand, Malaya, and Melanesia. Distance and the cost of transport were only two of the variables affecting repatriation; politics and concrete forms of integration were also important factors. ${ }^{86}$ On Réunion Island, in particular, urban traders and certain colonial officers encouraged engagés to return home. The former group argued that once the immigrants had completed their commitment, they then settled in towns and engaged in illegal trade and unfair competition. Colonial administrators were inclined to support this view: the defense of public order required the repatriation of immigrants. ${ }^{87}$

In contrast, several employers and estate owners, especially small ones, were hostile to the resettlement of immigrants in town or their repatriation, and they pushed for the renewal of contracts. Their attitude can be explained by the fact that unlike large estate owners, they faced increasing problems finding the financial resources, networks, and diplomatic support for new recruits. They therefore made use of every legal and illegal means to retain workers at the end of their contracts. In particular, they seized immigrants' wages and livrets and added severe penalties whenever possible ("laziness" and failure to accomplish assigned tasks in due time were the most common arguments for applying penalties). Hence, the worker's "debt" was never repaid, and the contract was protracted. Day-labor standards and objectives were gradually raised so that few workers could meet them; they were thus subject to stiff penalties while working eighteen to twenty hours a day instead of the ten mentioned in contracts and official rules. ${ }^{88}$ And if all this were not enough, employers did not hesitate to use physical force to make workers renew their commitments. 
These practices had been informally denounced since the 1850 s, but it was not until the 1860s that they were brought before the courts, under pressure from British diplomats and French central government authorities. ${ }^{89}$ Even then, lawsuits often dragged on for years and involved only a very small percentage of workers. At a time when there were several thousand workers on the island, local court records list only a few dozen cases of contractual abuses and illegal wage retention per year. Even in these few cases, employers were merely forced to pay their workers due wages, with no damages or interest, though many immigrants were also granted permission to terminate (illegal) contracts and abuses without paying penalties. ${ }^{90}$

Aside from contracts and wages, corporal punishment and violence were the most common crimes brought before magistrates. In the late 1860s and 1870s, special investigative commissions were set up, most often in response to British diplomatic pressure. Their archives testify to widespread corporal punishment-but also to the resistance by members of the commission to acknowledging its existence. In most cases, abuses were described as "exceptional," though in fact they were commonplace-even in the case of the death of brutalized workers, employers were only sentenced to one month of prison. ${ }^{91}$ In first-level courts throughout the 1870s, only between one and seven employers were sentenced each year for inflicting injuries and other violence. At the appeals court level, the figure dipped to one per year, the sole exception being four individuals convicted in 1875 , but this was a single lawsuit and the three people receiving sentences were themselves immigrants working as supervisors. ${ }^{92}$

On the other side of things, every year employers sued several hundred workers for breach of contract. Sentences were usually favorable to the plaintiffs, and the workers had to face severe monetary penalties, which often translated into forced labor. Every year, immigrants were also dragged into court for robbery, for which the sentences were very tough-e.g., five years of forced labor for a stolen chicken..$^{93}$

Theft was mentioned in one case in which Chinese coolies were sued after refusing to allow their employer to "safeguard" their savings. The police confirmed that they had found an "unjustified" amount of money in their barracks; the coolies claimed it was their savings, with the employer claiming it belonged to him. The coolies were sentenced to five to seven years of forced labor. ${ }^{94}$

In sum, after the abolition of slavery on Réunion Island, access to justice was extremely limited for immigrants, and their living conditions were incredibly harsh. Legal redress for laborers and their employers 
was unequal; the abuses, corruption, or simply partisan attitudes of local officers extremely widespread. Yet engagés were not slaves, and the differences became more pronounced over time. This was due to several factors, not least of which was the persistence of the immigrants themselves, who continued to denounce abuses despite the difficulties they faced in doing so and their engaging in passive resistance, as well as absconding and forming groups and pursuing lawsuits through the courts. These approaches met with increasing "benevolence" on the part of colonial elites, in some instances because the latter firmly believed in freedom and/or the virtues of the free market and in other cases, in response to political pressure from Paris and London. Britain was doubtless inclined to protect Indian immigrants on Réunion Island not only for humanitarian reasons, but also to guarantee a labor force for British employers in India and other parts of the empire. Whatever the rationale for Britain's action (likely a combination of both motives), the final outcome was increased legal protection for immigrants. Unfair competition between small and large estate owners and between rural and urban masters on Réunion Island were also contributing factors. Major employers were much more favorable than small ones to a fair labor market insofar as they benefited from economies of scale in the recruitment and exploitation of workers.

A third factor affecting immigrant conditions was the decline of sugar prices on the international market. In the early 1840s, the average producer price of sugar was some 39 English pounds a ton. By the 1870s, it was 22 pounds a ton and, as the glut grew in the 1890s, it fell by 12 pounds, reaching a low 9.60 pounds in $1896 .{ }^{95}$ Small producers tried to cope with this trend by imposing increasingly harsh labor conditions, which provoked massive absconding (actually transfer to large estates) and worker resistance. Many petits blancs sold their properties and moved to the highlands, ${ }^{96}$ where they were joined by immigrants and former slaves who began buying land or more often cultivating it under new forms of renting. ${ }^{97}$

We still have to determine whether the case of France and Réunion Island was an exception. Did the status of engagés of color reflect a long, arduous process of abolishing slavery in France compared with Great Britain? ${ }^{98}$ And was the inferior status of immigrants in the colonies and of daily laborers and servants in France a broader consequence of the way the revolution of 1789 dealt with labor and rights?

To answer these questions, we need to compare labor conditions in France and Réunion Island with those of working people in Britain and Mauritius. 


\section{From Servants to Indentured Immigrants: The Case of Mauritius}

The indenture contract, which historians have usually considered a form of forced labor, was not placed in this category until the middle of the nineteenth century. Until that point, ever since the seventeenth century, indenture had been viewed in the strictest sense as an expression of free contract; the individual bound by the contract was just a servant whose travel expenses were paid in advance and who committed himself for a longer period of time than a laborer but for a shorter one than a domestic servant. Like the others, however, he owed all this time to his master, who could sell the indentured servant along with any debts he still owed to someone else. Just as a master in Great Britain had the right to recover fugitives, so too in the colonies: indentured servants who fled were subject to criminal penalties. Without the Master and Servant Acts, indenture would not have been possible. The labor contract was no fiction, but a real tool in the master's hand. This situation was all the more important in that masters in the colonies gradually obtained broader rights than masters in Great Britain. They could exercise corporal punishment, authorize the marriage of indentured servants, etc. ${ }^{99}$

An innovation occurred around the middle of the eighteenth century in the American colonies: the magistrates decided that indentured servants but not Native Americans could be subject to criminal penalties. This was the first colonial innovation in relation to English case law. Indenture contracts nevertheless continued to provide criminal penalties for whites, until the 1830s. For the others-i.e., Indians, Africans, and Chineseindenture contracts and the corresponding forms of servitude continued to be practiced until the early twentieth century; in other words, several decades after the abolition of slavery. ${ }^{100}$ The same situation prevailed in the other English colonies in Central and South America and, above all, in Asia. We can therefore distinguish two periods: the first, from the seventeenth century to the 1830 s, concerned some 300,000 European indentured servants. It took place while slavery was still legal and European traders engaged in the slave trade. The indentured servants were intended for tobacco plantations and, to some degree, for manufacturing.

The second phase, in the nineteenth and twentieth centuries, concerned two million indentured servants, mostly Chinese and Indians, but also Africans, Japanese, and immigrants from the Pacific islands. They were employed in sugar plantations and in manufacturing. Unlike the indentured servants of the first phase, these new bonded laborers seldom returned to the world of free labor once their period of commitment ended. Their indenture contracts were therefore renewed. ${ }^{101}$ 
It is in this context that Mauritius is of particular interest-and for several reasons. After an initial period, during which the island belonged to the Dutch (1638-1710), Mauritius became a French colony like Canada, and then, in 1810, part of the British Empire. The first engagés arrived on Île-de-France (the French name for Mauritius) in the 1720s; they were artisans from India and other French colonies. ${ }^{102}$ In the late eighteenth century, 40 percent of free men of color in Mauritius were of Indian extraction, whereas they formed only 15 percent of the servile population. ${ }^{103}$ The English administration that succeeded the French in 1815 constantly encouraged the arrival of indentured servants from Madagascar and India and increasingly Swahilis from East Africa. ${ }^{104}$ There were many intermediaries in India, Mozambique, Madagascar, and West Africa, ranging from local sultans to village chiefs as well as Indian, Arab, and Portuguese middlemen - in addition, of course, to the French and English landowners and traders. ${ }^{105}$ The commitment terms were as varied as those we have identified on Réunion Island: in many cases, signatures to contracts were obtained by force or fraud; at the same time, many Indians signed up quite voluntarily. ${ }^{106}$

In Mauritius, between the official abolition of slavery in 1834 and 1910, 450,000 indentured servants arrived, mostly from India but also from Madagascar. Two-thirds remained, and as a result, the Indian population grew steadily-from 35 percent in 1846 to 66 percent in 1871.107 Numerous observers drew attention to the inhuman living conditions of these immigrants. ${ }^{108}$ These figures must also be expanded to include other indentured servants from South Asia and Africa: 30,000 in 1851 and twice that number ten years later. These two forms of immigration to Mauritius led to protests from English landowners and from sectors such as the railway in India and East Africa, complaining of unfair competition on the part of the Mauritians aided by the French, who contributed to this human trafficking both before and after $1848 .{ }^{109}$ Female immigration to Mauritius remained secondary, at least initially, and had to be overseen by the state. ${ }^{110}$ It did not develop rapidly until the mid-nineteenth century, after the abolition of slavery, due to the arrival of new indentured servants who came with their families and owing to the considerable demand for domestic and urban labor as well more traditional labor on the sugar plantations.

Similar uncertainty surrounds the relationships between former slaves and new indentured servants. Some authors think that the slaves were marginalized in Mauritian society, ${ }^{111}$ while others emphasize that their status changed to that of small landowners or shopkeepers and they were therefore much better integrated than Indian coolies after the abolition of slavery. ${ }^{112}$ 
At the same time, even with equal legal status, differences emerged between former slaves and the new indentured servants. These two groups were sometimes of different ethnic origin: the former slaves were African and in part Indian; the engagés were usually Indians, but as time went by, African immigration also increased. ${ }^{113}$ Along with ethnic origin, the period of immigration and whether the individual was a former slave were important factors. ${ }^{114}$ Newcomers often agreed to work for lower wages than former slaves, causing the latter to protest and thus playing into the hands of the landowners. ${ }^{115}$

As on Réunion Island, the real conditions of workers depended not only on the period in which they came and their ethnic origin, but also on which specific estates they worked on. Small plantation owners were more concerned about fugitive, insubordinate and vagrant indentured servants, ${ }^{116}$ whereas large plantation owners, who complained of the excessive cost of slave surveillance, often imposed a liberal ideology on the colonial systems; they found support for the indenture system in humanitarian and anti-slavery associations by underscoring the benefits of free immigration (indenture) as opposed to slavery as well as the purported "famine" in India and Africa. ${ }^{117}$

Despite the efforts of British abolitionists, who were on the lookout for any form of disguised slavery, the conditions of these immigrants remained quite harsh and the law difficult to enforce. Indenture contracts were governed by the provisions of the Master and Servant Acts in the colonies $^{118}$ and were greatly inspired by practices in Great Britain. It was undoubtedly extremely challenging for workers to make use of the law; the local magistrates were corrupt and had close ties to the plantation owners. The terms for reimbursing travel expenses were often complex and only vaguely explained at the time of commitment, thus leaving the immigrant indebted for life. ${ }^{119}$ This drew protests from the anti-slavery movement in Great Britain as well as from the Indian colonial authorities. ${ }^{120}$ The Free Labor Association replied that the landowners had the right to recover the travel expenses they had advanced and that the market price did not allow them to raise the wages of the engagés to the level of other wage earners. ${ }^{121}$ All the same, the immigrants often complained of ill treatment, withheld wages, and poor food. ${ }^{122}$ The estate inspectors, who were introduced specifically to oversee these relationships, confirmed the abuses, ${ }^{123}$ however, in spite of the creation of a body of magistrates appointed by London in the early 1840s, the courts seldom ruled in favor of the immigrants. ${ }^{124}$ The planters succeeded in convincing the magistrates that the indentured servants had invented "malicious" complaints against them and should be punished for it. ${ }^{125}$ The number of cases in which indentured servants brought proceedings against their 
masters-something that rarely happened in the 1850s-rose sharply thereafter. Between the 1860s and 1870s, about 10 percent of all indentured servants sued their masters, in virtually every case for nonpayment or insufficient payment of wages, and they won in more than 70 percent of these cases. ${ }^{126}$ This result, partly due to pressure from England, would hardly indicate that the "march to equality" was underway. In subsequent years the percentage of contracts denounced by coolies declined first by 5 percent overall (at end of the 1870s) and later dropped to a mere 0.3 percent between 1895 and 1899 , with the success rate falling to less than 40 percent. ${ }^{127}$ This can be explained by the fact that, after the results of the 1860s and thanks to a new law on labor contracts adopted in 1867, more and more contracts were oral and it was therefore more difficult for the coolies to produce any proof that would hold up in court. Above all, the coolies' contracts were no longer drawn up with the plantation owners but instead with Indian middlemen, which no doubt helped to quash many conflicts. Retention of coolies increased, as both the result and source of this process, with the percentage of contract renewals rising from 40 percent in 1861 to more than 70 percent twenty years later. ${ }^{128}$

The law was largely enforced when immigrants were sued. Any unjustified absence was subject to criminal prosecution. ${ }^{129}$ In particular, the law against vagrancy took on particular importance in Mauritius; several restrictive laws were adopted between the abolition of slavery and the 1870s. ${ }^{130}$ Their adoption testifies to the same concerns that prompted laws limiting the mobility of workers and peasants in the rest of the British Empire; but as we have seen, in the French Empire as well, considerations of public order (monitoring movements, knowing the exact location of the immigrants and amount of their wages) converged with those involving competition among employers. Small landowners complained of runaway engagés, a problem that also stemmed from lack of cooperation on the part of large landowners. ${ }^{131}$ Between 1860 and 1870 , landowners and employers filed some 70,000 complaints against Indian immigrants; in 80 percent of the cases they pertained to desertion or illegal absence. ${ }^{132}$ The other landowners refused to collaborate, so these complaints often came to nothing, which is why many of them preferred to resort to newcomers. ${ }^{133}$

In summary, the status of bonded laborers, indentured servants, and others was modeled on the status of apprentices and servants in Great Britain. The gap separating servant and master was not as great as the one between indentured servants and their masters, which continued to grow during the nineteenth century. In Mauritius, 14,000 indentured and domestic servants were prosecuted each year in the 1860s; during the same period in Great Britain, proceedings were brought against 9,700 
servants per year for breach of contract and almost always resulted in convictions. By contrast, masters were seldom indicted and even more rarely convicted for breach of contract, ill treatment, or nonpayment of wages. At the same time, even though the real conditions of indentured servants were not necessarily better than those of the slaves who preceded them, the rights they enjoyed and the fact that their status was not hereditary were essential differences that were to play an increasingly important role in the twentieth century.

\section{Toward a New World?}

Instead of a history made up of slaves, bonded people, and free wage earners - or analogously, consisting of an old regime and capitalism, with a triumphant passage from one to the other-our findings suggest something altogether different. The French Revolution suppressed lifelong domestic bondage, while the nineteenth century progressively abolished slavery in the British colonies first, and then in the French colonies. Still, this process did not accompany the rise of a free labor market between legally equal actors. In Britain, France, and their colonies, workers and indentured immigrants were not disguised slaves (as much literature of the nineteenth century argued), ${ }^{134}$ but they did have an inferior legal status and far fewer rights than their masters. From this perspective, colonies were territories not only of slavery but, above all, of forms of bondage inspired by status inequalities entrenched in Europe. Status inequalities in France and Britain served as the model for those in the colonies, but the engagés, bonded laborers, domestic servants, and wage earners were expressions of free contract. While relying on older institutions and practices, new institutions and forms of labor were introduced in the seventeenth century: indenture contracts, contractual forms of domestic service, apprenticeship, and engagement in the colonies. Indeed, territorial and colonial expansion, along with the growth of agriculture and trade, followed by proto-industrial and later industrial development, gave rise to a complex overall dynamic. Increasingly large population shifts took place within empires, between one empire and the other, and between city and country. It is therefore important to draw a distinction between living conditions and legal rights (as well as the possibility of their exercise). In the areas studied as a whole, there were status differences between domestic servants and property owners; between laborers and their employers; between engagés and indentured laborers; and between servants and apprentices and their masters. These differences in status were not only produced by the colonies; they existed in Europe as well and were hardly an expression of the Old Regime. On the contrary, such status differences 
persisted through supposed political and economic revolutions. The existence of certain rights accorded the engagés (with a notable difference between white and non-European engagés) is important, because it allows us to distinguish the figures of ideal cases, such as former slaves or North American chattel slavery, from free wage earners. An engagé was not a slave-he was subject to forms of bondage that were not formally or necessarily hereditary, even though the debts from such bondage were quite frequently passed on to the descendants. Unlike traditional slave status, however, the legal condition of engagé was not automatically transferred to his or her descendants, and this made all the difference in the evolution of post-slavery forms of labor in the twentieth century.

This observation means that we should revise our view of the comparative evolution of economic and legal labor systems. From an economic standpoint, forced labor has traditionally been associated with preindustrial economies and the colonies. The history we have just recounted calls these clear-cut divisions into question. It would be a mistake to associate forced labor and slavery in the colonies with the plantation economy and to conclude that emigration prior to plantations consisted in colonization by white settlers and that later on, with the advent of mechanized labor on the plantations, recourse to slavery no longer made sense. We have seen instead that the conditions accompanying the bondage of whites in the seventeenth and early eighteenth century were quite harsh and did not improve until the arrival of engagés and slaves of color (and even then, with notable exceptions such as child vagrants). Prior to this shift, the formal abolition of slavery was above all the result of a political movement and only partially related to technological changes on the plantations, which remained labor intensive and resorted to engagés whose living conditions (but not their status) closely resembled those of slaves.

Local conditions played an important role. On Réunion Island, indentured immigrants met with constant difficulties in availing themselves of the law. When they were successful, it was usually due to British and French political intervention and depended on unfair competition between employers. At the same time, the crisis in the sugar market, followed by successful competition from Mauritius, lack of capital, and competition from sugar beets in northern France finally swept away most of the small planters and small units. Former indentured immigrants benefited in part from this trend and gained access to marginal land. "Small whites" and former indentured laborers shared their social inferiority and distrusted each other.

In Mauritius, former indentured immigrants enjoyed greater social mobility, more favorable economic trends, and political support among British and colonial elites. Paradoxically, labor protection arrived later 
in Britain than in France, yet the defense of immigrant rights improved sooner on Mauritius than on Réunion Island. The anti-bondage movement in the British colonies was much more closely allied with the proworker movement in Britain than its counterpart in the French colonies was to greater worker protections in France.

The evolution that we have presented here did not necessarily correspond to a passage from constraint to freedom, which is a rather Eurocentric view and should therefore be reexamined. In particular, the official abolition of slavery in the French colonies was important, if only so as to eliminate any form of dominance through status or heredity. This change was accompanied by the introduction of extremely restrictive forms of contracts and status for immigrants. The forms of domestic service, criminal penalties, and rules for the colonies were reinforced at the very moment when labor law in Europe was becoming more favorable to wage earners. But how did this happen?

\section{Notes}

A version of this chapter has been published under the title: "Local Bondage in Global Economies: Servants, Wage-Earners and Indentured Migrants in Nineteenth-Century France, Britain, and the Mascarene Islands," Modern Asian Studies, 47,4 (2013): 1218-51. I acknowledge my gratitude to Cambridge Journals and Cambridge University Press.

1. Rebecca Scott, et al, Societies after Slavery: A Selected Annotated Bibliography of Printed Sources on Cuba, Brazil, British Colonial Africa, South Africa and the British West Indies (Pittsburgh: University of Pittsburgh Press, 2004); Rebecca Scott, "Defining the Boundaries of Freedom in the World of Cane: Cuba, Brazil, and Louisiana after Emancipation," American Historical Review 99, 1 (1994): 70-102; Joseph Calder Miller, Slavery and Slaving in World History: A Bibliography, 1900-1996 (Armonk, NY: M. E. Sharpe, 1999); Olivier Pétré-Grenouilleau, Les traites négrières (Paris: Gallimard, 2004). Regarding the definition of slavery, see Claude Meillassoux, Anthropologie de l'esclavage (Paris: PUF, 1986); Moses Finley, Ancient Slavery and Modern Ideology (New York: Viking Press, 1980); Eric Williams, Capitalism and Slavery (Chapel Hill: University of North Carolina Press, 1944); Orlando Patterson, Slavery and Social Death: A Comparative Study (Cambridge: Cambridge University Press, 1982); and Paul Lovejoy, Transformations in Slavery: A History of Slavery in Africa (Cambridge: Cambridge University Press, 1983).

2. Utsa Chakravarti, "Of Dasas and Karmakaras: Servile Labor in Ancient India," in Chains of Servitude: Bondage and Slavery in India, ed. Utasa Patnaik and M. Dingawaney (New York: Oxford University Press, 1985), 4054; Markus Vink, "The World's Oldest Trade: Dutch Slavery in the Indian Ocean in the Seventeenth Century," Journal of World History 14, 2 (2003): 131-77; Lauren Benton, Law and Colonial Culture (Cambridge: Cambridge University Press, 2002); Michael Craton, Empire, Enslavement and Freedom in the Caribbean (Kingston: I. Randle Publishers, 1997); Marc Galanter, Law and Society in Modern India (Delhi: Oxford University Press, 1989); Hay and Craven, Masters, Servants, and Magistrates; Alan Watson, Slave Law in the Americas (Athens, GA: University of Georgia Press, 1989). 
3. Vink, "The World's Oldest Trade."

4. Watson, Asian and African Systems. Scarr, Slaving and Slavery.

5. Anthony Reid, Slavery, Bondage, and Dependency in South-East Asia (London: MacMillan, 1984).

6. Marina Carter, "Slavery and Unfree Labor in the Indian Ocean," The History Compass 4, 5 (2006): 800-813.

7. The accent put on the peaks does not exclude another chronology, based upon the simultaneous evolution of the forms of labor and of navigation. In this case, the arrival of the Europeans has to be distinguished from the period running from the seventeenth century to the beginning of the steam era (1860) and from the steam era itself (1860-1970). On this see Erik Gilbert, "Coastal East Africa and the Western Indian Ocean: Long-distance Trade, Empire, Migration, and Regional Unity," The History Teacher 36, l (2002): 7-34.

8. Gwyn Campbell, "Slavery in the Indian Ocean World," in Gad Heuman and Trevor Burnard eds., The Routledge History of Slavery (London: Routledge, 2011): 52-63; William Gervase Clarence-Smith, ed., The Economics of the Indian Ocean Slave Trade (London: Frank Cass, 1989); Gwyn Campbell, ed., The Structure of Slavery in the Indian Ocean, Africa and Asia (London: Frank Cass, 2004).

9. Randall Pouwels, "Eastern Africa and the Indian Ocean to 1800: Reviewing Relations in Historical Perspective," The International Journal of African Historical Studies 35, 2/3 (2002): 385-425; Gwyn Campbell, "Madagascar and the Slave Trade, 1810-1895," The Journal of African History 22, 2 (1981): 203-27; Rene J. Barendse, The Arabian Seas: The Indian Ocean World of the Seventeenth Century (London: M.E. Sharpe, 2002).

10. Ralph Austen, "The Trans-Saharan Slave Trade: A Tentative Census," in The Uncommon Market: Essays in the Economic History of the Atlantic Slave Trade, ed. Jan S. Hogendorn (New York: Academic Press, 1979).

11. Pier Larson, "African Diasporas and the Atlantic," in Jorge Canizares-Esguerra and Erik Seeman, The Atlantic in Global History, 1500-2000 (Upper Saddle River: Pearson Prentice Hall, 2007): 129-47.

12. Kirti N. Chaudhuri, Trade and Civilisation in the Indian Ocean: An Economic History from the Rise of Islam to 1750 (Cambridge: Cambridge University Press, 1985); Kirti N. Chaudhuri, Asia Before Europe: Economy and Civilisation of the Indian Ocean from the Rise of Islam to 1750 (Cambridge: Cambridge University Press, 1992); André Wink, Al-Hind: The Making of the Indo-Islamic World, 3 vols. (Leiden: Brill, 1996); Clarence-Smith, The Economics; Campbell, The Structure of Slavery; Frederick Cooper, Plantation Slavery on the East Coast of Africa (New Haven: Yale University Press, 1977). James Watson, ed., Asian and African Systems of Slavery (Berkeley and Los Angeles: University of California Press, 1980).

13. Esmond B. Martin, T. C. Ryan, "A Quantitative Assessment of the Arab Slave Trade of East Africa, 1770-1896," Kenya Historical Review 5, 1 (1977): 71-91.

14. Alpers, Ivory and Slaves.

15. Gwyn Campbell, "Madagascar and Mozambique in the Slave Trade of the Western Indian Ocean, 1800-1861," in Clarence-Smith, The Economics, 166-93.

16. Thomas Vernet, "Le commerce des esclaves sur la côte swahilie, 1500-1750," Azania 38 (2003): 69-97; Michael N. Pearson, Port Cities and Intruders, the Swahili Coast, India, and Portugal in the Early Modern Era (Baltimore: Johns Hopkins University Press, 1998).

17. Pedro Machado, "A Forgotten Corner of the Indian Ocean: Gujarati Merchants, Portuguese India, and the Mozambique Slave Trade, c. 1730-1830," in Campbell, The Structure of Slavery, 17-32.

18. Vink, "The World's Oldest Trade."

19. Timothy M. McKenna, Muslim Rulers and Rebels (Berkeley: University of California Press, 1998). 
20. Sanjah Subrahmanyam, The Portuguese Empire in Asia, 1500-1700: A Political and Economic History (New York: Longman, 1993); Alpers, Ivory and Slaves; Abdul Sheriff, Slaves, Spices and Ivory in Zanzibar: Integration of an East African Commercial Empire into the World Economy, 1770-1873 (London: James Currey, 1987).

21. Austen, "The Trans-Saharan Slave Trade," 66, table 2.8; Ralph Austen, "The Nineteenth-century Islamic Slave Trade from East Africa (Swahili and Red Sea Coasts): A Tentative Census," Slavery and Abolition 9 (1988): 21-44.

22. Lovejoy, Transformations in Slavery, 61-62, 155-58.

23. Clarence-Smith, The Economics: Introduction: 4-8.

24. Sven Beckert, "Emancipation and Empire: Reconstructing the Worldwide Web of Cotton Production in the Age of the American Civil War," The American Historical Review 109, 5 (2004): 1405-38.

25. A. Roger Ekirch, Bound for America: The Transportation of British Convicts to the Colonies, 1718-1775 (Oxford: Clarendon Press, 1987); Alan George Levers Shaw, Convicts and the Colonies: A Study of Penal Transportation from Great Britain and Ireland to Australia and Other Parts of the British Empire (London: Faber 1966); Gwenda Morgan and Peter Rushton eds. Eighteenth-century Criminal Transportation:The Formation of the Criminal Atlantic (Basingtoke: Palgrave Macmillan, 2004).

26. Stephen Nicholas ed., Convict Workers: Reinterpreting Australia's Past (Cambridge: Cambridge University Press, 1989).

27. Clare Anderson, Convicts in the Indian Ocean: Transportation from South Asia to Mauritius, 1815-1853 (Basingstoke: Macmillan, 2000): 5.

28. Frank Lewis, "The Cost of Convict Transportation from Britain to Australia, 1796-1810," Economic History Review XLI, 4 (1988): 507-24.

29. Kenneth Morgan, "Convict Runaways in Maryland, 1745-1775," Journal of American Studies 23, 2 (1989): 253-68.

30. Ekirch, Bound for America.

31. Lewis, "The Cost of Convict Transportation."

32. Anderson, Convicts in the Indian Ocean, 16.

33. Mauritius National Archives (henceforth MNA) RA 132, Rossi to Barry, 1823.

34. Anderson, Convicts in the Indian Ocean, 98-99.

35. For an economic analysis comparing white indentured and convict labor in North America, see Farley Grubb, "The Transatlantic Market for British Convict Labor," The Journal of Economic History 60,1 (March 2000): 94-122.

36. Gabriel Debien, Les engagés pour les Antilles 1634-1715 (Paris: Société de l'histoire des colonies françaises, 1952).

37. Louise Dechêne, Habitants et marchands de Montréal an XVIIe siècle (Paris: Olstrom, 1974).

38. Fréderic Mauro, "French Indentured Servants for America, 1500-1800." In Colonialism and Migration: Indentured Labor before and after Slavery, ed. Pieter C. Emmer (Dordrecht, Boston, Lancaster: Martinus Nijhoff Publisher, 1986): 83-104.

39. Debien, Les engages, 45 .

40. See the Archives Charente Maritime, Minutier Teuleron, 1638-1680, in particular the groups of documents from 1638, 1641, 1649, 1651, 1666-67, 1670, and 1671. See also the Bibliothèque nationale, section des manuscrits, "Nouvelles acquisitions de France," 9328 , which has copies of documents on immigration to the colonies that pertain to inhabitants, engages, and slaves.

41. Bibliothèque nationale, section des manuscrits, "Nouvelles acquisitions de France," 9328

42. For treatments of apprenticeship contracts, see Michael Sonencher, Works and Wages: Natural Law, Politics and the Eighteenth-century French Trades (Cambridge: Cambridge University Press 1989); Kaplan, La fin des corporations. 
43. For example, see Archives Charente Maritime, Grozé minutes, 28 May 1692; and the Rivière minutes, 31 May 1684.

44. For example, see the Archives Charente Maritime, Ex Moreau minutes, 19 and 25 April 1664.

45. Régent, La France, 24.

46. Dechêne, Habitants.

47. David W. Galenson, White Servitude in Colonial America (Cambridge: Cambridge University Press, 1981).

48. Campbell, The Structure of Slavery.

49. See Fillot, La traite; Sudel Fuma, L'esclavagisme à la Réunion. 1794-1848 (Paris: L'Harmattan, 1992); Jacques Weber, "L'émigration indienne des comptoirs, 1828-1861," Etudes et documents IHPOM 11 (1979): 133-59; and Richard Allen, Slaves, Freedmen, and Indentured Laborers in Colonial Mauritius (Cambridge: Cambridge University Press, 1999).

50. Fillot, La traite.

51. Ibid., 54-69.

52. Richard Allen, "The Mascarene Slave Trade and Labor Migration in the Indian Ocean during the Eighteenth and Nineteenth Centuries," in Campbell, The Structure of Slavery, $33-50$, in particular, 36 .

53. Edward Alpers, "The French Slave Trade in East Africa, 1721-1810," Cabiers d'études africaines 10, 37 (1970): 80-124.

54. See Monica Schuler, "The Recruitment of African Indentured Laborers for European Colonies in the Nineteenth Century," in Emmer, Colonialism and Migration, 125-61; Alpers, Ivory and Slaves; and Hubert Gerbeau, "Quelques aspects de la traite illégale des esclaves à Bourbon au XIXe siècle," Mouvements de populations dans Indian Ocean (Paris: Imprim Champion, 1979), 273-96. See also Louis Maillard, Notes sur l'île de la Réunion (Paris: Dentu, 1862); and P. Thomas, Essai de statistiques de l'île Bourbon, 2 vols. (Paris: Bachelier, 1828).

55. Allen, "The Mascarene Slave Trade," 37-38.

56. The National Archives (TNA), CO 415/9/A.221, 1827.

57. CAOM 30 COL 117, 160, 639, années 1823-1836. See also the Archives départementales de la Réunion (ADR), in particular: $57 \mathrm{Ml}$, for example: "Exposé de la situation intérieure de la colonie en 1832 par le directeur de l'intérieur" and "Rapport sur les différents services de la colonie" from 1828.

58. Drescher, Capitalism and Antislavery; and David Brion Davis, The Problem of Slavery in the Age of Revolution, 1770-1823 (New York: Oxford University Press, 1999).

59. Louis Maillard, Notes sur l'ile Bourbon (Paris: Dentu, 1862), 190.

60. Bulletin officiel de l'Ile Bourbon, arrêté du 3 juillet 1829.

61. Megan Vaughan, Creating the Creole Island Slavery in Eighteenth-century Mauritius (Durham, London: Duke University Press, 2007).

62. Archives départementales de la Réunion (ADR) 168 M 3.

63. Fuma, L'esclavagisme, 116.

64. Centre des Archives d'Outre-Mer (CAOM) FM SG/Reu c 380 d 3288, c 370 d 3180.

65. ADR 168 M 3, "Lettre du commissaire de Saint-Paul, le 14 septembre 1842" and "Séance de travail de la commission de surveillance des indiens engagés, le 4 mars 1831," as quoted in Fuma, L'esclavagisme, 116, 122.

66. CAOM, FM SG Inde 464, d. 590, lettre 26 February 1848.

67. Bulletin officiel de l'Ile Bourbon, "Arrêté du 10 novembre 1843," 354.

68. CAOM FM SG/Reu c 406, c 432 d 4603 à 4606 (Chinese immigration).

69. Fuma, Lesclavagisme, 129.

70. Bulletin officiel de l'Ile Bourbon, arrêté 2 July 1846.

71. Lindicateur colonial, 12 April 1845. 
72. CAOM, Réunion, tableau de l'immigration africaine à la Réunion de 1848 à 1869, C 454, d 5042 à 5074. See also Ho Hai Huang, Histoire économique de l'île de la Réunion, 18491881: engagisme, croissance et crise (Paris: Lavoisier, 2004).

73. Schuler, "The Recruitment"; and François Renault, Libération d'esclaves et nouvelle servitude: les rachats de captifs africains pour le compte des colonies françaises après l'abolition de l'esclavage (Abidjan: Les nouvelles éditions africaines, 1976).

74. Sidi Ainouddine, "L'esclavage aux Comores. Son fonctionnement de la période arabe en 1904," in Esclavage et abolition dans l' Océan Indien, 1723-1869, ed. Edmund Maestri (Paris: L'Harmattan, 2002), 89-114; and in this same book, Mohamed M'Trengoueni, "Les différentes formes de l'esclavage et leurs abolitions successives à Mayotte," 141-52.

75. Ainouddine, "L'esclavage aux Comores," 102.

76. See Sudel Fuma, Esclaves et citoyens, le destin de 62,000 Réunionnais, histoire de l'insertion des affranchis de 1848 dans la société réunionnaise (Saint-Denis, La Réunion: F.R.D.O.I., 1979, 2nd ed., 1982); and Virginie Chaillou, De l'Inde à la Réunion. Histoire d'une transition. L'épreuve du lazaret, 1860-1882 (Saint-André de la Réunion: Océan éditions, 2002).

77. Jacques Weber, "L'émigration indienne à la Réunion: 'contraire à la morale' ou 'utile à l'humanité," in Maestri, Esclavage, 309-28.

78. Schuler, "The Recruitment," 140.

79. Le Moniteur de la Réunion, 3 July 1852.

80. Bulletin officiel de l'île de la Réunion, 13 February 1852.

81. Accounts of litigation can be found in U 339, 349, at the Archives départementales de la Réunion (ADR). On women, see Fuma, Esclaves.

82. CAOM FM SM/Reu c 379 d 3211 and c 383 d 3323.

83. CAOM FM SG/Reu c 384 d 3361.

84. CAOM FM SG/Reu c 384 d 3341, reports of the syndic of immigrants, 1858 and 1859 to 1864 .

85. CAOM FM SG/Reu c 384 d 3341.

86. Northrup, Indentured Labor, 129-32.

87. CAOM FM SG/Reu c 382, some dozen files, and c 379 .

88. CAOM FM SG/Reu c 379 d 3211.

89. CAOM FM SG/Reu c 382 d 3324, 3310, 3311, 3318.

90. CAOM FM SM SG/Reu c 379 d 3217,3210 .

91. CAOM FM SM SG/Reu c 382 d 3323.

92. CAOM FM SM SG/Reu c 379 d 3203.

93. CAOM FM SG/SG Reu c 385 d 3367.

94. Justice cour d'assise, Saint-Denis, 3e session 1868 CAOM FM SG/SG Reu c 385 d 3367.

95. Northrup, Indentured Labor, 31; and Allen, Slaves, 23.

96. See CAOM FM SG/Reu c 400 d 3688; and c 514 d 5970. See also Alexandre Bourquin, Claude Prudhomme, and Hubert Gerbeau, Histoire des petits-blancs à la Réunion (Paris: Karthala, 2005).

97. CAOM FM SG/Reu c 515 d 6005 .

98. Drescher, Abolition.

99. Galenson, White Servitude.

100. Steinfeld, The Invention of Free Labor.

101. Northrup, Indentured Labor, 156-57, table A.1.

102. Allen, Slaves, 84. Claude Wanquet, "Violences individuelles et violence institutionnalisée: le régime servile de l'Ile de France à la fin du XVIIIe siècle à la lumière des dossiers de procédure criminelle," in Maestri, Abolition, 203-26. Hubert Gerbeau, "Les indiens des Mascaraignes. Simples jalons pour l'histoire d'une réussite (XVIle-XXe siècle)," Annuaire des pays de Indian Ocean, XII (1990-1991): 15-45.

103. Musleem Jumeer, Les affranchissements et les libres à lile de France à la fin de l'Ancien Régime, 1768-1789, PhD, Université de Poitiers, 1979, 24,54, 105, 212-14. 
104. Carter, Servants, Sirdars, and Settlers.

105. Vijaya Teelock, Bitter Sugar: Sugar and Slavery in Nineteenth-Century Mauritius (Moka: Mahatma Gandhi Institute, 1998).

106. Correspondence concerning the Indian immigration to Mauritius can be found in: British Parliamentary Papers, 1840 XXXVII (331), 1842 XXX (26), 1844 XXXV (356 et 530), 1846 XXVIII (691 II). Also TNA CO 167/245, Stanley 26 July 1843.

107. Allen, Slaves, 16-17. See also, Auguste Toussaint, Histoire de l'ile Maurice (Paris: PUF, 1974).

108. Colony of Mauritius, annual report, 1854, British Parliamentary Papers XLII, 2050. See also, Jan Breman, Taming the Coolie Beast (Delhi: Oxford University Press, 1989).

109. British Parliamentary Papers, 1841 XVI (45), Petition of the inhabitants of Calcutta.

110. Carter, Servants, Sirdars, and Settlers, 3.

111. Satteeanund Peerthum, "Le système d'apprentissage à Mauritius 1835-1839: plus esclave mais pas encore libre," in Maestri, Abolition, 285-94; Jocelyne Chan Low, "Aux origines du malaise créole? Les ex-apprentis dans la société mauricienne, 1839-1860," in Maestri, Abolition, 267-84.

112. Allen, Slaves.

113. MNA RA 1955, 2205.

114. MNA RA 862; HA 66.

115. Chan Low, "Aux origines du malaise créole?"

116. MNA, HA 66 (planters' petitions); British Parliamentary Papers 1842 XXXX (26): 25.

117. MNA HA 66.

118. Allen, Slaves, 60.

119. MNA RA 1955; British Parliamentary Papers 1836 XLIX (166), 1837-8 LII (180); 1840 XXXVII (58); 1847-8 XLVI (250); TNA CO 167/201.

120. British Parliamentary Papers, 1837-8 LII (180).

121. British Parliamentary Papers, 1837-8 LII (180), 1849 XXXVII (280).

122. British Parliamentary Papers, 1842 XXX (26).

123. TNA CO 167/263. Labor committee evidence, appendix A, oct 22 1845. British Parliamentary Papers, 1847 XXXIX (325).

124. MNA RA 1955; TNA CO 167/263. Labor committee evidence, appendix A, 22 October 1845, British Parliamentary Papers, 1847 XXXIX (325).

125. TNA CO $167 / 213,202,266$. MNA HA 66, RA 1264.

126. "Report of the Royal Commissioners Appointed to Enquire into the Treatment of Immigrants in Mauritius," in British Parliament Sessional Papers, 1875 XXXIV, paragraph 704 and appendix A and B. Colony of Mauritius, printed documents, Annual Report of the Protector of Immigrants, 1860-1885.

127. Ibid.

128. Allen, Slaves: 72.

129. MNA RA 1023, 1459.

130. MNA RA 1459.

131. MNA HA 66.

132. MNA RA 1955, 2205; Colony of Mauritius, Protector of Immigrants. Annual Report.

133. TNA CO $167 / 252$; MNA H66.

134. On this debate, see Alessandro Stanziani, "Free Labor-Forced Labor: An Uncertain Boundary? The Circulation of Economic Ideas between Russia and Europe from the Eighteenth to the Mid-nineteenth Century," Kritika: Explorations in Russian and Eurasian History 9, l (2008): 1-27. 


\section{CONCLUSION \\ The Collapse and Resurgence of Bondage}

The world of labor and unequal rights depicted in this book did not collapse with the French Revolution or the British Industrial Revolution, but only between 1870 and 1914. Serfdom was abolished in 1861; American slavery in 1865; the Master and Servant Acts were repealed in 1875; and the indentured contract was abolished in India, in 1916. Between the 1890s and World War One, the European powers decreed the abolition of African slavery, while new labor rules were adopted almost everywhere in Europe. To many contemporary observers and more recent scholars these interrelated changes seemed to depict an irreversible and worldwide march toward freedom. But was that actually so?

I do not intend to elaborate a fully detailed answer to a question for which an entire volume would be necessary (a volume that will, indeed, follow this book). I rather suggest hypotheses and broad trends in the evolution of labor rights as practiced in the three main areas examined above-wage labor in Europe, indentured labor in the colonial world, and certain forms of labor in post-emancipation Russia.

\section{Collective Bargaining and the "New" Labor Contract in Western Countries}

Between the 1890s and the 1920s there emerged what today we call the labor contract (contrat de travail in French, contract of employment in Britain). These new legal institutions marked a departure from the labor institutions that had sustained the economic growth and the social transformations of Europe between the seventeenth and mid-nineteenth century. 
In England, at the start of the 1870s, most industrial enterprises were still independent family-run firms that employed fewer than a hundred workers. Mass production was slow in evolving and was still quite rare by $1870 .{ }^{1}$ By the mid-nineteenth century, a decisive shift occurred toward an industrialized economy in which sustained increases in output per capita were able to support a growing population, which, in a virtuous circle, provided a source of rising demand. ${ }^{2}$ From the mid-1880s on, large combines of firms began to emerge, notably in textiles, coal, and engineering. This process was paralleled by changes in the nature of intrafirm organization: Managerial functions grew, while technical change influenced the contract system. Internal contracting was often bound up with traditional methods of craft control, which came under pressure from increased mechanization. Vertical integration, the welfare state, and changing labor institutions went hand in hand. Vertical integration required a stable labor force and large units; the peasant-worker, the traditional poor, and Poor Laws hardly fit this process. For Sidney and Beatrice Webb, the emergence of a fully developed and stable form of trade-union organization in the middle decades of the nineteenth century was associated with the establishment of wage labor as the predominant form of work relationship. ${ }^{3}$ Under the Statute of Artificers and Apprentices, the journeymen's association was nothing more than a subordinate department of the masters' guild. Picketing was a criminal offence, and under the Master and Servant Acts, individual workers taking part in strikes were liable to prosecution. The Trade Union Act and Criminal Amendment Act of 1871, as well as the Conspiracy and Protection of Property Act and the Employers and Workmen Act, both of 1875 , provided a basis for union growth. Trade union membership grew steadily after 1870; membership in 1914 was double that of $1905 .^{4}$

The removal of criminal sanctions from the individual employment relationship in the 1870s was soon followed by the first legislative interventions of the welfare state. A wave of social legislation began with the Employers' Liability Act of 1880, according to which an employer could not be held liable in tort where one employee's negligence caused personal injury to another. From this small beginning, the first Workmen's Compensation Act was introduced in 1897, and the first National Insurance Act, in 1911. They imposed liability on employers for workplace-related injuries and disease, and they prompted the widespread use of employers' liability insurance to spread the risks in question. ${ }^{5}$ This same act made unemployment compensation available on the basis of contributions paid by individual wage earners (limited to some industrial sectors and extended to other sectors and agriculture only in 1936). These changes 
meant that the Poor Law remained in place but dealt only with residual cases that fell outside the range of the statutory social-insurance scheme. ${ }^{6}$

The growth of collective bargaining, supported by the state, contributed to the same process. Prior to 1870 , the restricted legal status of unions limited collective bargaining. After 1875, with the repeal of criminal penalties in both labor contracts and union activity, collective agreements emerged in particular trades. In some sectors (engineering, shipbuilding, and construction), attempts were made to regulate and limit piecework, with unilateral union control of employment conditions being the ultimate goal. In some other sectors (iron and steel, the coal industry) collective bargaining took the form of joint control between trade unions and employers' associations. Finally, in a third group of sectors (dock work; road, rail and river transports; tailoring, dressmaking, laundry work), associations were too weak to establish either controls over the labor supply or controls over forms of the joint regulation of minimum terms and conditions. ${ }^{7}$

Despite advances, seasonal and casual workers were excluded from these provisions and were designated independent contractors. ${ }^{8}$ Litigation thus occurred over the definition of "independent," with employers trying to avoid responsibility for the social risks of illness, injury, and unemployment.

Along an analogous path, in France, the law of 21 March 1884 legalized the unions; thus the question arose as to the lawfulness of a union pressuring an employer to dismiss a worker who was employed at will. In general, tribunals and courts still opposed any acknowledgment of collective contracts. Not until 1913 were unions authorized to defend an occupation's general interest.

Within this context the notion of the labor contract (contrat de travail) appeared. The term contrat de travail was not in widespread use in France before the mid-1880s. ${ }^{9}$ The main impetus for its adoption was an argument by employers in larger enterprises that the general duty of obedience should be read into all industrial hiring; however, once the term became established, it was used in turn-of-the-century legislation with respect to industrial accidents (law of 1898), ${ }^{10}$ which introduced the employer's objective responsibility in case of accident. This in turn opened the way to social insurances, which were being developed precisely during this period. Until then, it had been extremely hard to demonstrate an employer's liability; on the contrary, an employer had the easy task of proving the worker's "lack of precaution," even when harm was the result of the pressure the employer had put on him. The employer now had to demonstrate that he had taken all measures to guarantee the safety and protection of workers. At the core of the new concept was 
an adaptation of the notion of "subordination" - an open-ended duty to obey was accepted and indeed extended to all wage-dependent and salaried workers; but it was now traded off for the enterprise's and the state's shouldering of the burdens of social risks, ranging from health and safety to income and job security. ${ }^{11}$

The period's overall economic evolution strongly supported this trend. Until this point, seasonal workers had been perfect fits for task labor, which allowed them to return to the countryside during the summer and other periods of intensive rural activity. In the countryside as well, harvesting and other major work was remunerated in accordance with a task job; only between 1860 and 1890 did the earlier practice of combining agricultural and industrial employment largely vanish. During the summer of 1860 , at least 500,000 , and most probably 800,000 , workers quit their jobs. By 1890, this number had fallen to $100,000 .{ }^{12}$ Despite important regional and sectoral differences, as a whole, the agrarian crisis and the second Industrial Revolution attracted more stable workers, who were mostly unskilled, into the towns and the manufactures.

Public order and competition also pushed toward a new labor regime. In 1890, the worker's booklet was suppressed, and in 1900 the judiciary was asked to impose a private law solution in circumstances where public law solutions had become anachronistic.

However, the new labor law widened rather than reduced legal, social, and economic inequalities among working people. It excluded huge categories, such as small enterprises, craftsmen, and peasants. ${ }^{13}$ All these groups were marginalized as "independent" workers. ${ }^{14}$ They were not obliged to fulfill many of the obligations that other workers had toward their employers, but they also could not benefit from the same social security advantages enjoyed by other workers.

To sum up, England and France shared certain tendencies in terms of rules, labor organization, and social dynamics, during the last quarter of the nineteenth century. Common to both countries were the expanding civil and legal rights granted to the unions, the rise of the social welfare state, and the transformation of management and firms. From the 1880s to World War One there was ever greater enfranchisement. The supremacy of the landed aristocracy declined and gradually vanished to the benefit of new industrial and urban elites. Unions, strikes, and other expressions of civil society were also permitted, while women and children were granted greater legal rights.

This process went hand in hand with profound transformations in the economy. The second Industrial Revolution led to a widening gap in the capital-labor ratio. Capital investment had been increasing in Britain and other European countries since the 1860s, with the development of 
railways, iron, and chemistry. Although more intense in Germany than in Britain and France, this process was common to all three countries and helps to explain their similar shifts in labor-market institutions. Mechanization required stable and not seasonal workers, while the labor supply was increased by a strong wave of mechanization and the application of chemistry to agriculture. Urbanization thus increased and tended to become more stable; that is to say, the leading actor of previous centuries, the peasant-worker, was vanishing.

At the same time, new labor rules and social protection were limited to specific groups of workers, namely those in unionized industries and large plants. Others - small units, artisans, and peasants-were excluded from these provisions until after 1945, and this social gap grew wider in the colonial state and the global economies.

\section{Population, Migration, and Labor, 1870-1914}

In examining indentured labor in the Indian Ocean, we related its economic and social dynamics to certain major forces. Legally speaking, indentured labor was an extreme version of forms of European servants' employment regimes; from an economic perspective, it responded to the abolition first of the slave trade, then of slavery in the European colonies, and to the simultaneous increased demand for sugar, cotton, and tobacco in Western economies. Since the 1870s, the declining prices of these items and the joint process of mechanization led to decreasing immigration of indentured Indians, Chinese, and Africans in many production areas in the Antilles and the Indian Ocean. Yet migratory flux increased in the last quarter of the nineteenth century. In Europe, mechanization and concentration compelled people to migrate, while massive population flow helped create a single global economy for both labor and capital. Thus between 1840 and 1940, 55-58 million Europeans and 2.5 million Africans and Asians reached the Americas; during this same period, 29 million Indians, 19 million Chinese, and 4 million Africans and Europeans moved to Southeast Asia, the Pacific islands, and the Indian Ocean rim. Finally, 46-51 million people from northeastern Asia and Russia moved (or were compelled to move) to Siberia, Manchuria, and Central Asia. ${ }^{15}$

Economic factors were important, but they were not alone in causing this phenomenon. Given a strong boost by the revolution in transportation (the definitive success of steamboats and railroads), global migrations caused a significant shift in the distribution of the world's population. All three aforementioned destinations experienced enormous population growth, increasing by factors of 4 to 5.5 , from 1850 to 1950 . Growth rates in these areas were more than twice that of growth rates for the 
world population as a whole and about 60 percent greater than in Africa, a region of small net immigration. By comparison, growth rates in the regions of emigration were lower than world population growth and less than half of those in the regions of immigration. Taken together, the three main destination regions accounted for 10 percent of the world's population in 1850 and 24 percent in $1950 .{ }^{16}$

Even if relocation within the same empire was important (in particular in the Russian and British Empires), transimperial, intracontinental, regional, and local forms of migration were also important-and they clearly show the inadequacy of the Eurocentric paradigm, which consists of explaining migration as an expansion of the West. ${ }^{17}$

Indeed, migration was multiscaled and involved almost all areas of the world. Nearly 4 million Indians travelled to Malaysia, over 8 million to Ceylon, over 15 million to Burma, and about 1 million to Africa, other parts of Southeast Asia, and islands throughout the Indian and Pacific Oceans. Up to 11 million Chinese (most from the southern provinces) traveled from China to the Straits Settlements, although more than a third of these transshipped to the Dutch Indies, Borneo, Burma, and places farther west. Nearly 4 million traveled directly from China to Thailand; between 2 and 3 million to French Indochina; more than 1 million to the Dutch Indies (for a total of more than 4 million, if transshipments from Singapore are included); and just under 1 million to the Philippines. ${ }^{18}$ At the same time, railroad construction and a relative relaxation of frontiers between Russia and China also led 28-33 million northern Chinese to migrate to Siberia and Manchuria. ${ }^{19}$

Migration within each area increased and interacted with long-distance emigration. Migrants from Ireland traveled to England for work, others moved from eastern and southern Europe to industrial areas in northern Europe, especially France and Germany. In Russia, migrants moved into the growing cities and southern agricultural areas. Within India, they moved to tea plantations in the south and northeast, to the mines and textile-producing regions of Bengal, and to newly irrigated lands and urban areas throughout the subcontinent. ${ }^{20}$

Thus it would be reductive to explain twentieth-century emigration as simply an "expansion of the West" and as the triumph of free labor and free emigration over bondage. To be sure, whole sets of laws in defense of "freedom" were adopted world over. Free migration expanded with the increasing restriction of indenture contracts and their final abolition in 1920. In the United States, the Anti-Peonage Act of 1867 extended the prohibition of servitude (voluntary or involuntary) to all states of the union. The government of India first restricted and then forbade Indian indentured contracts in 1916, while an 1874 agreement between 
the Chinese and Portuguese governments stopped the export of Chinese contract labor from Macao. Chinese authorities investigated the conditions of Chinese migrants in Cuba, Peru, and the United States, which led to the suspension of most of these contracts.

At the same time, formal rules for emigration were not always supported by real legal rights for immigrants once they reached their destination. For example, the conditions of former indentured laborers were extremely different, precisely as they had been for former slaves. The access to landowning that one had on Mauritius and Réunion Island was hardly the rule. Elsewhere, between 1899 and 1938, most of the indentured immigrants served as day laborers in agriculture or commerce; this was the case with Chinese, Indian, and Japanese immigrants in Cuba, British Guiana, Trinidad, and Hawaii. Servant contracts or independent commercial activity were much more widespread in Cuba (40 percent of immigrants) and Hawaii (48 percent) than in British Guiana (8 percent) or Trinidad (24 percent). ${ }^{21}$

Most important, different forms of bondage and debt obligations survived far into the twentieth century. Chinese, Indian, and, to a certain extent, even European emigrants were still subject to disguised forms of indenture contracts and bondage. ${ }^{22}$ The same can be said for Africans, who even if officially freed from slavery, were still under multiple forms of bondage in both intra-African and African-European relations. Local bondage coexisted with the intercontinental flow of free and less-free people. This was the case for various reasons: Labor markets remained highly segmented, as unequal skills added to important institutional constraints. Immigration was never really free; laws and reciprocal and multilateral agreements between powers obtruded and thus regulated the flow. This was the case between European and American states (both northern and southern); between China and Australia and other British Empire destinations; between the American powers, India, and other British colonies; French and British colonies in Africa; the Ottoman Empire and the Western powers; and between Russia, the Ottoman Empire, and the United States.

To summarize, the decline of indentured labor in some areas did not always correspond to the passage from unfree to free migration, insofar as the conditions for the emigration of new generations of Asians and, to a certain extent, Europeans hardly resembled those conjured up in the liberal imagination. Disguised indentured contracts and other forms of bondage persisted in many areas. This trend contrasted with the increasing social protection of some groups of European workers. To a certain extent, these two processes can be seen as complementary, insofar as more social protection and increasing real wages in Europe were supported and 
partially compensated by increasing exploitation of people outside of it. In this context, Russia again displayed a most astonishing evolution.

\section{Russian Growth: From Serfdom to Bondage?}

Here, again, I do not intend to provide a full exposition of a broad topic (Russian growth and social dynamics between 1861 and 1914), but only to summarize some points so as to open the field to future broad analyses on this topic in its relationship with colonial and Western development. Conventional views of prerevolutionary Russia run as follows: Reforms were inadequate and partial; the commune was strong; and industrialization from above was unable to stimulate a wider process. Peasants' well-being decreased while political tensions rose, linked mostly to the discrepancies between economic and social dynamics and political conservatism.

This view has recently been challenged: The global trend of Russia between 1861 and 1914 hardly corresponds to the conventional images that Gershenkron and many others have painted. On the whole, revised population trends show lower mortality and birthrates and better living conditions in the eighteenth and nineteenth centuries than previously thought. ${ }^{23}$ Thus pauperization of the peasantry and frequent famines did not, in fact, take place, ${ }^{24}$ and both agriculture and living standards experienced stable growth during the period extending from 1861 to $1914 .^{25}$

Indeed, this revised analysis is easy to understand when we put it into the broader and long-term perspective developed in the previous chapters. Russian growth during the second half of the nineteenth century was important insofar as it had already been consistent during previous decades and because legal constraints on-and bondage of - the peasantry had already lessened before the official abolition of serfdom in 1861. As a consequence, during the second half of the nineteenth century and up through 1914, the rate of growth and commercialization of Russian agriculture was accelerated. ${ }^{26}$ Between the 1880s and 1900, the grain trade spread capitalism to even the remotest corners of the empire, ${ }^{27}$ and Russia's wheat market was fully integrated into global markets. ${ }^{28}$ Between 1861 and 1914, agriculture's contribution to the national income grew at a rapid pace, comparable to that of contemporary Western European economies. As Gregory evaluated it, Russia experienced rates of growth similar to those of Germany, France, America, Japan, Norway, Canada, and the United Kingdom-1.35 percent average annual productivity growth in agriculture between 1883 and 1887 and between 1909 and 1913, which was three-quarters of the industrial-productivity growth rate and nearly equal to the economy-wide 1.5 percent. ${ }^{29}$ At the same time, 
the share of agriculture in the national income fell over the entire period (1881-1914), from 57 to 51 percent; but most of this decline occurred before Stolypin's privatization of common lands. ${ }^{30}$ As opposed to the conventional view, the rates of labor-productivity growth in agriculture do not appear to have diverged significantly from the economy-wide average. In other words, if we look at the performance of agriculture and the main demographic index, recent estimations show that Russia was not falling behind most advanced countries, rather keeping pace with them.

Growth relied on the evolution of basic Russian institutions-for example, the peasant commune. It is no accident that during the past twenty years, when the history of enclosures in Britain and agriculture in Europe has been revisited, ${ }^{31}$ the image of the Russian commune has been contested as well. Recent estimations made for Russia confirm the lack of any correlation between land redistribution and productivity. ${ }^{32}$

Peasants' possessions more than doubled between the 1870 s and World War One, and acquisitions were made not only by the commune but also increasingly by individual households. Between 1863 and 1872, Russian peasants bought lands to add to their communal allotments. Over three-quarters of all peasant acquisitions on the open market were made by individuals. This trend accelerated with the foundation of the Peasant State Bank, which aimed at encouraging loans to peasants willing to buy lands. Peasant land properties doubled between 1877 and 1905. In 80 percent of the cases, transactions were made by the peasant commune or by peasant associations. During the following years, between 1906 and 1914, the state sold 1.5 million desiatina to peasants ( 1 desiatina equaled 1.1 hectares); landlords lost one-fifth of their land, i.e., 10.2 million out of 49.7 desiatina. Two-thirds of the purchases were made by peasant societies and communes and one-third by individual families. Cossack and peasant ownership increased by 9.5 million desiatina, reaching 170.4 million..$^{33}$ The acquisition of land thus further confirms the argument of increasing peasantry well-being between 1861 and 1914 .

Added to this revised view of Russian agriculture is that of industrialization. In contrast to traditional judgments, between 1881 and 1913 the share of industry in national income rose from 25 to 32 percent. Industrial labor productivity was 28 percent higher than that of agriculture. ${ }^{34}$ However, even if the rate of urbanization has been revised upward, ${ }^{35}$ peasant migrants still accounted for 93 percent of all factory workers in Moscow in 1902, ${ }^{36}$ most of whom worked in textiles. The industry remained geographically concentrated in the central provinces of Moscow and Vladimir, as well as in and around the imperial capital. ${ }^{37}$ This means that despite an increasing rate of urbanization and of regional specialization, the peasant-worker was still the leading figure in 
the Russian economy. According to the 1897 census, 23.3 percent of the active population was employed in nonagricultural sectors, half of which were in proto-industrial and craft activities and the other half of which was in industry and services. Proto-industry and, in particular, rural cottage industry were still serious competitors for urban industry, not only in terms of production, but also on the labor market. ${ }^{38}$ This seems to confirms Olga Crisp's and, more recently, Borodkin's and Leonard's argument that a lack of industrial labor was not due to internal passports or legal constraints on mobility, but to the strength of agriculture, its profitability, and the interest that people had in staying in rural areas and alternating these stays with seasonal urban employment. ${ }^{39}$

Thus the contradictions of this system were related to social relationships rather than to the economy. Mobility, on the one hand, and acquisition of land, on the other hand, weakened the unity of households and the overall economic and social equilibrium linked to it. Because of the social status of the head of the family in peasant communities, young male peasants tended to leave the paternal household early. ${ }^{40}$ Young children and women working and living in towns several months per year were usually reticent to give the head of the household all their income and were also sensitive to urban fashion that called for increasing individual expenditures. ${ }^{41}$ Local courts also registered a growing number of conflicts over these issues between 1870 and World War One. ${ }^{42}$ The number of households rose, therefore, from 8,450,782, in 1877, to $12,019,255$, in 1905 . In fifteen provinces of European Russia, the formation rate of new households was between 30 and 60 percent, in the period of 1861-82. This rate was 2 to 4 times higher than the rate of population growth in these same areas. As a consequence, despite the increasing purchases of land and emigration to Siberia, between 1877 and 1905, land cultivated per family decreased from 13.2 to 10.2 desiatina. In other words, social and economic developments were progressively depriving people of the social umbrella of the extended family and commune. World War One would put a halt to previous economic dynamics and would exasperate social tensions within the village, as well as between peasants and landlords.

To sum up, the evolution of labor laws and the economies of Russia and the Western and colonial worlds were connected. The development of Russia accentuated the crisis of agriculture in Europe and thus emigration across the Atlantic. Russian growth also encouraged an overall restructuring of the European economies, with a stronger integration between agriculture (mechanized) and industry. In turn, this social and economic process helped fuel the evolution of labor law in Europe.

Yet these related processes were not necessarily synonymous with increasing freedom of labor. This outcome and the link between economic 
growth and freedom were true for some groups of workers in Europe, but not for all. Many Russians and certain emigrants from Europe and Asia also benefited from improved living and working conditions. However, for many others, this was not true. More or less disguised forms of bondage persisted in local labor and emigration, in Asia as well as in the Americas, and even more so in colonial Africa. Ultimately, World War One would reintroduce bondage in the very heart of Europe, in Germany, and in the Soviet Union and their annexed territories.

\section{Notes}

1. Joel Mokyr, The Level of Riches (Oxford: Oxford University Press 1990), 114.

2. Eric A. Wrigley, Continuity, Chance and Change: The Character of the Industrial Revolution in England (Cambridge: Cambridge University Press, 1988).

3. Sidney and Beatrice Webb, The History of Trade Unionism, 2nd ed. (London: Longmans, 1911).

4. Hugh Armstrong Clegg, Alan Fox, and A. Thompson, A History of British Trade Unions since 1889, vol. 1 (Oxford: Clarendon Press, 1964).

5. Deakin and Wilkinson, The Law of the Labor Market, 86-87.

6. Gilbert Bentley, The Evolution of National Insurance in Great Britain: The Origins of the Welfare State (London: Joseph, 1966); Jose Harris, Unemployment and Politics: A Study in English Social Policy, 1886-1914 (Oxford: Clarendon Press, 1972).

7. Deakin and Wilkinson, The Law of the Labor Market, 206.

8. Quoted in Deakin and Wilkinson, The Law of the Labor Market, 93.

9. Ibid.

10. Bruno Veneziani, "The Evolution of the Contract of Employment," in The Making of the Labor Law in Europe, ed. Bob Hepple (London: Mansell, 1986), 31-72.

11. Simon Deakin, "Contrat de travail," in Dictionnaire historique de l'économie-droit, XVIIIeXXe siècles, ed. Alessandro Stanziani (Paris: LGDJ, 2007): 289-98.

12. Postel-Vinay, "The Dis-Integration."

13. On this, see among others: Robert Salais, Nicolas Bavarez, and Benedicte Reynaud, Linvention du chômage (Paris: PUF, 1986).

14. Marta Torre-Schaub, Essai sur la construction juridique de la catégorie de marché (Paris: LGDJ, 2002). Alessandro Stanziani, Rules of Exchange: French Capitalism in Comparative Perspective, Eighteenth to Early Twentieth Century (Cambridge: Cambridge University Press 2012).

15. Adam McKeown, "Global Migration, 1846-1940," Journal of World History 15 (2) 2004: 155-89; Donald Treadgold, The Great Siberian Migration: Government and Peasant in Resettlement from Emancipation to the First World War (Princeton: Princeton University Press, 1957): 33-35; Thomas Gottschang and Diana Lary, Swallows and Settlers: The Great Migration from North China to Manchuria (Ann Arbor: University of Michigan, Center for Chinese Studies, 2000), 171.

16. McKeown, "Global Migration."

17. Kevin O'Rourke and Jeffrey Williamson, Globalization and History: The Evolution of a Nineteenth-century Atlantic Economy (Cambridge, MA: MIT Press, 1996).

18. Sandhu, Indians in Malaya.

19. Robert H. G. Lee, The Manchurian Frontier in Ch'ing History (Cambridge, MA, Harvard University Press, 1970). 
20. Arjan de Haan, "Migration on the Border of Free and Unfree Labor: Workers in Calcutta's Jute Industry, 1900-1990," in Migration, Migration History, History: Old Paradigms and New Perspectives, ed. Jan and Leo Lucassen (Bern: Peter Lang, 1999), 197-222.

21. Northrup, Indentured Labor, 150.

22. Ibid.; McKeown, "Global Migration."

23. Steven Hoch, "Famine, Disease and Mortality Patterns in the Parish of Boshervka, Russia, 1830-1932," Population Studies, 52, 3 (1998): 357-68; Steven Hoch, “On Good Numbers and Bad: Malthus, Population Trend and Peasant Standard of Living in Late Imperial Russia," Slavic Review 53, 1 (1994): 41-75; Steven Hoch, "Serfs in Imperial Russia: Demographic Insights," Journal of Interdisciplinary History 13, 2 (1982): 221-46.

24. Stephen Wheatcroft, "Crisis and Condition of the Peasantry in Late Imperial Russia," in Peasant Economy, Culture and Politics of European Russia, 1800-1921, ed. Esther Kingston-Mann and Timothy Mixter (Princeton: Princeton University Press, 1991): 101-27.

25. Elvira M. Wilbur, "Was Russian Peasant Agriculture Really That Impoverished? New Evidence From a Case Study from the 'Impoverished Center' at the End of the Nineteenth Century," Journal of Economic History, 43 (March 1983): 137-44; Esther Kingston-Mann, "Marxism and Russian Rural Development: Problems of Evidence, Experience, and Culture," American Historical Review 84 (Oct. 1981): 731-52; James Y. Simms, Jr., "The Crisis in Russian Agriculture at the End of the Nineteenth Century: A Different View," Slavic Review 36 (Sept. 1977): 377-98; James Simms, "The Crop Failure of 1891: Soil Exhaustion, Technological Backwardness, and Russia's 'Agrarian Crisis," Slavic Review 41 (Summer 1982): 236-50.

26. Paul Gregory, Russian National Income, 1885-1913 (Cambridge: Cambridge University Press, 1982); Alessandro Stanziani, L'économie en revolution. Le cas russe, 1870-1930 (Paris: Albin Michel, 1998); Peter Gatrell, The Tsarist Economy, 1850-1917 (London: Batsford, 1986).

27. Ivan D. Koval'chenko and L. V. Milov, Vserossiiskii agrarnyi rynok, XVIII-nachalo XX $v$. [The all-Russian agrarian market, eighteenth century to the early twentieth century] (Moscow: Nauka1974).

28. Barry K. Goodwin and Thomas J. Grennes, "Tsarist Russia and the World Wheat Market," Explorations in Economic History 35 (1998): 405-30.

29. Gregory, Russian National Income, 126-30, 168-94.

30. Serguei N. Prokopovich, Opyt ischsleniia narodonogo dokboda 50 gubernii Evropeiskoi Rossii $v$ 1900-1913 gg (Study of the national income of 50 provinces of European Russia, 19001913) (Moscow: Sovet Vserossiikikh kooperatvinikh S'ezdov, 1918): 67.

31. Donald McCloskey, "The Open Fields of England: Rent, Risk, and the Rate of Interest, 1300-1815," Markets in History: Economic Studies of the Past. ed. David Galenson (Cambridge: Cambridge University Press, 1989), 5-51; Esther Kingston-Mann, "Peasant Communes and Economic Innovation: A Preliminary Inquiry," in Kingston-Mann and Mixter, Peasant Economy, 23-51; Pavel' N Zyrianov, Krest'ianskaia obshchina Evropeiskoi Rossii 1907-1914 9g. [The Peasant Commune in European Russia, 1907-1914) (Moscow: Nauka, 1992); Judith Pallot, Land Reform in Russia 1906-1917: Peasant Responses to Stolypin's Project of Rural Transformation (Oxford: Clarendon Press, 1999); Cathy Frierson, "Razdel: The Peasant Family Divided," Russian Review 46, 1 (1987): 35-51; Robert Bideleux, "Agricultural Advance Under the Russian Village Commune System," In Land Commune and Peasant Community in Russia: Communal Forms in Imperial and Early Soviet Society, ed. Roger Bartlett (London: MacMillan, 1991), 196-218; Steven Nafziger, "Communal Institutions, Resource Allocation, and Russian Economic Development," unpublished Ph.D. dissertation, Yale University, 2006.

32. Nafzinger, "Communal". .

33. G.Y. Z. i Z., Ezhegodnik ${ }_{7}$ 1907-1916, 10 vols. (Yearbook) (Saint Petersburg, 1908-1916); G.Y.Z.i Z., Obzor dejatel'nosti za .. god, Saint Petersburg 1908-1914. 
34. Gregory, Russian National Income, 132.

35. Gatrell, The Tsarist Economy.

36. Dave Pretty, Neither Peasant nor Proletarian: The Workers of the Ivanovo-Voznesensk Region, 1885-1905, PhD dissertation, Brown University, 1997.

37. Ibid.

38. Gatrell, Russian National Income.

39. Leonard, The Agrarian Reform in Russia.

40. Alessandro Stanziani, L'économie en revolution, 1870-1914 (Paris: Albin Michel, 1998); "The First World War and the Disintegration of Economic Spaces in Russia," in Transforming Peasants: Society, State, and the Peasantry, 1861-1930, ed. Judith Pallot (London: MacMillan 1998): 174-94.

41. Details on conflicts in the province of Vladimir, close to Moscow, in REM (Rossiiskoi etnograficheskii musei), fond 7, opis' 1 .

42. REM, fonds 7, opis' 1; TsSK (Tsentral'nyi Statisticheskii Komitet, Statisticheskiya dannyya o razvodakh $i$ nedeistvitel'nykh brakakh za 1867-1886 (Statistical data on marriages and separations, 1867-1886) (Saint Petersburg, 1893): 16-21. 


\section{REFERENCES}

\section{Archives}

I.4 France

\section{I.4.1 Archives Nationales, Paris}

Series C Parliamentary papers

C 844-58 (inquiries of 1848).

C 1157-61 (inquiries of 1870).

C 846-60 (maximum).

Series F 10 (agriculture and subsistence), 451-2, "Fixation des salaires agricoles," an II, an III.

Series F 12 (Ministry of Trade), 1516-1544.

\section{I.4.2 Archives Départementales de la Réunion (ADR)}

$57 \mathrm{M} 1$. Administration générales du dédpartement.

168 M 3. Elections.

U 339. Justice.

U 349. Justice.

\section{I.4.3 Archives Départementales de Charente Maritime}

Minutier Teuleron, 1638-1680, in particular the groups of documents from 1638, 1641, 1649, 1651, 1666-67, 1670, and 1671. Grozé minutes, 28 May 1692; and the Rivière minutes, 31 May 1684; Ex Moreau minutes, 19 and 25 April 1664.

I.4. 4 Centre des archives d'outre-mer (Aix-en-Provence) CAOM

FM SG/Reu c 370 d 3180.

FM SG/Reu c 379 d 3203, 3211, 3217, 3210.

FM SG/Reu c 380 d 3288.

FM SG/Reu c 382 d 3323, 3324, 3310, 3311, 3318.

FM SG/Reu c 383 d 3323.

FM SG/Reu c 384 d 3341, 3361.

FM SG/ SG Reu c 385 d 3367.

FM SG/Reu c 400 d 3688.

FM SG/Reu c 406, 432 d 4603-4606.

FM SG/ Reu c 454 d 5042-5074.

FM SG/Reu c 514 d 5970. 
FM SG/Reu c 515 d 6005.

FM SG Inde 464, d. 590, letter of 26 February 1848.

\section{I.2 Italy}

Archivio di stato di Genova (ASG), Massaria Caffae, 1374, fol. 1-354.

\section{I.3 Mauritius Island}

Mauritius National Archives

RA (protector of immigrants) 862, 1023, 1264, 1459, 1955, 2205.

HA 66 (poor law, social security, planters' petitions).

\section{I.4 Russia}

Arkhiv gosudarstvennogo soveta (archives of the state council). 5 vols, Saint Petersburg, 1869-1904.

Glavnyi General'nyi Shtab, Materialy dlia geografii i statistiki Rossii, sobrannye ofitserami general'nogo shtaba [Materials for the geography and statistics of Russia, collected by the officers of the General Headquarters], 25 vols. (Saint Petersburg, 1860-1868).

RGADA Rossiikii Gosudastvenny Arkhiv Drevnikh Aktov

(Russian State Archives of Ancient Acts)

fond 89 Turetskie dela, delo 3.

fond 109 Snosheniia Rossii s Bukharoi opis'1, delo 1643.

fond 123 Snosheniia Rossii s Krymom), opis'2, opis' 3, delo 13.

fond 127 Snosheniia Rossii s Nogaiskimi Tatarami.

fond $141 \quad$ Dokumenty tsarskogo arkhiva i posol'skogo prikaza.

fond 199 G. F. Miller.

fonds 210 Razriadnyi prikaz.

fond 248 Senat i senatskie uchrezhdeniia.

fond 291 Glavnyi magistrat, opis' 1, ch. 4, delo 18211.

fond 294 Manufaktor-Kontora, opis-1-3; in particular opis'1, dela 385,386 ; opis'2, dela 135, 145, 168.

fond 342 Komissia o sochinenii novogo ulozheniia 1767, opis' 1, delo 37, part 2 dela $64,119,120$.

fond 350 Revizkie skazki po nizhegorodskoi gubernii, opis' 2, dela 1975 and 2056.

fond 396 Archiv oruzhennoi palaty, opis'1, chasty 1, 2, 4, 5, 7, 11, 24, 26-33, 35,36 , opis'2, ch. 2. ch. 5 (1616-1732), Smolensk, and several other districts.

fond 615 Krepostnye knigi mestnyjh uchrezhdenii XVI-XVIII v, dela 526, 528, $529,4753,6654$.

fond 1209 Prilozhenie arkhiv premikikh votchnikh del, 1565-1692, opis' 1, ch. 1-3, opis'2, ch. 1-2, opisi 16-72.

fond 1239 Pistsovye knigi Moskovskogo Uezda, opis' 3, chast' 17, 69-72, 74, 76, 86-87. 
fond 1252 opis' 1 Abamelek-Lazarevy imeni, gub. Tula

fond 1262 opis' 1, Gagarin imena Saratovkoi i Tambovskoi gub. opis' 20/4; delo 30.

fond 1282 Tolstye-Kristi's Riazanskoi gub.

fond 1287 Sheremetevy, opis' 3, chast 1, delo 107, 117, 1745. opis' 3, chast' 2, delo $1283,1298,1391$.

REM Rossiiskoi etnograficheskii musei, Saint Petersburg.

fond 7 Tenishev archives, opis' 1 (Vladimirskaia guberniia).

RGIA Rossiskii gosudarstvennyi istoricheskii archiv (Russian State Historical Archive)

fond 18 Departament manufaktor i vnutrennei torgovlii opis' 2, delo 1927.

fond 379 Departament gosudarstvennikh imushchestv, opis'1.

fond 1088 Sheremetev, opis' 3, 5, 10: opis' 3, dela 626, 974, 440, 370, 417 ; opis' 10, dela 524, 607,611, 616, 618, 642 .

fond 1149 Department zakonov gosudarstvennogo soveta, opis’ 2, dela 20, 44, 90,125 .

Arkhiv Rossiiskaia Akademiia nauk.

Fond 1714, opis' l (A.A. Novosel'skii), delo 66.

Saltykov-Shchedrin Library in SaintPetersburg, manuscript section, Obshchee sobranie gramot, n. 1727,1937, 1941, 2017, 2019, 2348, 2406, 2635, 2672, 3026, $3081,3392,3475,3486$.

TsGIAM Tsentral'nyi gosudarstvennyi istoricheskii arkhiv gorod Moskvy (Central State Historical Archive of Moscow).

fond 16 Kantseliariia Moskovskogo general-gubernatora, opis' 2, deti soldatov dela $31,40,82,124,146$

fond 32 Glavnyi magistrate, opis' l (1842-66) and opis' 2, 1823-1842.

fond 54 Moskovskoe gubernskoe pravlenie, 1783-1917, opis' 1, dela 56, 284, $966,1509$.

\section{I.5 United Kingdom}

British Library, Additional manuscript 47421, 47428, 47430, and 47432 (Lieven estate, Russia. Instructions).

TNA CO (Colonial Office) series 167 (Mauritius Island): 167/201, 167/202, $167 / 213,167 / 245,167 / 252,167 / 263,167 / 266$.

TNA, CO 415/9/A.221, 1827.

\section{Printed documents}

\section{II.I France}

Bertrand, Louis. Usages locaux du département de la Haute-Loire. Le Puy: Imprimerie de Marchesson, 1865. 
Clément, Henri. Essai sur les usages locaux du Pas-de-Calais. Arras: Topino, 1956.

De Ladeveze, Louis Carrier. Notice sur les usages locaux. Villefranche de Périgord: maison de Dordogne: Sarlat, 1908.

Dumay, Aimé. Usages locaux du département de la Cote d'or. Dijon: Imprimerie E. Jobard, 1884.

Limon, J. M. P. Recueil des usages locaux en vigueur dans le Finistère. Quimper: Imprimerie de Lyon, 1852.

Mosse, Raphaël. Les usages locaux de l'arrondissement d'Orange. Orange: P. Martin, 1914.

Pages, Antoine. Usages et règlements locaux, servant de complément à la loi civile et topographie légale du département de l'Isère. Grenoble: Baratier frères, 1855.

Recueil des usages locaux du département d'Indre-et-Loire. Tours: Guiland Verger, 1863.

Recueil des usages locaux en vigueur dans le département de la Vienne. Poitiers: Bertrand, 1865.

Usages locaux ayant force de loi dans le département de la Meuse. Bar-le-Duc: Imprimerie Contant-Laguerre, 1900.

Watrin, Hyacinthe. Département de l'Eure-et-Loir: usages des quatre arrondissements et notions de droit usuel. Chartres: Lester, 1910.

\section{II.2 Russia and Russian Empire}

Akty istoricheskie, sobrannye $i$ izdannye arkheograficheskoin kommissieiu [Historical documents, collected and published by the Archeographical Commission], 5 vols. Saint Petersburg, 1841-43.

Dokumenty i dogorovnye gramoty velikikh i udel'nykh kniazei XIV-XVI vv. [Documents and acts decreed by princes, fourteenth to sixteenth centuries], edited by L. V. Cherepnin and S. V. Bakhrushin. Moscow: Nauka, 1950.

Kazakbsko-russkie otnosheniia v 16-18 vekakh, Sbornik dokumentov i materialov [The Russian-Kazakh relations during the sixteenth to eighteenth centuries. Collected documents and materials]. Alma-Ata: Akademia nauk Kazakhskoi SSSR, 1961 and 1964.

Materialy dlia istorii krepostnogo prava v Rossii: Izvlecheniia iz sekretnykh otchetov ministerstva vnutrennykh del za 1836-1856 gg [Materials for the history of serfdom in Russia: elements des rapports secrets du ministère des affaires intérieures]. Berlin: Behrs Buchnandlung, 1873.

Materialy po istorii Uzbeksoi, Tadzhiskoi i Turkmenskoi SSR, vol. 1. Leningrad, Moscow: Nauka, 1932.

Materialy po istorii Uzbeskoi, Tadzhikskoi I [Materials for the history of Uzbekistan, Tazhikistan, and Turkmenistan]. Leningrad: AN SSSR, 1932.

Mezhdunarodnye otnosheniia v Tsentral'noi Azii: 17-18vv. Dokumenty I materialy, [International relations in central Asia: seventeenth to eighteenth centuries], 2 vols. Moscow: Nauka, 1989.

Opisanie dokumentov $i$ bumag, khraniashchikhsia $v$ moskovskom arkhive ministerstva iustitsii [Inventory of documents and papers kept in the Moscow archives of the Ministry of Justice], vol. 15. Saint Petersburg: 1908.

Otchet ministerstvo iustitsii za 1845 [Report of the Ministry of Justice, 1845]. Saint Petersburg, 1846.

Pistsovye knigi Moskovskogo gosudarstva [Cadastres of Russia], edited by N. V. Kalachov. Saint Petersburg, 1872 and 1877. 
Polnoe sobranie zakonov Rossiskoi Imperii (hereafter PSZ) [Full collection of laws of the Russian Empire], three series, I: 1649-1825, 46 vols; II: 1830-84, 55 vols.; III:1885-1916, 33 vols: Saint Petersburg.

Russko-dagenstanskie otnosheniia XVII-pervoi chetverti XVIII vv: Dokumenty $i$ materially [Russian-Daghestan relations during the seventeenth through the first quarter of the eighteenth century, documents and materials). Makhachkala: Dagenstanskoe kn. Izd, 1958.

\section{II.3 United Kingdom and the British Empire}

\section{British Parliamentary Papers}

1834 XXVIII, appendix A.

1836 XLIX (166)

1837-78 LII (180)

1840 XXXVII (58), XXXVII (331)

1841 XVI $(45)$

1842 XXX (26)

1844 XXXV (356 and 530)

1846 XXVIII (691 II)

1847 XXXIX (325)

1847-8 XLVI (250)

1849 XXXVII (280)

1854 XLII (2050)

1875 XXXI (704)

Judicial Statistics, England and Wales. Part 1, Criminal Statistics, 1857-1923. London: House of Commons, 1858-1924.

Reports from Committees of the House of Commons, 1st. ser., IX, 1774-1802, 297-538.

\section{Selected Bibliography}

Abélès, Marc. Anthropologie de l'État. Paris: Payot, 1990.

Abu-Lughod, Janet. Before European Hegemony: The World System A.D. 1250-1350. New York: Oxford University Press. 1989.

Adshead, Samuel Adrien. Central Asia in World History. New York: St. Martin's Press, 1993.

Aksakov, Ivan A. Sochinenii (Works), 7 vols. Moscow: Tip. M. G. Volchaninova, $1886-87$.

Alam, Muzaffar. "Trade, State Policy, and Regional Change: Aspects of Mughal-Uzbek Commercial Relations, c. 1550-1750." Journal of Economic and Social History of the Orient 37, no. 3 (1994): 202-27.

Alam, Muzzafar. "Trade, State Policy, and Regional Change." In India and Central Asia. Commerce and Culture, 1500-1800, edited by Scott Levi. Oxford: Oxford University Press, 2007.

Aleksandrov, Viktor A. Sel'skaia obshchina v Rossii, XVIII-nachalo XIXe veka [The rural commune in Russia, eighteenth and early nineteenth centuries]. Moscow: Nauka, 1976. 
Aleppo, Paul of. The Travels of Macarius: Extracts from the Diary of the Travels of Macarius, Patriarch of Antioch. Edited by Lady Laura Ridding. London: Oxford University Press, 1936.

Allen, Richard. Slaves, Freedmen, and Indentured Laborers in Colonial Mauritius. Cambridge: Cambridge University Press, 1999.

Allen, Robert. Enclosures and the Yeoman. Oxford: Clarendon Press, 1992.

Allen, Robert. “Tracking, the Agricultural Revolution in England.” Economic History Review, LII, 2 (1999): 209-235

Alpers, Edward. "The French Slave Trade in East Africa, 1721-1810." Cabiers d'études africaines 10, no. 37 (1970): 80-124.

Alpers, Edward. Ivory and Slaves: Changing Patterns of International Trade in East and Central Africa in the Later Nineteenth Century. Berkeley, Los Angeles: University of California Press, 1975.

Anderson, Clare. Convicts in the Indian Ocean: Transportation from South Asia to Mauritius, 1815-1853. Basingstoke: Macmillan, 2000.

Anisimov, Evgenii.V. Podatnaia reforma Petra I [The fiscal reform of Peter I]. Leningrad: Nauka, 1982.

Antonova, K. A., and Nikolai M. Gol'dberg, eds. Russko-indyskie otnosheniia v XVIII veke: sbornik dokumentov [Russian-Indian relations in the eighteenth century: Collected documents]. Moscow: Nauka, 1965.

Appeleby, Joyce Oldham. Economic Thought and Ideology in Seventeenth-century England. Princeton: Princeton University Press, 1978.

Arrow, Kenneth, Henri Chenery, B. Minhas, and Robert Solow. "Capital-labor Substitution and Economic Efficiency." Review of Economics and Statistics, XLIII (Aug. 1961): 225-50.

Arsen'ev, Konstantin. Statisticheskie ocherki Rossii [Statistical studies of Russia]. Saint Petersburg: Tipografiia Imperatorskoi Akademii Nauk, 1848.

Askarov A. A., ed. Istoriia Uzbekistana tom II: Pervaia polovina XIXe veka [History of Uzbekistan: First half of the nineteenth century]. Tashkent: Fan, 1993.

Aston, Trevor, and Charles Philpin, eds. The Brenner Debate: Agrarian Class Structure and Economic Development in Pre-industrial Europe. Cambridge: Cambridge University Press, 1985.

Austen, Ralph. "The Nineteenth Century Islamic Slave Trade from East Africa (Swahili and Red Sea Coasts): a Tentative Census." Slavery and Abolition 9 (1988): 21-44.

Austen, Ralph. "The Trans-Saharan Slave Trade: A Tentative Census." In The Uncommon Market: Essays in the Economic History of the Atlantic Slave Trade, edited by Jan S. Hogendorn. New York: Academic Press, 1979.

Backhaus, Jürgen G. "Heinrich von Storch's Concept of the Use of Mathematics in Political Economy." Journal of Economic Studies 27, no. 4-5 (2000): 377-81.

Balard, Michel. "Esclavage en Crimée et sources fiscales génoises au XVe siècle.” Byzantinische Forschungen 22 (1996): 9-17.

. Gênes et L'Outre-Mer, I: Les Actes de Caffa du notaire Lamberto di Sambuceto 1289- 1290. Paris, The Hague: Mouton, 1973.

Balbi, Giorgio. “Atti rogati a Caffa da Nicolo' Beltrame (1343-44).” In Notai genovesi in Oltremare: Atti rogati a Caffa e a Licostomo (sec. XIV). Ed. Giorgio Balbi, Stefano Raiteri, Genoa: Collana Storica di Fonti e Studi 14, 1973. 
Balzac, Honoré de. "Lettre sur Kiew, 1847.” In Oeuvres diverses, v. 3, 1836-48. Paris: Louis Conard, 1940: 653-81.

Barendse, Rene J. The Arabian Seas: The Indian Ocean World of the Seventeenth Century. London: M. E. Sharpe, 2002.

Barfield, T. J. The Nomadic Alternative. Englewood Cliffs, N.J.: Prentice Hall, 1993.

Bartlett, Roger. "Serfdom and State Power in Imperial Russia." European History Quaterly 33, no. 1 (2003): 29-64.

Barnsby, George J. Social Conditions in the Black Country, 1800-1900. Wolverhampton, England: Integrated Publishing Services, 1980.

Barrett, Thomas. "Lines of Uncertainty: The Frontier of the North Caucasus." Slavic Review 54, 3 (1995): 578-601.

Barth, Guther Paul. Bitter Strength: A History of the Chinese in the United States, 1850-1870. Cambridge, Mass.: Harvard University Press, 1964.

Bartrip, Peter W., and Sandra Burman. The Wounded Soldiers of Industry: Industrial Compensation Policy, 1833-1897. Oxford and New York: Oxford University Press, 1983.

Bartrip, Peter W. Workmen's Compensation in Twentieth-century Britain: Law, History, and Social Policy. Brookfield, Vt. and Avebury: Aldershot, 1987.

Baudeau, Abbé. "De l'éducation nationale." Éphémérides du citoyen 2, 11 (1767): $165-85$.

Bayly, Christopher. The Imperial Meridian. London: Longman, Pearson Education, 1989.

Beckert, Sven. "Emancipation and Empire: Reconstructing the Worldwide Web of Cotton Production in the Age of the American Civil War." The American Historical Review 109, 5 (2004),1405-38.

Belfanti, Marco. "Rural Manufactures and Rural Proto-industries in the Italy of the Cities from the Sixteenth through the Eighteenth century." Continuity and Change 8 (1993), 253-80.

Belinskii, Vissarion G. Polnoe sobranie sochinenii [Complete works], 13 vols. Moscow: AN SSSR, 1953-59.

Benekendorff, Karl von. Oeconomia forensic oder kurzer Inbegriff derjenigen landwirtschaftlichen Wabreheiten, welchen allen, sowohl hohen als nedrigen Gerichts-Personen zu wissen nothig, 8 vols. Berlin: Pauli, 1784.

Benot, Yves. "Condorcet journaliste et le combat anti-esclavagiste." In Pierre Crépel and Christian Gilain, ed. Condorcet mathématicien, économiste, philosophe et homme politique. Paris: Minerve, 1989: 376-84.

Bentham, Jeremy. "Panopticon": or, the Inspection-House; containing the idea of a new principle of construction applicable to any sort of establishment, in which persons of any description are to be kept under inspection; and in Particular to Penitentiary-houses, Prisons, Houses of industry, Workhouses, Poor Houses, Manufacturies, Madhouses, Lazarettos, Hospitals, and Schools; with a plan of management adopted to the principle; in a series of letters, written in the year 1787, from Crechoff in White Russia, to a friend in England. 2 vols., London: T. Payne, 1791.

- The Correspondence of Jeremy Bentham, 12 vols. Edited by Timothy L. S. Sprigge. London: Athlone Press, 1968-2006.

—. The Panopticon Writings. Edited by Miran Bozevic. London: Verso, 1995. 
The Works of Jeremy Bentham, 11 vols. Edited by John Bowring. Edinburgh: William Tait, 1838-1843.

Benton, Lauren. Law and Colonial Culture. Cambridge: Cambridge University Press, 2002.

Berg, Maxine. The Age of Manufactures, 1700-1820, 2nd edition. London: Routledge, 1994.

Bideleux, Robert. "Agricultural Advance Under the Russian Village Commune System." In Land Commune and Peasant Community in Russia: Communal Forms in Imperial and Early Soviet Society, edited by Roger Bartlett, 196-218. London: Macmillan, 1991.

Biernacki, Richard. The Fabrication of Labor: Britain and Germany, 1640-1914. Berkeley: California University Press, 1995.

Blackburn, Robert. The Overthrow of Colonial Slavery, 1776-1848. London: Verso, 1988.

Blackstone, William. Commentaries on the Laws of England, 4 vols., London: Strahan, Woodfall, 1793-1795.

Blakely, Allison. "American Influences on Russian Reformists in the Era of the French Revolution." Russian Review 52, 4 (1993), 451-71.

Blanchard, Ian. "Le développement économique en perspective historique: l'avenir de la Russie à la lumière de son évolution à l époque moderne (1700-1914)." In Les entreprises et leurs réseaux: hommes, capitaux, techniques et pouvoirs xixe-xxe siècles. Mèlanges en l'honneur de François Caron, edited by Michèle Merger and Dominique Barjot, 381-92. Paris: Presse de l'Université de Paris-Sorbonne, 1998.

- Russia's Age of Silver: Precious Metal Production and Economic Growth in the Eighteenth Century. London and New York: Routledge, 1989.

Bliumin, Iuri Iu. Ocherki ekonomicheskoi mysli pervoi poloviny XIX veka [Studies on the economic thought during the first half of the ninenteenth century]. Moscow and Leningrad: Izdatelstvo Akademii nauk, 1940.

Bloch, Marc. "Serf de la glèbe. Histoire d'une expression toute faite." Revue historique 36 (1921): 220-42.

Blum, Jerome. Lord and Peasant in Russia from the Ninth to the Nineteenth Century. New York: Atheneum, 1964.

- "Prices in Russia in the Sixteenth Century." The Journal of Economic History 16, 2 (1956): 182-99.

Blum, Alain, and Irina Troitskaia. "La mortalité en Russie au XVIIIe et XIXe siècles. Estimations locales à partir des Revizii." Population 51 (1996): 303-28.

Bohac, Rodney. "Everyday Forms of Resistance: Serf Opposition to Gentry Exactions, 1800-1861." In Peasant Economy, Culture, and Politics of European Russia, 1800-1921, edited by Esther Kingston-Mann and Timothy Mixter, 230-60. Princeton: Princeton University Press, 1991.

Bois, Guy. La crise du féodalisme. Paris: Presses de Sciences-Po, EHESS, 1976.

Bonnassie, Pierre. From Slavery to Feudalism. Cambridge: Cambridge University Press, 1991.

Bourquin, Alexandre, Claude Prudhomme, and Hubert Gerbeau. Histoire des petitsblancs à la Réunion. Paris: Karthala, 2005.

Boyer, George. An Economic History of the English Poor Law. Cambridge: Cambridge University Press, 1990. 
Bradley, Joseph. "The Moscow Workhouse and Urban Welfare Reform in Russia." Russian Review 41, 4 (1982): 427-44.

Brass, Tom, and Marcel van der Linden, eds. Free and Unfree Labor: The Debate Continues. Berne: Peter Lang, 1997.

Braudel, Fernand. Civilisation matérielle, économie et capitalism, 3 vols. Paris: Colin, 1977-79.

—_. La Méditerranée et le monde méditerranéen à l’époque de Philippe II. Paris: Colin, 1949.

Bregel, Yuri. "Central Asia in the Twelth to Thirteenth/Eighteenth to Nineteenth Centuries." Encyclopaedia Iranica 5, fasc. 2. Costa Mesa: Mazda, 1992:193-205.

Breman, Jan. Taming the Coolie Beast. Delhi: Oxford University Press, 1989.

Brenner, Robert. "Agrarian Class Structure and Economic Development in Pre-industrial Europe." Past and Present,70 (1976): 30-74.

Bresc, Henri, ed. Figures de l'esclave au Moyen-Âge et dans le monde moderne. Actes de la table ronde organisée les 27 et 28 octobre 1992 par le Centre d'Histoire sociale et culturelle de l'Occident de l'Université de Paris-X Nanterre. Paris: Université Paris X, 1996.

Brill-Olcott, Martha. The Kazhaks. Stanford: Hoover Institutions Press, 1987.

Brower, Daniel. "Urbanization and Autocracy: Russian Urban Development in the First Half of the Nineteenth Century." Russian Review 42, 4 (1983): 377-402.

Bruk, Serguei I., Vladimir M. Kabuzan. "Dinamika chislennosti i rasselenie russkogo etnosa, 1678-1917" (La dynamique du nombre et de l'établissement des ethnies russes, 1678-1917). Sovetskaya istoriografiya,4 (1982): 9-25.

Brunon-Ernst, Anne. "When Foucault Reads Bentham." Paper presented at Annual Meeting of the The Law and Society Association, Berlin, 25 July 2007, http:// www.allacademic.com/meta/p178059_index.html.

Bulletin officiel de lîle de la Réunion, 13 February 1852.

Burbank, Jane. Russian Peasants Go to Court: Legal Culture in the Countryside, 19051917. Bloomington: Indiana University Press, 2004.

Burbank, Jane, and Fred Cooper. Empires in World History. Princeton: Princeton University Press, 2010.

Burton, Audrey. "Russian Slaves in Seventeenth-century Bukhara." In Post-Soviet Central Asia, edited by Touraj Astabaki and John O'Kane, 345-65. London: Taurus Academic Studies, 1998.

Bush, Michael, ed. Serfdom and Slavery: Studies in Legal Bondage. Manchester: Manchester University Press, 1996.

Bushnell, John. "Did Serf Owners Control Serf Marriage? Orlov Serfs and Their Neighbors, 1773-1861." Slavic Review 52, 3 (1993): 419-45.

Bythell, Duncan. The Sweated Trades: Outwork in Nineteenth-century Britain. London: Batsford Academy, 1978.

Campbell, Gwyn. "Madagascar and the Slave Trade, 1810-1895." The Journal of African History 22, 2 (1981): 203-27.

- ed. The Structure of Slavery in Indian Africa and Asia. London: Frank Cass, 2004.

- "Slavery in the Indian Ocean World." In The Routledge History of Slavery, edited by Gad Heuman and Trevor Burnard, 52-63. London: Routledge, 2011. 
Carter, Marina. Servants, Sirdars, and Settlers: Indians in Mauritius, 1834-1874. Delhi: Oxford University Press, 1995.

- "Slavery and Unfree Labor in the Indian Ocean." The History Compass, 4/5 (2006): 800-813.

Cerman, Markus. "The Organization of Production and Trade in Proto-industrial Textile Production in Early Modern East-Central Europe: The Role of Seigniorial Influence and Sub-contracting." In Entrepreneurs and Institutions in Europe and Asia, 1500-2000, edited by Ferry de Goey and Jan Willem Veluwenkamp, 215-36. Aksant: Amsterdam, 2002.

- "Social Structure and Land Markets in Late Medieval Central and Eastern Europe." Continuity and Change 23, l (2008): 55-100.

Chaillou, Virginie. De l'Inde à la Réunion. Histoire d'une transition. L'épreuve du lazaret, 1860-1882. Saint André de la Réunion: Océan éditions, 2002.

Chaudhuri, Kirti N. Asia before Europe: Economy and Civilisation of the Indian Ocean from the Rise of Islam to 1750. Cambridge: Cambridge University Press, 1990.

- Trade and Civilisation in the Indian Ocean: An Economic History from the Rise of Islam to 1750. Cambridge: Cambridge University Press, 1985.

- The Trading World of Asia and the English East India Company, 1660-1760. Cambridge: Cambridge University Press, 1978.

Chakravarti, Utsa. "Of Dasas and Karmakaras: Servile Labor in Ancient India." In Chains of Servitude: Bondage and Slavery in India, edited by Utsa Patnaik and M. Dingawaney, 40-54. New York: Oxford University Press, 1985.

Chekhovich, Oleg D. Bukharkie dokumenty XIV veka [Documents from Bukhara, fourteenth century]. Tashkent: Nauka, 1965.

Chicherin, Boris N. Sobstvennost' i gosudarstvo [Property and the state], 2 vols. Moscow, 1882-83; new edition, Saint Petersburg: Izdatel'stvo Russkoi Khristianskoi gumanitarnoi akademii, 2005.

Christian, David. A History of Russia, Central Asia and Mongolia. Malden: Blackwell, 1998.

Christie, Ian R. The Benthams in Russia, 1780-1791. Oxford: Berg, 1993.

. "Samuel Bentham and the Western Colony at Krichev, 1784-1787." Slavonic and East European Review 48, 111 (1970): 232-47

Clarence-Smith, William Gervase, ed. The Economics of the Indian Ocean Slave Trade. London: Frank Cass, 1989.

- Islam and the Abolition of Slavery. Oxford: Oxford University Press, 2006.

Clark, Gregory. "Factory Discipline." The Journal of Economic History 54, 1 (1994): 128-63.

- "Productivity Growth without Technical Change in European Agriculture Before 1850." The Journal of Economic History 47, 2 (June 1987): 419-32.

- "Why Isn't the Whole World Developed? Lessons from the Cotton Mills." Journal of Economic History 45 (March 1987): 141-74.

Clegg, Hugh Armstrong, Alan Fox, and A. Thompson. A History of British Trade Unions Since 1889, vol. 1. Oxford: Clarendon Press, 1964.

Collins, E. J. T. "Migrant Labor in British Agriculture in Nineteenth Century." Economic History Review 29, 1 (1976): 38-59.

Condillac, Bennot-Etienne, abbé de. Oeuvres de Condillac, 23 vols. Paris: C. Houel, an VI [1798]. 
Confino, Michael. Domaines et seigneurs en Russie vers la fin du XVIIIe siècle: Étude de structures agraires et de mentalités économiques. Paris: Institut d'études slaves de l'Université de Paris, 1963.

—. "Servage russe, esclavage américain." Annales ESC 45, 5 (1990): 1119-41. Systèmes agraires et progrès agricole. L'assolement triennial en Russie au XVIIIeXIXe siècles. The Hague: Mouton, 1969.

Cook, John. Voyages and Travels through the Russian Empire, Tartary, and Part of the Kingdom of Persia. Edinburgh: no publ, 1770.

Cooper, Frederick. Plantation Slavery on the East Coast of Africa. New Haven: Yale University Press, 1977.

Cooper, Frederick, Thomas Holt, Rebecca Scott. Beyond Slavery: Explorations of Race, Labor, and Citizenship on Post-emancipation Societies. Chapel Hill: North Carolina University Press, 2000.

Coornaert, Emile. Les corporations en France. Paris: Gallimard, 1941.

Cottereau, Alain. "Droit et bon droit. Un droit des ouvriers instauré, puis évincé par le droit du travail, France, XIXe siècle." Annales 57, 6 (2002): 1521-57

Crafts, Nicolas R. British Economic Growth during the Industrial Revolution. Oxford: Oxford University Press, 1985.

Craton, Michael. Empire, Enslavement and Freedom in the Caribbean. Kingston: I. Randle Publishers, 1997.

Craven, Paul, and Douglas Hay. "The Criminalization of Free Labor: Masters and Servants in Comparative Perspective." Slavery and Abolition 15, 2 (1994): 71-101.

Crebouw, Yvonne. "Droit et obligations des journaliers et des domestiques, droits et obligations des maîtres." In La moisson des autres, edited by Jean-Claude Farcy and Ronald Hubscher, 181-200. Nice: Créaphys édition, 1996.

- Salaires et salariés agricoles en France, des débuts de la révolution aux approches du XXe siècle. Lille: ANRT, 1986.

Crisp, Olga. "Labor and Industrialization in Russia." In The Cambridge Economic History of Europe, vol. 7, pt. 2, edited by Peter Mathias and Michael Postan. Cambridge: Cambridge University Press, 1978: 308-415.

- Studies in the Russian Economy Before 1914. London: Macmillan, 1976.

Cross, Anthony C. By the Banks of the Neva: Chapters from the Lives and Careers of the British in Eighteenth-century Russia. Cambridge: Cambridge University Press, 1997.

Crowther, M. A. The Workhouse System, 1834-1929: The History of an English Social Institution. Athens, Ga.: Georgia University Press, 1981.

Crummey, Robert. The Formation of Muscovy, 1304-1614. London: Longman, 1987.

- "Sources of Boyar Power in the Seventeenth Century." Cahiers du monde russe and soviétique 34, 1-2, (1993): 107-18.

Custine, Astolphe de. La Russie en 1839, 4 vols. Paris: Amyot, 1843.

Czap, Peter. "The Perennial Multiple-family Household, Mishino, Russia, 17821858. " Journal of Family History (Spring 1982): 5-26.

Dale, Stephen. Indian Merchants and Eurasian Trade, 1600-1750. Cambridge: Cambridge University Press, 1994.

Daniel, Wallace. "Girgorii Teplov and the Conception of Order: The Commission on Commerce and the Role of Merchants in Russia." Canadian-American Slavic Studies 16 (1982): 410-32. 
"The Merchantry and the Problem of Social Order in the Russian State: Catherine II's Commission on Commerce". Slavonic and East European Review, 55 (1977): 185-203.

_ . "The Merchants' View of the Social Order in Russia as Revealed in the Town Nakazy from Moskovskaia Guberniia to Catherine's legislative Commission." Canadian-American Slavic Studies 11 (1977): 503-22.

Davies, Norman. God's Playground: A History of Poland, 2 vol. New York: Columbia University Press, 1982.

Davis, Brian. State, Power, and Community in Early Modern Russia: The Case of Kozlov, 1635-1649. Basingstoke, New York: Palgrave, Macmillan, 2004.

Davis, David Brion. The Problem of Slavery in the Age of Revolution, 1770-1823. New York: Oxford University Press, 1999.

- Slavery and Human Progress. New York: Oxford University Press, 1984.

De la Martinière, Pierre. Voyages dans les pays septentrionaux. Paris: L. Vendame, 1671.

de Madariaga, Isabel. Russia in the Age of Catherine the Great. London: Weidenfeld and Nicholson, 1981.

De Vries, Jan. The Industrious Revolution. Cambridge: Cambridge University Press, 2008

- European Urbanization, 1500-1800. London: Meuthen, 1984.

Deakin, Simon and Frank Wilkinson. The Law of the Labor Market: Industrialization, Employment, and Legal Evolution. Oxford: Oxford University Press, 2005.

Deane, Phyllis, and W. A. Coale. British Economic Growth, 1688-1959: Trends and Structure. Cambridge: Cambridge University Press, 1962.

Debien, Gabriel. Les engagés pour les Antilles 1634-1715. Paris: Société de l'histoire des colonies françaises, 1952.

Dechêne, Louise. Habitants et marchands de Montréal au XVIIe siècle. Paris: Olstrom, 1974.

Deletant, Dennis. "Genoese, Tatars, and Rumanians at the Mouth of the Danube in the Fourteenth Century." The Slavonic and East European Review 62, 4 (1984): $511-30$.

Delort, Robert. "Quelques précisions sur le commerce des esclaves à Gênes vers la fin du XIVe siècle.” Mélanges d'archéologie et d’histoire,78, 1 (1966): 215-50.

Dennison, Tracy. "Did Serfdom Matter? Russian Rural Society, 1750-1860." Historical Research 79, 203 (2003): 74-89.

-The Institutional Framework of Russian Serfdom. Cambridge: Cambridge University Press: 2011.

— Economic History Review 60, 3 (2007): 513-44

Dewerpe, Alain. "En avoir ou pas. A propos du livret ouvrier dans la France du XIXe siècle." In Le travail contraint en Asie et en Europe, XVIIe-XXe siècles, edited by Alessandro Stanziani, 217-40. Paris: MSH éditions, 2010.

- Le monde du travail en France, 1800-1950. Paris: Colin, 1989.

Di Cosmo, Nicolas. "Ancient Inner Asian Nomads: Their Economic Basis and Its Significance in Chinese History." Journal of Asian Studies 53 (1993): 1092-126.

_. "State Formation and Periodization in Inner Asian History." Journal of World History 10 (1999): 1-40. 
Diderot, Denis. "Propriété des terres et agriculture: 4 questions," and "Questions à Catherine II sur la situation économique de l'Empire de Russie." In Diderot et Catherine II, Maurice Tourneux (ed.). Paris: Calmann Lévy, 1899. Reproduced in Denis Diderot. Mémoires pour Catherine II. Edited by Paul Vernière. Paris: Garnier, 1966.

Didry, Claude. Naissance de la convention collective. Paris, EHESS, 2002.

Dmytryshyn, Basil. "Admiral Nikolai Mordvinov: Neglected Russian Liberal." Russian Review 30, 1 (1971): 54-63.

Domar, Evsey, and Michael Machina, "On the Profitability of Russian Serfdom.” The Journal of Economic History 44, 4 (1984): 919-55.

Domat, Jean. Les lois civiles dans leur ordre naturel. Paris: Cognat, 1697.

Dorigny, Marcel and Bernard Gainot. Atlas des esclavages. Paris: Editions autrement, 2006.

Drescher, Seymour, and Stanley Engerman, eds. A Historical Guide to World Slavery. New York, Oxford: Oxford University Press 1998.

Drescher, Seymour. Abolition: A History of Slavery and Antislavery. Cambridge: Cambridge University Press, 2009.

- Capitalism and Antislavery: British Mobilization in Comparative Perspective. New York: Oxford University Press, 1987.

Drew, Ronald. "The Siberian Fair: 1600-1750." The Slavonic and East European Review 39, 93 (1961): 423-39.

Driver, Felix. Power and Pauperism: The Workhouse System, 1834-1884. Cambridge: Cambridge University Press, 1993.

Druzhinin, Nikolai M. Gosudarstvennye krest'iane i reforma P.D. Kiseleva [State peasants and the reform of P. D. Kiselev). Moscow: Nauka 1958.

Duby, Georges. Les trois ordres ou l'imaginaire du féodalisme. Paris: Gallimard, 1978.

Duchet, Michèle. Anthropologie et histoire an siècle des lumières. Paris: Albin Michel, 1971.

Dupré de Saint-Maure, Émile. L'hermite en Russie ou observations sur les moeurs et les usages russes au commencement du XIX siècle, 3 vols. Paris: Pillet ainé, 1829.

Eaton, Henry. "Cadasters and Censuses of Muscovy." Slavic Review 26, 1 (1967): 54-69.

Ekirch, Roger. Bound for America: The Transportation of British Convicts to the Colonies, 1718-1775. Oxford: Clarendon Press, 1987.

Eltis, David. Coerced and Free Migration: Global Perspective. Stanford: Stanford University Press, 2002.

Eltis, David, Stephen Behrendt, David Richardson, and Herbert Klein. The Trans-Atlantic Slave Trade: A Database on CD-Rom. Cambridge: Cambridge University Press, 2000.

Emmer, Pieter C., ed. Colonialism and Migration: Indentured Labor before and after Slavery. Dordrecht, Boston, Lancaster: Martinus Nijhoff, 1986.

Emmons, Terence. The Russian Landed Gentry and the Peasant Emancipation of 1861. Berkeley: University of California Press, 1968.

Engerman, Stanley, ed. Terms of Labor: Slavery, Serfdom, and Free Labor. Stanford: Stanford University Press, 1999.

Entsiklopedicheskii slovar' Brokgauz-Efron [Encyclopaedia Brokgauz-Efron], vol. XVI. Saint Petersburg: Brokgauz, 1895. 
Epstein, Steven. Speaking of Slavery. Ithaca and London: Cornell University Press, 2001.

Esper, Thomas. "Industrial Serfdom and Metallurgical Technology in Nineteenth-century Russia." Technology and Culture 23, 4 (1982): 583-608.

Faccarello, Gilbert. "Galiani, Necker and Turgot: A Debate on Economic Reform and Policy in Eighteenth-century France." In Studies in the History of French Political Economy from Bodin to Walras, edited by G. Faccarello, 120-95. New York and London: Routledge, 1998.

Fall, Babacar. Le travail forcé en Afrique Occidentale Française 1900-1946. Paris: Karthala, 1993.

Farcy, Jean-Claude. Guide des archives judiciaires et pénitentiaires, 1800-1958. Paris: CNRS éditions, 1992.

Farcy, Jean-Claude, and Ronald Hubscher, eds. La moisson des autres. Nice: Créaphys édition, 1996.

Federico, Giovanni. Feeding the World: An Economic History of Agriculture, 18002000. Princeton: Princeton University Press, 2005.

Fedorov, Vladimir A. Pomeshchich'i $i$ krest'iane tsentral'no-promyshlennogo raiona Rossii kontsa XVIII-pervoi poloviny XIXe $v$ [Landlords and peasants in central industrial areas of Russia during the eighteenth to the first half of the nineteenth century]. Moscow: Izdatel'stvo Moskovskogo universiteta, 1974.

Feinstein, Charles. "Capital Formation in Great Britain.” In The Cambridge Economic History of Europe: The Industrial Economies: Capital, Labor and Enterprise, vol. 7, edited by Peter Mathias and Michael Postan, 28-94. Cambridge: Cambridge University Press, 1978.

Feinstein, Charles, and Sidney Pollard, eds. Studies in Capital Formation in the United Kingdom, 1750-1920. Oxford: Clarendon Press, 1988.

Fennell, John. The Crisis of Medieval Russia, 1200-1304. New York: Longman, 1983.

- Ivan the Great of Moscow. London: Macmillan, 1961.

Field, Daniel. The End of Serfdom: Nobility and Bureaucracy in Russia, 1855-1861. Cambridge, Mass.: Harvard University Press, 1976.

- Rebels in the Name of the Tsar. Boston: Houghton Mifflin, 1976.

Finley, Moses. Ancient Slavery and Modern Ideology. New York: Viking Press, 1980.

Fisher, Alan. "Muscovy and the Black Sea Trade." Canadian-American Slavic Studies 6, 4 (1972): 582-93.

—. "The Ottoman Crimea in the Sixteenth Century." Harvard Ukrainian Studies 2 (1981): 141-2.

Foucault, Michel. Surveiller et punir. Naissance de la prison. Paris: Gallimard, 1975. In English translation, Discipline and Punish: The Birth of the Prison, translated by A. Sheridan for Harmondsworth, 1985.

Fraser, Derek. The Evolution of the British Welfare State. London: Palgrave Macmillan, 2009.

Freedland, Mark R. The Contract of Employment. Oxford: Oxford University Press: 1976.

Freedman, Paul, and Monique Bourin, eds. Forms of Servitude in Northern and Central Europe. Turnhout: Brepols, 2005.

Frierson, Cathy. "Razdel: The Peasant Family Divided.” Russian Review 46, 1 (1987): $35-51$. 
Frost, Robert. "The Nobility of Poland-Lithuania, 1569-1795." In The European Nobilities in the Seventeenth and Eighteenth Centuries: Northern, Central and Eastern Europe, vol. 2, edited by Hamish Scott. London: Routledge 1994.

Fuller, William C. Strategy and Power in Russia, 1600-1914. New York: Free Press, 1992.

Fuma, Sudel. De l'Inde du sud à la Réunion. Port-Louis: Graphica 1999.

L'esclavagisme à la Réunion, 1794-1848. Paris: L'Harmattan, 1992.

. Esclaves et citoyens, le destin de 62,000 Réunionnais, histoire de l'insertion des affranchis de 1848 dans la société réunionnaise. Saint-Denis, La Réunion: F.R.D.O.I., 1979

G.Y.Z.i Z. Ezhegodnik, 1907-1916 [yearbook], 10 vols. Saint Petersburg, 1908-1916. G.Y.Z.i Z., Obzor dejatel'nosti za . . , 1908-1914.

Galanter, Marc. Law and Society in Modern India. Delhi: Oxford University Press, 1989. Galenson, David W. White Servitude in Colonial America. Cambridge: Cambridge University Press, 1981.

- "The Rise of Free Labor: Economic Change and the Enforcement of Service Contract in England, 1361-1875." In John James, Mark Thomas, eds. Capitalism in Context: Essays on Economic Development and Cultural Change in Honour of R.M. Hartwell. Chicago: University of Chicago Press, 1994: 114-137.

Gatrell, Peter. The Tsarist Economy, 1850-1917. London: Batsford, 1986.

Gayot, Gérard. De la pluralité des mondes industriels. La manufacture royale des draps de Sedan, 1646-1870. Paris: EHESS, 1995.

Genicot, Louis. Rural Communities in the Medieval West. Baltimore: Johns Hopkins University Press, 1991.

Gentes, Andrew. Exile to Siberia, 1590-1822. Corporal Commodification and Administrative Systematization in Russia. London: Palgrave, 2008.

Gerbeau, Hubert. "Les indiens des Mascaraignes. Simples jalons pour l'histoire d'une réussite (XVIle-XXe siècle)." Annuaire des pays de Indian Ocean, XII (1990-91): 15-45. Éditions du CNRS / Presses universitaires d'Aix-Marseilles, 1992.

Gerbeau, Hubert. "Quelques aspects de la traite illégale des esclaves à Bourbon au XIXe siècle." In Mouvements de populations dans l'Indian Ocean. Paris: Imprimerie Champion, 1979: 273-96.

Gerschenkron, Alexander. Economic Backwardness in Historical Perspective: A Book of Essays. Cambridge, Mass.: Belknap Press of Harvard University Press, 1962.

Gestwa, Klaus. Protoindustrialisierung in Russland. Göttingen: Vandenhoeck and Ruprecht, 1999.

Gilbert, Bentley B. The Evolution of National Insurance in Great Britain: The Origins of the Welfare State. London: Joseph, 1966.

Gilbert, Erik. "Coastal East Africa and the Western Indian Ocean: Long-distance Trade, Empire, Migration, and Regional Unity." The History Teacher 36, 1 (2002): 7-34.

Gioffré, Domenico. Il mercato degli schiavi a Genova nel secolo XV. Genova: Bozzi, 1971.

Gnevushev, A. M. Politiko-ekonomicheskie vzgliady gr. Mordvinova [Mordvinov's political and economic orientations]. Kiev: M. V. Dovnar-Zapol'skii, 1904.

Goldstone, Jack "The Rise of the West or Not? A Revision to Socio-economic History." Sociological theory 18, 2 (2000): 175-94. 
Golitsyn, Mikhail. "Polozhenie dlia krest'ian Efremovskoi votchiny sela Mikhailovskogo derevni Varvarovki 1839 g" [The conditions of peasants of the estate Efremovskii, village of Varvarovki, in 1839]. In Materialy dlia istorii votchonnogo upravleniia v Rossii, edited by M. V. Dovnar-Zapol'skii, 276-80. Kiev: tipography Imperatorskogo Universiteta, n.d.

Gommans, Jos. "The Horse Trade in Eighteenth-century South Asia." Journal of Economic and Social History of the Orient 37, 3 (1994): 228-50.

—. "Mughal India and Central Asia in the Eighteenth Century: An Introduction to a Wider Perspective." Itinerario 15, 1 (1991): 51-70.

- The Rise of the Indo-Afghan Empire, c. 1710-1780. Leiden: Brill, 1995.

Goodwin, Barry K., and Thomas J. Grennes. "Tsarist Russia and the World Wheat Market." Explorations in Economic History 35 (1998): 405-30.

Gopal, Surendra. Indians in Russia in the Seventeenth and Eighteenth Centuries. Calcutta: Naya Prokash, 1988.

Gorshkov, Boris. "Serfs on the Move: Peasant Seasonal Migration in Pre-reform Russia, 1800-1860." Kritika: Explorations in Russian History 1, 4 (2000): 627-56.

Gottschang, Thomas, and Diana Lary. Swallows and Settlers: The Great Migration from North China to Manchuria. Ann Arbor: University of Michigan, Center for Chinese Studies, 2000.

Govindin, Sully-Santa. Les engagés indiens. Saint-Denis la Réunion: Azalées, 1994.

Grantham, George. "Agricultural Supply during the Industrial Revolution: French Evidence and European Implications." Journal of Economic History 49,1 (1989): $43-72$.

. "Divisions of Labor: Agricultural Productivity and Occupational Specialization in Pre-industrial France." The Economic History Review 46, 3 (1993): 478-502.

Grantham, George, and Mary MacKinnon, eds. Labor Market Evolution: The Economic History of Market Integration, Wage Flexibility, and the Employment Relation. London and New York: Routledge, 1994.

Green, David. "Pauper Protests: Protests and Resistance in Early Nineteenth-century London Workhouses.” Social History 31, 2 (May 2006): 137-59.

Gregory, Paul. Russian National Income (1885-1913). Cambridge: Cambridge University Press, 1982.

Grenier, Jean-Yves, and André Orléan. "Michel Foucault, L'économie politique et le libéralisme." Annales HSC 5 (2007): 1155-82.

Grubb, Farley. "The Incidence of Servitude in Trans-Atlantic Migration, 17711804." Explorations in Economic History 22, 3 (1985): 316-39.

. "The Transatlantic Market for British Convict Labor." The Journal of Economic History 60, 1 (2000): 94-122.

Gullickson, Gay. "Agriculture and Cottage Industry: Redefining the Causes of Proto-industrialization." The Journal of Economic History 43, 4 (1983): 831-50.

Gunder Frank, André. The Centrality of Central Asia. Amsterdam: VU University Press, 1992.

Gutton, Jean-Pierre. Domestiques et serviteurs dans la France d'ancien régime. Paris: Aubier, 1981.

Habakkuk, Hrothgar J. American and British Technology in the Nineteenth Century. Cambridge: Cambridge University Press, 1962. 
Hagen, William. Ordinary Prussians: Brandenburg Junkers and Villagers, 1500-1840. Cambridge: Cambridge University Press, 2002.

—. "Subject Farmers in Brandenburg-Prussia and Poland: Village Life and Fortunes under Manorialism in Early Modern Central Europe." In Serfdom and Slavery: Studies in Legal Bondage, edited by Michael L. Bush, 296-310. London and New York: Pearson, 1996.

—. "Village Life in East-Elbian Germany and Poland, 1400-1800." In The Peasantries of Europe, from the Fourteenth to the Eighteenth Centuries, edited by Tom Scott. London: Routledge, 1998.

Hansson, Anders. Chinese Outcast: Discrimination and Emancipation in Late Imperial China. Leiden: Brill, 1996.

Harley, Charles Knick. "British Industrialization before 1841: Evidence of Slower Growth during the Industrial Revolution.” Journal of Economic History 42, 2 (1982): 267-89.

Harnisch, Hartmut. "Bäuerliche Ökonomie und Mentalität unter den Bedingungen der ostelbischen Gutsherrschaft in den letzen Jahrzehnten vor Beginn der Agrarreformen." Jabrbuch für Wirtschaftsgeschichte 24 (1989): 87-108.

Harris, Jose. Unemployment and Politics: A Study in English Social Policy, 1886-1914. Oxford: Clarendon Press, 1972.

Hartley, Janet. "Catherine's Conscience Court-An English Equity Court?” In Russia and the West in the Eighteenth Century, edited by Anthony Cross, 306-18. Newtonville, Mass.: Oriental Research Partners, 1983.

Hasek, Carl William. The Introduction of Adam Smith's Doctrine into Germany. New York: Columbia University Press, 1925.

Hay, Douglas, and Paul Craven, eds. Masters, Servants, and Magistrates in Britain and the Empire, 1562-1955. Chapel Hill: The University of North Carolina Press, 2004.

Hay, Douglas, and Nick Rogers. English Society in the Eighteenth Century: Shuttles and Swords. Oxford: Oxford University Press, 1997.

Heers, Jacques. Esclaves et domestiques au Moyen Age dans le monde méditerranéen. Paris: Hachette, 1996.

Hellie, Richard. Enserfment and Military Change in Muscovy. Chicago: University of Chicago Press, 1971.

—, ed. The Muscovite Law code (Ulozhenie) of 1649, part 1. Irvine, Ca.: Charles Schlacks, 1988.

- Muscovite Society. Chicago: University of Chicago Press, 1967.

"Recent Soviet Historiography on Medieval and Early Modern Russian Slavery." Russian Review 35, 1 (1976): 1-36.

- Slavery in Russia, 1450-1725. Chicago: University of Chicago Press, 1982.

Hennock, E. P. British Social Reform and German Precedents: The Case of Social Insurance, 1880-1914. Oxford: Oxford University Press, 1987.

Hermann, Benedikt Franz Johann. Statistische Schilderung von Russland. Leipzig: Friedrich Gotthold Jacobäer, 1790.

Herzig, Edmund. "The Volume of Iranian Raw silk Exports in the Safavid Period." Iranian Studies 25, 1-2 (1992): 61-79.

Hilaire, Jean. Introduction à l'histoire du droit commerciale. Paris: LGDJ, 1986. 
Hirdermeier, Manfred. Bürgertun und standt in Russland, 1760-1860: Rechtliche Lage und soziale struktur. Cologne: Böhlau, 1986.

__ "Was war das mescantsvo? Zur rechtlichen und sozialen Verfassung des unterenstädticschen Standes in Russland.” Forschungen zur osteuropäschen Geschichte 36 (1985): 15-53.

Hittle, Michael. The Service City: State and Townsmen in Russia, 1600-1800. Cambridge, Mass.: Harvard University Press, 1979.

Hobsbawm, Eric. Industry and Empire. Middlesex: Penguin, 1969.

Hoch, Steven. "Did Russia's Emancipated Serfs Really Pay Too Much for Too Little Land? Statistical Anomalies and Long-tailed Distributions." Slavic Review 63, 2 (2004): 247-74.

Hoch, Steven. "Famine, Disease and Mortality Patterns in the Parish of Boshervka, Russia, 1830-1932.” Population Studies 52, 3 (1998): 357-68.

—. "On Good Numbers and Bad: Malthus, Population Trend and Peasant Standard of Living in Late Imperial Russia." Slavic Review 53, 1 (1994): 41-75.

- Serfdom and Social Control in Russia: Petrovskoe, a Village in Tambov. Chicago: University of Chicago Press, 1986.

—. "Serfs in Imperial Russia: Demographic Insights." Journal of Interdisciplinary History, 13, 2 (1982): 221-46.

Hoch, Steven, and Wilson Augustine. "The Tax Census and the Decline of the Serf Population in Imperial Russia, 1833-1858." Slavic Review 38, 3 (1979): 403-25.

Hoffman, Philip. Growth in a Traditional Society. The French Countryside, 14501815. Princeton: Princeton University Press, 1996.

Hodgson, Marshall. Rethinking World History. Cambridge: Cambridge University Press, 1993.

Huang, Ho Hai. Histoire économique de l'île de la Réunion, 1849-1881: engagisme, croissance et crise. Paris: Lavoisier, 2004.

Huberman, Michael. Escaping from the Market: Negotiating Work in Lancashire. Cambridge: Cambridge University Press, 1996.

"Invisible Handshakes in Lancashire: Cotton Spinning in the First Half of the Nineteenth Century." The Journal of Economic History 46, 4 (Dec. 1986): 987-98.

Iakovlev, Aleksandr' I. Kholopstvo i kholopy v moskovskom gosudarstve XVII v. [Kholopstvo and kholopy in the Russian state, seventeenth century]. Moscow: Nauka, 1943.

Ignatovich, Inna I. Pomeshchich'i krest'iane nakanune osvobozhdeniia [Private landlords' peasants on the eve of emancipation), 2nd edition. Moscow: tipografiia Sytina, 1910; 3rd edition, Leningrad: Gos-Iszadt, 1925.

ILO (International Labour Organization), International Labor Conference, Papers and Proceedings. Geneva, 2001.

Inalcik, Halil, "The Custom Register of Caffa, 1487-1490." In Sources and Studies on the Ottoman Black Sea, vol. 1, edited by Victor Ostapchuk, 92-146. Cambridge, Mass.: Harvard University Press, 1996.

- ed. An Economic and Social History of the Ottoman Empire, 1300-1600, vol. 1. Cambridge: Cambridge University Press, 1997.

- "Servile Labor in Ottoman Empire." In The Mutual Effects of the Islamic and Judeo-Christian Worlds: The East European Patterns, edited by Abraham Ascher, 
Tibor Halasi-Kun, and Bela Kiraly, 25-43. New York: Brooklyn College Press, 1979:

- Sources and Studies on the Ottoman Black Sea: The Custom Register of Caffa, 1487-1990. Cambridge, Mass.: Harvard University Press, 1996.

Indova, Emilia I. Dvortsovoe khoziaistvo v Rossii [The palace economy in Russia]. Moscow: Nauka, 1964.

. "Instruktsiia kniazia M. Shcherbatova prikazchikam ego Iaroslavskikh votchin (1758 g. s dobavleniiami k nei po 1762 g.)" ["Instructions of the prince Shcherbatov adopted in his estate of Iaroslav, 1758-1762]. Materialy po istorii sel'skogo khoziaistva $i$ krest'ianstva SSSR. Sbornik 6. Moscow: AN SSSR, 1965.

—. "O rossiskikh manufakturakh vtoroi poloviny XVIII v." [On the Russian manufactures during the second half of the eighteenth century]. Istoricheskaia geografiia Rossii: XIX-nachalo XX v. Moscow: Nauka, 1975: 248-345.

—. "Rol' dvortsovoi derevni pervoi poloviny XVIII v. v formirovanii russkogo kupechestva" ["The role of the village court during the first half of the eighteenth century in the formation of a Russian bourgeoisie"]. Istoricheskie Zapiski 68 (1961): 189-210; a French translation has appeared as "Les activités commerciales de la paysannerie dans les villages du tsar de la région de Moscou (première moitié du XVIIIe siècle)." Cahiers du monde russe 5, 2 (1964): 206-28.

IPEC. Every Child Counts: New Global Estimates on Child Labor. Geneva: BIT, 2002.

Ivanov, Petr Ivanovich. Alfavitnyi ukazatel' familii i lits, upominaemykh v boiarkikh knigach, khraniashchikhsia v l-m otdelenii moskovskogo arkhiva ministerstva iustitsii [Alphabetical index of families and persons named in the boyari books, conserved in the first section of Moscow's Archives of the Ministry of Justice]. Moscow: Ministerstvo Iustitsii, 1853.

Izmes'eva, Tatiana F. Rossiia v sisteme evropeiskogo rynka. Konets XIXe-nachalo XX $v$. [Russia in the system of the European market, end of the nineteenth to the early twentieth century]. Moscow: Nauka 1991.

Jeannin, Pierre. "La proto-industrialization: développement ou impasse?" Annales ESC, 35 (1980):52-65.

Jones, Eric. Growth Recurring: Economic Change in World History. Ann Arbor: University of Michigan Press, 1988.

Jones, Robert E. The Emancipation of the Russian Nobility, 1762-1785. Princeton: Princeton University Press, 1973.

—. "The Nobility and Russian Foreign Policy, 1560-1811." Cahiers du monde russe et soviétique 34, 1-2 (1993): 159-70.

Jumeer, Musleem. Les affranchissements et les libres à l'ile de France à la fin de l'Ancien Régime, 1768-1789. PhD, Université de Poitiers.

Kabuzan, Vladimir M. Izmeneniia v razmeshchenii naseleniia Rossii v XVIII-pervoi polovineXIX $v$. [Changes in the rate of growth of the Russian population during the eighteenth to the first half of the nineteenth century]. Moscow: Nauka, 1971.

- Narodonaselenie Rossii v XVIII-pervoi polovine XIXe v. [The Russian population, from the eighteenth through the first half of the nineteenth century]. Moscow: Izdatel'stvo Akademii Nauk SSSR, 1963.

Kahan, Arcadius. "Natural Calamities and their Effect Upon the Food Supply in Russia." Jarbücher für Geschichte Osteuropas 16, 3 (1968): 361-71. 
The Plow, the Hammer, and the Knout: An Economic History of Eighteenth-century Russia. Chicago: University of Chicago Press, 1985.

Kaiser, Daniel. The Growth of the Law in Medieval Russia. Princeton: Princeton University Press, 1980.

— - tras. and ed. The Russkaia Pravda: The Expanded Redaction in the Laws of Russia. Series I: The Laws of Rus', Tenth to Fifteenth Centuries. Salt Lake City: Charles Schlacks, Jr., 1992.

Kaiser, Wolfgang, ed. Négociations et transferts. Les intermédiaires dans l'échange et le rachat des captifs en Méditerranée, XVIe-XVIIe siècles. Rome: École française de Rome, 2008.

Kamentseva, Elena I. "Usloviia zakreposhcheniia novoporiadchikov" [The Conditions of Enserfment of New Settlers]. Trudy moskovskogo gosudarstvennogo istoriko-arkbivnogo instituta 7 (1954): 129-54.

Kaplan, Steven L. La fin des corporations. Paris: Fayard, 2001.

Karamzin, Nikolai. "Khronika." Vestnik Evropy (1802): 83-84

Karamazin, Nikolai. Karamzin's Memoir on Ancient and Modern Russia. Edited by Richard Pipes. Cambridge, Mass.: Harvard University Press, 1959.

Karpovich, U. Khoziaistvennye opyty tridtsatiletnei praktiki $i$ nastavlenie dlia upravleniia imeniami [Practices of the three-fields system and the orientation for the direction of domains]. Saint Petersburg: Tip. I. Vorob'eva, 1837.

Kashin, Boris N. Kres'ianskaia promyshlennost' [The peasant rural industry], 2 vols. Moscow and Leningrad: Gos-Izdat, 1935.

Keppen, Petr. Deviataia reviziia: issledovanie o chisle zhitelei v Rossii v 1851 goda [The ninth census: study of the number of inhabitants in Russia in 1851]. Saint Petersburg: Tip. Imp. Akademii nauk, 1857.

Khodarkovsky, Michael. Russia's Steppe Frontier: The Making of a Colonial Empire, 1500-1800. Bloomington and Indianapolis: Indiana University Press, 2002.

Khomiakov, Alexis S. Polnoe sobranie sochinenii, 8 vols. Moscow: Universitetskaia tipografiia, 1900.

Khoroshkevich, Aleksandr' L. Russkoe gosudarstvo v sisteme mezhdunarodnykh otnoshenii kontsa $X V$-nachala $X V I v$. [The Russian state in the system of international relations towards the end of the fifteenth and beginning of the sixteenth century]. Moscow: Nauka, 1980.

Kingston-Mann, Esther. In Search of the True West. Princeton: Princeton University Press, 1999.

- "Marxism and Russian Rural Development: Problems of Evidence, Experience, and Culture." American Historical Review 84 (Oct. 1981):731-52.

Kingston-Mann, Esther, and Timothy Mixter, eds. Peasant Economy, Culture, and Politics of European Russia, 1800-1921. Princeton: Princeton University Press, 1991.

Kirilov, Mikhail V. "Slave Trade in Early Modern Crimea from the Perspective of Christian, Muslim and Jewish Sources." Journal of Early Modern History 11, 1 (2007): 1-32.

Klein, Martin. Breaking the Chain: Slavery, Bondage, and Emancipation in Modern Africa and Asia. Madison: University of Wisconsin Press, 1993.

Kolchin, Peter. "In Defense of Servitude: American Pro-slavery and Russian Pro-serfdom Arguments, 1760-1860." American Historical Review 85, 4 (1980): 809-27. 
. Unfree Labor: American Slavery and Russian Serfdom. Cambridge, Mass.: Belknap Press of Harvard University Press, 1987.

Kollmann, Nancy. By Honor Bound: State and Society in Early Modern Russia. Ithaca and London: Cornell University Press, 1999.

Kolycheva, Evgeniia I. Kholopstvo i krepostinichestvo, konets XV-XVI vek [The kholopy and enserfment, end of the fifteenth century to sixteenth century]. Moscow: Nauka, 1971.

Kopanev, Alexander' I. "Naselenie Russkogo gosudarstva v XVI v" [The population of the Russian state in the sixteenth century]. Istoricheskie zapiski 64 (1959): 233-54.

Koval'chenko, Ivan D. Russkoe krepostnoe krest'ianstvo v pervoi polovine XIX v. [The Russian serf economy during the first half of the nineteenth century]. Moscow: Nauka, 1967.

Koval'nchenko, Ivan D., and L.V. Milov. Vserossiskii agrarnyi rynok XVIII-nachala $X X \nu$. [The all-Russian agrarian market, eighteenth century to the early twentieth century]. Moscow: Nauka, 1974.

Kukanova, Nina G. Ocherki po istorii russko-iranskikh torgovykh otnoshenii v XVII-pervoi polovine XIXev veka [Studies on the Russian-Iranian relations in the seventeenth to the first half of the nineteenth century]. Saransk: Mordovskoe knizhnoe izd-vo, 1977.

Kula, Witold. An Economic Theory of the Feudal System. London: New Left Books, 1976.

Kussmaul, Anne. Servants in Husbandry. Cambridge: Cambridge University Press, 1981.

Kuznets, Simon. Seasonal Variations in Industry and Trade. New York: NBER, 1933.

Labrouquère, André. Les idées coloniales des physiocrates. Paris: Presses Universitaires de France, 1927.

Lamarche Marrese, Michelle. “The Enigma of Married Women's Control of Property in Eighteenth-century Russia." Russian Review 58, 3 (1999): 380-95.

Larson, Pier. "African Diasporas and the Atlantic." In The Atlantic in Global History, 1500-2000, edited by Jorge Canizares-Esguerra and Erik Seeman, 129-147. Upper Saddle River: Pearson Prentice Hall, 2007

Laserson, Max. The American Impact on Russia: Diplomatic and Ideological, 17841914. New York: Macmillan, 1950.

Laslett, Peter. The World We Have Lost. New York: Metheun, 1965.

Le Goff, Jacques. Du silence à la parole. Rennes: Presses Universitaires de Rennes, 2004.

Le Moniteur de la Réunion, 3 July 1852.

Le Play, Frédéric. Voyages en Europe, 1829-1854. Paris: Plon, 1899.

Ledovskaia, Irina V. "Biudzhet russkogo pomeshchika v 40-60kh godakh XIX v" [Estate owners' budgets in the 1840s-1860s]. In Akademiia Nauk SSSR. Materialy po istorii sel'skogo khoziaistva $i$ krest'ianstva SSSR, vol. 8. Moscow: Nauka 1974: 240-245.

Lee, Robert H. G. The Manchurian Frontier in Ch'ing History. Cambridge, Mass.: Harvard University Press, 1970.

Leonard, Carol. Agrarian Reform in Russia. Cambridge: Cambridge University Press, 2011. 
Reform and Regicide: The Reign of Peter III of Russia. Bloomington: Indiana University Press, 1993.

Leont'ev, Aleksei K. Obrazovanie prikaznoi sistemy upravleniia v russkom gosudarstve. $I z$ istorii sozdaniia tsentralizovannogo gosudarstvennogo apparata v kontse $X V$-pervoi polovine XVI $v$. [The formation of chancellery system in the Russian state: history of the formation of the centralized state, fifteenth and sixteenth centuries]. Moscow: Moskovskii Universitet, 1961.

Lequin, Yves, and Pierre Delsalle. La brouette et la navette: tisserands, paysans et fabricants dans la région de Roubaix et de Tourcoing, 1800-1848. Lille: Westhoek, 1985.

Leventer, Herbert. "Comments on Richard Hellie" Russian Review 36, 1 (1977): 64-67.

Levi, Scott. "Hindus beyond the Hindu Kush: Indians in the Central Asian Slave

Trade." Journal of the Royal Asiatic Society 12, 3 (2002): 277-88.
. "India, Russia, and the Eighteenth-century Transformation of the Central Asian Caravan Trade." Journal of Economic and Social History of the Orient 42, 4 (1999): 519-48.

- The Indian Diaspora in Central Asia and Its Trade, 1550-1900. Leiden: Brill, 2002.

Lewis, Frank. "The Cost of Convict Transportation from Britain to Australia, 17961810." Economic History Review XLI, 4 (1988): 507-24.

Lindert, Peter, and Jeffrey Williamson. "English Workers' Living Standards during the Industrial Revolution. A New Look." Economic History Review 36, 1 (1983): $1-25$.

—. "Revising England's Social Tables, 1688-1867." Explorations in Economic History 19, 4 (1982): 385-408.

Lopez, Roberto Sabatino. The Commercial Revolution of the Middle Ages, 950-1350. New York: Cambridge University Press, 1972.

Lortholary, Albert. Le mirage russe en France au XVIII siècle. Paris: Éditions contemporaines, 1948.

Lovejoy, Paul. The Ideology of Slavery in Africa. Beverly Hills: Sage, 1981.

- Transformations in Slavery: A History of Slavery in Africa. Cambridge: Cambridge University Press, 1983.

Lovejoy, Paul, and Toyin Fayola, eds. Pawnship, Slavery, and Colonialism in Africa. Asmara: Africa World Press, 2003.

Lucassen, Jan, and Leo Lucassen, eds. Migration, Migration History, History: Old Paradigms and New Perspectives. Berne: Peter Lang, 1997.

MacLeod, Christine. Inventing the Industrial Revolution. Cambridge: Cambridge University Press, 1988.

Macpherson, Crawford B. The Political Theory of Possessive Individualism. Oxford: Oxford University Press, 1962.

Maestri, Edmund, ed. Esclavage et abolition dans l' Océan Indien, 1723-1869. Paris: L'Harmattan, 2002.

Maillard, Louis. Notes sur l'île de la Réunion. Paris: Dentu, 1862.

Man'kov, Arkadii. Razvitie krepostonogo prava v Rossii vo vtoroi polovine XVII veka [The development of serfdom in Russia during the second half of the seventeenth century]. Leningrad: Nauka 1962. 
Tseny I ikh dvizhenie v russkom gosudarstve XVI veka [Prices and their dynamics in the Russian state in the sixteenth century]. Moscow, Leningrad: Nauka, AN SSSR, 1951.

- Ulozhenie 1649. Kodeks feodal'nogo prava Rossii [The legal code of 1649: the code of feudal law in Russia]. Leningrad: Nauka, 1980.

Marimoutou, Michèle. Les engagés du sucre. Saint-Denis La Réunion: Éditions du tramail, 1999.

Martin, Esmond, and B. T.C. Ryan. "A Quantitative Assessment of the Arab Slave Trade of East Africa, 1770-1896." Kenya Historical Review 5, 1 (1977): 71-91.

Martin, Virginia. Law and Custom in the Steppe: The Kazakhs of the Middle Horde and Russian Colonialism in the Nineteenth Century. Richmond, Surrey: Routledge Curzon, 2001.

May, Jean-Baptiste. Saint-Pétersbourg et la Russie en 1829, 2 vols. Paris: Levasseur, 1830.

Mayaud, Jean-Luc. "Salariés agricoles et petite propriété dans la France du XIXe siècle." In La moisson des autres, edited by Jean-Claude Farcy and Ronald Hubscher, 29-56. Nice: Créaphys édition, 1996.

Maza, Sara. Servants and Masters in Eighteenth-century France. Princeton: Princeton University Press, 1983.

McCaffray, Susan P. "What Should Russia Be? Patriotism and Political Economy in the Thought of N. S. Mordvinov." Slavic Review 59, 3 (2000): 572-96.

McCloskey, Donald. "The Open Fields of England: Rent, Risk, and the Rate of Interest, 1300-1815." In Markets in History: Economic Studies of the Past, edited by David Galenson, 5-51. Cambridge: Cambridge University Press, 1989.

McGrew, Roderick E. "Dilemmas of Development: Baron Heinrich Storch, 17661835, on the Growth of Imperial Russia." Jahrbücher für Geschichte Osteuropas 24, 1 (1976): 31-71.

McKenna, Timothy M. Muslim Rulers and Rebels. Everyday Politics and Armed Separatism in the Southern Philippines. Berkeley: University of California Press, 1998.

McKeown, Adam. “Global Migration, 1846-1940.” Journal of World History 15 (2) 2004: 155-89.

McKinlay, Alain, and Ken Starkey, eds. Foucault, Management and Organization Theory: From Panopticon to Technologies of Self. London: Sage Publications, 1998.

Meillassoux, Claude. Anthropologie de l'esclavage. Paris: Presses Universitaires de France, 1986.

Mel'nitskii, Nikolai. Sbornik svedenii o voenno-uchebnykh zavedeniiakhv Rossii [Collection of figures on the military establishments in Russia], 4 vols. Saint Petersburg, $1857-1860$.

Melton, Edgar. "Enlightened Seigniorialism and Its Dilemma in Serf Russia, 17501830.” Journal of Modern History 62, 4 (1990): 675-708.

- "Population Structure, the Market Economy, and the Transformation of Gutscherrschaft in East Central Europe, 1650-1800: The Case of Brandenburg and Bohemia." German History 16, 3 (1998): 297-324.

- "Proto-industrialization, Serf Agriculture, and Agrarian Social Structure.:Two Estates in Nineteenth-century Russia." Past and Present, 115 (May 1987): 73-81. 
. "The Russian Peasantries, 1450-1860." In The Peasantries of Europe, edited by Tom Scott, 227-68. London: Longman 1998.

Miers, Suzanne. "Contemporary Forms of Slavery." Canadian Journal of African Studies 34, 3 (2000): 714-47. (Special issue: On Slavery and Islam in African History: A Tribute to Martin Klein)

Miers, Suzanne, and Igor Kopytoff, eds. Slavery in Africa: Historical and Anthropological Perspectives. Madison: University of Wisconsin Press, 1977.

Miers, Suzanne, and Richard Roberts, eds. The End of Slavery in Africa. Madison: University of Wisconsin Press, 1988.

Miller, Joseph Calder. Slavery and Slaving in World History: A Bibliography, 19001996. Armonk, N.Y.: M. E. Sharpe, 1999.

Minard, Philippe. La fortune du colbertisme. Etat et industrie dans la France des Lumières. Paris: Fayard, 1998.

Mirabeau, Victor Riqueti. L'ami des hommes, ou Traité de la population. Avignon: no publ., 1758.

Mironenko, Serguei V. Samoderzhavie $i$ reformy: politicheskaia bor'ba $v$ Rossii $v$ nachale XIX $v$. [Autocracy and reforms: political struggle in Russia in the early nineteenth century]. Moscow: Nauka, 1989.

Mironov, Boris. "Consequences of the Price Revolution in Eighteenth-century Russia." The Economic History Review 45 (1992): 457-78.

- "The Economic Structure of Russian Towns in the Second Half of the Eighteenth and the First Half of the Nineteenth Centuries." Historical Social Research 16, 2 (1991): 128-43.

—. "Russkii gorod vo vtoroi polovine XVIII-pervoi polovine XIXe veka: tipologicheskii analiz" ["The Russian town during the second half of the eighteenth century to the first half of the nineteenth century: typological analysis"]. Istoriia SSSR 5 (1988):150-68.

- Russkii gorod v 1740-1860 gody [The Russian town during the years 17401860]. Leningrad: Nauka: 1990.

- The Social History of Russian Empire, 2 vols. Boulder, CO: Westview, 1999.

- Vnytrennii rynok Rossii vo vtoroi polovine XVIII -pervoi po-lovine XIX v. [The domestic market in Russia during the second half of the eighteenth century to the first half of the nineteenth century]. Leningrad: Nauka, 1981.

Mironov, Boris, and Carol Leonard. "In Search of the Hidden Information: Some Issues in the Socio-Economic History of Russia in the Eighteenth Century and Nineteenth Century." Social Science History 9, 4 (1985): 339-59.

Mokyr, Joel. The Lever of Riches. Oxford: Oxford University Press, 1990.

Montefiore, Simon Sebag. Prince of Princes: The Life of Potemkin. London: Phoenix Press, 2001.

_. "Prince Potemkin and the Benthams: The Project to Create an English Village with Modern Factories in Belorussia." History Today 52, 8 (Aug. 2003): $38-43$.

Montesquieu, Charles Secondat, baron de. Esprit des lois. Paris: Garnier, 1967, orig. 1748.

Moon, David. The Abolition of Serfdom in Russia, 1762-1907. New York: Longman, 2001. 
. "Peasant Migration and the Settlement of Russian Frontiers, 1550-1897." The Historical Journal 40, 4, 1997: 859-93.

- The Russian Peasantry, 1600-1930: The World the Peasants Made. London and New York: Addison Wesley Longman, 1999.

- "Reassessing Russian Serfdom.” European History Quarterly 26, 1 (1996): 483-526.

Mordvinov, Nikolai S. "Nekotoriia soobrazheniia po predmetu manufaktur v Rossii i o tarife," ["Some observations on Russian manufactures and the tariffs"]. Zhurnal Departamenta Gosudarstvennoi ekonomiki 14 (30 Dec. 1815): 282-303, 345-88.

Morgan, Gwenda, and Peter Rushton, eds. Eighteenth Century Criminal Transportation: The Formation of the Criminal Atlantic. Basingtoke: Palgrave Macmillan, 2004.

Morgan, Kenneth. “Convict Runaways in Maryland, 1745-1775.” Journal of American Studies 23, 2 (1989): 253-68.

Moriakov, Vladimir I. Iz istorii evoliutsii obshchestvenno-politicheskikh vzgliadov prosvetitelei kontsa XVIII veka: Reinal' $i$ Radishchev [On the history of the evolution of the social-political orientations of institutors during the eighteenth century: Raynal and Radishchev]. Moscow: Izdatel'stvo Moskovskogo Universiteta, 1981.

Moriceau, Jean-Marc. "Les Baccanals ou grèves des moissonneurs en pays de France, seconde moitié du XVIIIe siècle.” In Mouvements populaires et conscience sociale, edited by Jean Nicolas, 420-433. Paris: Maloine, 1985.

Morrison, Daniel. "Trading Peasants" and Urbanization in Eighteenth Century Russia: The Central Industrial Region. Longman: New York and London, 1987.

Morrison, Kathryn. The Workhouse: A Study of Poor-law Buildings in England. Exeter: Royal Commission on the Historical Monuments of England, 1999.

Munro, John. "Crisis and Change in Late Medieval English Economy." Journal of Economic History 58, 1 (1998): 215-19.

Nafziger, Steven. Communal Institutions, Resource Allocation, and Russian Economic Development. Ph. D. dissertation, Yale University, 2006.

Naidu, Sureh, and Noam Yuchtman. "How Green Was My Valley? Coercive Contract Enforcement in Nineteenth-century Britain.” NBUR working papers, 2009 and 2010. tuvalu.santafe.edu/ bowles/GreenValley.pdf

Nicholas, Stephen, ed. Convict Workers: Reinterpreting Australia's Past. Cambridge: Cambridge University Press, 1989.

North, Douglass. Structure and Change in Economic History. New York: Norton, 1981.

North, Michael. From the North Sea to the Baltic: Essays in Commercial, Monetary and Agrarian History, 1500-1800. Aldershot: Ashgate, 1996.

Northrup, David. Indentured Labor in the Age of Imperialism, 1834-1922. Cambridge: Cambridge University Press, 1995.

Novikov, Nikolai I. Izbrannye sochineniia [Selected works]. Moscow: Gosudarstvennoe izdatel'stvo khudozhestvennoi literatury, 1951.

Novosel'skii, Aleksei. Bor'ba Moskovskogo gosudarstva s tatarami p pervoi polovine 17 veka [The fight of the Muscovite state against the Tatars during the first half of the seventeenth century]. Moscow and Leningrad: Nauka, 1948. 
O' Brien, Patrick. "Agriculture and the Industrial Revolution." Economic History Review 30, 1 (1977): 166-81.

O'Rourke, Kevin, and Jeffrey Williamson. Globalization and History: The Evolution of a Nineteenth-century Atlantic Economy. Cambridge, Mass.: MIT Press, 1996.

Ogilvie, Sheilagh. "Guild Efficiency and Social Capital." Economic History Review, LVII (2004): 286-333.

Ostrowski, Donald. Muscovy and the Mongols: Cross-cultural Influences on the Steppe Frontier, 1304-1589. Cambridge: Cambridge University Press, 1998.

Poni, Carlo. "Per la storia del distretto serico di Bologna, secoli XVI-XIX." Quaderni storici, 73 (1990): 93-167.

. "The Economic World of the Bohemian Serf." Economic History Review, LIV (2001): 430-453.

—, and Markus Cerman, eds. European Proto-industrialization. Cambridge: Cambridge University Press, 1996.

Pallot, Judith. Land Reform in Russia, 1906-1917: Peasant Responses to Stolypin's Project of Rural Transformation. Oxford: Clarendon Press, 1999.

Pamuk, Sevket. "The Black Death and the Origin of the Great Divergence across Europe, 1300-1600." European Review of Economic History I (2007): 289-317.

Paneiakh, Viktor. Kabal'noe kbolopstvo na Rusi v XVI veke [Temporary limited servants in Russia in the Sixteenth century]. Leningrad: Nauka, 1967.

- Kholopstvo v pervoi polovine XVII veke [Kholopstvo in the first half of the seventeenth century]. Leningrad: Nauka, 1984.

_. "Ulozhenie 1597 g. o kholopstve" [Ulozhenie of 1597 on kholopstvo]. Istoricheskie Zapiski 77 (1955): 154-89.

Panero, Francesco. Schiavi, servi e villani nell'Italia medievale. Turin: Paravia, 1999.

Patnaik, Utsa, and M. Dingawaney, eds. Chains of Servitude: Bondage and Slavery in India. New York: Oxford University Press, 1985.

Patterson, Orlando. Slavery and Social Death: A Comparative Study. Cambridge: Cambridge University Press, 1982.

Pearson, Michael N. Port Cities and Intruders, the Swahili Coast, India, and Portugal in the Early Modern Era. Baltimore: Johns Hopkins University Press, 1998.

Pease-Watkins, Catherine. "Bentham's Panopticon and Dumont's Panopticon," University College London, Bentham project, www.ucl.ac.uk/bentham-project.

Perdue, Peter. China Marches West:The Qing Conquest of Central Eurasia. Cambridge, Mass.: Belknap Press of Harvard University Press, 2005.

"Military Mobilization in Seventeenth and Eighteenth Century China, Russia, and Mongolia." Modern Asian Studies 30, 4 (1996): 757-93.

Perrot, Jean-Claude. Histoire intellectuelle de l'économie politique. Paris: EHESS, 1992.

Perry, John. État présent de la grande Russie. The Hague: H. Dusanzet, 1717.

Pétré-Grenouilleau, Olivier. Les traites négrières. Paris: Gallimard, 2004.

Pintner, Walter M. Russian Economic Policy under Nicholas I. Ithaca: Cornell University Press, 1967.

Pipes, Richard. "The Russian Military Colonies." Journal of Modern History 22, 3 (1950): 205-19.

Pistarino, Giorgio. Notai genovesi in Oltremare. Atti rogati a Chilia da Antonio di Ponzo (1362-69). Genoa: Collana Storica di Fonti e Studi, 13, 1971. 
Pleshcheev, Serguei I. Obozrenie Rossiiskaia imperii v nyneshnem eia novoustroennom sostoianii [Description of the Russian Empire in its present condition]. Saint Petersburg, 4 volumes, 1786, 1787, 1790, 1793.

Poe, Marhall. "What Did Russians Mean When They Called Themselves Slaves of the Tsar?" Slavic Review 57, 3 (1998): 585-608.

Polanyi, Karl. The Great Transformation. Boston: Beacon Press, 1957.

Pomeranz, Kenneth. The Great Divergence. Princeton: Princeton University Press, 2000. Poovey, Mary. A History of Modern Fact. Chicago: University of Chicago Press, 1998. Portal, Roger. "The Industrialization of Russia." In The Cambridge Economic History of Europe, v. 6, pt. 2, edited by H. J. Habakkuk and M. M. Postan. Cambridge: Cambridge University Press, 1966-89.

Postan, Michael. "The Chronology of Labor Services." Transactions of the Royal Historical Society 20 (1937): 169-93.

Postel-Vinay, Gilles. "The Dis-integration of Traditional Labor Markets in France: From Agriculture and Industry to Agriculture or Industry." In Labor Market Evolution, edited by George Grantham and Mary MacKinnon, 64-83. London and New York: Routledge, 1994.

Pothier, Robert-Joseph. Traité du contrat de lonage. Paris: Débure père, 1771.

Pouwels, Randall. "Eastern Africa and the Indian Ocean to 1800: Reviewing Relations in Historical Perspective." The International Journal of African Historical Studies 35, 2/3 (2002): 385-425.

Prakash, Gyan. "Terms of Servitude: The Colonial Discourse on Slavery and Bondage in India." In Breaking the Chains: Slavery, Bondage and Emancipation in Modern Africa and Asia, edited by Martin Klein, 131-49. Madison: University of Wisconsin Press, 1986.

Prakash, Gyan. Bonded Histories: Genealogies of Labor Servitude in Colonial India. Cambridge: Cambridge University Press, 1990.

Pravilova, Ekaterina A. Zakonnost' $i$ prava lichnosti: administrativnaia iustitsiia v Rossii, vtoraia polovina XIX v.-oktiabr' 1917 [Legality and the rights of the person: administrative justice in Russia, in the second half of the nineteenth century to October 1917]. Saint Petersburg: Izd-vo SZAGS, 2000.

Pretty, Dave. Neither Peasant nor Proletarian: The Workers of the Ivanovo-Voznesensk Region, 1885-1905. Ph.D., Brown University, 1997.

Prokopovich, Serguei N. Opyt ischsleniia narodonogo dokhoda 50 gubernii Evropeiskoi Rossii v 1900-1913 gg [Study on the national income of 50 provinces of the European Russia, 1900-1913]. Moscow: Soviet Vserossiikikh kooperatvinikh S'ezdov, 1918.

Prokof'eva, Lidia S. Krest'ianskaia obshchina v Rossii vo vtoroi polovine XVIII-pervoi polovine XIX $v$ [The peasant commune in Russia during the second half of the eighteenth century to the first half of the nineteenth century]. Leningrad: Nauka, 1981.

Quang, Ho Hai. Histoire économique de l'île de la Réunion, 1849-1881: engagisme, croissance et crise. Paris: Lavoisier, 2004.

Raeff, Marc. "State and Nobility in the Ideology of M. M. Shcherbatov." American Slavic and East European Review 19, 3 (1960): 363-79.

Raeff, Marc. The Well-ordered Police State: Social and Institutional Change Through Law in the Germanies and Russia, 1600-1800. New Haven: Yale University Press, 1983. 
Raynal, Guillaume-Thomas. Histoire philosophique et politique des établissemens et du commerce des Européens dans les deux Indes, 10 vols. Neuchâtel and Geneva: Librairies associées, 1780.

Régent, François. La France et ses esclaves. Paris: Grasset, 2007.

Reid, Anthony. Slavery, Bondage, and Dependency in South-East Asia. London: Macmillan, 1984.

Renault, François. "L'abolition de l'esclavage au Sénégal. L'attitude de l'administration française 1848-1905." Revue française d'histoire d'outre-mer 58, 1 (1971): $5-80$.

- Libération d'esclaves et nouvelle servitude: les rachats de captifs africains pour le compte des colonies françaises après l'abolition de l'esclavage. Abidjan: Les nouvelles éditions africaines, 1976.

Riazul, Islam. Indo-Persian Relations. Teheran: Iranian Culture Foundation, 1970.

Romeo, Paul. "Heinrich Storch, Adam Smith, and the Question of Russian Economic Development." M.A. thesis, University of North Carolina, 1996.

Roncaglia, Alessandro. Petty: The Origins of Political Economy. Armonk, N.Y.: M. E. Sharpe, 1985.

Rosenberg, Hans. Bureaucracy, Aristocracy, and Autocracy: The Prussian Experience, 1660-1815. Cambridge, Mass.: Harvard University Press, 1966.

Rospisnoi spisok goroda Moskvy 1638 goda [Lists of the town of Moscow in 1638]. Moscow: Tipografiia Moskovskogo universiteta, 1911.

Rossabi, Morris. China and Inner Asia from 1368 to the Present Day. London: Thames and Hudson, 1975.

Rouet, Gilles. Justice et justiciables au XIX et XX $X^{e}$ siècles. Paris: Belin, 1999.

Rozental', V. N. "Obshchestvenno-politicheskaia programma russkogo liberalizma v seredine 50-kh godov XIXe veka." ( The political-social programm of Russian liberalism, mid 1850s) Istoricheskie zapiski 70 (1961): 197-222.

Rozier, Abbé. Cours complet d'agriculture on Dictionnaire universel d'agriculture. Paris: Clouzier, 1789.

Rubinshtein, Nikolai L. Sel'skoe khoziaistvo Rossii vo vtoroi polovine XVIII v. [Russian agriculture during the second half of the eighteenth century]. Moscow: Nauka, 1957.

Rudolph, Richard, ed. The European Peasant, Family, and Society: Historical Studies. Liverpool: Liverpool University Press, 1995.

Rudolph, Robert. "Agricultural Structure and Proto-industrialization in Russia: Economic Development with Unfree Labor." The Journal of Economic History 45 (1985): 47-69.

Ryndziunskii, Pavel G. Gorodskoe grazhdanstvo doreformennoi Rossii [Urban citizenship in Russia before the reforms]. Moscow: Nauka, 1958.

. "Melkaia promyshlennost' (remeslo i melkotovarnoe proizvodstvo)" [The small side activities (artisans and production)]. In Ocherki ekonomicheskoi istorii rossii pervoi poloviny XIX veka [Essays on the economic history of Russia during the first half of the nineteenth century], edited by Maria K. Rozhkova, 64-99. Moscow: Nauka, 1959.

—_,"Vymiralo li krepostnoe krest'ianstvo pered reformoi 1861 g.?" [Were serfs really disappearing before the reform of 1861?]. Voprosy istorii 7 (1967): 54-70. 
Sabel, Charles, and Jonathan Zeitlin, eds. World of Possibilities. Cambridge: Cambridge University Press, 1997.

Salais, Robert, Nicolas Bavarez, and Benedicte Reynaud. Linvention du chômage. Paris: PUF, 1986.

Sandhu, Kernial Singh. Indians in Malaya: Immigration and Settlement, 1786-195). Cambridge: Cambridge University Press, 1969.

Saunders, Daniel. Russia in the Age of Reaction and Reform, 1801-1881. London and New York: Longman, 1992.

Say, Jean-Baptiste. Cours d'économie politique. Brussels: Meline, Cans et Compagnie, 1843.

Sbornik Imperatorskogo Russkogo Istoricheskogo Obshchestvo [Collected works of the Imperial Russian historical society], 10 and 41. Saint Petersburg, 1872, 1884.

Scammell, Geoffrey Vaughan. The World Encompassed:The First European Maritime Empires, c. 800-1650. Berkeley: University of California Press, 1981.

Scarr, Derick. Slaving and Slavery in the Indian Ocean. London and New York: Macmillan, 1998.

Schlözer, August Ludwig, and J. M. Schroeck. Histoire universelle, destinée à l'instruction de la jeunesse. The Hague: I. van Cleef, 1800.

Schmiechen, James. Sweated industries and Sweated Labor: The London Clothing Trades, 1860-1914. Urbana, Illinois: University of Illinois Press, 1982.

Schnakenbourg, Christian. Histoire de l'industrie sucrière en Guadeloupe aux XIXe et XXe siècle. Paris: L'Harmattan, 2007.

Schofield, Philip, Catherine Pease-Watkins, and Cyprian Blamires. Rights, Representation, and Reform: Nonsense upon Stilts and Other Writings on the French Revolution. Oxford: Clarendon Press, 2002.

Schrader, Abby. Languages of the Lash: Corporal Punishment and Identity in Imperial Russia. DeKalb: Northern Illinois University Press, 2002.

Schuler, Monica. "The Recruitment of African Indentured Laborers for European Colonies in the Nineteenth Century." In Colonialism and Migration: Indentured Labor before and after Slavery, edited by Pieter C. Emmer, 125-61. Dordrecht, Boston, Lancaster: Martinus Nijhoff, 1986.

Scott, Rebecca. "Defining the Boundaries of Freedom in the World of Cane: Cuba, Brazil, and Louisiana, after Emancipation." American Historical Review 99, 1 (1994): 70-102.

Scott, Rebecca, Thomas Holt, Frederick Cooper, and Aims McGuinness. Societies after Slavery: A Selected Annotated Bibliography of Printed Sources on Cuba, Brazil, British Colonial Africa, South Africa, and the British West Indies. Pittsburgh: University of Pittsburgh Press, 2004.

Scott, Tom, ed. The Peasantries of Europe: From the Fourteenth to the Eighteenth Centuries. London: Longman, 1998.

Seaman, Gary, and Daniel Marks, eds. Rulers from the Steppe: State Formation on the Eurasian Periphery. Los Angeles: Ethnographics Press, 1991.

Sée, Henri. "Les économistes et la question coloniale au XVIII ${ }^{e}$ siècle." Revue d'histoire des colonies 1 (1929): 381-92.

Seeber, Edward D. Anti-Slavery Opinion in France during the Second Half of the Eighteenth Century. Baltimore: Johns Hopkins Press, 1937. 
Semevskii, Vasilii I. Krest'iane v tsarstvovanie Imperatritsy Ekateriny II [The Peasantry under the Reign of Catherine II], vol. 1 (2nd edn, St. Petersburg, 1903 [first published 1881]), Saint Petersburg: tipografiia F. S. Sushchinskago,.

- Krest'ianskii vopros v Rossii v XVIII $i$ pervoi polovine XIX veka [The peasant question in Russia in the eighteenth to the first half of the nineteenth century]. Saint Petersburg: Obshchstevennaia pol'za, 1888.

Semple, Janet. "Foucault and Bentham: A Defence of Panopticism." Utilitas 4, 1 (1992): 105-20.

Seng, Yvonne. "Fugitives and Factotums: Slaves in Early Sixteenth-century Istanbul." Journal of the Economic and Social History of the Orient 39, 2 (1996): 136-69.

Serbina, Ksenia N. Krest'ianskaia zhelezodelatel'naia promyshlennost' tsentral'noi Rossii XVI-pervoi poloviny XIX $v$. [The peasant metallurgic industry in central Russia, from the sixteenth to the first half of the nineteenth century]. Leningrad: Nauka, 1978.

Sewell, William. Gens de métier et révolution. Le langage du travail de l'Ancien régime à 1848. Paris: Aubier, 1983.

Shaw, Alan George Levers. Convicts and the Colonies: A Study of Penal Transportation from Great Britain and Ireland to Australia and Other Parts of the British Empire. London: Faber, 1966.

Shcherbatov, Mikhail M. "Razmotrenie o voprose-mogut li dvoriane zapisyvat'sia v kuptsy?" [Notes on the question: can nobles register as merchants?]. In Neizdannye sochineniia [Unpublished works] Mikhail M. Shcherbatov, 139-58. Moscow: Sotsekgiz, 1935.

Sheptun, Alla. "The German Historical School and Russian Economic Thought." Journal of Economic Studies 32, 4 (2005): 349-74.

Sheriff, Abdul. Slaves, Spices, and Ivory in Zanzibar: Integration of an East African Commercial Empire into the World economy, 1770-1873. London: James Currey, 1987.

Shipova, Elena N. Slovar' turkizmov v russkom iazyke [Dictionary of Turkish into Russian language]. Alma-Ata: Nauka, 1976.

Shvittau, Georg. Trudovaia pomoshch v Rossii [Labor assistance in Russia], 2 vols. Petrograd: tip. A. Kollias', 1915.

Simms, James. "The Crisis in Russian Agriculture at the End of the Nineteenth Century: A Different View.” Slavic Review 36 (Sept. 1977): 377-98.

—. "The Crop Failure of 1891: Soil Exhaustion, Technological Backwardness, and Russia's 'Agrarian Crisis.”' Slavic Review 41 (Summer 1982): 236-50.

SIRIO (Sbornik Imperatorskogo Rossiskogo istoricheskogo obshchestva) (Collection of the Imperial Historical Society) volumes 8, 93, 197 et 134.

Sivkov, Konstantin V. "Istochniki po istorii sel'skogo khoziaistva Evropeiskoi Rossii vo vtoroi polovine XVIII veka" [Sources of the history of agriculture of European Russia during the second half of the eighteenth century]. In Problemy istochnikovedeniia [Problems of sources] VIII, Moscow: Nauka, 1959.

. "Nakazy upraviteliiam XVIII v. kak istochnik dlia istorii sel'skogo khoziaistva v Rossii" [Eighteenth-century estate regulation as a source for the history or rural economy in Russia]. In Sbornik akademika B. D. Grekova ko dniu 70-letiia, Collection of the academician B.D. Grekov for his $70^{\text {th }}$ birthday) 241-46. Moscow: Nauka, 1952. 
Slovar' russkogo iazika XVIII veka [Dictionary of the Russian language of the eighteenth century]. Saint Petersburg: Sorokin, 1998.

Small, Albion. The Cameralists: Pioneers of German Social Policy. New York: Burt Franklin, 1909.

Smith, R. E. F. Peasant Farming in Muscovy. Cambridge: Cambridge University Press, 1977.

Snell, K. D. M. "Agricultural Seasonal Unemployment, the Standard of Living, and Women's Work in the South and East, 1690-1860." The Economic History Review 34, 3 (1981): 407-37.

Sokoloff, Kenneth, and David Dollar. "Agricultural Seasonality and the Organization of Manufacturing in Early Industrial Economies: The Contrast Between England and the United States." The Journal of Economic History 57, 2 (1997): 288-321.

Solomon, Peter, ed. Reforming Justice in Russia, 1864-1994: Power, Culture, and the Limits of Legal Order. Armonk, New York: M.E. Sharpe, 1997.

Sonenscher, Michael. Work and Wages: Natural Law, Politics and the Eighteenth-Century French Trades. Cambridge: Cambridge University Press, 1989.

Stanziani, Alessandro. "Chayanov, Kerblay and les shestdesiatniki: une histoire globale?" Cahiers du monde russe 45, 3-4 (2004): 385-406.

_. "Free Labor-forced Labor: An Uncertain Boundary? The Circulation of Economic Ideas between Russia and Europe from the eighteenth to the Mid-nineteenth Century." Kritika: Explorations in Russian and Eurasian History 9, 1 (2008): 1-27.

- L'économie en revolution. Le cas russe, 1870-1930. Paris: A. Michel,1998.

Stanziani, Alessandro. "The Legal Status of Labor in the Seventeenth to the Nineteenth Century: Russia in a Comparative European Perspective." International Review of Social History, 54 (2009): 359-89.

__. "Les enquêtes orales en Russie, 1861-1914." Annales ESC (2000), 1:219-41. . "Les statistiques des récoltes en Russie, 1905-1928." Histoire et mesure, vol. VII, n.1/2 (1992):73-98.

- Rules of Exchange: French Capitalism in Comparative Perspective, Eighteenth to Twentieth Centuries. Cambridge: Cambridge University Press, 2012.

—. "The Travelling Panopticon: Labor Institutions and Labor Practices in Russia and Britain in the Eighteenth and Nineteenth Centuries." Comparative Studies in Society and History 51, 4 (2009): 715-41.

Steensgaard, Niels. The Asian Trade Revolution of the Seventeenth century: the East India Company and the Decline of the Caravan Trade. Chicago: University of Chicago Press, 1973.

Steinberg, Marc. "Capitalist Development, the Labor Process, and the Law." American Journal of Sociology 109, 2 (2003): 445-95.

Steinfeld, Robert J. Coercion, Contract, and Free Labor in the Nineteenth Century. Cambridge and New York: Cambridge University Press, 2001.

- The Invention of Free Labor: The Employment Relation in English and American Law and Culture, 1350-1870. Chapel Hill: North Carolina University Press, 1991.

Steinmetz, Willibald, ed. Private Law and Social Inequalities in the Industrial Age. Oxford: Oxford University Press, 2000. 
Storch, Heinrich. Cours d'économie politique ou exposition des principes qui déterminent la prospérité des nations, 5 vols. Saint Petersburg: A. Pliushar, 1815.

- Statistische Uebersicht des Statthalterschaften des Russischen Reichs. Riga: bei Johann Friedrich Hartknoch, 1795.

—. Tableau historique et statistique de l'empire de Russie à la fin du 18ème siècle. Paris: Ch. Pougens Imprimeur, 1801.

Strumilin, Sergei. Ocherki ekonomicheskoi istorii Rossii i SSSR [Studies in the economic history of Russia and the USSR]. Moscow: Nauka, 1966.

Struve, Petr. Krepostnoe khoziaistvo. Issledovaniia po ekonomicheskoi istorii rossii $v$ XVIII $i$ XIX vv [The serf economy: studies on the economic history of Russia, eighteenth to nineteenth century]. Saint Petersburg: Sabashikovykh, 1913.

Struys, Jan. Les voyages en Moscovie, en Tatarie, Perse, aux Indes et en plusieurs pays étrangers. Amsterdam: Van Meers, 1688.

Subrahmanyam, Sanjah. The Portuguese Empire in Asia, 1500-1700: A Political and Economic History. New York: Longman, 1993.

Sunderland, Williard. "Peasants on the Move: State Peasant Resettlement in Imperial Russia, 1805-1830.” Russian Review 52, 4 (1993): 472-85.

Tatishchev, Vasilii N. Istoriia rossiiskaia v samykh drevneishikh vremen [History of Russia since the most ancient times]. Moscow: Imperatorskii Moskovskii Universitet, 1768.

- Izbrannye trudy po geografii Rossii [Selected works on the geography of Russia]. Moscow, 1779. Reissued, Moscow: Gosudarstvennoe izdatel'stvo geograficheskoi literatury, 1950.

Teelock, Vijaya. Bitter Sugar: Sugar and Slavery in Nineteenth-century Mauritius. Moka: Mahatma Gandhi Institute, 1998.

Temin, Peter. "Labor Scarcity and the Problem of American Industrial Efficiency in the 1850s." Journal of Economic History XVI (Sept. 1966): 277-98.

Thomas, Pierre. Essai de statistiques de l'île Bourbon. Paris: Bachelier, 1828.

Thompson, Edward P. The Making of the English Working Class. London: Vintage Books, 1963.

Thompson, F. M. L. “The Second Agricultural Revolution, 1815-1880." Economic History Review 21 (1968): 62-77.

Thomson, Janice E. Mercenaries, Pirates, and Sovereign: State-building and Extraterritorial Violence in Early Modern Europe. Princeton: Princeton University Press, 1994.

Tikhonov, Iurii A. Pomeshchic'i krest'iane v rossii: feodal'naia renta v XVII-nachale XVIII $v$ [The private estates' peasants in Russia: the feudal rent in the seventeenth-early eighteenth centuries]. Moscow: Nauka, 1974.

Tilly, Charles. Coercion, Capital, and European States, AD 990-1992. Cambridge: Blackwell, 1990.

Timmer, Charles. "The Turnip, the New Husbandry, and the English Agricultural Evolution." Quaterly Journal of Economics LXXXIII (1969): 375-95.

Tinker, Hugh. A New System of Slavery: The Export of Indian Labor Overseas, 18301920. London: Hansib, 1974.

Toledano, Ehud. The Ottoman Slave Trade and its Suppression. Princeton: Princeton University Press, 1982. 
Slavery and Abolition in the Ottoman Middle East. Seattle and London: University of Washington Press, 1998.

Torre-Schaub, Marta. Essai sur la construction juridique de la catgégorie de marché. Paris: LGDJ, 2002.

Toussaint, Auguste. Histoire de l'ile Maurice. Paris: PUF, 1974.

Tracy, James, ed. The Rise of Merchant Empires: Long-distance Trade in the Early Modern World, 1350-1750. Cambridge: Cambridge University Press, 1990.

Treadgold, Donald. The Great Siberian Migration: Government and Peasant in Resettlement from Emancipation to the First World War. Princeton: Princeton University Press, 1957.

Tribe, Keith. Governing Economy: The Reformation of German Economic Discourse, 1760-1840. Cambridge: Cambridge University Press, 1988.

Troinitskii, Aleksandr'. Krepostnoe naselenie v Rossii po 10 narodnoi perepisi [The Russian serf population according to the tenth census]. Saint Petersburg: Wulf, 1861.

TsSK (Tsentral'nyi Statisticheskii Komitet) (Central Committee of Statistics). Statisticheskiya dannyya o razvodakh i nedeistvitel'nykh brakakh za 1867-1886 [Statistical data on mariages and separations, 1867-1886]. Saint Petersburg, 1893.

Turgot, Anne-Robert-Jacques. Oeuvres et documents le concernant, 5 vols. Edited by Gustave Schelle. Paris: Félix Alcan, 1913-23.

UNICEF. The State of the World's Children. Oxford: Oxford University Press, 1991.

Van der Wee, Herman. "Structural Changes in European Long-distance Trade, and Particularly in the Re-export Trade from South to the North, 1350-1750." In The Rise of Merchant Empires: Long-distance Trade in the Early Modern World, 1350-1750, edited by James Tracy, 14-33. Cambridge: Cambridge University Press, 1990.

Vaughan, Megan. Creating the Creole Island Slavery in Eighteenth Century Mauritius. Durham, London: Duke University Press, 2007.

Veneziani, Bruno. "The Evolution of the Contract of Employment." In The Making of the Labor Law in Europe, edited by Bob Hepple, 31-72. London: Mansell, 1986.

Verlinden, Charles. L'esclavage dans l'Europe médiévale. Bruges: De Temple, 1955.

_. "L'esclavage du sud-est et de l'est européen en Europe orientale à la fin du moyen-âge." Revue historique du sud-est européen XIX (1942): 18-29.

—. "L'origine de sclavus=esclave." Bulletin du Cange XVII (1942): 97-128.

Vernadskaia, Mariia. Sobranie sochinenii [Selected works]. Saint Petersburg: Red. Ekon. Uzak., 1862.

Vernadskii, Vladimir V. Ocherk istorii politicheskoi ekonomii [Studies on the history of political economy]. Saint Petersburg: Red. Ekon. Uzak, 1858.

- Politicheskoe ravnovesie $i$ Angliia [Political equality and England]. Moscow: Univer. tipografiia, 1854.

_. Prospekt politicheskoi ekonomii [Perspectives of political economy]. Saint Petersburg, Red. Ekon. Uzak., 1858.

Vernet, Thomas. "Le commerce des esclaves sur la côte swahilie, 1500-1750." Azania 38 (2003): 69-97.

Vink, Markus. "The World's Oldest Trade: Dutch Slavery in the Indian Ocean in the Seventeenth Century." Journal of World History 14, 2 (2003): 131-77. 
Vladimirskii-Budanov, Mikhail F. Obzor istorii russkogo prava [Summary of the history of Russian law], 6th ed. Kiev: Izdanie knigoprodstva N. Ia. Oglobina, 1909.

Vodarskii, Ia. E. Naselenie Rossii v kontse XVII-nachale XVIII veka [The population of Russia during the seventeenth to the early eighteenth centur]. Moscow: Nauka, 1977.

Voltaire, François-Marie. Correspondance, 107 vols. Edited by Théodore Bersterman. Geneva: Institut et Musée Voltaire, 1953-65.

—. Histoire de l'Empire de Russie sous Pierre le Grand. Paris, 1763. Reissued in Voltaire, Oeuvres historiques. Edited by René Pomeau. Paris: Pléiade, 1957.

Vorontsov, R. “O sposobakh k ispravleniiu sel'skogo domostroitel'estva.” (The methods of calculation in the domestic economy)Trudy IVEO 5 (1765): 1-13.

Voznesenskii, Serguei V. Materialy dlia bibliografii po istorii narodov SSSR XVI$X V I I v v$. [Materials for a bibliography of the history of Soviet people, sixteenth to seventeenth centuries]. Leningrad: Gos. Isz., 1933.

Wagner, William. Marriage, Property, and the Law in Late Imperial Russia. Oxford: Oxford University Press, 1994.

Walicki, Andrzej. The Slavophile Controversy: History of a Conservative Utopia in Nineteenth-century Russia. New York: Oxford University Press, 1975.

Wallerstein, Immanuel. The Modern World-System: Capitalist Agriculture and the Origins of the European World-Economy in the Sixteenth Century. New York, London: Atheneum, 1974, 1976.

Wanquet, Claude. La France et la première abolition de l'esclavage 1794-1802. Paris: Karthala, 1998.

Warriar, Louise, Andrew Robert, and Jennifer Lewis. Surveillance: An Analysis of Jeremy Bentham and Michel Foucault and Their Present-day Relevance, http:// www.mdx.ac.uk/WWW/STUDY/ybenfou.htm.

Watson, Alan. Slave Law in the Americas. Athens, GA: University of Georgia Press, 1989.

Watson, James, ed. Asian and African Systems of Slavery. Berkeley and Los Angeles: University of California Press, 1980.

Webb, Sidney, and Beatrice Webb. The History of Trade Unionism. London: Longmans, 2nd ed. 1911.

Weber, Jacques. "L'émigration indienne des comptoirs, 1828-1861.” Etudes et documents IHPOM 11 (1979): 133-59.

Werrett, Simon. "Potemkin and the Panopticon: Samuel Bentham and the Architecture of Absolutism in Eighteenth-century Russia." The Philosophic Age Almanac 9 (1999): 106-35. (Special issue: The Science of Morality: Jeremy Bentham and Russia)

Wilbur, Chris M. Slavery in China during the Former Han Dynasty. Chicago: Field Museum of Natural History, 1943).

Wilbur, Elvira M. "Was Russian Peasant Agriculture Really That Impoverished? New Evidence from a Case Study from the 'Impoverished Center' at the End of the Nineteenth Century." Journal of Economic History 43 (March 1983): 137-44.

Williams, Brian Glyn. The Crimean Tatars. Leiden: Brill, 2001.

Williams, Eric. Capitalism and Slavery. Chapel Hill: University of Carolina Press, 1944. 
Williamson, Jeffrey. "Why Was British Growth So Slow During the Industrial Revolution?" The Journal of Economic History 44, 3 (1984): 687-712.

Wink, André . Al-Hind: The Making of the Indo-Islamic World: Early Medieval India and the Expansion of Islam, Seventh-Eleventh Centuries, vol. 1. Leiden: Brill 1991.

Wirtschafter, Elise K. Social Identity in Imperial Russia. DeKalb: Northern Illinois University Press, 1997.

Wirtschafter, Elise Kimerling. Structures of Society: Imperial Russia's "People of Various Ranks.” DeKalb: Northern Illinois University Press, 1994.

Wolff, Larry. Inventing Eastern Europe: The Map of Civilization on the Mind of the Enlightenment. Stanford: Stanford University Press, 1994.

Wong-Hee-Kam, Edith. La diaspora chinoise aux Mascareignes: le cas de la Réunion. Paris: L'Harmattan, 1996.

Woods, Donna C. "The Operation of the Masters and Servants Act in the Black Country, 1858-1875." Midland History 7 (1982): 93-115.

Wordie, J. R. "The Chronology of English Enclosure, 1500-1914.” Economic History Review 36 (1983): 483-505.

Wortman, Richard. The Development of a Russian Legal Consciousness. Chicago: University of Chicago Press, 1976.

Wrigley, Eric A. Continuity, Chance, and Change: The Character of the Industrial Revolution in England. Cambridge: Cambridge University Press, 1988.

Young Arthur. Political Essays Concerning the Present State of the British Empire. London: Strahan and Cadell, 1772.

Zaionchkovskii, Pavel Andreevich. Otmena krepostnogo prava v Rossii, 3d ed. Moscow: Izd-vo Kniga, 1968. English translation: The Abolition of Serfdom in Russia. Edited and translated by Susan Wobst. Gulf Breeze, FL: Academic International Press, 1978.

Zakalinskaia, Evgeniia P. Votchinnye khoziaistva Mogiliovskoi gubernii vo vtoroi polovine XVIII veka [Noble estates in the province of Mogilyov during the second half of the eighteenth century]. Mogilyov: Mogilevskii oblast' Kraeved. muzei, 1958.

Zakharova, Lidia G., and J. Bushnell, eds. The Great Reforms in Russia. Bloomington: Indiana University Press, 1994.

Zemon Davis, Nathalie. "A Trade Union in Sixteenth-century France.” Economic History Review 19 (1966): 48-69.

Zurndorfer, Harriet. Change and Continuity in Chinese Local History. Leiden: Brill, 1989.

Zyrianov, Pavel' N. Krest'ianskaia obshchina Evropeiskoi Rossii 1907-1914 9g. [The peasant commune in the European Russia, 1907-1914]. Moscow: Nauka, 1992. 
This open access library edition is supported by Knowledge Unlatched. Not for resale. 


\section{INDEX}

Abkhazian, 76

abolition, 5, 6, 9, 10, 11, 13, 15, 25, 29, 34, $35,36,75,119,140,147,178,179$, $181,184,186,187,188,190,192$, $193,195,197,198,204,208,209,211$

abolitionism, 4

abolitionist movement, 3, 119, 179, 184, 194 abuse, 45, 48, 109, 188, 190, 191, 194

Academy of Sciences, 28, 29

Afghanistan, 5, 78, 79, 80

Africa, African, 1, 2, 12, 13, 14, 24, 33, 63, $64,65,66,68,77,79,88,89,176-78$, 183-86, 192-94, 204, 208, 209, 210, 214

agronomist, 30, 48, 55

Alsace-Lorraine, 160

Anatolia, 87

Antalaotras, 178

Anti-Peonage Act, 209

apprentice, $23,25,31,49,51,56,73,114$, $115,148,150,157,165,175,182$, $183,195,196,205$

apprenticeship, 9, 51, 56, 119, 149, 160, $165,182,196,200 \mathrm{n} 42$.

Arabian Sea, 177, 178

aristocracy, 168, 207

artisan, 7, 71, 74, 79, 114-17, 130, 136, $160,176,183,188,193,208$

Astrakhan, 78, 79, 81, 82, 83, 86

Athens, 49

Australia, 179, 180, 210

backwardness, $2,3,4,8,23,24,64,88,113$, $117,118,129,136,139,140$

bad harvest, $55,74,132$

bailiffs, 8 , 46-48

Balkans, 75, 89

barshchina, 8, 29, 129-33

Bashkir, 81, 86

Bentham, Jeremy, 4, 42-56, 148, 149, 159

Bentham, Samuel, 42-56 black earth, 103, 123, 127, 135

Black Sea, 5, 43, 76, 77, 81, 84, 87, 90

Bohemia, 128, 137

Borneo, 209

Brandenburg, 30, 137

British Guyana, 210

Brittany, 181

broker, 63

Buddhism, 64

Buddhist, 78

Bukhara, 79, 86, 90

Bulgarian, 76

Burma, 209

Byzantine Empire, 67, 76, 77, 91

Caffa, 67, 76, 77, 87, 89

cameralism, 28, 29, 30

Canada, 181, 183, 193, 211

Canary Island, 77

capital, 133, 134, 152-54, 158, 159, 165, $166,167,179,183,197,207,208,212$

capitalism, 7, 32, 64, 127, 139, 140, 148, $165,168,196,211$

capitalist, 2, 14, 15, 31, 36, 113, 140, 148, 167

captive, $5,49,63,64,66,67,68,70,75-88$, $89,91,92,151$

caravan trade, $77,78,79,86,90,91$

Caribbean, 179, 180, 189

Caspian Sea, 76, 86

Catalonia, 76

Catherine II, 4, 25, 27, 28, 42, 43, 44, 46, $48,52,53,106,108,114,117,130$

Caucasus, the, 78, 82, 87, 88, 90, 106

cavalry, 69, 71, 75, 102

cavalrymen, 75,102

census, 139, 166, 184, 213

Central Asia, 1, 5, 61, 63, 64, 67, 68, 75-91, 208

central industrial region(s) (of Russia), 133, 135 
certificate, 116, 117, 118, 174n99, 116, 117

chamber of commerce, 161

Châtillon-sur-Seine, 163

Cher, 163

children, child labor, $11,32,33,34,49,50$, $65,66,68,70,72,73,74,85,87,114$, $132,139,148,150,153,157,177$, $181,187,197,207,213$

China, $4,5,64,65,72,78,83,86,93$, $93 \mathrm{n} 17,177,186,209$

Christian, 32, 33, 64, 87

Christian Socialism, 31, 32

Christianity, 64, 85

Circassian, 76, 87, 90

citizen, 117

city-state, 79,81

Civil War, U.S., 119

clan, 63,99 n 125

cloth, 86, 131, 134, 135

code (legal), 30, 52, 69, 72, 162

collateral, 177

colonial. See colony

colonization, 9, 14, 77, 82, 105

colony, 1, 2, 5, 9, 10, 11, 12, 13, 14, 15, 23, $24,25,26,29,31,54,55,56,65,67$, $72,86,106,118,119,147,148,151$, $159,165,175,176,177-98,204,208$, $210,211,213,214$

common lands, 157, 212

commune. See peasant commune

Comoros Islands, 187

compensation, $6,73,85,105,110,112$, $162,163,154,168,185,205,211$

competition, $6,7,73,76,83,88,104,114$, $115,130,131,132,135,140,152$, $156,158,167,168,185,186,189$, $191,193,195,197,207$

concentration, 133, 208, 212

concubine, 177, 178

Condillac, Bennot-Etienne, abbé de, 26 conflicts, 47, 73, 103, 104, 106, 114, $116-19,130,132,135,149,156,187$, 195,213

Congo, 187

Constantinople, 76, 77

convict, 156, 157, 179-81, 190

coolies, 190, 193, 195

copper, 43

corporal punishment, 50, 55, 189, 190, 192

Cossack, 43, 84, 87, 106, 212

cotton, 86, 91, 131, 134, 153, 178, 208 court, 47, 57n2, 73, 89, 101, 102, 103, 106, $107,110,112-19,130,156,157,160$, $168,188,189,190,191,194,195$, 206,213

craftsmen, 43, 71, 84, 130, 134, 135, 138, 207

Crimea, 43, 67, 75, 76, 81, 84, 87, 90

Crimean khanate, 81,82

criminal law, 9, 50, 51, 56, 73, 114, 148, $149,151,155,157-60,164,165,169$, $181,187,192,195,198,205,221$

Cuba, 210

Custine, Astolphe de, 33

customs, 33, 89, 90, 161-63, 169

customary law, 15, 30, 47, 72, 132, 161-63, 177

debt, $69,70,71,72,75,103,107,111$, $133,136,174$ n99, 183, 189, 192

debt bondage, 11, 63, 64, 66, 69, 71, 74, $147,176,177,194,197,210$

Demidov estate, 130-31

desertion, 182, 195

Diderot, Denis, 3, 25-27

discipline, $6,36,43-45,53,54,149,150$, $155,156,169$

dispute, 47, 69, 70, 73, 103, 106, 107, 118, $157,160,162,163,164,187,188$

division of labor, $2,29,32,35,52,54,78$, 113

domestic, 1, 11, 29, 32, 49, 64, 70, 73, 74, $75,76,79,84,89,136,151,153$, 160-64, 174n92, 175, 176, 178, 181, $185,192,193,195,196,198$

drought, 33

Dutch, 178, 193, 209

East Africa, 177, 178, 184, 187, 193

East-Elbian, 137

education, 27, 28, 34, 51, 53, 109

Egypt, 76, 77, 87, 89, 178

emancipation, $11,14,34,35,45,56,107$, $111,112,118,119,133,135,140$, 147,204

Employers and Workmen Act, 205

enclosure, 32, 50, 148, 167, 212

enforcement (of rules), 31, 73, 104, 105, $115,136,155-59,180,184,185,187$, 194, 195

English Muscovy Company, 81

estate, $4,5,6,7,8,9,12,14,15,30,31-33$, $42-47,50,52-56,57 \mathrm{n} 2,58 \mathrm{n} 29,69$, 
70, 73, 102-20, 125n96, 127-40, 142n39, 142n43, 143n52, 159, 165, $167-69,179,186,188,189,191,194$, 219

Ethiopia, 178

export: products, $8,83,90,91,129,131$, $175,178,179$; slave, $53,78,80,87$, 90,210

fairs, 86, 129

family, 1, 32, 72, 102, 132, 135, 140, 150, $155,159,167,205,213$

famine, 102, 139, 194, 211

Fergana Valley, 86

Flanders, 128

French Revolution, 2, 3, 10, 14, 32, 35, 160, $168,196,204$

frontier, 9, 86, 88, 209

Gabon, 187

Genoa, 67, 76, 77, 78, 89, 90, 91

Golden Horde, 78, 80, 99n125

grain, 25, 76, 129, 133, 135, 154, 211

Greek, 64, 76

Guiana, 180, 210

guild, $3,15,23,24,25,26,29,31,36,106$, $114,115,116,117,125 \mathrm{n} 103,128$, $137,148,159,160,205$

harem, 76,87

harvest, $48,55,74,102,129,132,135$, $137,153-59,161,166,207$

Hejaz, 117

horse, horse trade, $53,78,79,82,86,91$, 92,111

household, 69, 74, 89, 114, 127, 131, 135, $150,153,163,166,168,177,212$

Imerina Empire, 118

incentive, $29,31,34,36,48,112,134,138$, 156

income, 8, 77, 103, 139, 129, 130, 131, $132,134,138,139,153,166,183$, $207,211,212,213$

India, $5,11,13,14,15,64,65,72,78-80$, $83,86,88,90,91,92,175-96,209$, 210

Indian Ocean, 1, 11, 12, 175-96, 208, 209. See also Arabian Sea

Industrial Revolution, 2, 7, 10, 12, 13, 14, $148,151,153-54,158,159,167,168$, 206, 207 industrious revolution, 153

Inner Asia, 4, 5, 9, 11, 12, 14, 80, 89, 90, $91,92,115$

insubordination, 50, 151, 188, 194

intensification, 1, 12, 132, 136, 152, 154, $158,165,166,167,169,177,197$

Iran, $75,76,78,79,80,83,86,90,91$

Irbit, 86

Islam, 12, 64, 72, 77, 78, 87, 88, 177, 178, 187

Islamic law, 72, 79, 85

Istanbul, 79, 81, 82, 92

Italy, 75, 79, 89, 128

Ivan IV, 66, 102

Ivanovo, 129, 134

IVEO (Free Economic Imperial Society), 47

Jamaica, 189

Japanese, 192, 210, 211

journeymen, 9, 148, 151, 162-63, 182, 205

justices of the peace, 161, 162, 164, 185, 189

Kalmyk, 81, 82, 84, 87

Karakalpak, 87

Karany, 178

Kazakh, 78, 81, 86, 87

Kazan, 81, 83, 117

khan, 76,81

khanate, 75, 80-84, 86, 91, 99n125

Khiva, 79

Kilia, 76

Kilwa, 118

Kokand, 86

Kostroma, 134

Kuban, 87

kul, 177

Kyrgyz, 78

labor-intensification. See intensification labor mobility, 5, 6, 10, 15, 72, 102, 105, 136, 137, 138, 140, 151, 167, 169. See also migration, peasant mobility

labor service, 1, 6, 9, 10, 11, 43, 47, 49, 69, $70,71,72,74,75,76,85,102,104$, $106,107,110,114,119,120,127$, $128,131,132,133,135,137,140$, $150,151,158,159,160-65,175,179$, $181,182,183,186,188,189,196$, 198,213

labor shortage, 156, 158, 167, 186

Lancashire, 15, 155, 169 
landlord, 1, 2, 6, 8, 30, 45, 47, 55, 103, 104, $111,119,127,129-35,138,140,167$, 212,213

Latin America, 65, 128

linen, 129,131

Lithuania, 45, 78, 81, 82, 83, 84, 85, 87, 137

livestock, 154, 165

living condition, 49, 51, 179, 186, 190, 193, $196,197,211$

livret ouvrier, 164, 187, 189

loan, $72,107,114,136,212$

loom, 43, 134, 136, 155

luxury, $8,77,78,86$

Madagascar, 178, 184, 186, 187, 193

Maghreb, 177

Malaya, 189

Mamluk, 68, 76

management, 4, 29, 30, 35, 42-59, 207

Manchuria, 208, 209

manumission. See emancipation

Marne, 163

marriage, 6, 150, 192

Marx, Karl, 32

Master and Servant Acts, 9, 11, 13, 56, $148-59,167,192,194,204,205$

Maurocastro, 76

Mayotte, 187

mechanization, 13, 153, 154, 165, 166, 197, $205,208,213$

medical, 180, 189

Mediterranean, 5, 12, 75, 77, 80, 83, 88, 91,160

Melanesia, 189

merchant, $6,8,38,76-79,82,83,86,91$, $103,104,106,107,108,114,115$, $116,117,118,129,130,131,132$, $133,134,136,148,167,168,177$, $178,179,182$

metal, 131, 153

Middle East, 76, 77

migration, $6,11,13,105,117,135,153$, $164,178,179,181,183,188,193$, $194,197,208-10,213,214$

military colonies, 55

mine, 53, 76, 110, 152, 209

mogul, 117

mobility. See labor mobility

money, 108, 131, 162, 190

Mongol, 64, 66, 67, 75, 76, 78, 81, 84, 91

Morocco, 117 mortality, 28, 132, 139, 211

mortgage, 110, 111

Moscow, 28, 35, 53, 81, 82, 83, 84, 85, 86, $89,95,101,116,129,130,131,134$, 212

Mozambique, 178, 184, 186, 187

Muhammad the Conqueror, 77

Muslim, 68, 78, 79, 80, 82, 85, 87, 117, 178,181

Netherlands, 77, 128, 153

New Caledonia, 180

Nizhegorod, 130, 218

Nizhnyi-Novgorod, 66, 74, 81, 115, 117, $130,131,134$

noble, nobility, $8,28,30,33,34,36,45$, $46,47,48,54,55,68,70,74,102-12$, $116-18,129-34$

Nogays, $81,82,84,85,87$

nomad, 64, 66, 67, 77, 78, 80-83, 88

Nord, 163

Normandy, 181, 182

Omanis, 177,178

Orenburg, 86

Orientalism, 3

Ottoman Empire, 5, 33, 43, 65, 67, 76, 78, $79,80-84,85,87,88,90,91,92,210$

passport, 116, 134, 136, 213

Pavlovo, 130, 135

pawnship, 64, 66

peasant commune, $9,35,47,119,132,135$, $136,137,211,212,213$

peasant mobility, 6, 102, 103, 107, 117, 118, 122n32, 131. See also labor mobility peasant-worker, 113, 130, 131, 132, 135, $155,159,165,168,205,208,212$

Persia, 5, 78, 82, 86, 90, 93nl7

Persian Gulf, 117, 177

Persian merchants, 78, 79, 81, 83, 86, 90, 91

Peru, 210

Peter the Great, $24,27,68,69,74,75,89$, $95 \mathrm{n} 51$

physiocrat, 24, 25, 26, 27, 28, 34

Picardy, 160

piecework, 163, 206

pieceworker, 161, 162, 163

pirate, $64,66,83,88$

plantation, 35, 176, 177, 178, 179, 183, $185,186,188,189,192,193,194$, $195,197,209$ 
planter, 179, 186, 194, 197

Poland, 23, 43, 77, 81, 82, 137, 167

Polanyi, Karl, 148

police, $26,46,53,58 \mathrm{n} 26,73,115,118$,

$156,188,190$

political arithmetic, 28, 29, 39n 26

pomest'e, 69, 102, 142n24

Pontic steppe, 81

poor, 4, 29, 50-55, 155, 158, 164

poor laws, 4, 42, 50-55, 148-50, 156, 157, $159,205,206,218$

population, $1,2,5,28,43,46,66,71,72$, $74,76,87,89,102,103,104-8,111$, $112,114,116,117,129,132,134$, $137,139,149,156,180,193,196$, $205,208-13$

Portugal, 77, 187

Portuguese, 77, 178, 179, 187, 193, 210

Potemkin, Grigorii, 4, 16n9, 42, 43, 44, 46, $47,48,52$

price, $102,114,117,128,129,133,136$, $152,162,165,166,167,179,184$, $191,194,208$

productivity, $6,32,36,52,53,54,55,127$, $132,136,138,139,166,211,212$

profit, 54,150

prosecution, $149,150,156,157,158,195$, 205

proto-industry, $1,8,30,48,55,117,120$, $128,129,130,131,132,133,134$, $135,136,137,138,139,140,154$, $165,166,167,168,169,196,213$ prud'homme(s), 160, 162, 168

Prussia, 28, 31, 45, 46, 137, 166, 167, 168 public order, 51, 156, 189, 195, 207

Pugachev's revolt, 25, 46, 48

putting-out, 134, 136, 152, 154, 156, 157, 166,168

quitrent, $6,29,48,127-44$

race, $34,51,118$

rank, $27,30,71,73,84,90,106,109,114$, 117,150

ransom, 63, 75, 82, 84, 85, 87

Raynal, Guillaume-Thomas, 3, 26, 27, $38 \mathrm{n} 20$

reciprocity, $65,163,210$

Red Sea, 90

redemption, 111, 187. See also emancipation refugee, 87

relief, 50, 51, 53, 149, 159. See also poor remuneration, 48, 173n92, 207

resistance, 30, 186, 190, 191

revolution, 26-35, 120, 139, 148, 151, 160-62, 164, 167, 168, 196, 197, 208, 211. See also French Revolution, Industrial Revolution

rights, $2,6,8,10,11,12,13,49,52,65,68$, $71,73,88,108,112,114,140,150$, $169,185,187,188,191,192,196$, $197,198,204,207,210$

riot, $26,29,48,55,157,185$

Rome, 63,75

Rumanians, 76

runaway, 9, 51, 103-6, 130, 148, 165, 185, 195

Ruthenians, 76

sabotage, 150, 157

Safavid, 79, 80, 91, 93n17

Sahara, 90, 177, 178

sailor, 175, 176, 182

Saint-Petersburg, 28, 29, 33, 43, 53, 134

Samarkand, 78, 79

sanction, 10, 50, 51, 56, 73, 104, 151, 152, $155,158,159,205$

Saracens, 76

Say, Jean-Baptiste, 30, 32, 35, 49, 54

seamen, 71, 83, 93, 151, 178

seasonal, 135, 136, 137, 138, 152, 153, 154, $155,156,157,158,161,162,163$, $166,167,169,206,207,208,213$

Seigniorial, 8, 45, 46, 106, 118, 128, 133, 137,139

Senegal, 187

servant in husbandry, $72,152,155,160$, $161,162,166,173 n 92,188$

service. See labor service

settlement, 55, 104, 105, 106, 139, 180, $181,189,209$

sharia law, 72

Sheremetevs, 47, 58n29, 84, 125n103, 130, $135,142 \mathrm{n} 24, \mathrm{n} 31, \mathrm{n} 39,143 \mathrm{n} 49,219$

Siberia, 9, 53, 54, 81, 84, 86, 87, 105, 208, 209,213

silk, 81, 83, 86, 131, 157

silk road, 5, 75, 91

silver, 84

skill, 4, 42, 43, 44, 48, 56, 78, 79, 136, 151, $153,154,155,158,207,210$

slave trade, $5,11,67,75,76,80,82,84$, $87,89,90,91,92,177,178,179,184$, $187,192,208$ 
Slavery Chancellery, 85

Smith, Adam, 25, 29, 31, 35, 37, 49, 51, 54, 148,168

Smolensk, 85, 117, 218

socialism, 31, 32

soldier, 11, 46, 65, 71, 105, 178, 185

Spain, 76, 77

speculator, 111

spice, 81

standard of living, 132

state peasant, 108-11, 134

statute of artificers, 148, 205

statute of laborers, 150

steam, 152, 153, 199n7, 208

succession, 111

sugar, 178, 191, 192, 193, 197, 208

sultan, $72,76,79,81,82,187,193$

supervision, 8, 44, 46, 50, 51, 52, 54, 127

Surinam, 189

surveillance, 4, 16n7, 42, 44, 47, 50, 52, 53, $54,57 \mathrm{nl}, 180,187,194$

Swahili, 176, 178, 193

Tana, 76,89

Tatar, $5,68,76,77,81,84,87,90$

Tashkent, 78, 86

tax, 5, 15, 46, 47, 71, 74, 84, 87, 103, 108, $110,112,114,116,117,135,147,168$

tenant, 182

Thailand, 189

Thirteen Years War (1654-67), 85

time of labor, 132, 164

trade union, $2,13,167,168,185,188$, 205-9

transportation, $13,87,90,130,135,153$, $179,180,181,184,189,206,208$

Trinidad, 210

Tripoli, 67

Tula, 115, 131, 14ln19, 219

Turan, 79

Turgot, Robert Jacques, 24, 25, 37n9
Turkistan, 84

Turkmen, 89

Tver', 83

Ukraine, 84, 87, 90, 105

unemployment, 155, 163, 205, 206

unfair competition, 104, 156, 167, 185, 189, $191,193,197$

Urals, 86, 105, 131

urbanization, 53, 117, 140, 166, 167, 208, 212

Utopia, 31, 32, 36, 52, 54, 56

Uzbek, 78, 79, 80, 86

Venice, 67, 76, 77, 78, 83, 89, 90, 91

Vladimir (province), 81, 134, 212

Volga, 81, 82, 86, 87, 105

Voltaire, François-Marie, 24, 25, 27

Voronezh, 111, 115

war, $53,54,55,64,75-80,82,85$

war captive, $5,63,64,66,67,68,75-80,82$, $85,87,89,91,92,151$

warfare, $5,64,71,75-92$

weavers, $131,134,136$

Webb, Beatrice and Sidney, 205

welfare state, 2, 13, 205, 207

West Indies, 176, 181, 183

woman, women, $11,33,34,49,74,76,87$, $148,150,153,154,177,187,207$, 213

worker booklet, 164

workhouse, 50, 51, 53, 149-50, 180, 188

Workmen's Compensation Act, 205

Xinjiang, 86

Yaik River, 81

Young, Arthur, 33

Zanzibar, 118 